\title{
THE DESIGN OF A NOVEL, ENVIRONMENTALLY IMPROVED, INDUSTRIAL COTTON PRE-TREATMENT PROCESS
}




\section{Dissertation Committee}

Chairman:

prof.dr. F. Eising, University of Twente, the Netherlands

Secretary:

prof. dr. F. Eising, University of Twente, the Netherlands

Promotors:

prof. dr. ir. M.M.C.G. Warmoeskerken, University of Twente, the Netherlands

prof. dr. ir. W.P.M. van Swaaij, University of Twente, the Netherlands

Members:

prof. dr. ir. R. Akkerman, University of Twente, the Netherlands

ir. G.J. Brinks, Saxion Universities of Applied Science, the Netherlands

dr. ir. W. Coerver, Vlisco BV, the Netherlands

dr. ir. V.A. Nierstrasz, Ghent University, Belgium

prof. dr. G. Rovero, Politecnico di Torino, Italy

This work was financially supported by Saxion University of Applied Science the Netherlands and EFSM Foundation.

G.H. Bouwhuis

The design of a novel, environmentally improved, industrial cotton pre-treatment process.

Thesis, University of Twente, the Netherlands

ISBN 978-90-365-3153-5

Printer: Wohrmann Print Service, the Netherlands

Cover design: Petra Grevinga and Gerhard Herman Bouwhuis

(C) G.H. Bouwhuis, Enschede, 2011

No part of this work may be reproduced by print, photocopy or any other means without the permission in writing from the author. 


\title{
THE DESIGN OF A NOVEL, ENVIRONMENTALLY IMPROVED, INDUSTRIAL COTTON PRE-TREATMENT PROCESS
}

\author{
PROEFSCHRIFT
}

ter verkrijging van

de graad van doctor aan de Universiteit Twente, op gezag van de rector magnificus prof. dr. H. Brinksma, volgens besluit van het College van Promoties, in het openbaar te verdedigen op donderdag 10 maart 2011 om 14.45 uur.

door

Gerhard Herman Bouwhuis geboren op 2 maart 1955

te Enschede, Nederland 
Dit proefschrift is goedgekeurd door de promotoren:

Prof. dr. ir. M.M.C.G. Warmoeskerken

Prof. dr. ir. W.P.M. van Swaaij 
To my wife and daughters... 


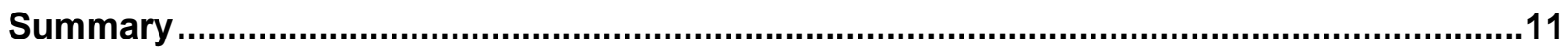

Samenvatting

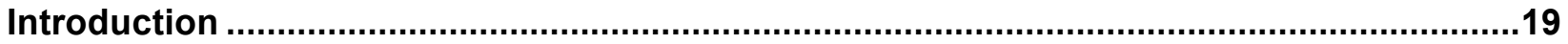

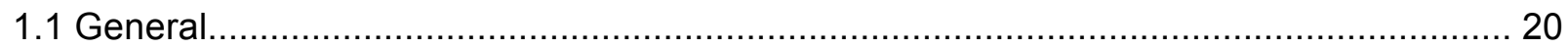

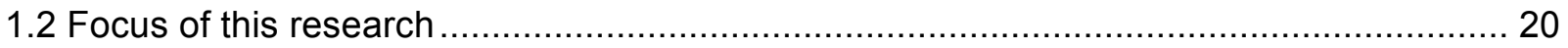

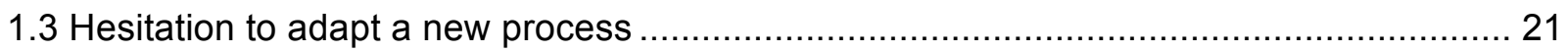

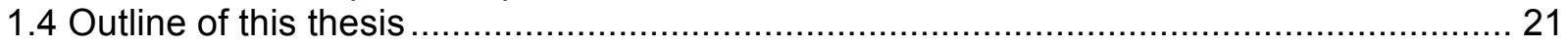

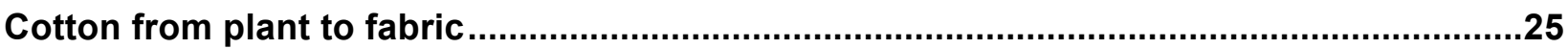

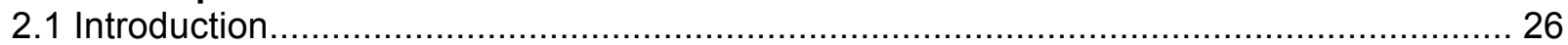

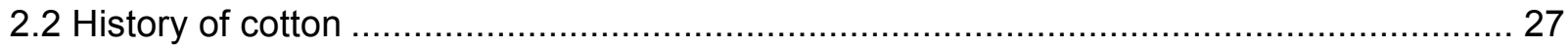

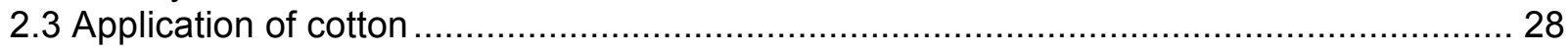

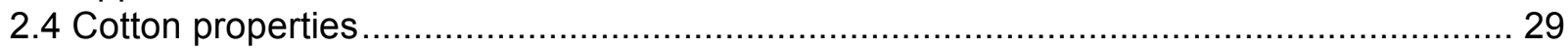

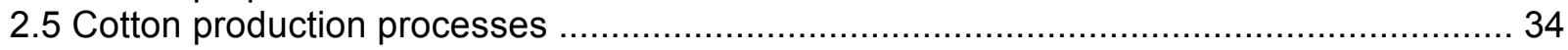

2.5.1 Structuring processes................................................................................. 34

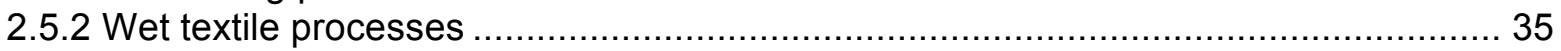

2.6 Pre-treatment installed base ....................................................................... 40

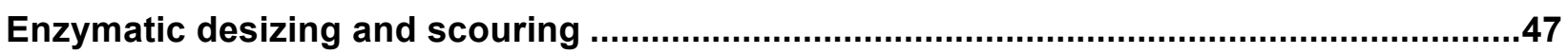

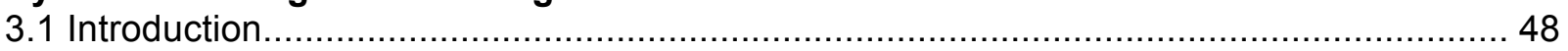

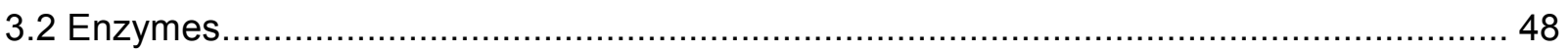

3.3 Candidate enzymes in pre-treatment processes for cotton ......................................... 51

3.4 Enzyme selection for one step processing ........................................................ 57

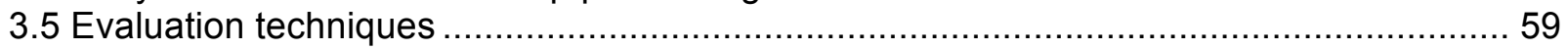

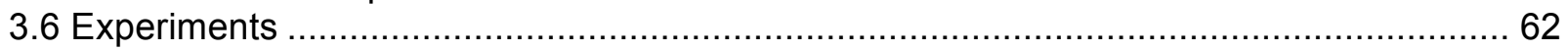

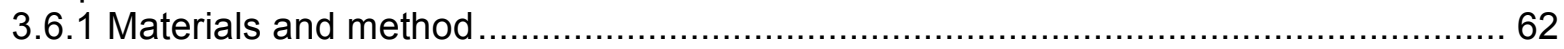

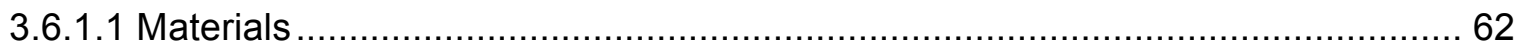

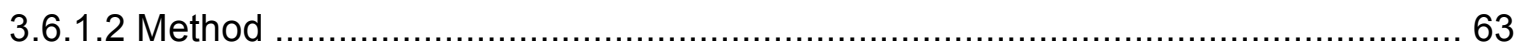

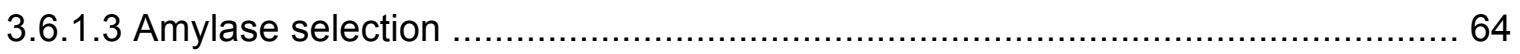

3.6.1.4 Exploration of the enzyme cocktail in pad-batch and continuous treatment ....... 64

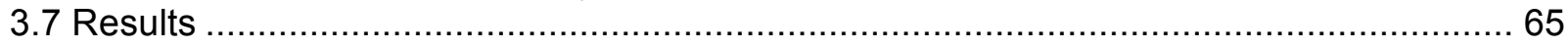

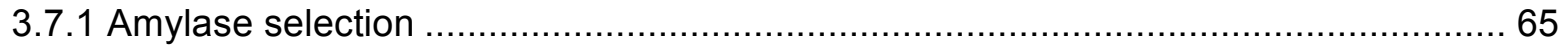

3.7.2 Compatibility of Baylase RL 987 with other desizing and scouring agents ................ 65

3.7.3 Results for desizing and bio-scouring in pad batch processing .............................. 66

3.7.4 Results for desizing and bio-scouring in continuous processing ............................. 70

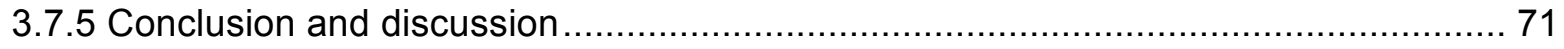

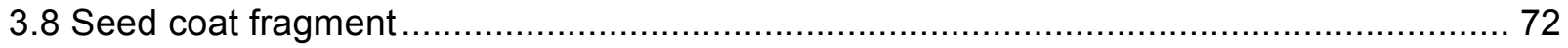

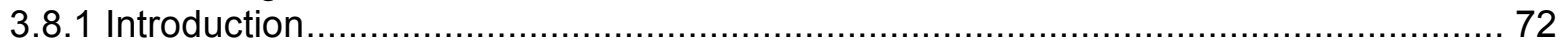

3.8.2 Morphology of seed coat fragments ............................................................... 75

3.8.3 Options for seed coat fragment removal .......................................................... 77

3.8.4 Evaluation technique for seed coat removal performance ................................... 77

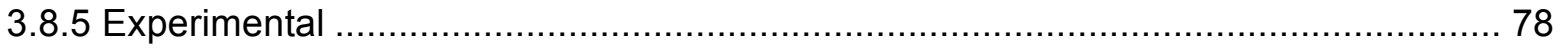

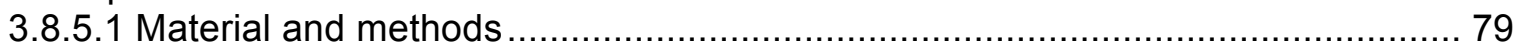

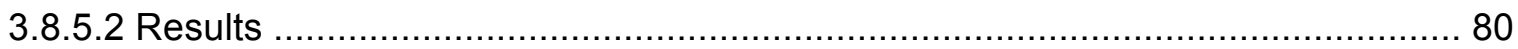

3.8.5.3 Conclusion on enzymatic SCF removal ……….................................. 82

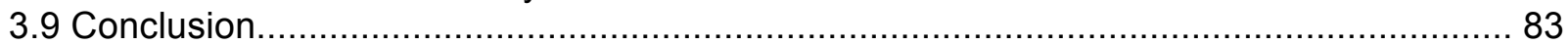




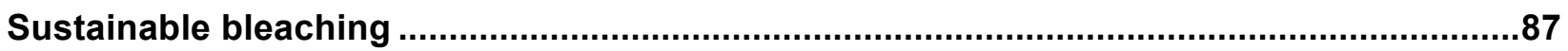

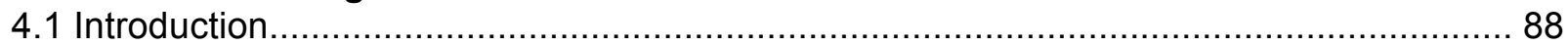

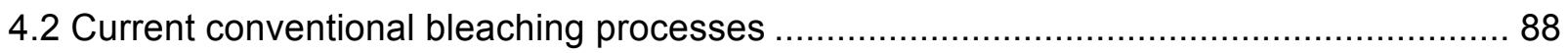

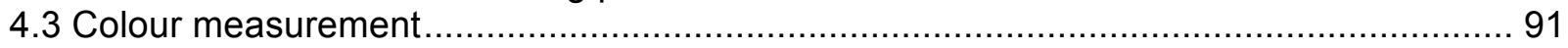

4.4 New developments in the bleaching process ……….................................................. 93

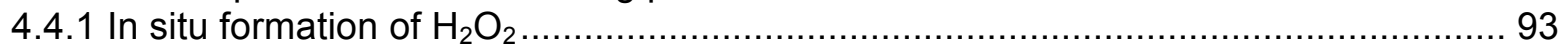

4.4.2. Bleaching with in situ formed peraceticacid .................................................. 94

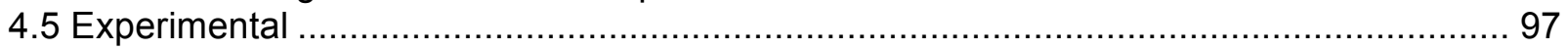

4.5.1 Experimental set up, materials and method ……............................................. 98

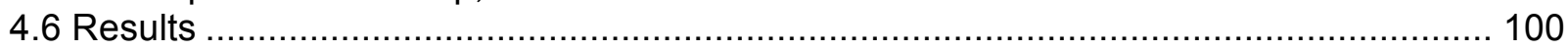

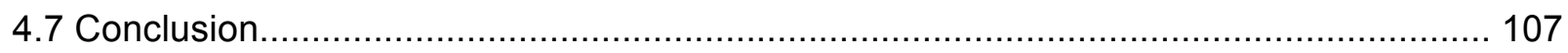

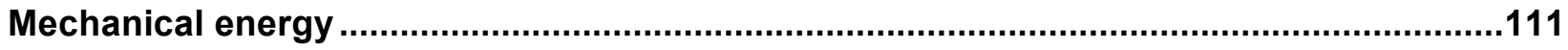

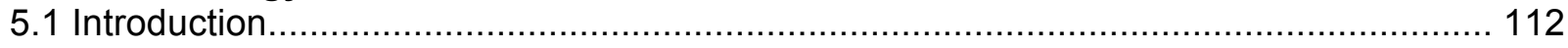

5.2 Current processes for the pre-treatment of cotton ................................................... 112

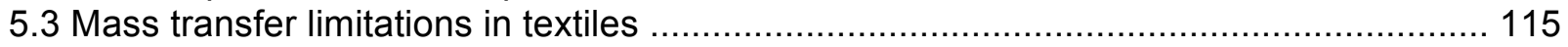

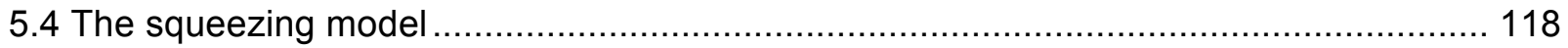

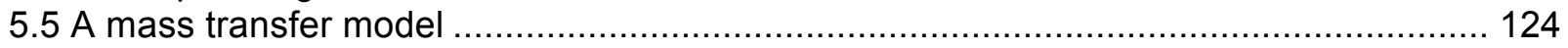

5.6 Adsorption limitation in textile pores................................................................ 128

5.7 Modelling the adsorption limitation in textile pores.................................................... 135

5.8 The application of ultrasound …………………................................................... 139

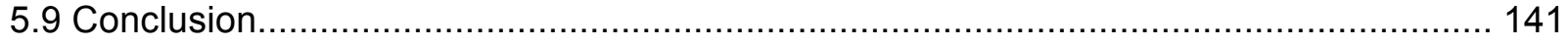

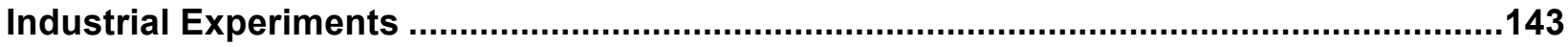

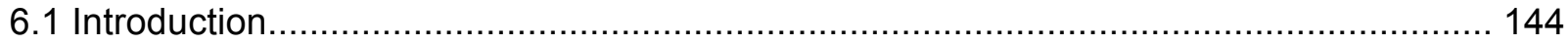

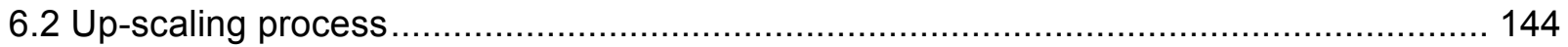

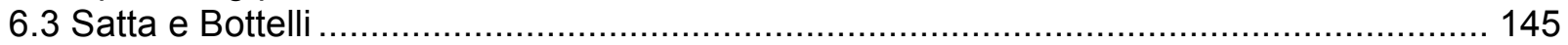

6.3.1 Chemicals and conditions in industrial trials ............................................... 147

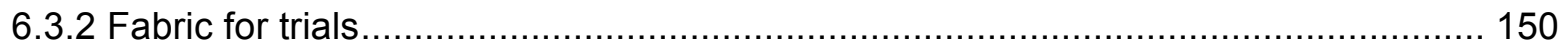

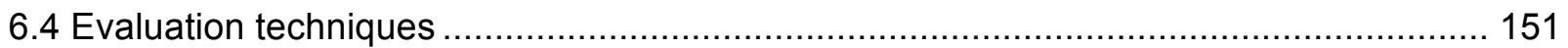

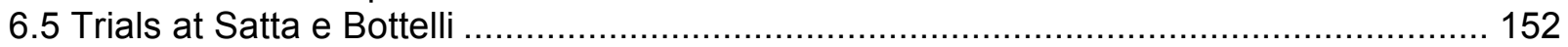

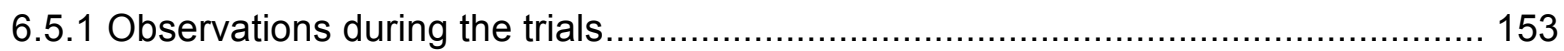

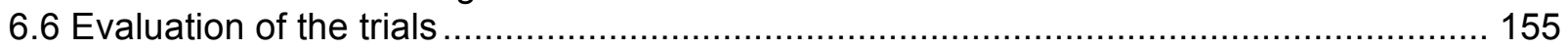

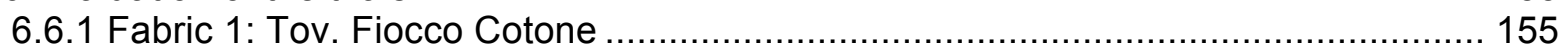

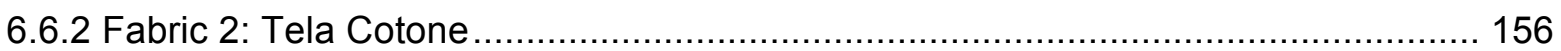

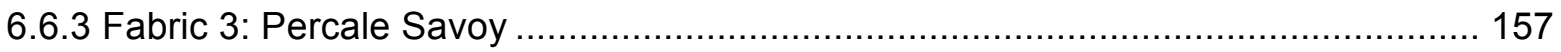

6.6.4 Overall performance of the new pre-treatment process after the first trials ............ 159

6.6.5 Evaluation of the wastewater samples ........................................................... 159

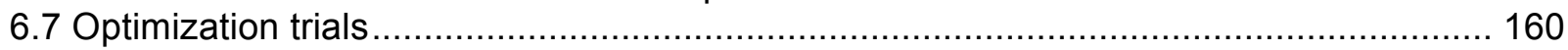

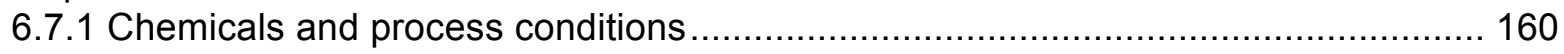

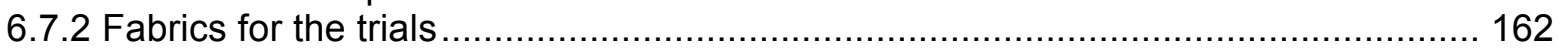

6.7.3 Observations and adjustments during the trials ............................................. 162

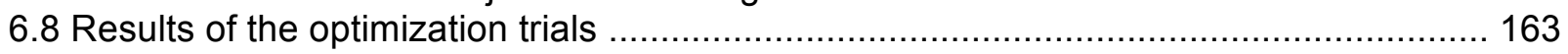

6.8.1 Fabric 1: Tela Cotone ............................................................................. 163

6.8.2 Fabric 2: Percale ...................................................................................... 164

6.8.3 Standard desizing with new developed 'process conditions and bleaching agents' 165

6.8.4 Overall performance of the new pre-treatment process ......................................... 166

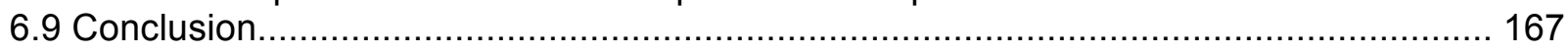




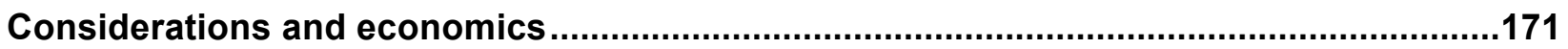

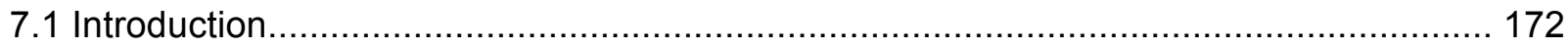

7.2 The importance of the value chain and the research funnel .................................... 173

7.3 Financial evaluation on cost reduction of water, energy and wastewater ................... 175

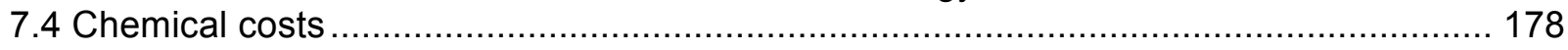

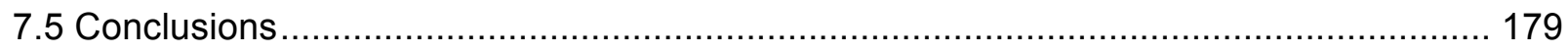

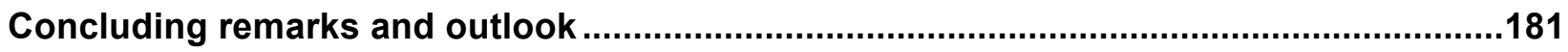

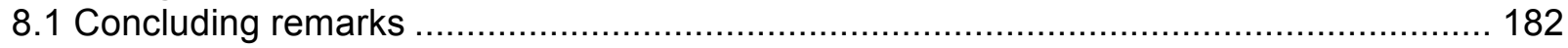

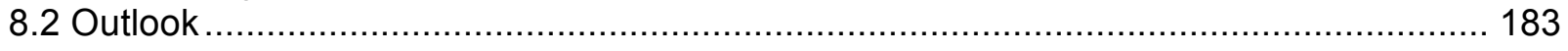

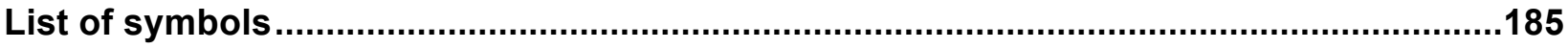

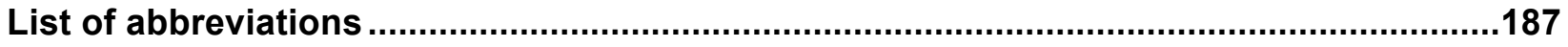

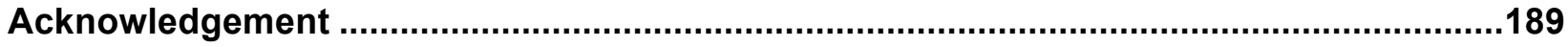

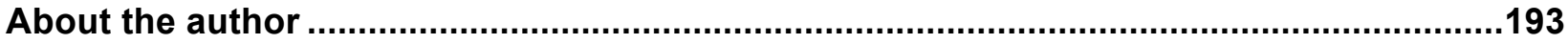



The scope of this thesis is the development of a new industrial applicable pre-treatment process for cotton based on catalysis. The pre-treatment generally consists of desizing, scouring and bleaching. These processes can be continuous or batch wise. Advances in the science of biocatalytic pre-treatment of cotton and catalytic bleaching formed the scientific basis for this work. The work of Agrawal on enzymes for bio-scouring and of Topalovic on catalytic bleaching led to the conclusion that reduced reaction temperatures for the pre-treatment processes of cotton are possible. A second reason for the present work is a persistent and strong pressure on the industry to implement 'more sustainable' and environmental friendlier processes.

It was clear that for the industrial implementation of the newly developed process it would be necessary to 'translate' the academic knowledge based on the catalysts, into a process at conditions that are applicable in textile industry.

Previous experiences learned that the transition from academic knowledge into industrial applicable processes often failed. This is caused by lack of experience of university researchers with industrial product and process development as well as a lack of awareness of industrial developers of academic research. This is especially evident for the so-called Small and Medium Enterprises (SME's). To overcome this gap a first step was to organize collaboration between academic institutes and industries. The basis for the collaboration was the prospect of this work for benefits for all parties involved.

A rational approach has been adopted by first gathering knowledge about the properties and morphology of cotton and the know how on the conventional pre-treatment process. To be able to understand the conventional processes it was necessary not only to explore the chemical and physical aspects but also to evaluate the process conditions and equipment that are used. This information has been the basis for the present lab research on combined bio-catalytic desizing and scouring as well as catalytic bleaching. For the measurement of the performance of the treatments and the process steps, the performance indicators have been evaluated and selected. Here the choice has been made to use industrially known and accepted performance indicators.

For the new bio-catalytic pre-treatment an enzyme cocktail, consisting of amylase, cutinase and pectinase has been developed. The process conditions in the enzyme cocktail tests have been explored reflecting different pre-treatment equipment as they are used in practice and for their different operation conditions. The exploration showed that combined bio-catalytic desizing and scouring seemed attractive for industrial application, with major reduction of the reaction and the rinsing temperatures, leading to several advantages. The performance of this treatment, when compared with the existing industrial treatment showed that the quality of the treated fabric was comparable or better than the present industrial standard, while concentrations enzymes in the cocktail have not yet been fully optimized.

To explore the application of a manganese catalyst in the bleaching step of the pre-treatment process the fabrics were treated with the enzyme cocktail prior to the bleaching. It has been 
decided not to use conventional pre-treatment processes because in that case the combined desizing and scouring step would not be integrated in the newly developed process. To explore catalytic bleaching it has been tried to mimic the existing industrial processes where possible. The use of the catalyst at $100^{\circ} \mathrm{C}$, as occurs in a conventional steamer, leads to decomposition of the catalyst and thus no bleach activation occurs. This led to the conclusion that catalytic bleaching is not possible in present steamers nor at low temperature. This latter fact is caused by equipment restrictions, which are not easily overcome without important investments. So it has been decided to explore the bleaching process by simple batch experiments in a beakerglass. From these experiments it has been concluded that catalytic bleaching is only possible in discontinuous equipment, where the fabric is treated in an aqueous environment at low temperature. A special result of the experiments on bleaching was that the bio-catalytic treating steps allows a reduction of the concentration sodiumhydroxide in the bleaching step. In conventional treatments sodiumhydroxide is needed to saponify the waxy layer and to degrade the pectin in the primary wall of cotton. As this has already been achieved in the bio-catalytic treatment step it is not necessary anymore to add sodiumhydroxide for wax and pectin removal to the bleaching liquor.

To explore the importance of mass transfer in bio-catalytic wet textile processes a learning model was set-up. The basis for the model is the understanding of fluid flow and diffusion in a textile fabric, which consists of a stagnant core and a convective shell. Wet textile processes are strongly influenced by mass transfer processes, where it is about the transfer of chemicals into and products out of a fabric. The mass transfer in the stagnant core is slow and in the convective shell the mass transfer is fast. A squeezing factor $\alpha$ has been introduced to explain the effect of the mechanical energy on mass transfer. The model provides some insight in the role of the dominating factors in mass transfer, which was qualitatively confirmed by lab experiments. Further it is elucidated that repeated refreshment of the volume in the capillaries of the yarn by the application of mechanical energy is of decisive importance in enzymatic textile treatments.

The knowledge and know-how that has been gathered on the enzyme cocktail, bleaching activators and on the necessity of mechanical energy in enzymatic wet textile processes has been transformed in a pre-treatment process for cotton on specific installed base. Subsequently experiments have been carried out on a full size pre-treatment plant and these confirmed the findings of the lab work in terms of desizing and hydrophilic properties of the fabrics. So it is concluded that industrial application of enzymatic desizing and scouring is possible. The developed bleach activation has not yet resulted in the particularly high whiteness standard of the hosting company. Under these conditions the optimal use of the bleach stabilizers is of dominant importance. Recently some industrial experiments have been carried out with a more thermostable manganese catalyst. Although the whiteness was importantly improved, when compared to the previous trials, this has not yet led to full realization of the high whiteness standard of the hosting company.

The performance on the whiteness of the fabric that has been treated on industrial scale with the new developed process still has to be further optimized. It is expected that this will be realized in future optimization trials. The reductions on water and energy consumption that have been realized and the decrease of the pollution load of the effluent are found to be substantial. 
It can be concluded that (bio)catalytic pretreatment of cotton on industrial scale is possible and leads to cost reductions in terms of less water and energy consumption and reduced wastewater treatment costs. 

In dit proefschrift wordt de ontwikkeling van een nieuw industrieel voorbehandelingproces voor katoen op basis van bio-katalyse beschreven. De conventionele voorbehandeling van katoen kent de processtappen ontsterken, afkoken en bleken, om vervolgens het katoen verder te kunnen bewerken in de ververij of in de drukkerij. Deze processen kunnen zowel continu als batch gewijs uitgevoerd worden. Recente ontwikkelingen in de genoemde processen op het gebied van enzymtechnologie en bleekkatalyse vormen de basis voor dit werk. Onderzoek van Agrawal naar enzymatische was- en pectineverwijdering van de katoenvezel en het onderzoek van Topalovic naar het katalytisch bleken van katoenen substraten hebben tot de conclusie geleid dat het mogelijk moet zijn om katoen voor te behandelen bij lage temperaturen met een gereduceerd waterverbruik. Een andere aanleiding voor het onderzoek is de aanhoudende en sterke druk die wordt uitgeoefend op de textielindustrie om meer en meer duurzame producten en processen te ontwikkelen en te implementeren.

Voor succesvolle industriële implementatie van het nieuwe voorbehandelingproces is het noodzakelijk om de academische kennis over katalyse te vertalen in een industrieel toepasbaar proces.

Deze vertaling van academische kennis naar industrieel toepasbare processen is in deze bedrijfstak vaak mislukt, enerzijds door gebrek aan ervaring van universitaire onderzoekers met de industriële processen en procesontwikkeling en anderzijds door gebrek aan kennis over academische research bij de industriële proces en productontwikkelaars. Deze problematiek treedt zich vooral op bij het Midden en Klein Bedrijf (MKB). Om deze kloof te vermijden is besloten om de samenwerking tussen de kennisinstellingen en industrie te organiseren. In de samenwerking staat centraal dat de betrokken participanten allen binnen hun werkveld van de nieuw ontwikkelde kennis dienen te profiteren.

Tijdens het onderzoek is eerst kennis verzameld over de eigenschappen en morfologie van katoenen substraten en de katoenvezel. Aansluitend zijn de conventionele voorbehandelingprocessen onderzocht. Voor een goed begrip van de conventionele processen was het noodzakelijk om naast de chemische en fysische aspecten inzicht te verwerven in de procescondities en de industriële installaties waarop deze processen worden uitgevoerd. Deze informatie vormt de basis voor het hier beschreven lab onderzoek naar de mogelijkheden van enzymatisch ontsterken en afkoken, gevolgd door katalytisch bleken. De kwaliteit van de behandelingen in de verschillende proces stappen is hierbij gemeten met behulp van industrieel geaccepteerde methoden.

Een enzym cocktail, bestaande uit amylase, cutinase en pectinase, is ontwikkeld ten bate van gecombineerd bio-katalytisch ontsterken en afkoken. De procescondities voor de toepassing van bio-katalytisch ontsterken en afkoken zijn onderzocht voor verschillende typen installaties en processen zoals die toegepast worden in de textielindustrie. Uit het onderzoek is gebleken dat gecombineerd bio-katalytisch ontsterken en afkoken attractief lijkt voor de industrie, waarbij een belangrijke reductie van de reactie- en de procestemperatuur tot verschillende voordelen leidt. De kwaliteitsmeting van het doek dat op deze wijze is behandeld laat zien dat, indien deze wordt 
vergeleken met een conventionele behandeling, de kwaliteit van het behandelde doek minstens zo goed of beter is dan de huidige industriële standaard, terwijl de gebruikte enzymconcentraties nog niet geoptimaliseerd zijn.

In het onderzoek naar het bleekproces met de toepassing van de mangaan katalysator is het doek voor het bleken eerst behandeld conform het nieuwe voorbehandelingproces met de enzymcocktail. Hiertoe is besloten teneinde het verwachte voordeel van de gecombineerde voorbehandeling ten volle te benutten. Van belang is hierbij dat de was en pectineverwijdering in het conventionele proces vooral plaats vindt tijdens het bleken, waar in het nieuw proces deze producten al verwijderd worden tijdens het enzymatisch ontsterken en afkoken. Tijdens het onderzoek naar de mogelijkheden van katalytisch bleken is getracht de industriële omstandigheden waar mogelijk na te bootsen. Het gebruik van de katalysator bij $100^{\circ} \mathrm{C}$, zoals gebruikt in een stoomkast, leidt echter tot decompositie van de katalysator en dit resulteert in onvoldoende ontleding van waterstofperoxide waardoor een onvoldoende bleekeffect wordt gerealiseerd. Deze waarneming heeft geleid tot de conclusie dat katalytisch bleken in de huidige stoomkasten niet mogelijk is, echter ook niet bij lage temperatuur. Dit laatste wordt veroorzaakt door technische beperkingen, die niet gemakkelijk opgelost kunnen worden zonder omvangrijke investeringen. Derhalve is besloten om katalytische bleekexperimenten in bekerglasproeven uit te voeren zonder toepassing van de reactietijden en condities van een stomer. Het is tijdens de experimenten duidelijk geworden dat katalytisch bleken bij lage temperatuur uitsluitend toepasbaar is bij discontinue bleekprocessen in waterig milieu. Een opvallend resultaat van de bleekexperimenten was dat bio-katalytisch ontsterken en afkoken het mogelijk maakt om tijdens het bleekproces de concentratie natronloog aanmerkelijk te reduceren. In het conventionele proces is het gebruik van hoge concentraties natronloog noodzakelijk om de waslaag van de katoenvezel te verzepen en de pectine in de primaire wand af te breken. Zoals reeds gezegd wordt de waslaag en de pectine van de katoenvezel in het nieuw ontwikkelde proces tijdens de eerste, de bio-katalytische, stap al gerealiseerd en niet meer tijdens het bleken.

Natte textielprocessen zijn afhankelijk van massatransport van chemicaliën uit de bulk van de behandelvloeistof naar het textiele substraat en van reactieproducten uit het doek naar de bulk. Teneinde het belang van massatransport in de bio-katalytische voorbehandeling vast te stellen is een leermodel ontwikkeld. Het doel van het model is inzicht te verwerven in vloeistofstromen en diffusie in een textiel substraat, dat bestaat uit een convectieve en een stagnante zone. Het massatransport in het stagnante gebied is langzaam en in het convectieve gebied is het transport snel. Een afpersfactor $\alpha$ is geïntroduceerd teneinde het effect van mechanische energie op het textiele substraat te verklaren. Het model levert inzicht in de bepalende factoren voor massatransport, die kwalitatief bevestigd kon worden door lab experimenten. Daarnaast is modelmatig vastgesteld dat mechanische energie van doorslaggevend belang is in enzymatische processen voor de verversing van de inhoud van capillaire gebieden in het textiel.

De kennis die is verworven over het enzym cocktail, de bleekactivatoren en de noodzaak van mechanische energie hebben geresulteerd in een voorstel voor bio-katalytische voorbehandeling van katoen voor een specifieke installatie. Tenslotte zijn op industriële schaal experimenten uitgevoerd en deze hebben de resultaten, in termen van ontsterkingsgraad en hydrofiliteit verkregen op lab schaal, bevestigd. Op basis van deze experimenten op commerciële schaal is geconcludeerd dat enzymatisch ontsterken en afkoken op industriële 
schaal mogelijk is. De bleekstap van het nieuwe proces heeft nog niet geleid tot het realiseren van de vereiste hoge standaard witheid van de referentie onderneming. Het is gebleken dat bij de gebruikte procescondities een andere bleekstabilisator noodzakelijk is.

De witheid van het volgens het nieuwe proces behandelde doek op industriële schaal dient dus nog verder verbeterd te worden. De verwachting lijkt gewettigd dat de vereiste witheid in de eerstvolgende experimenten kan worden gerealiseerd. Opgemerkt dient te worden dat de gerealiseerde witheid al voldoet aan de meest gangbare eis voor witheid bij andere veredelingsbedrijven. De gerealiseerde reductie van het water en energieverbruik, alsmede de afname van de vuillast in het effluent is substantieel.

De eindconclusie is dat bio-katalytische voorbehandeling van katoen op industriële schaal mogelijk is en dat dit proces leidt tot besparingen in termen van water en energieverbruik en reductie van de kosten van het lozen van afvalwater. 



\section{Introduction}

The wide use of cotton and the high consumption of water and energy for cotton wet-textile processing underlines the urge for improvement of the treatment to reduce the use of the scarce resources water and energy. Textile industry is conservative in adapting new processes. Never thereby the importance of process improvement increases with the increasing scarcity of the resources water and energy and forces the conservative textile industry to adapt new processes. To realize process improvement it is necessary that knowlegde institutes and industry work closely together. 


\subsection{General}

Cotton is since centuries one of the most important and widely used textile fibres. Cotton is produced in big volumes. The annual global production is about 25 million tonnes. For the production of the cotton, from fibre to garment, high quantities of water and energy are used.

In the present time we highly value the sustainability concept as a tool to improve quality of life, or at least not to use natural resources in quantities as we are doing until now. More and more people realize that natural resources are not inexhaustible. This change in thinking about natural resources has been a starting point for many research activities with the focus on improved sustainability.

In cotton cultivation the research focus is on reduction of pesticides and fertilizers [Kooistra et al, 2006]. Awareness of exhaustible fresh-water resources stimulates research for efficient water usage for growing cotton [WWF Home page]. Before a cotton fabric is used as a garment it has to be coloured and prepared for use by giving it the desired properties. These processes are the so-called wet textiles processes, which consume high volumes of water and energy. Wet textile processes are an important research area for improvement of sustainability and many researchers are working on this topic [Agrawal, 2005, Cavaco-Paulo \& Guebitz (Ed.), 2003, Csiszar et al., 2006, Topalovics, 2007 and Tzanko et al. 2002]. Important research areas are cotton pre-treatment with the focus on water and energy reduction, dyeing and printing with improved dyes, which meet environmental demands and finishing of cotton fabrics with less harmful chemicals and at low temperature. Drivers for process changes in industry are quality improvement, cost reduction and improved sustainability. Drastic cost reduction by improved sustainability due to bio-catalytic treatment is predicted at the conference EuropaBio [EuropaBio, Press release, 2003].

\subsection{Focus of this research}

This research focuses on cotton pre-treatment by enzymatic processes. Enzymatic pretreatment of cotton is already known for many decades in the textile industry. In the beginning of the $20^{\text {th }}$ century the enzyme amylase is introduced in textile industry as a desizing agent. Nowadays it is the most important desizing agent for starch sizes. The call for sustainable processing brought emphasis to use enzymes for other pretreatment steps and the door is opened for new enzymes and applications, but also for research to improve the application of existing enzymes [Agrawal, 2005, Cavaco-Paulo \& Guebitz (Ed.), 2003, Csiszar et al., 2006 and Tzanko et al. 2002]. Research for enzymes to improve sustainability is fed by the knowledge that enzymes generally catalyze reactions in benign environment [EuropaBio, Press release, 2003]. Bleaching of cotton is also an important subject for research [Hage \& Lienke, 2006, Topalovic, 2007]. In this work the options for low temperature bleaching are also investigated and evaluated.

Researches have put a lot of effort in developing new processes for the textile industry to create sustainable processes, new products or to reduce costs. Rather successful was the introduction of new 'nano' related products. Products with anti-bacterial, cleaning and protecting properties have recently been marketed. Textile companies focus rather on product development as strategy than on process development. Despite all this research hardly new processes are 
implemented. In the past new processes were mainly developed by chemical and installed base suppliers. Due to economic reasons new process developments have been very scarce. Arguments that are used to explain this are re-allocation of textile industry, cost of development and competitive pressure on sales. Struggle for survival led to a product development rather than process development.

\subsection{Hesitation to adapt a new process}

Textile industry is known as a conservative industry where it is very difficult to implement new processes. The major reason for hesitation in adapting a new process is the high cost of implementation in combination with the risk of failure. Until now many textile processes are not fully analyzed or the interaction between chemistry, fabric and installed base is not fully explored and known. This lack in knowledge also hinders development, as researchers and industry are not always able to oversee the consequences of changes or the risks of hidden defects. These arguments have to be taken into account to implement new processes to improve sustainability and reduce costs.

The goal of this research is "the development of an innovative (bio)-catalytic pre-treatment process for cotton on industrial scale". The objectives of the new process are improvement of sustainability. This improvement is measured in terms of reduction of water, energy and effluent load. Industrial demands are no reductions of capacity, reduction of costs and the quality level has to be at least as good as conventional production. The new developed process has to be implemented in the industry, taking into account the fabric to be treated and the available installed base. Knowledge on fabrics and installed base is a prerequisite for a successful application of a new process. This gives the research a multi-disciplinary character in terms of chemistry, mass transfer and textiles production processes. Therefore it is necessary that academic institutes collaborate closely with the textile industry.

\subsection{Outline of this thesis}

The outline of this thesis is as follows:

- In Chapter 2 general information on cotton and its history is presented. The application areas and the desired properties of the textile fabrics are presented. The morphology of the cotton fibre is described. The pre-treatment steps before dyeing and printing are related and explained on the basis of this knowledge. In general terms the different pre-treatment processes are discussed and the installed base for the distinctive treatments are presented.

- Chapter 3 reports on the development of the enzymatic pre-treatment step. Here the enzyme cocktail, containing amylase, cutinase and pectinase, is introduced. Evaluation techniques for desizing and scouring are discussed. The work on enzymatic seed coat fragment degradation is evaluated. Finally the operating window for the enzymatic pre-treatment step is presented.

- In Chapter 4 the bleaching step, aimed at sustainable treatment is presented. The use of a manganese catalyst is evaluated and compared with the performance of conventional bleaching. The operating window for bleaching is presented. 
- In Chapter 5 we have derived models to get more insight in the role of the mechanical energy. Mechanical energy is studied in relation to convective and diffusive mass transfer in a fabric. A model has been developed that describes the effect of mechanical energy in terms of squeezing action. Squeezing is seen as a means to accelerate the mass transfer processes. Experiments are presented that validate this model qualitatively. Besides a model is presented to show the importance of mechanical energy in the maximum adsorption of enzymes at the substrate surfaces.

- Chapter 6 gives a description of the experiments at industrial scale. These experiments are carried out on full width. The basis for the industrial experiments is found in the previous chapters and translated to the specific situation. Major differences are determined between the requirements after the treatment (depending on fabric and consecutive processing), installed base and previous treatments. Per industrial experiment the set-up, recipes and operating window is discussed and related to the theory of the new process.

- Finally in Chapter 7 an economic evaluation has been given. Calculations have been done for the chemical costs, the reduction in water and energy consumption and the effect on wastewater costs. 


\section{References}

Agrawal, P.B., "The performance of cutinase and pectinase in cotton scouring", ISBN 90-3652243-9, Thesis University of Twente, the Netherlands, 2005

Cavaco-Paulo, A. and G.M. Gübitz, "Textile processing with enzymes", ISBN 1-85573-610-1, Woodhead Publishing, 2003

Csiszár, E., A. Losonczi, B. Koczka, G. Szakács and A. Pomlényi, "Degradation of lignincontaining materials by xylanase in biopreparation of cotton", Biotechnol Lett, volume 28, 749753,2006

EuropaBio, "White Biotechnology(bioprocesses): a gateway to a more sustainable future", Press release, April 10, 2003

Hage, R. and A. Lienke, "Applications of transition-metal catalysts to textile and wood-pulp bleaching", Angewandte Chemie Int. Ed., Volume 45, p206-222, 2006

Kooistra K.J, Pyburn, R. and A.J. Termorshuizen, "The sustainability of cotton. Consequences for man and environment", Science Shop Wageningen University \& Research Centre. Report 223. ISBN 90-6754-90-8585-000-2, 2006

Topalovic, T., "Catalytic bleaching of cotton: Molecular and macroscopic aspects", ISBN 90-3652454-7, Thesis University of Twente, the Netherlands, 2007

Tzanko, T., M. Calafell, G.M. Gübitz and A. Cavaco-Paulo, "Hydrogen peroxide generation with immobilized glucose oxidase for textile bleaching", Journal of Biotechnology, 93(1), 87 - 94, 2002

WWF report 2406, "Cleaner, greener cotton”, published October 2007 http://assets.wwf.ch/downloads/bericht cleaner greener cotton in english .pdf last time visited November $24^{\text {th }}, 2010$ 



\section{Cotton from plant to fabric}

In this chapter information about the history and application of cotton is presented. It describes the journey from cotton fields to a cotton-fabric, which is until now one of the most important textile materials. The pre-treatment processes of cotton are related to the morphology of this fibre. The considerations to select the pre-treatment process and the process conditions have been discussed. 


\subsection{Introduction}

Mankind has always protected themselves from harsh environmental conditions like cold, sunlight, rain etc. In more general terms the primary function of clothing is protection, covering and distinction. The protective properties of textiles can be aimed at various hazards like weather conditions, but also hazards that are related electric conductivity, flame-ability, chemicals etc. Sometimes clothes render protection to the wearer by high visibility for roadworkers or just not to be seen for instance for armed forces. Coverage is the property of textiles to cover for instance a person against light, being seen, wounds, to become wet etc. The last function that is mentioned for clothing is the opportunity to distinct one person or a group from others. The choice of garments express in this case often the wearer's emotions. Other applications for textiles are household, upholstery and technical products.

The first materials used as garments where furs, leather and leaves. Later wool and other products became available. In fact in ancient times, when people where able to produce a twodimensional structure from fibres a new production technology started: the textile industry. The fibres used came from animals or plants. Until now the major fibre from plants is cotton. Comparison between cotton, wool and synthetic fibres shows that the relative position of cotton is $38 \%$ of the total volume of fibres that are used for textiles, where wool is about $2 \%$ and synthetic fibres form about $60 \%$ of the annual production in 2005 [Koslovski (Ed.), 2006]. From 1980 until 2000 the growth of world population was 38\%, while the growth of cotton in that period stuck at $36 \%$. It is assumed that the demand for cotton is related to the global population. Faster growth of global population than global production of cotton implies extra growth of synthetic fibres to fulfill the demand for textiles. The annually cotton production increases and nevertheless the relative position of cotton decreases slightly due to growth of production of synthetic fibres [Koslovski (Ed.), 2006]. Despite the relative growth of the synthetic fibre cotton has still an important position due to its properties. The major comfort properties are thermal insulation, moisture handling and next-to-skin comfort. These comfort aspects are due to relative fine and flexible fibres. Cotton can absorb up to $20 \%$ water, without feeling wet. The water uptake capacity is up to $60 \%$, without the fabric starts to drip. The next-to-skin comfort is high because the fibre is fine and soft. Cotton develops -under average use- no electrostatic charging as it always contains water, resulting in discharging of the fabric. The combination of these properties and the relative low price give cotton this important position in the worldwide use of fibres. It is not expected that this position will drastically decrease in the near future and this justifies this research.

In the last decades a lot of energy is put into the development and use of organic cotton. Organic cotton is cotton that is produced without the use of fertilizers and pesticides. The aim is to realize sustainable cotton crop production [Kooistra et al., 2006]. Although the production of organic cotton is increasing the production volume until now is very small. It is less than $1 \%$ of annual global production of cotton. In $2007 / 2008$ the quantity organic cotton grown up to $0,76 \%$ of the global volume of harvested cotton [Organic cotton exchange, 2010]. 


\subsection{History of cotton}

The first known use of cotton is of the period of 5000 BC. Pieces of cotton where found in caves in Mexico. The species found was Gossypium hirsutum. This cotton variety is still the most widely grown cotton species in the world and is about $90 \%$ of global harvested cotton. This cotton is very similar to American cotton types. In Mohenjo Daro, an ancient city in the area West Pakistan, a cotton fabric is found that is from the period $3000 \mathrm{BC}$. This cotton is harvested, spun and woven in the Indus River Valley. The Indus cotton industry was, in that time, well developed and some ancient technologies that have been used in spinning and weaving are still the basis for equipment that is presently used in the textile industry. Also cotton fabrics, that are from the same era as the cotton in West Pakistan, is found in the Nile Valley in Egypt [National cotton council, website]. Greek and Arab merchants first ignored cotton. It lasted until $800 \mathrm{BC}$ before Arab merchants introduced cotton in Europe. The interest for cotton increased in $400 \mathrm{BC}$ when the Greek historian Herodotus wrote that in India there were trees producing a sort of wool that is better than wool produced by sheep. This might explain the German word for cotton "Baumwolle". In the first era after Christ's birth the Arab traders brought fine muslin and calico to Italy and Spain. The Moors in Spain introduced cotton cultivation the $9^{\text {th }}$ century AD. In Italy, Venice and Milan, the first cotton/linen fabric is produced with a linen warp and cotton weft. Around 1500 it is for the first time reported that cotton is imported in England and from here cotton products spread fast over the world. In the beginning cotton was a very luxurious product, but with increasing growth and production cotton became more and more available for common people. The industrial revolution in Britain boosted the manufacturing of cotton fabrics. In this time the roller-spinning machine of Lewis Paul and John Wyatt of Birmingham has been developed. This invention has been followed by other inventions and developments, which made the area of Manchester (England) the global heart of the cotton trade and developments.

Cotton products and trade have had for a long time a major influence in history. The textile revolution in England boosted the production capacity so enormously that the leading cotton supplying country India could not follow the demand. Therefore the English producers had to search for an alternative supplier and imported their cotton for an increasing part in the United States. Due to the American civil war the American production decreased tremendously and the English traders had once again to search for alternative sources. Egyptian producers could meet the large demand for cotton. However after the ending of the American Civil War the English traders decided to use the cheaper American cotton again, leading to the bankruptcy of Egypt in 1876. This bankruptcy of Egypt was one of the main factors for Egypt's annexation by the British Empire in 1882. The production of cotton and its fabrics have been shifted over many countries and even over continents. Major arguments for the shifting during the middle ages were economic reasons, sometimes caused by political instability. Nowadays the shift of textile production of the countries or continents has also been dictated by either economic or political reasons and it is believed that the shift of textile production will continue.

During many centuries the production technology of textiles has been improved gradually. The industrial revolution in England boosted in the development of textile technology but also the development of synthetic fibres in the mid of the $20^{\text {th }}$ century contributed to a large extend to further generation of textile technology. 


\subsection{Application of cotton}

It is already mentioned in this work that there are many applications of cotton. Major application areas are:

- clothing;

- household;

- interior;

- technical textiles.

\section{Clothing}

Cotton is widely used and it is by far the most important natural fibre for clothing. Cotton owes this position to its high relative strength, but also the soft handle and perfect moisture absorption capacity make these fabrics to preferred products. Cotton is very much suited for dyeing or printing and a number of dyestuff-groups with different chemical structures and dyeing properties are available. This makes the fabric very fashionable. Various finishing options make it possible to produce a cotton fabric that has been modified to fulfill the end-users requirements. The application of cotton fabrics varies from coats to T-shirts and from casual clothing to evening dresses. Cotton garments are relatively easily cleanable in domestic laundry.

\section{Household}

Cotton is used in household in almost all applications that require water uptake. The water uptake capacity of cotton is about $60 \%$ of its own weight, before the fabric starts to drip. Here it is important to realize that cotton is stronger when it is wet, where other textile fibres decrease in strength after wetting. Another household application of cotton is bed linen. For bed linen the same arguments can be used as for rubbing cloth. For both applications the water up-take capacity even up to $20 \%$ of the fabric weight gives not a wet feeling to the product. Good tensile strength properties for bed linen are important, when sweating wets the fabric. Dyeing and or printing properties of household linen make these products fashionable.

\section{Interior}

The handle of the fabric, the drape- and tensile strength properties make cotton fabrics suited for interior applications. Dyeing and printing increase the suitability for cotton for interior products as it gives the consumer the option for personalizing the interior and for distinction. Requirements for different applications are met after finishing the fabric. Properties that are added to the fabric are easy care, flame retardant properties etc. Cotton is used in interior products as seats, curtains, in-betweens, floor covering etc.

\section{Technical textiles}

Cotton is used in technical textiles for its properties as tensile strength, wet and dry, resistance to chemicals, water uptake but most of all the various possibilities to add functionalities to the fabrics by finishing processes. An important technical application is medical textiles. The reusability and easy cleaning properties are important for this application. 
Cotton is the most important natural fibre that is available in high volumes at a relatively low price. The low price in combination with the properties of cotton fabrics makes it hard to replace cotton by other fibres, either natural or synthetic. Therefore it is not likely that the consumption of cotton will decrease in the future. This is confirmed by historical data about the growth of the global population and consumption of cotton that show a similar development. [Unctad market information, 2010].

\subsection{Cotton properties}

Cotton is a hair, that is attached to the seed of plants Gossypium botanical genus of the mallow family. After planting it takes about 175 - 225 days before cotton can be harvested. During growth cotton flowers after about $8-10$ weeks. When the blossom falls a small triangular pod is formed, that grows to the size of a walnut. This is the so-called cotton boll that contains $20-30$ seeds. Each seed contains about 2000 - 7000 hairs, depending on the cultural strain. The epidermal cells start to elongate. After about 18 days the cell wall starts to thicken and elongation of the hair stops. Maturity of the hairs is reached $50-60$ days after flowering and the boll bursts open, showing the fine cotton hair. After harvesting the bolls are allowed to ripen and dry for about 30 days. The seeds and hairs are separated in the ginning process. The height of the cotton plant varies between 0.25 - $2 \mathrm{~m}$, depending on cultural strain, cultivation and climate [Wakelyn \& French (Ed.), 2007, Rouette (Ed.), 2001, Swicofill website].

Cotton cultivation occupies more than 30 million hectares of global arable land. For cultivation of cotton 8500 litres of water (rainfall and irrigation) per kilogram cotton lint is used. These volumes vary strongly per area. In China there are cotton areas where less than 5.000 litres water per $\mathrm{kg}$ cotton lint is used, but there are also areas in India, where more than 20.000 litres of water per $\mathrm{kg}$ cotton lint is used [WWF, cleaner,greener,cotton, 2007]. More than 20 million farmers are world wide involved in cultivating cotton. This cultivation consumes about $11 \%$ of the world pesticides, while only $2.4 \%$ of the arable land is used. Per ton of harvested cotton about $400 \mathrm{~kg}$ fertilizers and $40 \mathrm{~kg}$ pesticides are used [Rouette (Ed.) 2001]. Annual global production of cotton is approximately 25 million-ton. Major cotton producing countries are China, with a share of $24 \%$ of the global production, followed by the United States of America, with a share of $19 \%$, India with a share of $16 \%$ and Pakistan, that produces $10 \%$ of the global volume. The rest of the production is spread over more than 100 countries. 


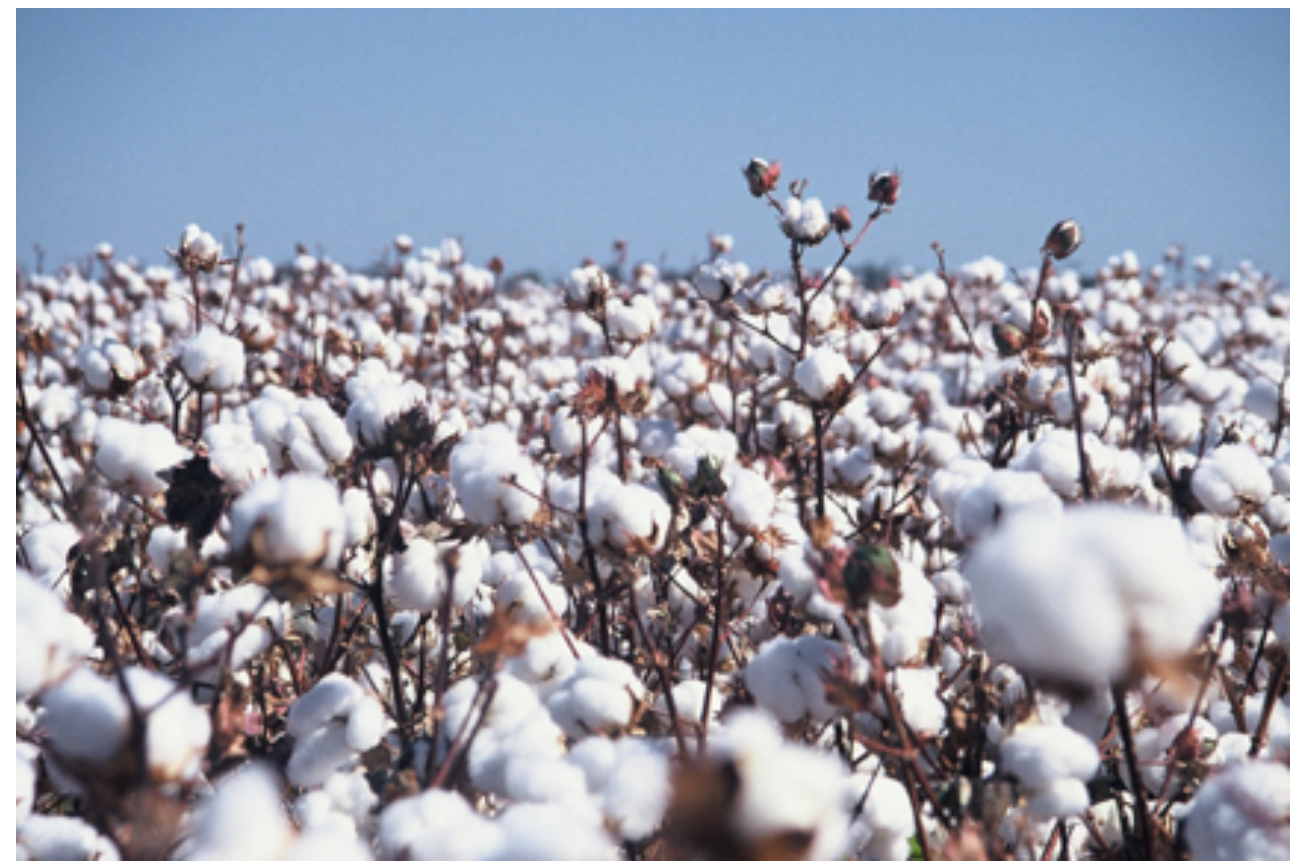

Figure 2.1: Cotton field

The length of the fibre varies from $26 \mathrm{~mm}$ (short staple) to $>39 \mathrm{~mm}$ (extra-long staple) [Rouette (Ed.), 2001]. Cotton is a fine fibre, with a weight per unit length between 1 and 4 dtex. Tex is the mass in grams per kilometre of fibre or yarn. Dtex is the mass in grams per 10 kilometre of fibre.

The cotton fibre consists cellulose chains that form the elementary fibrils. The elementary fibrils form micro fibrils. These fibrils are grouped together in the cotton fibre. In the following list the construction of the fibre is shown and quantified, including the diameter of elementary and micro fibrils:

- 1 cotton fibre:

15.000 micro fibrils

- 1 micro fibril: 400 elementary fibrils

- 1 elementary fibril: 100 cellulose chains arranged in $6-8$ packages

- diameter of micro fibril: $200-300 \mathrm{~nm}$

- diameter of elementary fibrils: $3,5 \mathrm{~nm}$

Cotton fibres (figure 2.3) consists from the outside to the inside of:

- cuticle, the outermost layer;

- primary wall;

- winding layer;

- multi layered secondary wall;

- lumen.

After harvesting the cotton fibre dries and this causes the collapse of cotton fibres, as it is shown in figure 2.2. The collapse is due to a different shrinkage of the primary and secondary wall. The primary wall shows less shrinkage than the secondary wall, because its network structure. This 
effect results in the well-known kidney form of dried mature cotton. Reversely after swelling, caused by moisture absorption, the cross section of the fibre is circular.

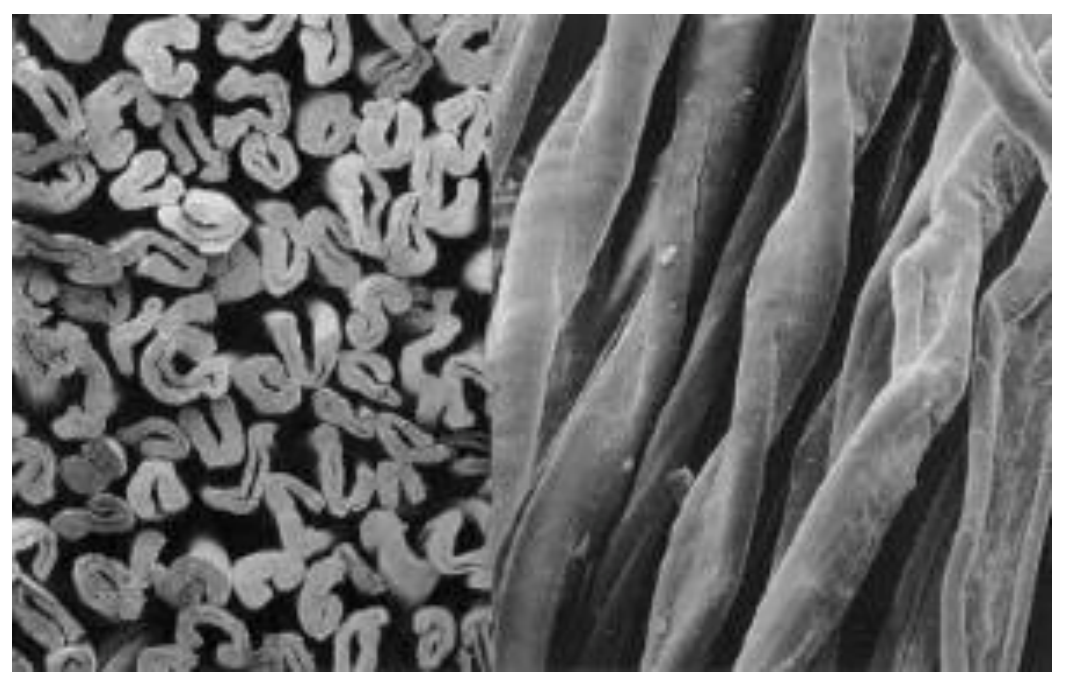

Figure 2.2: Kidney shape of dried cotton fibre

The cuticle

The cuticle is the outermost layer of cotton fibre, the so-called cotton wax. It overlays the primary cell wall and its main function is to protect the fibre from dehydration. Other functions are protection against external physical and chemical attacks. In the spinning process the waxy layer gives a soft hand but also improves spinning quality due to less friction. Chemically the cuticle consists of free unsaponifiable high molecular alcohols, higher fatty acids of high molecular weight and others, which give the cuticle a strong hydrophobic character.

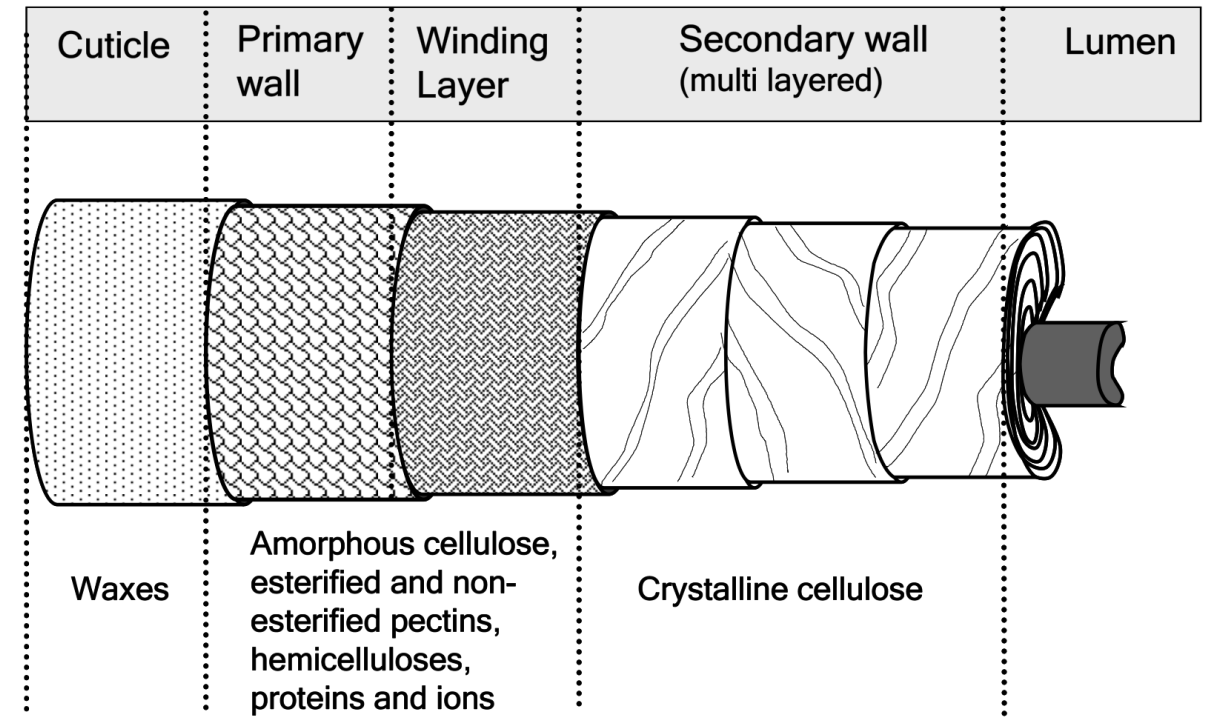

Figure 2.3: Schematic representation of mature cotton fibre [Agrawal, 2005] 
Hot alkaline liquors via saponification can remove around half of the cotton wax. The rest is insoluble and only emulsifiable. The melting temperature of cotton wax is $70-75^{\circ} \mathrm{C}$ [Rouette (Ed.), 2001].

\section{The primary wall}

The primary wall is a thin film around the fibre and consists of amorphous cellulose and noncellulosic materials. Constituents of the primary wall are cellulose, hemicelluloses, glycoprotein, pectin, coloring matters and traces of metal.

The cellulose in the primary wall has a lower degree of polymerization than the cellulose in the secondary wall. The cellulose in the micro fibrils in the primary wall has a crystalline structure of $\beta$ (1-4)-linked glucose monomers and is surrounded by a matrix of other non-celluloses. Therefore the primary wall determines the tensile strength of cotton [Rouette (Ed.), 2001].

Hemicellulose is a heterogeneous ill-defined group of a branched matrix forming polysaccharides. The molecular weight is lower than cellulose and the degree of polymerization is 150 or less. Hemicellulose plays an important role in cross-linking cellulose micro fibrils in the primary wall. Besides the interconnection of hemicellulose also glycoproteins play an important interconnecting role in the primary wall. Glycoproteins consist of a protein backbone with protruding rods, which are glycosylated. Disulfide bonds covalently link the glycoprotein molecules. They often contain an oligosaccharide chain, which is interconnected with other polysaccharides in the primary wall. This is schematically shown in figure 2.4 .

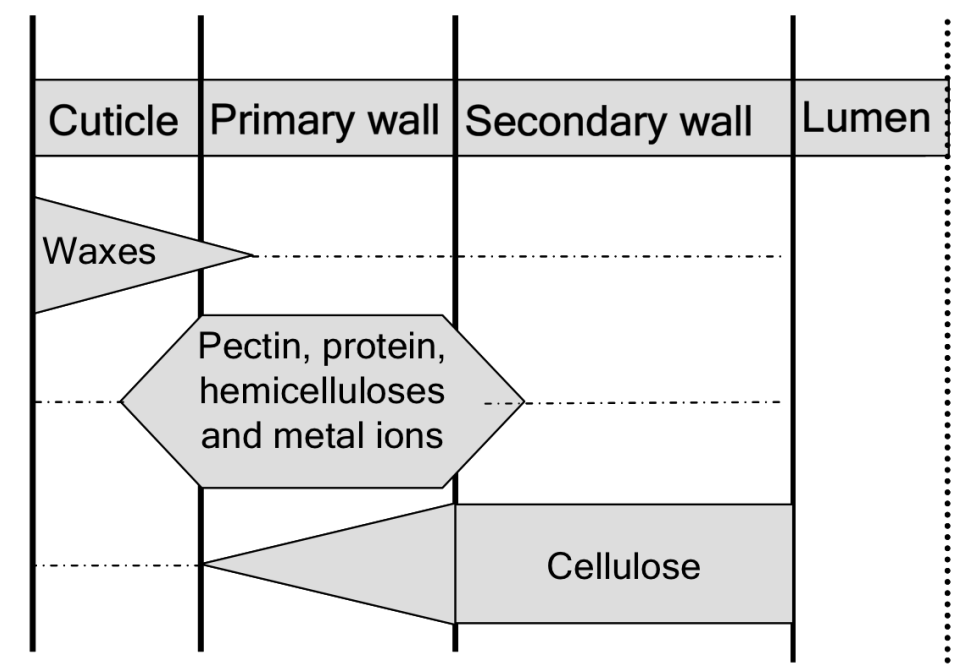

Figure 2.4: Schematic representation of the main constituents different layers of cotton [Agrawal]

Pectin is a non-cellulosic material (acidic polysaccharides). The role of pectin is to give firmness and structure to the fibre, in the primary wall as well as in the winding layer, which is the outermost layer of the secondary wall. In the primary wall pectin acts as connecting material in the cellulose network. Cotton contains two types of pectin. The outer layer of the primary wall contains esterified pectins. Esterified pectins allow the primary wall to extend during growth, as they are less stable to humidity and heat. Non-esterified pectin contains more charged groups 
and is straighter than esterified pectin and forms a $\mathrm{Ca}^{2+}$ bridge. The $\mathrm{Ca}^{2+}$-bridge cross-links with other non-esterified pectins [Wakelyn \& French (Ed.), 2007]. These cross-links function as a network to hold the cell wall components together.

The natural colouring matter is present only in traces and the composition has not been established with certainty. Cotton is a natural grown fibre and therefore growing conditions influences its appearance. The faint creamy colour of raw cotton is not known for certain, but it here it is possible that the fibres contain some flavonoid pigments that are present in the cotton flowers and cotton seed. The brownish colour of cotton is studied more thoroughly. This pigment consists of flavones such as morin and gossypetin. Cotton fibres contain also a considerable amount of polyphenols such as gossypol, flavone and tanning substances. The content of these substances depend on the maturity of the fibre.

\section{The winding layer}

The winding layer is the connecting layer of the primary and secondary wall. The layer consists of cellulose micro fibrils, which are oriented along the fibre axis. The interconnections are mostly stabilized by $\mathrm{Ca}^{2+}$-ions, making the interconnections in the winding layer stronger than the outer layers. Due to the strong interconnections only limited swelling of the secondary wall is possible, thus making the secondary wall less accessible to external damage.

\section{The secondary wall}

The secondary wall of the cotton fibre consists of three different layers. The layers as such consist of closely packed fibrils (crystalline regions) with a spiral winding of $25-35^{\circ}$. The direction of the winding in the different layers is axial opposite to the next layer. These are the $S$ and $Z$ twists. The main chemical constituent is cellulose. The spiral gives cotton its stability in swollen state. The difference in shrinkage of the primary wall and other layers cause the shape of the fibre after drying, the kidney bean shape. The process of drying resulting in this kidney shape is reversible.

It is stronger in the wet state than in the dry state due to hydrogen bonds. These bonds have been formed due to the presence of $\mathrm{H}_{2} \mathrm{O}$ to in the amorphous regions and connect the cellulose macromolecules. The formed hydrogen bonds in the amorphous region give cellulosic crystalline fibrils more flexibility, and thus more elongation and thus higher tensile strength [Miyake et al. 2001].

The lumen

The lumen is the cavity in the single-celled cotton fibre, which encloses dead protoplasm. During the drying of the cotton fibre the lumen collapses. The lumen itself is enclosed by the secondary wall. 


\subsection{Cotton production processes}

Many different steps are involved in the transformation of harvested cotton into fabrics that are ready for garment production. In general terms the production steps can be divided in two different processes:

- structuring processes;

- wet textile processes.

\subsubsection{Structuring processes}

Structuring processes are processes that are necessary to produce a fabric from an individual cotton fibre. The major structuring or structuring related processes are listed below:

- ginning;

- spinning;

- sizing;

- weaving;

- knitting.

\section{Ginning}

The first step is to separate the cotton fibres from the cottonseed. This process is called ginning and is done nearby growing area of the cotton plant. In the ginning process the following products and their quantities are separated after working up $100 \mathrm{~kg}$ cotton bolls [Rouette (Ed.), 2001]:

- $35 \mathrm{~kg}$ fibres;

- $62 \mathrm{~kg}$ seeds;

- $3 \mathrm{~kg}$ trash.

Trash is all materials that are not cotton or seed, e.g. plant rests as leaves and small branches. After ginning the cotton is packed in bales and shipped to the spinner.

\section{Spinning}

The first process in the spinning mill is mixing cotton from different, production regions. Often 6 different originated cottons are mixed. This mixture makes the spinner less dependant of the supply of cotton from one region. Generally the yarn buyers do not notice the difference when one of the six mixed cottons is changed and so the spinner supplies a 'constant' yarn quality. During the mixing process the fibres are opened and a mechanical cleaning is done. All next processes in the spinning mill are aimed at positioning the fibres in the length direction and to realize equal fineness (thickness) over the length of the yarn. The doubling and stretching process is repeated to optimize the regularity in the yarn. The yarn becomes finally its strength by twisting the fibres around each other. Well-known spinning processes are ring-spinning and open-end spinning. In ring-spun the fibres are partially anchored in the core of the yarn and are all twisted in the same direction. This partial anchoring of the yarn causes the hairiness of ringspun yarn. In the open end spinning process the fibres are fed to a rotor and twisted. The core of rotor spun yarn has a constant twist, which is comparable to ring-spun yarn. However this openend spinning process wraps the fibres also on the outside of the core and here the fibres are 
twisted in both directions, $S$ and $Z$. The consequence is that this yarn cannot be opened completely by untwisting. This wrapping effect also explains the reduced hairiness of open-end spun yarn.

\section{Sizing}

Knitting or weaving is the next step in the production process of a two-dimensional plain cotton product. In the weaving department the warp has to be impregnated with a size, which is a warp strengthening composition of chemicals solved or dispersed in water. Most common sizes are starch derivates, but also other natural products and synthetic sizes are used. The warp is impregnated with the size in the sizing-department. On a weaving loom the sized warp is woven with the weft into the fabric. The aim of sizing is to improve weaving efficiency. The size 'glues' fibres, which 'strengthens' warp and therefore less warp-threads break during weaving. It is believed that the most important property of sizing is the decrease of friction on the weaving loom and therefore less yarns breakage and to realize thus less stops of the loom. In a knitting department there is less tension on the yarn and therefore the yarn has not to be sized.

\section{Weaving}

After sizing the warp yarn it can be used to produce a woven fabric. Weaving is the conversion of yarn into fabric by interlacing two independent yarn systems, warp and weft on a weaving machine (loom). Many constructions are known. Some well-known constructions are plain, twill and satin weave. The looms that can be used for weaving are very different. The major weaving techniques are shuttle, projectile, rapier, water and air weaving machines. These weaving machines differ in the way they transport the weft yarn through the shed. The selection of looms is based on the weight of the fabric, construction and the fibres that are used. After weaving the fabric is shipped to the finishing department.

\section{Knitting}

Knitted fabrics are made from interlocking loops formed from a yarn. The types of knitted fabrics that are distinguished are warp and weft knitted fabrics. The most well known weft knitted fabric is single jersey. This fabric is often used in garment production (T-shirts). Other -more dimension stable- knitted fabrics are warp knitted velour, which is applied for upholstery or lace curtain. These products are produced on a flat bed warp-knitting machine.

After knitting or weaving the fabric has to be coloured and finished to fulfill the consumers requirements.

\subsubsection{Wet textile processes}

After the structuring process fabrics have to be coloured and finished according the customers demands. First the fabric is pre-treated for dyeing and finishing. In this process the fabric is cleaned and unwanted products or properties are removed. Consecutively the fabric can be coloured. Colouration is either done by dyeing or by printing. At last is the fabric finished to obtain the required properties for the end-user such as resistance to shrinkage, water repellency, flame retardancy etc. In the following table the three main wet textile processes and their sub-processes are described. 


\begin{tabular}{|l|l|}
\hline \multicolumn{2}{|c|}{ WET TEXTILE PROCESSES } \\
\hline PRE-TREATMENT & singeing \\
\cline { 2 - 2 } & desizing \\
\cline { 2 - 2 } & scouring \\
\cline { 2 - 2 } & bleaching \\
\cline { 2 - 2 } & drying \\
\hline COLOURING & dyeing \\
\cline { 2 - 2 } & printing \\
\hline \multirow{2}{*}{ FINISHING - mechanical } & raising \\
\cline { 2 - 2 } & calendring \\
\cline { 2 - 2 } & sanforizing \\
\hline FINISHING - chemical & impregnating \\
\cline { 2 - 2 } & coating \\
\hline
\end{tabular}

Table 2.1: Wet textile processing

As already stated the pre-treatment process is aimed at preparing cotton fabric for further treatment such as dyeing and/or printing and finishing. To realize a high quality level of pretreated cotton there are a number of consecutive steps to be carried out. These processes are singeing, desizing, scouring and bleaching. The requirements for cotton before dyeing or printing are a uniform clean, hydrophilic and white fabric. The preparation of the cotton fibre for further processing is called pre-treatment of cotton. In table 2.2 the constituents and their relative content in the cotton fibre and outer layer of the cotton fibre are shown.

\begin{tabular}{|l|c|c|}
\hline \multirow{2}{*}{ Constituents } & \multicolumn{2}{|c|}{ Composition (\%) } \\
\cline { 2 - 3 } & Whole fibre & Outer layer \\
\hline Cellulose & $90-95$ & 54 \\
\hline Waxes/fats & $0,4-1,0$ & 14 \\
\hline Pectic substances & $0,7-1,2$ & 9 \\
\hline Protein (nitrogen substances) & $1,1-1,9$ & 8 \\
\hline Ash & $0,7-1,6$ & 3 \\
\hline Organic acids & $0,5-1,0$ & - \\
\hline Other & 1,4 & 12 \\
\hline
\end{tabular}

Table 2.2: Composition of mature cotton fibre [Agrawal, 2005, Rouette (Ed.), 2001]

Sometimes a cotton fabric is mercerized. This is done to improve the quality of the fabric by changing the crystalline structure of the cellulose polymers. Mercerization is a treatment of cotton fabric under tension, with concentrated $\mathrm{NaOH}$ liquor. The aim of the treatment is a reduction of the dyeing costs and an improvement of the lustre. Due to mercerization the fabric can be dyed with less dyestuff to achieve the same colour. This is called the dye-efficiency. A reduction of $20 \%$ of the dye-concentration that is necessary to achieve the same colour is mostly realized. Mercerization after bleaching is most common, although it can be done also in other stages of the finishing process e.g. before desizing. The advantages of mercerization as improved handle of the fabric and dye efficiency have to be compared with the disadvantages as extra production step and thus costs. This is necessary because there is also a risk of decreasing the quality due to the formation of oxycellulose and hydrocellulose. The mercerization process is not a subject of this work, as it is not affected by bio-catalytic pretreatment. 


\section{Pre-treatment process steps}

\section{Singeing}

In the singeing process the protruding fibres are burned off the fabric. In the singeing unit the fabric is treated on both sides with gas burners. Before the actual singeing the fabric is cleaned from dust and loose cotton parts, which can cause fire. Immediately after singeing the fabric is guided in a liquor bath, that contains the desizing agents. The aim of immediate impregnation after singeing is besides efficiency the prevention of fire in cases of singeing problems. The main objective of singeing cotton is to achieve a smooth surface without protruding fibres. The protruding fibres will cause a diffusive light reflection when they have not been removed from the fabric and this will lead in that case to an uneven 'washed off look' of the surface of the fabric.

\section{Desizing}

The most common size on cotton fabrics is starch. Figure 2.5 shows the importance of starch as sizing agent related to other sizes.

Starch consists of two chemical components, amylopectin (80\%) and amylose (20\%). The chemical structure of starch is a polysaccharide composed by a condensation reaction of glucose monomers. The structures of amylopectin and amylose are shown in chapter 3 in figure 3.3 respective 3.4 .

Amylopectin consists of glucose monomers that are primarily linked by a (1-4) glucosidic bonds with $\alpha$ (1-6) linked side chains occurring at every $20-24^{\text {th }}$ glucose unit.

Amylose however is more a linear polymer consisting of glucose monomers linked by a (1-4) glucosidic bonds. Sizes contain often other products to improve the weaving efficiency, the socalled greasing waxes.

For desizing the enzyme amylase is used. a-Amylases hydrolyze randomly and are endo-acting on the $\alpha(1-4)$ bonds in the starch backbone [Cavaco-Paulo \& Guebitz (Ed.), 2003, Rouette (Ed.), 2001]. $\beta$-Amylases are not used for degradation of starch, because they only release maltose units from the chains ends of the starch polymer. However, these enzymes are not able to bypass branches in amylopectin. Amylases hydrolyze starch under different operating conditions like $\mathrm{pH}$, $\mathrm{t}$ and $\mathrm{T}$, depending on the enzyme selected. 


\section{Volume of sizes -- Global by Region}

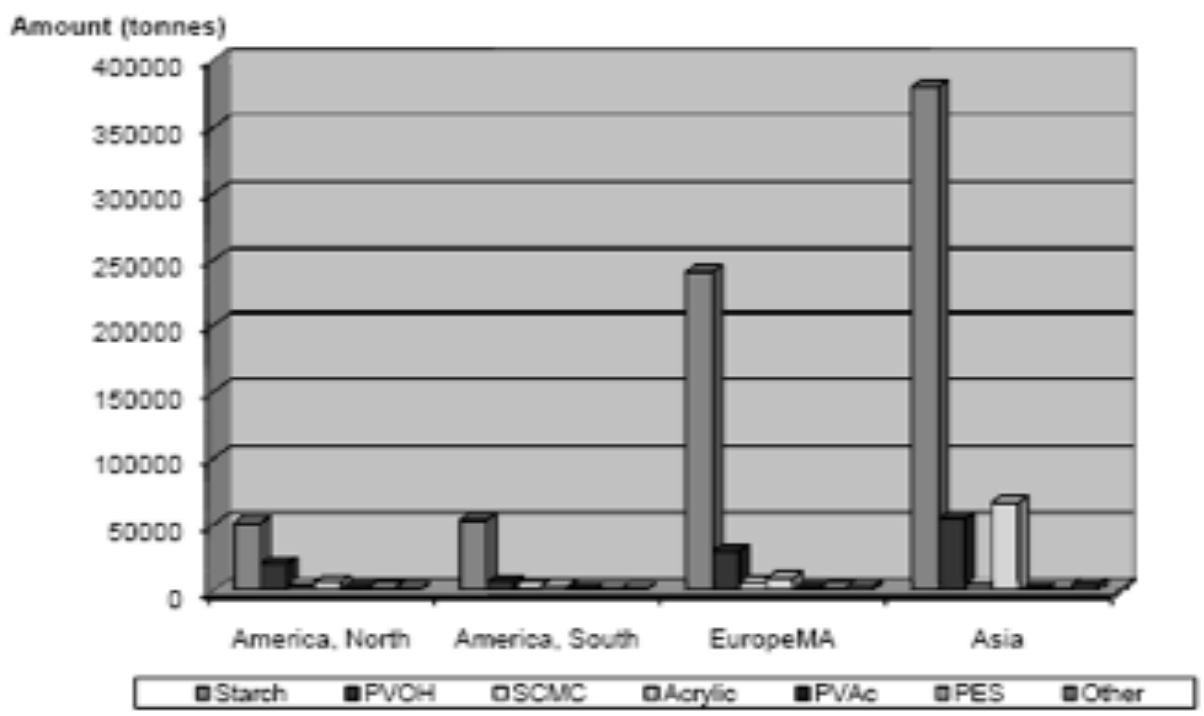

A rough picture for the year 2002

Figure 2.5: Global importance of starch (source: Guifang Wu/Novozymes, presentation at INTB/INPB (International Conference on Textile and Polymer Biotechnology)/Gent/Belgium/September 2009

Two process routes can be distinguished. The first is pad batch desizing, where the fabric is impregnated with a desizing liquor containing amylase. After an incubation time of $8-24$ hours the degraded size is rinsed out. The second process route is continuous desizing. Here the fabric is impregnated with a desizing liquor containing amylase. The fabric is lead into a steamer, at a temperature of $100^{\circ} \mathrm{C}$ and $100 \%$ relative humidity, after impregnation for the degradation of the size by the enzyme. Subsequently the fabric is rinsed. In both process routes the rinsing temperature is about $95^{\circ} \mathrm{C}$.

Other desizing processes are oxidative desizing, using peroxymonosulpheric acid or sodium bromide and desizing of water-soluble sizes by washing. The last process has a risk of catalytic damage of the cotton polymer and is used only in special situations e.g. when also polyvinyl alcohol as size is used.

\section{Scouring}

Scouring is the process step to destabilize and (partly) remove the primary wall of cotton. The goal of scouring is to make the cotton fibre accessible for water-solved products such as bleaching-agents, dyes, printing and finishing chemicals. Scouring saponifies fats and waxes, splits pectins and proteins and increases therewith to absorptive capacity of cotton. The destabilizing process of seed coat fragments starts during scouring. The continuous scouring process consists of impregnation with a strong $\mathrm{NaOH}$ solution $\left(25^{\circ}\right.$ Bé). After impregnation the fabric is incubated in a steamer during few $(1-3)$ minutes at $100^{\circ} \mathrm{C}$. In the steamer the cottonwaxes are degraded and liquefied. After the reaction in the steamer the products formed can be 
rinsed out and the out at $95-100^{\circ} \mathrm{C}$ and the primary layer is sufficiently removed. This scouring process is a so-called shock process, meaning that high concentrations chemicals are used during a short time. Characteristic for a shock-process is that in the short treatment time the fabric is not pre-heated before it is incubated. An alternative scouring process is kier-boiling at long liquor. This is a discontinuous process and is time consuming. This process is not a subject for further research in this work as it is a discontinuous treatment and its importance decreases annually.

\section{Bleaching}

Bleaching is the last step in the pre-treatment process before drying. The goal of the bleaching step is the realization of the required whiteness of the fabric. Also the fabric's hydrophilicity is for a major part realized during bleaching. It is assumed that the last part of the hydrophobic primary wall is removed during bleaching, resulting in improved hydrophilicity. The bleaching liquor contains $\mathrm{H}_{2} \mathrm{O}_{2}, \mathrm{NaOH}$ as bleaching activator and bleaching auxiliaries such as sequestering agents and $\mathrm{H}_{2} \mathrm{O}_{2}$ stabilizers. The whitening of the fabric occurs by oxidative discolourization of the natural colourants of cotton.

As a weak acid in aqueous solutions $\mathrm{H}_{2} \mathrm{O}_{2}$ dissociates only partly. The free acids have a very limited bleaching action. To produce an adequate bleaching effect $\mathrm{H}_{2} \mathrm{O}_{2}$ has to be activated. The activator to be used and the concentration depend on the fabric to be bleached. For cotton most often $\mathrm{NaOH}$ is used as bleach activator, based on economic arguments. In the bleaching liquor $\mathrm{H}_{2} \mathrm{O}_{2}$ has to be stabilized to prevent uncontrolled $\mathrm{H}_{2} \mathrm{O}_{2}$ decomposition.

The continuous bleaching step consists of a bleaching liquor impregnation step, followed by incubation for $10-20$ minutes in a steamer at $100^{\circ} \mathrm{C}$. After bleaching the fabric is rinsed and acidificated. Acidification is necessary to neutralize residual $\mathrm{NaOH}$, which causes a yellowing effect after drying when not properly neutralized. Higher quantities of $\mathrm{NaOH}$ before acidification can cause precipitation of sodium-acetate, which hinders even dyeing.

\section{Drying}

Finally the pretreated fabric is dried. This is normally done on drum dryer immediately after bleaching. A drum-dryer is a set of steam-heated metal drums on which the fabric is dried. The alternative for drying on a drum is drying on a stentor-frame. In a stentor the fabric is horizontally transported through a heating frame. Needle or clamps, which are connected to the chain, transport the fabric through the stentor. The fabric is dried by convective heat. After drumdrying the rest moisture is near $0 \%$ as it is impossible to control and adjust drum dryers to a preset rest moisture. During storage the natural water content of about $4-5 \%$ is realized under normal humid conditions after a relative short period ( $24-48$ hours).

\section{Pre-treatment performance indicators}

Cotton fabric is tested on several quality indicators after the pre-treatment process. The requirements for the pre-treated fabric depend on further processing and are related to the consecutive process. 
Therefore the treated fabric is evaluated for:

- size removal;

- hydrophilicity;

- whiteness of the fabric.

Machine-operators normally perform these tests. This organizational aspect requires fast and sufficient accurate tests. The advantage of in-production-testing is that process deviations are fast noticed and process adjustments can be carried out quickly.

\section{Colouring processes}

Fabrics are coloured by dyeing or printing after bleaching, unless a white fabric is needed.

In a dyeing process the dye is distributed uniform over the length and width of a fabric. This can be done on various dyeing equipment. The choice of dyeing equipment is often related to the volume of the batches and the choice of the dyes. The dyeing process as such consists of three steps: in the first step the dye is added to the fabric; during the second step the reaction of the dye with the substrate occurs to realize good dyeing properties and the third step is the washing off of the dye on the outer layer of the yarn.

Printing is in fact the same process as dyeing. The difference is that printed fabrics consist of more than one colour. The colours are locally added to the fabric, one by one, on one side using printing screens. Consequence of a one sided colour addition is normally a colour difference between the two sides of the fabric.

\section{Finishing}

In the finishing process the fabric gets its final properties. Textile finishing consists of two major finishing processes, mechanical and chemical finishing. Both processes aim to render the fabric the required functional properties. Mechanically achieved functionalities of textiles are shrinkageregulation by sanforizing, shine of the fabric and raising to increase volume of the fabric for thermal insulation etc. By chemical finishing the properties of the textiles are achieved by the use of chemicals. Here often properties like water- and oil resistance, flame retardancy etc. are applied to the fabric.

\subsection{Pre-treatment installed base}

To select a pre-treatment installed base for cotton the finisher has to choice of two primary options.

The first option is to treat the fabric in rope or full width form. In rope form the fabric is gathered loosely together in the form of a rope in the warp direction. The rope is guided through the equipment. Generally this process is more time consuming per metre fabric. Advantage of this process is that extra time that this treatment needs makes it possible that less harsh chemicals are used and therefore the fabric is less chemically damaged. Another advantage is that the width of a fabric is no restriction. During the pre-treatment of the fabrics in rope form there is a risk of the formation of creases and folds, which can be seen in the fabric after coloring and therefore this process is less often used. After treatment the ropes have to be detwisted before drying and further treatment. This results in extra handling and costs. In full width treatment the 
fabric is guided as a slab through the installed base. The production speed is higher, which results in more chemical damage. On the other hand there is no risk in the formation of creases and folds. Finally no extra handling for detwisting is involved. This research focuses on full width continuous pre-treatment of cotton fabric. Two reasons form the basis for this focusing. The first reason is that in rope form the pre-treatment time is no restrictive element due long reaction times in the J-boxes and thus time is here not the limiting factor for enzymatic treatment. Second argument for focusing on full width processing is that the majority of continuous cotton finishing is based on full width pre-treatment.

The second option is the choice for continuous or discontinuous pre-treatment. In continuous pre-treatment the fabric is guided into the installed base and passes subsequently all process steps after each other in the different parts of the equipment. This option is further subdivided in full continuous and pad batch-hot bleach pre-treatment. Discontinuous pre-treatment is the way of processing in which the fabric is guided into the installed base and the process steps are all carried out in the same part of the fabric. Consequence is that more time is needed for processing. After every step the process is stopped to prepare the next step. Time is lost by adding chemicals or by changing temperature. Advantage of this type of processing is that variations in process-time form no technical restrictive factor.

The two primary options give four alternative main process-routes for pre-treatment of cotton. In the following the four main routes are briefly discussed.

\section{Rope-discontinuous processing}

Rope-discontinuous treatment is applied when small batches have to be produced. The capital investment in this installed base is relative low. This processing is flexible concerning reaction times because the fabric-ends are sewed together to form a loop in the installed base. This loop is rotated in warp direction through the equipment. Drawbacks of this process are reproducibility and risk of rope folds as stated before. Well-known equipment for this treatment is a winch and a jet.

\section{Rope-continuous processing}

Rope-continuous processing is very well suited for large batches and high volumes of fabrics. Water and energy efficiency of this process is at discussion due to high liquor to cloth ratio and high process temperatures. The liquor to cloth ratio (LCR) is the ratio of the weight of the fabric

and the quantity water used for the treatment. The large quantity fabric that is simultaneously processed in this equipment makes process changes costly and time consuming. The installed base consists of a number of J-boxes and U-boxes in series. The major drawbacks of this process are the risk of rope folds and inflexibility process changes.

\section{Full width-discontinuous processing}

Pre-treatment of cotton on full width is by far the most applied pre-treatment process. Full widthdiscontinuous processing is chosen when small batches are processed. The drawbacks are reduced reproducibility and no efficient water and energy consumption, caused by a high LCR. This process gives unavoidable seconds in the form of start and end of the batch as a jigger is 
used. Advantage of this production method is the flexibility, because each batch has to be produced separately.

\section{Full width-continuous}

Full width-continuous pre-treatment process is most common and widely spread. In full widthcontinuous pre-treatment there are two processing options as mentioned before [www.Benninger.ch]. These options are:

- full continuous pre-treatment;

- pad batch-hot bleach pre-treatment.

In this work the previous mentioned options on full width pre-treated fabric will be explored. The first option is full width-full continuous pre-treatment of cotton. In this process the fabric is in one operation singed, desized, scoured, bleached and dried. This results in three wet pre-treatment process steps, each with its impregnating compartment, reaction chamber and rinsing compartments. This installed base is schematically drawn in figure 2.6. A variation on this process is semi continuous. In that case installed base has only one steamer and the fabric is guided two or more times through the installed base without the necessity of reaction time between the treatments. The process time is a function of the fabric capacity (volume) and the fabric velocity. So in the case that a new process is developed, which prescribes extra reaction time this means that the capacity of the installed base is reduced. On the other hand it can also be concluded that the combination of process steps results in increased output. The quality of the fabric is reproducible and water and energy consumption is generally more efficient than other processes as discontinuous and rope-continuous treatment.

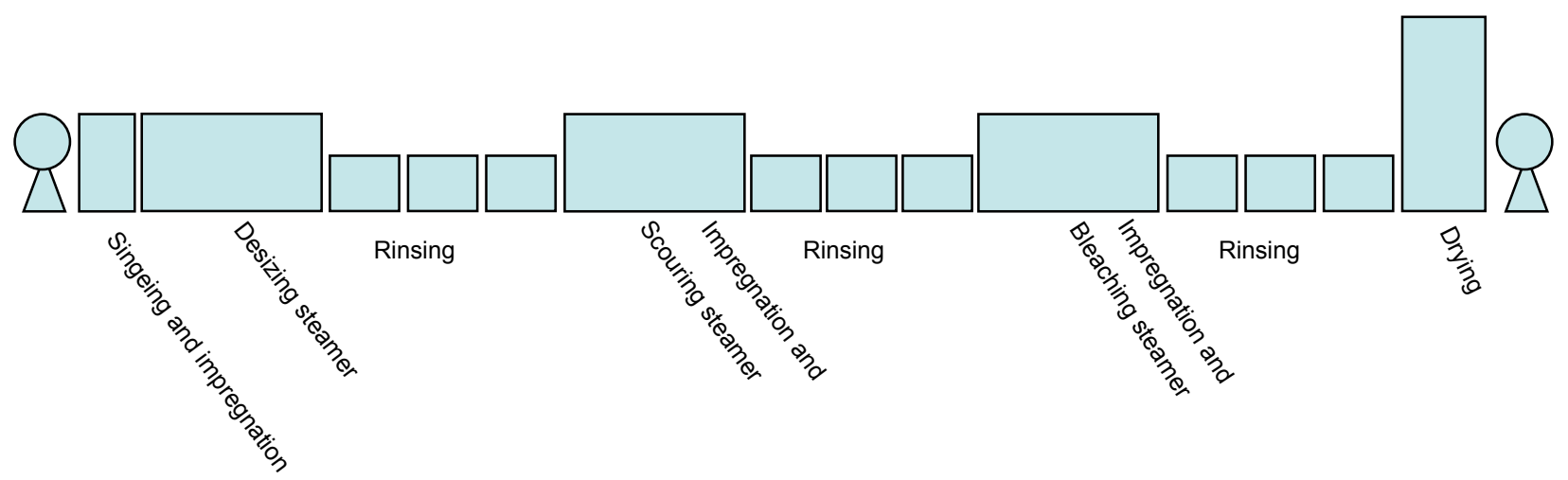

Figure 2.6: Schematically full continuous installed base

The second option is full width pad batch-hot bleach. This process is a variation on full continuous. The difference is that after singeing and impregnation with the desizing liquor the batch is stored on an A-frame for some hours. An A-frame can contain a fabric length of several thousand metres. During the storage time the enzymatic reaction takes place. This installed base is schematically drawn in figure 2.7. The fabric is rinsed, bleached and dried after the enzymatic reaction. The concentrations chemicals, that are used for bleaching is higher in this 
process than it is the case in full continuous pre-treatment processes. The extra chemicals are necessary to obtain sufficient hydrophilicity and whiteness as the scouring step is passed over. In fact the 'scouring' step is incorporated in the bleaching step. Therefore extra bleaching-agents are added to the bleaching impregnation liquor for combined scouring and bleaching. The disadvantage of this process is, when it is compared to full continuous processing, that the increased concentration chemicals result in higher damage of cotton fibres and fabrics and higher cost of chemicals. The advantage of this process is that a more flexible installed base can be used and less capital investment is necessary.
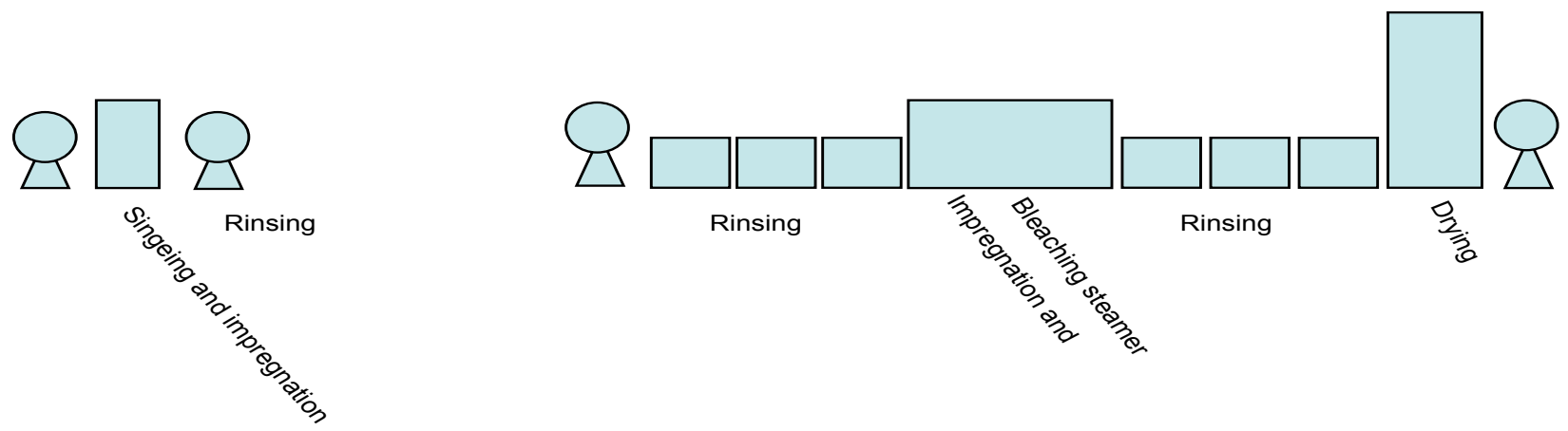

Figure 2.7: Schematically full width - pad batch hot bleach installed base

It is impossible to design one general pre-treatment process for cotton, due to different pretreatment options based on installed base only. The selection of an installed base as such depends on the fabrics to produce, weight of the fabric, qualitative requirements for further processing, availability of water, energy and chemicals. This leads to almost only unique installed base and thus unique processing for the pre-treatment of cotton.

In this research the focus is on full continuous and pad batch-hot bleach pre-treatment of cotton fabrics. It is assumed that more than $70 \%$ of the globally continuously pre-treated cotton is produced on full continuous and pad-batch- hot bleach installed base.

The textile industry consumes for rinsing purposes large quantities water, energy and chemicals resulting is high volumes of wastewater. However nowadays mankind focuses on responsible environmental behavior. From this focus research on renewable products, biopolymers, sustainable processing, application of biomass as energy source and other research fields is started. The connection between these research fields is the upcoming scarcity of raw materials and fossil fuels. For many years researchers in knowledge institutes, textile industry, but also manufacturers of textile equipment, have been working on improvement of sustainability. $A$ boost in this development and the public debate on this topic came from the publication of 'The inconvenient Truth' by AI Gore [Gore, 2006]. The importance of this publication is more the start of the public debate on this topic than the scientific validation. Nevertheless Gore urged publicly for increased thinking for sustainability. This debate will also force the textile industry to reconsider high consumption of scarce products. To produce $1 \mathrm{~kg}$ cotton for pre-treatment, dyeing and finishing processes the water consumption of about $40 \mathrm{~kg}$. Over $90 \%$ of this water consumption is used for rinsing at boiling temperature and therewith a lot of energy is used only 
for rinsing. During rinsing impurities from textiles, not fixed dyes and other finishing chemicals are disposed from the fabric to the wastewater. The large consumption of water and energy and production of wastewater has to be decreased. Not only in terms of costs but also in terms of improvement of sustainability of textile production.

A lot of research is done to improve sustainability in textile processing. Researchers have been working on identifying enzymes for textile processing, reduction of process costs by using catalysts, reduction of concentrations chemicals. Despite all this research a drastic improvement of sustainability is not yet realized. The major hurdle for implementation of new processes is the up scaling from lab to industrial scale [Bouwhuis et al. 2007, 2009].

The answer to these questions has to lead to the development of an innovative sustainable industrial scale process for pre-treatment of cotton by using (bio) catalysts and ultrasound. Critical success factors are identification of options, implementation and interaction of chemicals, fabric and installed base. Therefore knowledge institutes, like academic and applied universities, and industry have to work closely together to achieve improved environmental processing under industrial requirements as capacity, quality and costs. 


\section{References}

Agrawal, P.B., "The performance of cutinase and pectinase in cotton scouring", ISBN 90-3652243-9, Thesis University of Twente, the Netherlands, 2005

Benninger, Ben Bleach http://www.benninger.ch , last time visited August, $7^{\text {th }}, \mathbf{2 0 1 0}$

Bouwhuis, G.H., V.A. Nierstrasz and M.M.C.G. Warmoeskerken, "The use of (bio)catalysts and ultrasound in the pretreatment of cotton: Application on industrial scale as a sustainable process", Proceedings of the 7th AUTEX Conference, Tampere, Finland, 26-28 June 2007

Bouwhuis G.H., B. Dorgelo and M.M.C.G. Warmoeskerken, "Upgrading from lab scale to pilot scale in the use of (bio)catalysts for sustainable pre-treatment of cotton fabrics on industrial scale: A matter of energy", Proceedings of the $9^{\text {th }}$ Autex Conference, p241-p249, ISBN: 978975-483-787-2, Izmir, Turkey, Mai 26-28, 2009

Cavaco-Paulo, A. and G.M. Gübitz, “Textile processing with enzymes”, ISBN 185573610 1, Woodhead Publishing, 2003

Gore, A., "An Inconvenient Truth", ISBN 10:90 2907867 7, (Dutch translation) J.M. Meulenhof BV / Amsterdam, 2006

Kooistra K., and A. Termorshuizen, "The sustainability of cotton", Science Shop Wageningen UR, April 2006

Koslovski Hans-J., Chemiefaser Lexikon, ISBN 978-3-87150-876-9, Deutscher Fachverlag $\mathrm{GmbH}, 2006$

National cotton council, home page http://www.cotton.org/pubs/cottoncounts/story/

Miyake, H., Y. Gotoh, Y. Ohkoshi and M. Nagura "Tensile properties of wet cellulose", Polymer Journal, Vol. 32, No. 1, pp 29-32, 2000

Organic cotton exchange, global productionhttp://www.ota.com/organic/mt/organic cotton.html last time visited: June, $6^{\text {th }}, 2010$

Rouette, H.K., "Encyclopedia of Textile Finishing”, ISBN 3-540-65031-8, Springer Verlag Berlin/Germany, 2001

Swicofill http://www.swicofill.ch/products/001cotton.html Ist time visited: June $6^{\text {th }}, \mathbf{2 0 1 0}$ Unctad market information in the commodities area. http://unctad.org/infocomm/anglais/cotton/market.htm last time visited August $7^{\text {th }}, \mathbf{2 0 1 0}$

Wakelyn, P.J. and A.D. French (Ed.), "Cotton fiber chemistry and Technology", ISBN 13:978 1 42004587 1, CRC Press, Boca Raton/USA, 2007

WWF report 2406, "Cleaner, greener cotton", published October 2007 http://assets.wwf.ch/downloads/bericht cleaner greener cotton in english .pdf last time visited November $24^{\text {th }}, 2010$ 



\section{Enzymatic desizing and scouring}

In this chapter the enzymes for one bath desizing and scouring are selected. The enzymes are amylase, cutinase and pectinase and they form the enzyme cocktail. The process conditions and the performance of the enzyme cocktail are evaluated for pad batch and continuous processing. A substantial reduction of the reaction and the rinsing temperature is realized in lab scale conditions. For seed coat fragment removal from the cotton fabric the enzymes cellulase and xylanase have been evaluated in combination with the enzyme cocktail containing cutinase and pectinase. No improvement in seed coat fragment removal with the enzymes cellulase and xylanase has been noticed.. It has been concluded that it is not possible to remove the seed coat fragments without additional bleaching after scouring. 


\subsection{Introduction}

The aim of desizing and scouring is the removal of starch, the cuticle and the primary wall. In chapter 2 it has been explained that this has to be done before bleaching. The aim of this work is to replace the two-step conventional high temperature desizing and scouring with amylase and $\mathrm{NaOH}$ by a one step enzymatic desizing and scouring process at low temperature. It is known that enzymes catalyze chemical reactions at low temperature and that enzymes are substrate specific. This leads to the assumption that enzymes, applied in industrial processes, enable a major temperature reduction and form no undesired side-products. Therefore enzymes have the potential to improve the sustainability of the process.

\subsection{Enzymes}

The word enzyme comes from the Greek zymae that means 'sour dough'. Enzymes are also called biocatalysts. Enzymes catalyze biochemical processes. The catalysis can refer to either hydrolytic or synthetic reactions. Organic nature can only exist because very specifically tailored enzymes catalyze natural processes. Enzymes are proteins that consist of amino acids. Each enzyme has a specific amino acid sequence. The spatial arrangement of enzymes is typical, and occurs through helical segments, folding leaf structures and intra-molecular associations. Figure 3.1 shows the three-dimensional structure of the enzyme amylase.

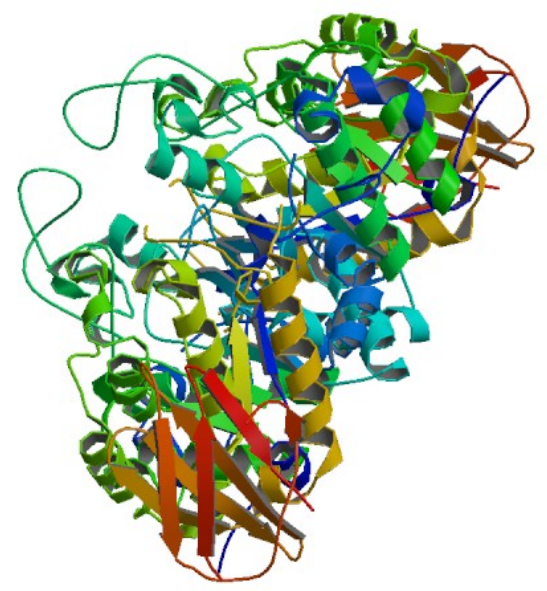

Figure 3.1: Assumed biological model alpha amylase (3.2.1.54) (www.proteindatabank)

The surface is mostly hydrophilic, which means a good interaction with water. The inner part of the enzyme contains a crevice. Inside this crevice is an active site, a small region with the shape and chemical composition necessary to bind the substrate and catalyze the appropriate reaction. The active site acts like a lock into which only a specific key, the substrate, can fit. Various acidic, basic and neutral amino acid side chains enable the to orient to the enzyme's active site to support a maximum interaction with the substrate. 

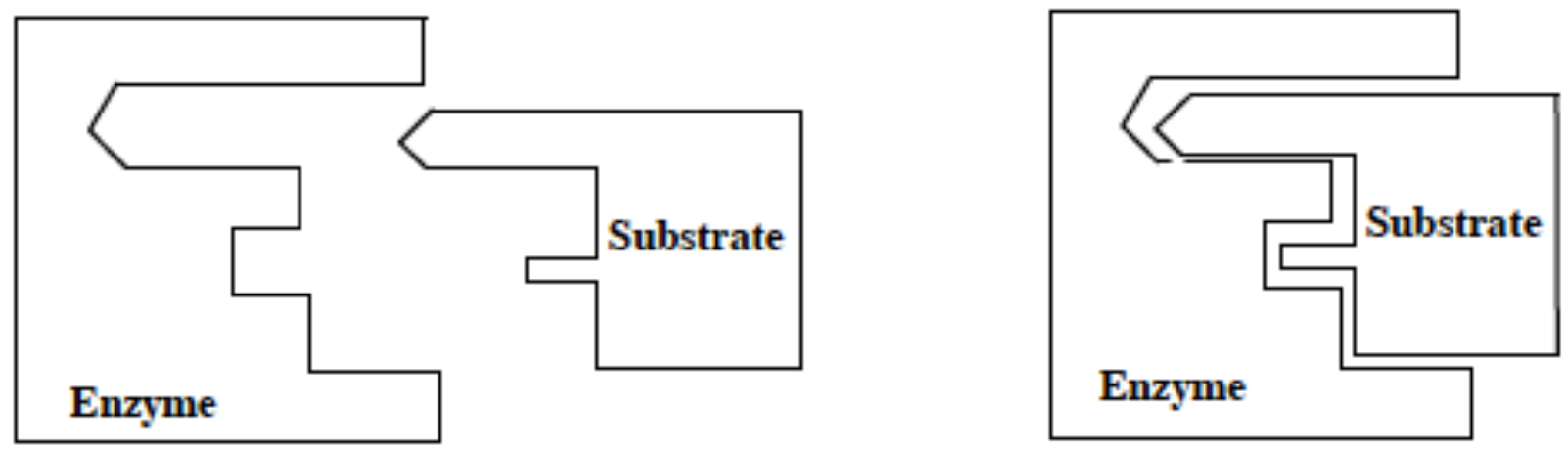

Figure 3.2: Schematic representation of the lock-key principle of enzymatic mechanism as first represented by E.Fisher in 1894 [Lopez, www.sc.ehu.es]

Enzymes that are applied in the textile industry are solved in water and added to the bath, in which the substrate is treated. This treatment consists of three different steps:

1. The mass transfer of the enzyme from the bath (bulk) to the substrate;

2. The enzymatic reaction;

3. The mass transfer of the enzyme and product formed in the enzymatic reaction from the fabric to the bulk.

In chapter 5 the steps 1 and 3 , describing the mass transfer of the enzyme from the bulk into the fabric vise versa will be discussed.

In the enzymatic reaction however the first step is the formation of an enzyme-substrate complex, which depends, besides the substrate and enzyme concentration on the temperature and $\mathrm{pH}$. So the concentration, temperature and $\mathrm{pH}$ form the operating window for the enzyme performance.

Enzymatic reactions begin when the enzyme is adsorbed at the substrate and the enzyme migrates with the active site to the substrate to form an enzyme-substrate complex. The enzyme and substrate are held together by hydrogen bonds and weak intermolecular attractions, so no covalent bonds are formed. The enzymes-substrate complex shows a precisely defined arrangement, where the appropriately positioned atoms in the active site of the enzyme facilitate a chemical reaction of the substrate molecule and the enzyme. After the reaction the enzyme is separated from the product. The most simple and frequently used description of the reaction pattern is given below.

$S+E_{\longleftarrow}^{\stackrel{k_{1}}{\longrightarrow}}[E S] \stackrel{k_{3}}{\longrightarrow} P+E$

$\mathrm{E}, \mathrm{S}$ and ES represent respectively the concentrations of the enzyme, substrate and enzymesubstrate complex. $\mathrm{k}_{1}$ is the adsorption constant and $\mathrm{k}_{2}$ is the desorption constant. The reaction rate constant is $\mathrm{k}_{3}$. The kinetics of enzymatic reactions have been studied extensively by Michaelis and Menten [McMurry \& Fay, 2008, Rouette (Ed.), 2001, Engbersen \& de Groot, 
2004]. In their model they assume a reversible formation of the ES-complex that after the reaction forms a product and enzyme. The so-called Michaelis-Menten constant $\mathrm{K}_{\mathrm{m}}$ is:

$$
K_{m}=\frac{k_{2}+k_{3}}{k_{1}}
$$

This constant can be seen as the rate between the decomposition of the complex ES due to desorption and reaction and the formation of ES due to adsorption. Between the conversion rate (v) of the substrate and the concentration of the substrate [S] consists the following relation:

$$
v=\frac{V_{\max }[S]}{K_{m}+[S]}
$$

There $\mathrm{V}_{\max }$ is the maximum rate of conversion of the substrate at a known concentration of enzymes. [S] is the concentration of the substrate. The reaction rate increases with increasing concentration of the substrate until the available enzymes become limiting. In that case the reaction rate becomes constant. $\mathrm{K}_{\mathrm{m}}$ can be calculated by first measuring $\mathrm{V}_{\max }$ and than measuring $v=1 / 2 V_{\max }$. For that situation the following relation is valid and $K_{m}$ can be calculated:

$$
v=1 / 2 V_{\max }=V_{\max } \frac{[S]}{K_{m}+[S]} \Rightarrow K_{m}=[S]
$$

This reaction rate equation is used to calculate the maximum rate substrate-catalysis at a known concentration enzyme.

An enzyme contains weak and strong interactions in its three-dimensional structure. In the spots with weak interactions the temperature and chemicals can cause changes in the molecular structure and the unfolding process, distorting the polypeptide conformation that leads to inactivation of the enzyme.

Each enzyme has a characteristic $\mathrm{pH}$ at which the catalytic activity is highest (the optimum $\mathrm{pH}$ ) and with a minimum and maximum $\mathrm{pH}$ value, beyond which the enzyme does not function. The temperature effects the folding of the enzyme and influences therewith the performance.

Enzymes are classified in six classes for their specific reactions [Cavaco-Paulo and Guebitz (Ed.), 2003]:

1. oxidoreductases, enzymes that catalyze oxidoreductase reactions;

2. transferases, enzymes that transfer a group;

3. hydrolases, enzymes that catalyze cleavage of $\mathrm{C}-\mathrm{O}, \mathrm{C}-\mathrm{N}, \mathrm{C}-\mathrm{C}$ and other bonds;

4. lyases, enzymes that cleave $\mathrm{C}-\mathrm{C}, \mathrm{C}-\mathrm{O}$ and $\mathrm{C}-\mathrm{N}$ and other bonds by elimination, leaving double bonds or rings, or adding groups to double bonds;

5. isomerases, enzymes that catalyze geometric and structural changes within one molecule;

6. ligases, enzymes catalyzing the joining of two molecules. 
For cotton pre-treatment enzymes of the group 3, the so-called hydrolases are mainly used. The enzymes from this group catalyze hydrolytic reactions. Well-known members of this group are peptidases, esterases, glucosidases and phosphatases. Enzymes accelerate biochemical reactions, both hydrolysis and syntheses. Enzymes have important advantages compared to chemical catalysts. The advantages are [Cavaco-Paulo and Guebitz (Ed.), 2003]:

- enzymes can speed up chemical reactions with a factor of $10^{6}$ up to $10^{13}$;

- enzymes react substrate specific and side-products are rarely formed;

- enzymes catalyze reactions under mild conditions, contrary to chemical catalysts that often acquire high temperature and very high or low $\mathrm{pH}$ values.

Enzymes are good candidates to be used in pre-treatment processes because these advantages. For this reason enzymes are frequently studied for application in pre-treatment processes for cotton [Cavaco-Paulo and Guebitz (Ed.), 2003]. However hardly any new industrial application for pre-treatment processes, besides the well known desizing with enzymes, has been reported. Enzymatic application is only of interest for the industry if no extra process steps are necessary, when process steps can be combined and when the installed base has not to be changed. This work is focused on the application of enzymes in existing industrial process steps desizing and scouring and the aim is to combine the process steps of desizing and scouring into one single step.

\subsection{Candidate enzymes in pre-treatment processes for cotton}

Enzymes are used in textile industry for more than 100 years. In 1920 the first use of bacterial amylase for desizing has been reported [Buchholz et al, 2005]. Preceding the use of bacterial amylase, barley, that contains amylase, has been used for desizing starch-strengthened fabric. Since 1950 the enzyme amylase is used for desizing on industrial scale. In the last decades of the $20^{\text {th }}$ century other enzymes are found as candidates for pre-treatment of cotton. The following enzymes have been studied for pre-treatment of cotton:

- amylase [Rouette 2001];

- cutinase and lipase, for destabilization of the cuticle of cotton [Agrawal 2005, Agrawal et al. 2007, Agrawal et al. 2008 and Yan et al. 2009];

- pectinase, acidic (polygalacturonase PG) and alkaline pectinase (pectate lyase $P L$ ) for destabilization of the primary wall [Agrawal 2005, Agrawal et al. 2008, Hebeish et al. 2009, Tzanov et al. 2001];

- cellulase, for destabilization of the primary wall [Anis et al. 2002, Bach et al. 1993];

- glucose-oxidase for in situ production of $\mathrm{H}_{2} \mathrm{O}_{2}$ [Eren et al. 2009, Ramadan 2008];

- catalase [Cavaco-Paulo and Guebitz (Ed.) 2003];

- xylanase for degradation of seed coat fragments [Cziszar et al. 2006, 2007].

\section{Amylase}

From chapter 2, figure 2.5 it is clear that starch is the most used sizing agent. For the removal of this product amylase is commonly applied. Starch is a mixture of two similar carbohydrates of different molecular size and shape, amylose (20 - 30\%) and amylopectin (70 - 80\%). 
The chemical structure of amylose is a non-branched polymer consisting of $\alpha(1-4)$ linked glucosidic units, bridged by the oxygen atom. Amylose (figure 3.3) forms a colloidal system in hot water.

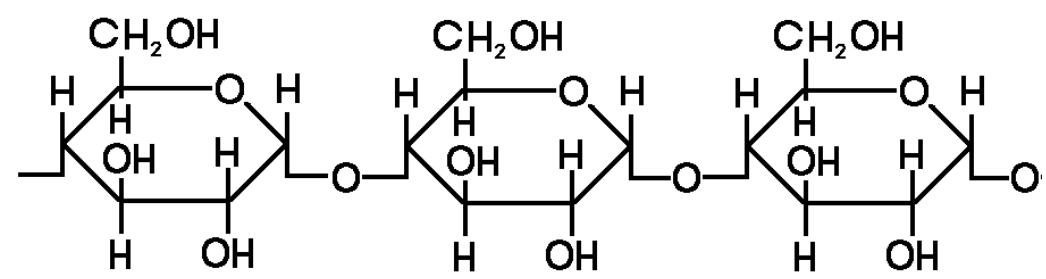

Figure 3.3: Amylose (members.home.nl)

Amylopectin (figure 3.4) is branched, high molecular and insoluble in water.

Amylopectin is every $25-30$ units branched. The backbone consists of a (1-4) linked glucosidic units and the branches are $\alpha(1-6)$ linked glucosidic units.

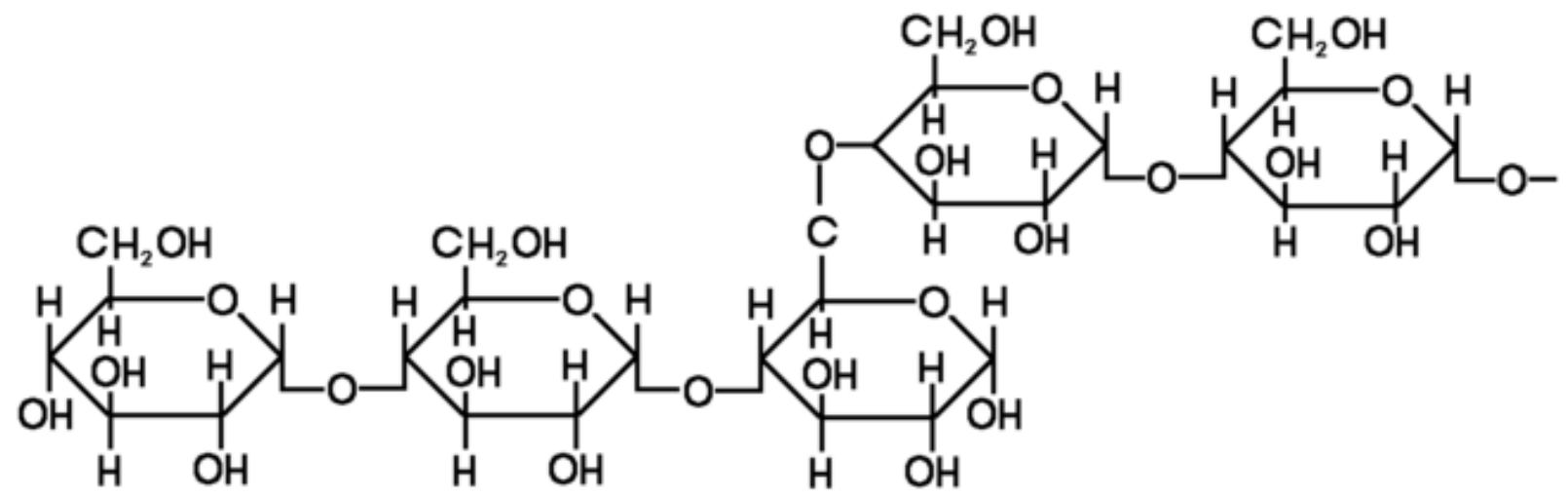

Figure 3.4: Amylopectine (Wikipedia.nl)

The so-called $\alpha$-amylase is specific to a (1-4) glucosidic bonds in the starch backbone and cleaves endo-acting the starch molecules step by step into glucose, which is soluble. Due to the specifity of $\alpha$-amylase to $\alpha$ (1-4) glucosidic bonds it does not damage cellulose, which has $\beta$ (14) glucosidic bonds. Nowadays $\alpha$-amylase is commercially available for different desizing processes regarding time, temperature and $\mathrm{pH}$. It is currently the most applied desizing agent.

\section{Cutinase and lipase}

The cuticle is the outermost layer of cotton (figure 2.3). It protects the fibre against dehydration and chemical and biological attacks. In cotton scouring the cuticle is the first layer of the fibre to be removed, before the primary wall can be accessed. The cuticle consists of primary alcohols, higher fatty acids, hydrocarbons, aldehydes, glycerides, sterols, acyl components, resins and the waxes cutin and suberin [Agrawal 2005, Kolattukudy et al. 2001]. The waxy constituents have 
melting points varying from $64-214^{\circ} \mathrm{C}$. For industrial processing sufficient wax melting is realized at $70-75^{\circ} \mathrm{C}$ and about $50 \%$ of the cotton wax can be saponificated [Rouette 2001]. The rest of the wax is insoluble and can only be emulsified. The waxy constituents contribute about 0,4$1,0 \%$ of the dry weight of the cotton fibre (see table 2.2) and give high hydrophobicity to the cotton fibre. Destabilization of the cuticle is of utmost importance to enable pectinase to degrade pectin in the primary wall, below the cuticle.

For wax removal three enzymes from the carboxylic ester hydrolasis group (E.C.3.1.1) have been evaluated:

1. esterases (EC 3.1.1.1) as they hydrolyze ester bonds by addition of a water molecule; Esterases show less activity to the aggregated form of its substrate, the so-called soluble form, and therefore this candidate is not selected;

2. cutinase (EC 3.1.1.74), being a lipophilic enzyme. Cutinase shows high activity to the aggregated form of the substrate;

3. lipase (EC 3.1.1.3), which is a lipophilic enzyme, shows also high activity to the aggregated form of the substrate.

Cutinase has the following advantages over lipase:

1. cutinase needs no $\mathrm{Ca}^{2+}$ ions for its hydrolytic activity. Contrairy to lipase that needs $\mathrm{Ca}^{2+}$ ions for activation. This differerence between cutinase and lipase is important, as it is known from literature [Agrawal, 2005] that the pectinase performance can be hindered by the presence of $\mathrm{Ca}^{2+}$ ions;

2. lipases require interfacial activation at the lipid/water interface. Interfacial activation is the extra energy necessary for positioning the active site of the enzyme to the substrate and to start the hydrolyzis of cotton-waxes. The enzyme cutinase does not need this activation;

3. cutinase showed in earlier research good cuticle degradation and increased wetting properties of the fabric [Agrawal 2005, Agrawal et al. 2007, 2008, Yan et al. 2009].

Since it is important that the enzyme solution has acces to all fibres in the fabric it is necessary to use a surfactant as wetting agent. The wetting agent enables the enzyme solution to penetrate deeply into the pores of the fabric. Cotton of which the waxy cuticle has been removed with n-hexane extraction shows the same contact angle of $66-68^{\circ}$ as cotton where the cuticle is removed by cutinase and surfactant [Agrawal 2005]. In this work the surfactant Triton $X 100$ is not used, because the use of this surfactant is prohibited in most applications as it consists of octylphenol ethoxylates (OPE). OPE's are classified in detergent guidelines as suspected carcinogenic. Furthermore the biodegradability according to GOTS and Ökotex guidelines of Triton X 100 is not sufficient for the concentrations that are used in these applications. So it has been decided to explore the surfactant Tanaterge Advance, which has been recommended by Tanatex [private communications with Mr. de Wit from Tanatex/Ede/the Netherlands 15-7-2010]. Tanaterge Advance is an alkoxylated fatty alcohol wetting agent. The compatibility of this surfactant with the enzyme has been determined experimentally in $\S 3.7$. The enzymes and surfactant are supplied by Tanatex Chemicals in Ede/the Netherlands. 
Cutinase is used in this work for degradation of the cuticle due to advantages over lipase and its performance in the degradation of the cuticle as showed by other researchers [Agrawal 2005, Yan et al. 2009]. The next step in the pre-treatment process is the removal of the hydrophobic primary wall before cellulose is accessible for bleaching agents.

\section{Pectinase}

Pectinase is a candidate-enzyme for degradation of the primary wall in the cotton fibre. The primary wall has a thickness of $0,5-1,0 \mu \mathrm{m}$ and consists of amorphous cellulose and noncellulosic components as pectins, waxes, proteins and natural colouring matter. Pectin is an acidic polysaccharide and gives the cotton fibre its strength, interconnects cellulosic fibrils and plays an important role in water transport in the fibre. In cotton two types of pectin are distinguished:

- esterified pectin;

- non-esterified pectin.

Esterified pectin consists of high methylated pectins and forms the so-called hairy regions. The hairy constituents of pectin are oligosaccharide side chains. These methylated side chains have a tendency to become de-esterified in humid atmosphere at relative low temperature. Pectinase has the potential to destabilize the primary wall by cleavage of the pectin chains via $\beta$ elimination. The $\beta$-elimination mechanism results in the formation of a double bond between $\mathrm{C} 4$ and $\mathrm{C} 5$ at the non-reducing end and cleaving pectins to water-soluble oligosaccharides [Bach \& Schollmeyer, 1993].

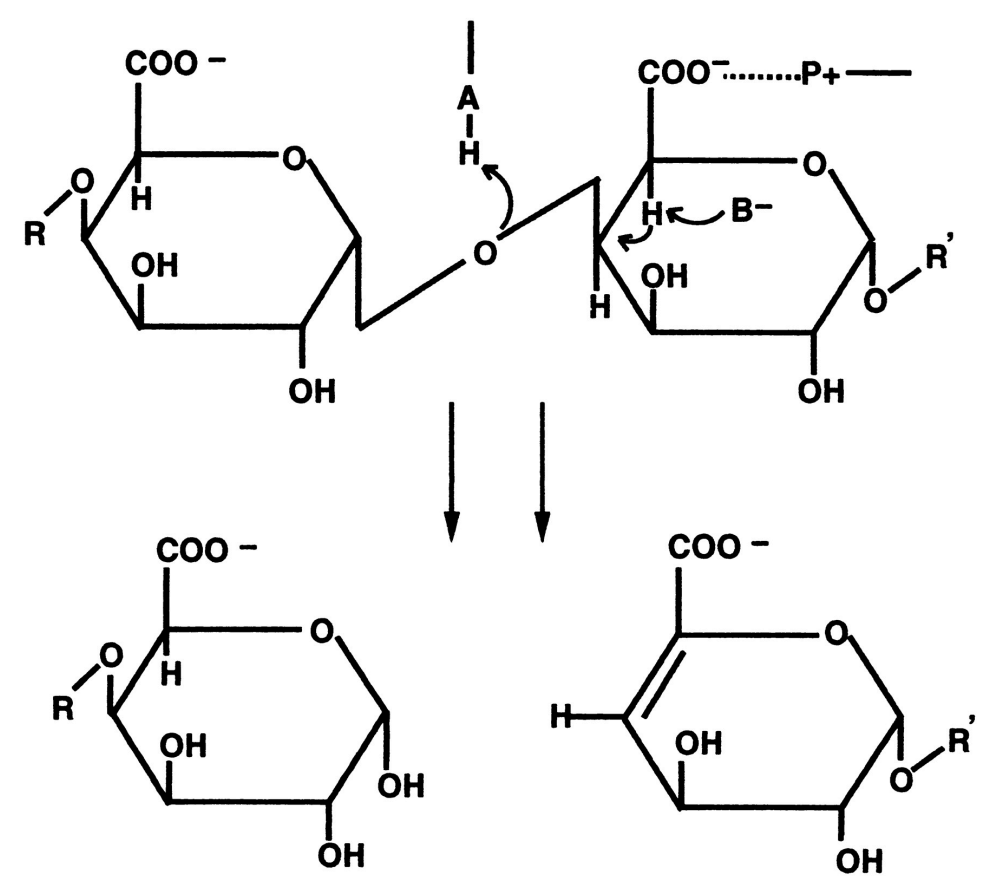

Figure 3.5: Schematic diagram of $\alpha$ (1-4) polygalacturonic acid cleavage by a $\beta$-elimination mechanism [Herron et al., 2000] 
Agrawal et al. reported the boosting effect of cutinase for the degradation of the primary wall with pectinase [Agrawal 2005, Agrawal et al. 2007, 2008]]. Removal of the cuticle, the hydrophobic barrier of the primary wall, opens the door for pectinase-activity for destabilization of the primary wall by degradation of pectin. The pectinase used in this work is an alkaline pectinase, which has the advantage over acidic pectinase that one-bath scouring is an option, because the optimum $\mathrm{pH}$ of the alkaline pectinase and cutinase is compatible. Also the pectin removal from the cotton fibre with the use of the alkaline pectinase is, with a removal degree of $76-83 \%$ better than acidic pectinase that removes maximum 52\% of the pectin [Agrawal 2005]. So the alkaline pectinase shows substantial better removal of the pectin in cotton, it shows good performance at $\mathrm{pH} 8$ at a low temperature of $30^{\circ} \mathrm{C}$ and is commercially available. Therefore this pectinase is selected as candidate for one-bath enzymatic pre-treatment of cotton.

\section{Cellulase}

The enzyme cellulase is known for its performance in bio-polishing, aging processes and depilling. In these applications cellulose is hydrolyzed by the synergistic action of endo- $\beta-(1-4)$ glucanases, cellobiohydralases and $\beta$-glucosidases. It is suggested that endo-glucanase cleaves cellulose into smaller ends. These smaller ends are subsequently hydrolyzed by the cellobiohydralases, which are exo-acting. It is also believed that the cellobiohydrolase enzyme erodes the crystalline regions of cellulose and thus making cellulose more susceptible for endoglucanase attack [Cavaco-Paulo \& Guebitz (Ed.), 2003].

Besides the previous described application of cellulase researchers have studied the performance of cellulase in pre-treatment of cotton. These studies focused on two aspects for the use of cellulase in cotton pre-treatment:

1. degradation of seed coat fragments [Tavcer, 2008];

2. degradation and destabilization of the primary wall [Ahlawat et al. 2009, Anis \& Eren, 2002, Csiszar et al., 2006, Karapinar \& Sariisik, 2004].

A weight loss of more than $10 \%$ compared to the weight loss after scouring has been found [Bach \& Schollmeyer, 1993, Sangwataranoy \& Choomukulpong, 2003]. It is believed that cellulase treatment removes hairs from seed coats more than that they degrade the seed coat fragments as such. Despite some degradation of seed coat fragments it is confirmed in the afore mentioned studies that neither enzymatic nor conventional scouring, completely removes seed coat fragments. In the best case these treatments will enable the removal of seed coat fragments in further treatments [Tavcer, 2008]. The risk in applying cellulase for the removal of the seed coats is the degradation of the cotton fibres in the fabric. The cellulase enzyme has a $\mathrm{pH}$ optimum in acidic medium. This means that also an extra pre-treatment step will be necessary. For the removal seed coat fragments the performance of cellulase will be evaluated. Holocellulose fibres are often attached to seed coat fragments. These fibres are twisted in the yarn, resulting in a 'binding' of the seed coat in the yarn. Cellulase could degrade the holocellulose fibre on the seed coat. The mechanical energy applied during wet processing could then induce the removal of the seed coat. To evaluate this hypothesis separate 
experiments with cellulase on pure seed coat fragments will be carried out. Due to risk of cellulose degradation by cellulase [Anis \& Eren, 2002], as mentioned before, it is decided that cellulase is not selected as a candidate for pre-treatment of cotton.

\section{Protease}

The enzyme protease cleaves peptide bonds. The proteins in cotton are embedded in the primary wall and the concentration of the proteins in the primary wall is in the same order of magnitude as that of pectin (table 2.2). The proteins in cotton are so-called glycoproteins, which consists for $>65 \%$ of carbohydrates. Researchers have evaluated the enzyme performance of protease and protease combined with pectinase and cellulase for the degradation of the proteins in the cotton fibres. It is reported that the use of enzyme protease increases the brightness of cellulose. The enzyme cocktail protease/pectinase and protease/cellulose shows less hydrophilicity than the experiments, where pectinase and cellulase have been used [Karapinar \& Sariisik, 2004, Sangwatanaroy \& Choonukulpong, 2003]. It is therefore concluded that protease has no added value in bio-scouring.

\section{Glucose-oxidase}

The glucose-oxidase enzyme catalyzes the production of $\mathrm{H}_{2} \mathrm{O}_{2}$ with glucose as substrate. During desizing glucose is formed as by-product from degradation of starch. Based on reducing environmental pollution researches have studied to reuse glucose that is formed during desizing as a by-product from the starch degradation, with the use of glucose-oxidase to produce in situ $\mathrm{H}_{2} \mathrm{O}_{2}$ for bleaching cotton. Despite all research there are still the following drawbacks to be solved [Opwis et al., 1999, Tzanov et al. 2001, 2002, Eren et al., 2009].

1. the quantity $\mathrm{H}_{2} \mathrm{O}_{2}$ used during bio bleaching is 2-fold compared to conventional bleaching. The extra $\mathrm{H}_{2} \mathrm{O}_{2}$ is necessary because it is believed that a substantial part of the in situ generated peroxide also oxidizes impurities in the bleaching bath;

2. aeration of the bulk is prerequisite for in situ generation of $\mathrm{H}_{2} \mathrm{O}_{2}$. It is known from wastewater treatment that aeration of starch-residues containing wastewater gives a tremendous foam development and strong smell. So it is not possible to implement this process in existing installed base without substantial investment;

3. process time is too long to be industrially acceptable;

4. $\mathrm{H}_{2} \mathrm{O}_{2}$ is in situ generated in acidic environment. Bioscouring with the enzymes cutinase and pectinase shows a promising performance in an alkaline environment. The in situ generation of $\mathrm{H}_{2} \mathrm{O}_{2}$ in acidic environment requires an extra process step.

Based on the drawbacks as they have been mentioned before it has been decided that glucoseoxidase is not selected as an enzyme for in situ generation of $\mathrm{H}_{2} \mathrm{O}_{2}$ during bio-scouring.

\section{Catalase}

Catalases are enzymes that are used after bleaching to catalyze the decomposition of residual $\mathrm{H}_{2} \mathrm{O}_{2}$ and so reduction of rinsing water can be achieved. Catalases belong to the group of the oxidoreductases. The use of catalase is promoted to remove residual $\mathrm{H}_{2} \mathrm{O}_{2}$ before dyeing with oxidation sensitive dyes to avoid color differences. It is expected to realize an environmental 
advantage in discontinuous processes because a rinsing step can be passed. The advantages of catalase in the industry are still under discussion. The main argument for the use of catalase is the decomposition of residual $\mathrm{H}_{2} \mathrm{O}_{2}$ during rinsing. The enzyme catalase is used in cases of low temperature rinsing, where the rinsing step after pre-treatment is followed by the dyeing of the fabric, as a so-called peroxide-killer to avoid pre-oxidation of dyes.

The rinsing temperature in conventional bleaching is about $95^{\circ} \mathrm{C}$, which is above the decomposition temperature of peroxide [Topalovic, 2007]. During drying the residual peroxide is thermally decomposed. It is decided not to select catalase for further experiments in pretreatment of cotton as in continuous pre-treatment of cotton the last process step includes drying.

\section{Xylanase}

Seed coat fragments are dark (black or brown) colored fragments and there are often linters attached to the seed coat. The attached linters are twisted in the yarn resulting in inadequate mechanical removal of the seed coat fragment during ginning. The dark seed coat fragments stand out against the white bleached cotton when it is not sufficiently removed, resulting in rejected quality.

Seed coat fragments hinder broad application of enzyme-based pre-treatment. The performance of the enzyme xylanase has been evaluated for seed coat fragment removal. Csiszár et al. (2006) reported that xylanase pre-treatment of cotton resulted in a significant increase in the reducing sugars, but that lignin-like materials in the bulk are negligible. It is likely that xylanase degrades the carbohydrate part of lignocellulose in seed coat fragments, but the hard seed coat as such is in the best case only partly degraded. Further experiments showed that after xylanase treatment acceleration in consecutive alkaline scouring has been observed [Csiszar et al. 2006]. Despite this improvement the alkaline scouring is still necessary and the advantage of xylanase treatment is the reduction of the $\mathrm{NaOH}$ concentration. In literature no reports have been found for the combination of the enzymes xylanase and cellulase as such, or in combination with other bio-scouring enzymes.

The next step in realizing enzymatic treatment is to select a combination of enzymes to achieve one-step enzymatic desizing and scouring at low temperature.

The most attractive way for the industry to implement enzymatic pre-treatment is to develop a process that can be applied easily on an existing installed base. Therefore the aim here, as mentioned in the forgoing sections is to develop one single enzymatic pre-treatment step. Therefore it is necessary to select an enzyme cocktail that delivers the required performance.

\subsection{Enzyme selection for one step processing}

Starting point for the selection of enzymes was the conclusion of Agrawal [Agrawal 2005, Agrawal et al. 2007, 2008] that a combination of cutinase and pectinase perform well together. The objective here was to find an amylase that is compatible with this mixture. 
The following criteria have been used for this selection:

1. surfactant compatibility. Cotton greige fabric is hydrophobic resulting in bad wetting of the fabric and consequently resulting in a poor adsorption of enzymes. Surfactants are needed to overcome this wetting phenomenon;

2. temperature compatibility. The enzymes in the cocktail need to have a high activity in the same temperature range;

3. inhibitory effects. The enzymes selected may not show mutual inhibitory effects to one of the other chemicals in the mixture;

4. the selected enzymes have to perform all in the same $\mathrm{pH}$ range.

Successful enzymatic pre-treatment, on small scale, is reported by using pectinase for destabilizing the primary wall in the scouring step in industry [Anis and Eren, 2002, Bach et al., 1993]. In this process high rinsing temperatures $\left(95^{\circ} \mathrm{C}\right)$ are used. It is assumed that wax is emulsified above its melting temperature of $65-70^{\circ} \mathrm{C}$ [Rouette (Ed.), 2003] and thus reducing the hydrophobic character of cotton when rinsed at the boil. The enzymatic treatment with pectinase is not widely accepted until now. High temperature for rinsing is the major draw back. Despite this reluctance caused by high rinsing temperature, the pectinase-treatment is sometimes industrially implemented to improve the handle of the fabric. The handle of the fabric is softer and less damage of cotton is realized compared to conventional pretreatment. It is believed that this is caused by the reduced concentration of $\mathrm{NaOH}$ and decreased temperature, resulting in a more smooth fibre surface [Agrawal, 2005].

The next challenge is to select an $\alpha$-amylase that fits the operating window for pectinase and cutinase. The following enzymes are candidates for one-bath application at $\mathrm{pH} 8$ and $30^{\circ} \mathrm{C}$ with pectinase and cutinase as reported by Agrawal:

1. Tanazym LTC 01;

2. Baylase RL 986;

3. Baylase RL 987.

All products are obtained from TanatexChemicals.

Tanazym LTC 01 is a commercially available desizing agent. The optimum temperature for this desizing agent is $\mathrm{pH}$ dependant. At $\mathrm{pH} 4$ the maximum enzyme activity is achieved at $60^{\circ} \mathrm{C}$, while at $\mathrm{pH} 7$ the maximum enzyme activity is reported at $80^{\circ} \mathrm{C}$. Baylase $\mathrm{RL} 986$ has its optimum at $\mathrm{pH} 9$ and from $70^{\circ} \mathrm{C}$ sufficient desizing takes place up to $95^{\circ} \mathrm{C}$ for maximum starch removal. Baylase RL 987 shows at $\mathrm{pH} 5$ - 9 an increasing enzyme activity at raising temperature up to $90^{\circ} \mathrm{C}$. The desizing agents Baylase RL 986 and RL 987 are not yet commercially available. The performance of the desizing process depends strongly on the fabric, the reaction temperature, the $\mathrm{pH}$ and the type of starch that has been used. Also the installed base influences the enzymatic performance. Here the impregnating and rinsing compartments influence the performance of the treatment, as here the mass transfer of enzymes and products has to be realized. In combined singeing and impregnating for desizing it has to be noted that singeing dust is formed during the burning-off of the protruding cotton fibres. Industrial experiments show 
that singeing-dust has an acidic buffering effect to the impregnation bath after singeing. It is believed that this is caused by $\mathrm{CO}_{2}$, being a combustion gas that is formed during singeing. The combustion gas is partly dissolved in the impregnation bath resulting in a $\mathrm{pH}$ drop. This phenomenon might influence the selection of amylase for application on industrial scale. Tanazym LTC 01 and Baylase RL 987 seem to be good candidates for the combined desizing and scouring process. In combined singeing-desizing and scouring processes it is expected that Tanazym LTC 01 will show better performance. This is due to the acidic buffering capacity of cotton-dust in the impregnation bath. It is believed that in this acidic environment Tanazym LTC 01 will show better performance than Baylase RL 987 . Baylase RL 986 is not selected due to optimum temperature and $\mathrm{pH}$.

The enzyme cutinase that has been used by Agrawal is only available in small quantities as an experimental product. In this work Cutinase NS 29141 that has been supplied by Tanatex/the Netherlands has been used.

\subsection{Evaluation techniques}

The aim of enzymatic desizing and scouring is sufficient removal of starch, cotton wax and pectin from the fabric. The performance of the treatment is determined by using the following techniques:

- TEGEWA-violet scale test to evaluate the desizing performance;

- wettability test, to evaluate the hydrophilic properties of the fabric;

- residual pectin measurement to evaluate the pectin removal of the fabric.

\section{TEGEWA-violet scale}

This test is developed by the German TEGEWA-institute ('Verband der TextillhilfsmittelLederhilfsmittel-, Gerbstoff- und Waschrohstoff-Industrie e. V.') and is performed to evaluate the rate of desizing. After treatment of the fabric it is stained with a drop of iodine solution. The iodine solution consists of $1 \%$ potassium iodine and $20 \%$ ethanol. Ethanol is added for improved penetration of the solution in the fabric. The fabric can be evaluated after the iodine drop is absorbed. For evaluation the TEGEWA-violet scale is used. On the scale are nine coloured squares. The first square is coloured deep violet and gradually the colours become lighter and the colour becomes more yellowish/brown. The squares are numbered from 1 , the violet square, to 9 the yellowish/brown square. For evaluation the colour of the stain is compared with the colour of the TEGEWA-violet scale and thus the desizing performance is rated [Mueller, 1997]. The Tegewa-violet scale test method is a non-destructive test and can be simply performed by the operator. This test method is fast, easily performed immediately after the production in the bleaching department and is sufficiently accurate for the industry.

\section{Wettability test}

To measure the hydrophilic properties (wetting) of the fabric there are three well-known test methods available. These methods are auto-porosimetry, the capillary rise test and the water drop test. The aim of these tests is to rank the pre-treatment performance in terms of hydrophilicity and thus ranking the capacity for water pick-up. 
Auto-porosimetry is the most accurate test and is used for detailed contact angle determination. The principle of auto-porosimetry is based on the pick-up of different liquids with known surface tension into and out of a porous structure [Miller, 1994].

The structural contact angle in the fabric can be calculated from two plots of the liquid uptake as a function of the effective radius. The first measurement is done with the test liquid (distilled water). The second measurement is done with a reference liquid containing a wetting agent (e.g. Tanaterge Advance)). It is assumed that $(\cos \theta)_{\text {ref }}$ is 1 for the reference liquid and that the test liquid does not form a $0^{\circ}$ contact angle. Knowing the surface tension $\gamma$ from the test and the reference liquid $(\cos \theta)_{\text {test }}$ can be calculated using the following equation [Miller, 1994].

$$
(\cos \theta)_{\text {test }}=\frac{2 \gamma_{\text {ref }}}{(\Delta P)_{r e f}}=\frac{2 \gamma_{\text {test }}}{(\Delta P)_{\text {test }}}
$$

where $\gamma$ is the surface tension in $\mathrm{mN} / \mathrm{m}$ and $\Delta \mathrm{P}$ is the Laplace pressure difference across the liquid/air meniscus $\left(\mathrm{N} / \mathrm{m}^{2}\right)$.

The advantage of this test method is the accuracy while the test results are not affected by changes in the fabric structure due to pre-treatment processes. Despite the accuracy of this method it is not commonly used in industry. Major drawbacks are the time that is needed for one test and the fact that the test cannot be done immediately after production process and in the production department by the operator. So this method will not be used in this work.

The capillary rise test method is also known as the wicking test. The wicking test measures capacity of a fabric to absorb a test liquid. Small strips of fabric are suspended vertically with the lower ends in the test liquid. The liquid rise in the tested sample is measured. The rating is either in time, when rise over a determined distance is tested or the other way around when during a fixed time the capillary rise in $\mathrm{cm}$ is measured. The test is more time consuming than the water drop lifetime test and is it is a destructive method. Therefore the test is not broadly applied although the test is more accurate than the water drop lifetime test. Information of wetting from capillary rise test is mainly important for application techniques where a fast pick up of high concentrated liquor is important. Due to the time-consuming aspect of this test it is not commonly used in industry. Therefore this test method is mot used in this work.

Water drop lifetimetest is a quick method to determine the hydrophilic properties (wetting) of the fabric and is frequently used in industry. Several water drop lifetime test methods have been described. Two well known methods are The TEGEWA drop test [Abel,1987] and the method that has been described in the AATCC test method nr. 79-2000, 'the absorbancy of bleached textiles' [AATCC, 2005]. The AATCC test method is selected for this work as it is commonly used in industry. The test method is based on the absorbance of distilled or deionized water by a fabric over time. For the test the fabric is mounted in an embroidery hoop. A drop of distilled or deionized water is placed on the fabric with a burette. The height of the burette above the fabric is $10 \pm 1 \mathrm{~mm}$. The absorbance time (drop lifetime) is measured with a stopwatch from the moment that the water drop is placed on the fabric until the water drop is absorbed by the fabric. The absorbance point is determined by placing the fabric between the observer and a spot light 
at such an angle that the specular reflectance of the surface of the flattened drop can be seen. The stopwatch is stopped when the fabric gradually absorbed the drop and the wet spot is dull. The test liquid is -for industrial tests- often coloured with Patent Blue $V$ to be able to evaluate the area of the absorbed drop. This gives an indication of absorbance differences between warp and weft yarns in the fabric. The AATCC evaluation technique does not describe the colouring of the test liquid. In this work we use a blank water and therewith follow the description of the AATCC test method. The measured time for the absorbance of the water drop by the fabric is used as indication for hydrophilic properties of the fabric and the wetted area and wettingdirection are only discussed in case of analysis of insufficient hydrophilicity.

In this work the water drop test method according to AATCC Test Method 79-2000 has been used. This test is commonly used in industry in pre-treatment processes and is not time consuming. An extra advantage of this method is that the operator can perform the test after drying of the fabric so that the fabric is tested instantaneously after processing.

\section{Residual pectin measurement}

Pectin is an important constituent in the primary wall of cotton. Pectin renders strength to the cotton fibre and it is hydrophobic. Pectin is partly removed during scouring. After scouring and bleaching the pectin content of the cotton fabric can be measured by dyeing the fabric with Ruthenium-red dye. Also two reference samples are dyed with ruthenium-red dye. The first reference sample (greige fabric) is not scoured and thus no pectin has been removed. The pectin content of this greige fabric is assumed to be $100 \%$ and the second reference sample, which is alkaline scoured at the boil, is set to $0 \%$ residual pectin. The fabric is dyed during 15 minutes at $30^{\circ} \mathrm{C}$ with $0,2 \mathrm{~g} / \mathrm{l}$ Ruthenium Red at an LCR of $1: 10$, followed by a rinse in distilled water at $60^{\circ} \mathrm{C}$. The dyed samples 'before' and 'after' perfect scouring are used to indicate the removal of pectin. The greige dyed sample, which has a dark red colour is the sample that equals $0 \%$ pectin removal. The perfect scoured sample is qualified as $100 \%$ pectin removal. The bio-scoured samples are measured after dyeing and the colour is compared and fitted between $0 \%$ and $100 \%$ pectin removal. After drying the samples has been measured at $540 \mathrm{~nm}$ with the $\mathrm{X}$-Rite Basic Eye $4.5 \mathrm{~mm}$ photospectrometer and the $\mathrm{K} / \mathrm{S}$ values have been calculated. The value $\mathrm{K}$ is the absorption coefficient of the sample and the value $S$ is the measured substrate scattering. The residual pectin content is calculated by the Kubelka Munk equation (Agrawal 2005, Rouette (Ed.) 2003):

residual pectin content in $\%=\frac{\left(\frac{K}{S}-\frac{K}{S_{0}}\right)}{\left(\frac{K}{S_{100}}-\frac{K}{S_{0}}\right)}$

where $\mathrm{K} / \mathrm{S}$ is the measured value of the sample, that is evaluated against $\mathrm{K} / \mathrm{S}_{0}$, the measured value of the greige sample and $K / S_{100}$, the measured value for the scoured sample. The calculated value is an indication of the rate of residual pectin, which depends on the pectin content of the greige fabric and the performance of the scouring process of the benchmark fabric. 


\subsection{Experiments}

The aim of the presented experiments is to select an $\alpha$-amylase that is compatible with the enzymes cutinase and pectinase and auxiliaries in the pre-treatment process. Also the performance of the enzyme cocktail, under various conditions as impregnation and rinsing temperature, $\mathrm{pH}$ and incubation time has been explored. The concentrations of enzymes that are used will not be optimized. The reason for that is that lab-experiments cannot be carried out with a quantity of mechanical energy that is comparable to that in industrial pre-treatment equipment. The mechanical energy from diverse installed base is different due to the construction of the equipment and phenomena as fabric tension, water flow and so on. Further is it almost impossible to find any comparable installed base. Optimization of concentrations is, on an industrial scale, done for specific fabrics, on specific installed base for specific described requirements of the treated fabric. Therefore it is decided not to optimize the enzyme cocktail for specific conditions but to explore the process conditions.

\subsubsection{Materials and method}

\subsubsection{Materials}

Two types of fabrics have been used for the experiments, percalle ex Vlisco and 6060/2020 ex TenCate.

\section{Percale}

Percale is a medium to fine threaded cotton woven fabric in linen weave. The yarns are fine spun with high twist. The weight of the Percale fabric that is used is $130-135 \mathrm{~g} / \mathrm{m}^{2}$ and the fabric is sized with starch. Vlisco B.V., that is located in Helmond in the Netherlands, supplied the percale fabric. Applications of the percale fabric are shirts, blouses, clothes and quilt covers. Percale is generally valued as a high quality fabric.

$6060 / 2020$

The fabric $6060 / 2020$ is named for its construction. The warp and weft count is 60 yarns per inch and the yarn number is Ne 20 for warp and weft. Both warp and weft are $100 \%$ cotton. The fabric has a linen woven construction. The weight of the fabric is $150-155 \mathrm{~g} / \mathrm{m}^{2}$ and the size that is used is starch. The fabric is supplied by TenCate Advanced Textiles, which is a subsidiary of Royal TenCate in Almelo in the Netherlands. Applications for 6060/2020 are clothes, interior textiles and covers for garden chairs as well as bed linen. This fabric is a typical high volume product with a corresponding price setting.

A major differentiation between the two fabrics is the twist in the yarns. The percale fabric consists of yarns with higher twist, than 6060/2020. For lab-experiments the use of the less twisted $6060 / 2020$ is preferred as it is easier to process without mechanical energy than a percale fabric. To perform experiments where mechanical energy is applied a percale fabric is preferred as test fabric. The fabric percale and 6060/2020 are selected for experiments because percale is known to be a difficult fabric for pre-treatment processes and 6060/2020 is a fabric that is produced in large volumes. The 6060/2020 fabric has the advantage that most textile 
producers know this fabric very well and this makes it easy to communicate the results of the new process in terms of quality and costs.

The chemicals that are used in the experiments are three $\alpha$-amylases, Tanazym LTC01, Baylase RL 986 and Baylase RL 987, Cutinase NS 29141 and pectinase. The pectinase enzyme that has been used in the experiments is the commercially available Bioprep $3000 \mathrm{~L}$. The selected surfactant was Tanaterge Advance. The enzymes and surfactant have been supplied by Tanatex Chemicals in Ede in the Netherlands.

\subsubsection{Method}

This work aims at the development of a continuous and pad batch pre-treatment process on industrial level. Therefore the continuous process is explored in a beaker-glass, where in a bulk liquid the treatment takes place. In the pad batch process the fabric is impregnated on a labpadder, subsequently incubated and finally followed by a rinse. The process time, LCR (liquid to cloth ratio), temperature for incubation and rinsing and $\mathrm{pH}$ are adjusted where possible to industrially applied values.

\section{Continuous experiments}

Characteristic for industrial continuous processes, as already described in Chapter 1, is the relative short process time and high level of applied mechanical energy. The mechanical energy can only be partly applied by stirring or shaking on lab-scale.

Continuous desizing and bio-scouring experiments were performed in a $0,5 \mathrm{~L}$ beaker with fabric samples of $0,01 \mathrm{~m}^{2}$ treated in a chemical solution during 15 minutes in buffered liquor. Tris- $\mathrm{HCl}$ buffer $(50 \mathrm{mM})$ was used in the $\mathrm{pH}$ range $8-10$. The liquor to cloth ratio was 1:100. During the treatment the beaker is placed in temperature controlled Julaba SW 21 shaken bath at $110 \mathrm{rpm}$. After treatment the samples were rinsed during 15 minutes in hot distilled water, followed by double rinse during 5 minutes each at room temperature in distilled water. The liquor to cloth ratio during rinsing was also 1:100. After treatment the samples were dried for at least 24 hours on acrylic plate at room temperature before evaluation of the samples.

\section{Pad batch experiments}

The aim of these experiments was to explore the variables for industrial pad batch desizing and scouring. Characteristic of this process was the impregnation-incubation-rinsing steps, where the mechanical energy applied was very low and this was partly compensated over time during impregnation and with increased concentration enzymes compared to continuous treatment.

The pad batch experiments consist of impregnation of the fabric with the impregnation liquor. The dimension of the samples for pad batch experiments is $160 \times 20 \mathrm{~cm}$. The impregnation of the fabric has been carried out on a Benz padder, type KLF-HV350. The padder has a controlled squeezing-pressure and fabric velocity. The impregnation time was 2 minutes. This time was realized by impregnating the fabric in a beaker glass before it was squeezed on the padder. The impregnation time of 2 minutes was about four times more than on industrial scale treatment. The extra time was chosen to compensate the missing mechanical energy. The pressure is regulated to realize a wet pickup of $90 \%$ o.w.f. (of weight fabric). This pickup was realized with a 
pressure on the squeezing rollers of $1 \mathrm{kPa} / \mathrm{cm}$. The fabric velocity during squeezing on the padder was $6 \mathrm{~m} /$ minute. After padding the fabric was sealed in plastic bag to avoid drying and it was incubated in a climate chamber at a preset temperature. The impregnation and incubation temperature were equal. The fabric was rinsed during 15 minutes in a temperature controlled distilled water-bath after incubation, followed by two rinses in distilled water at RT for 5 minutes. After rinsing the fabric was dried on a clothesline. After drying overnight the samples were evaluated.

\begin{tabular}{|l|l|l|l|}
\hline Product & Description & [c] pad batch & [c] continuous \\
\hline Baylase RL 987 & $\propto$-amylase & $4,0 \mathrm{ml} / \mathrm{l}$ & $15 \mathrm{~g} / \mathrm{l}$ \\
\hline Cutinase NS 29141 & cutinase & $4,0 \mathrm{ml} / \mathrm{l}$ & $15 \mathrm{~g} / \mathrm{l}$ \\
\hline Bioprep 3000 L & pectinase & $1,3 \mathrm{ml} / \mathrm{l}$ & $5 \mathrm{~g} / \mathrm{l}$ \\
\hline Tanaterge Advance & surfactant & $1,0 \mathrm{ml} / \mathrm{l}$ & $20 \mathrm{~g} / \mathrm{l}$ \\
\hline
\end{tabular}

Table 3.1: Concentrations of enzymes and surfactant for desizing and scouring process

The concentration of the enzymes cutinase and pectinase that have been used here was the same as the concentrations that have been used by Agrawal for continuous treatment in a beaker-glass. For pad batch applications higher concentrations of enzymes have been used. This was done because pad batch processing needs long reaction time due to slow mass transfer. The high concentration of enzymes has been used to compensate the slow mass transfer in this process compared to the much faster continuous pre-treatment process.

\subsubsection{Amylase selection}

Three different $\alpha$-amylases are tested, Baylase RL 986 and RL 987 and Tanazym LTC 01. The enzymes have been evaluated for their performance with different temperatures.

The amylases were separately tested in a continuous process as described in the previous section. The test-sample have been referred to as percale. The fabric has been tested according the description of continuous experiments. The experiment was carried out in an aqueous solution that was buffered at $\mathrm{pH}$ 8. The concentrations of enzymes and auxiliaries were respective $15 \mathrm{~g} / \mathrm{l}$ amylase and $20 \mathrm{~g} / \mathrm{l}$ Tanaterge Advance. After incubation the samples were rinsed in hot and cold water and dried.

To explore the compatibility of the selected amylase it was tested with the other desizing and scouring products. For the test $15 \mathrm{~g} / \mathrm{l}$ amylase has been used and the normal concentration of the other products were doubled compared to the advised quantities. The incubation time was 15 minutes, $\mathrm{pH}$ was set at $\mathrm{pH} 7.5$ and the incubation and hot rinse temperature was $35^{\circ} \mathrm{C}$. The experiments were carried out as described in section 3.6.1.2.

\subsubsection{Exploration of the enzyme cocktail in pad-batch and continuous treatment}

The aim of these experiments was to explore the process variables for pad-batch and continuous desizing and scouring with the enzyme cocktail. The studied desizing and scouring process variables, with the enzyme cocktail as basis, were impregnation temperature, rinsing temperature, $\mathrm{pH}$ and incubation time. The concentrations of the enzymes and surfactant that were used in the cocktail are listed in table 3.1. The chemical bath was buffered with $50 \mathrm{mM}$ Tris- $\mathrm{HCl}$ buffer at the required $\mathrm{pH}$. The incubation time for pad-batch treatment was 24 hours 
and for continuous treatment 15 minutes incubation time was used. The fabric that has been treated in these experiments was percale.

\subsection{Results}

\subsubsection{Amylase selection}

Three different $\alpha$-amylases, supplied by Tanatex, have been tested: Baylase RL 986 and RL 987 and Tanazym LTC 01. The percale fabrics have been equally treated with the same concentrations of amylase. The performance of the enzymatic treatment was evaluated for different incubation temperatures. The desizing performance has been evaluated according the TEGEWA violet-scale method as described in section 3.5

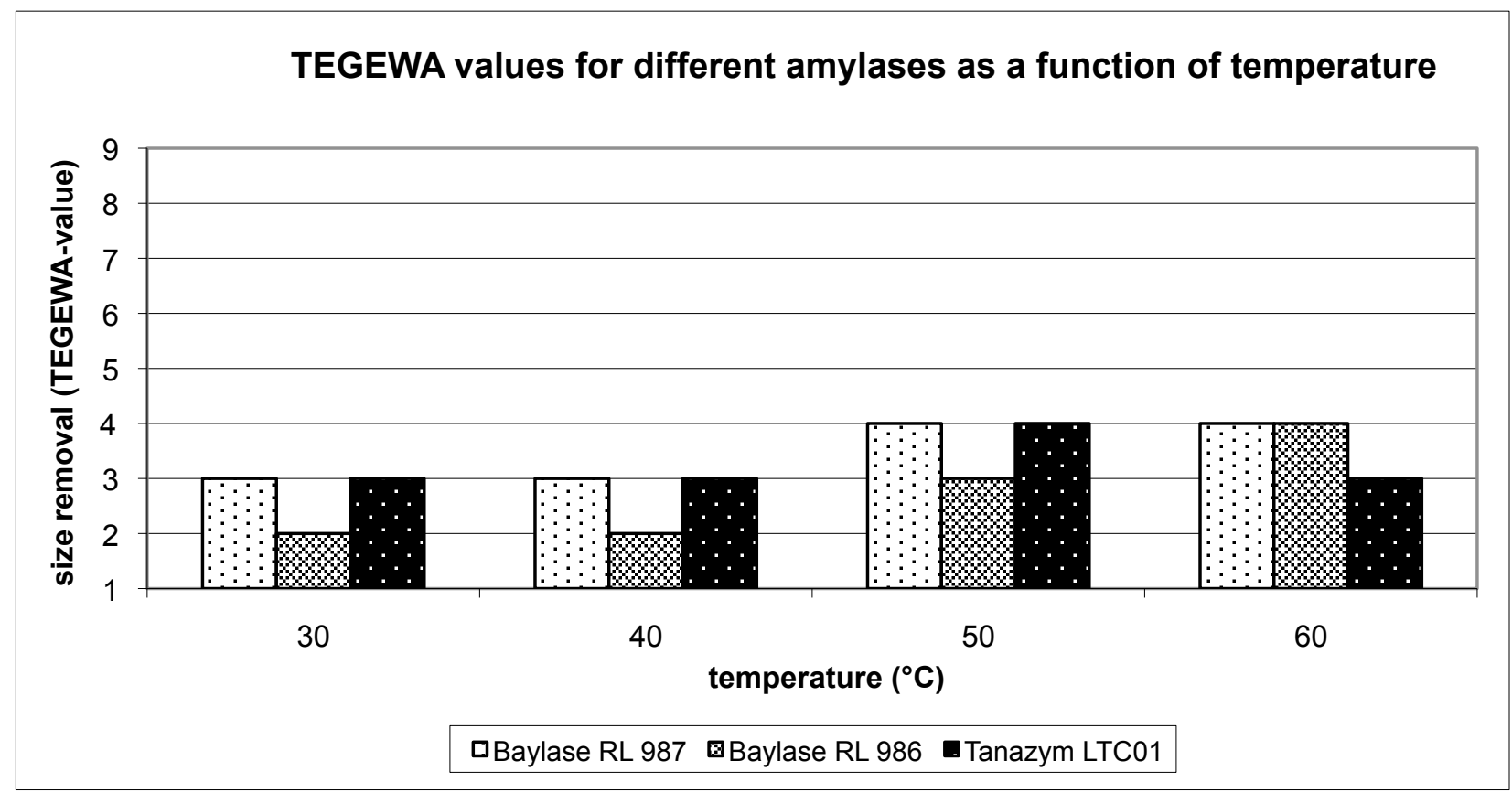

Figure 3.6: Evaluation of the desizing performance of the selected amylases at different temperature

Figure 3.6 shows the desizing performance of the three enzymes, Baylase RL 987, Baylase RL 986 and Tanazym LTC 10. Baylase RL 986 showed in the temperature range of $60^{\circ} \mathrm{C}$ a comparable result as Baylase RL 987 and at lower temperatures Baylase RL986 and Tanazym LTC 01 showed better performance. Therefore Baylase RL 986 was not selected as a candidate for the enzyme cocktail. In the other temperature ranges Baylase RL 987 and Tanazym LTC 01 were comparable except for the performance at $60^{\circ} \mathrm{C}$.

\subsubsection{Compatibility of Baylase RL 987 with other desizing and scouring agents}

The enzyme Baylase RL 987 was selected for the enzyme cocktail. Therefore it was necessary to determine the compatibility of the a-amylase Baylase RL 987 with the other desizing and scouring agents. For the compatibility test the normal concentration Baylase RL 987 and the double concentration of the other pre-treatment agents has been used. All agents were tested 
separately with Baylase RL 987 . The selected treatment method was continuous treatment. After treatment of the fabric the desizing performance of Baylase RL 987 was evaluated according the TEGEWA violet-scale method. Here it was assumed that poor desizing is directly related to inhibitory effects caused by the added agent to Baylase RL 987 liquor.

The fabric that has been used in this experiment is 6060/2020. The fabric i6060/2020 has a more open construction and less twisted yarns. Therefore it was expected that the desizing performance will be better on this fabric than on percale. The results are presented in figure 3.7.

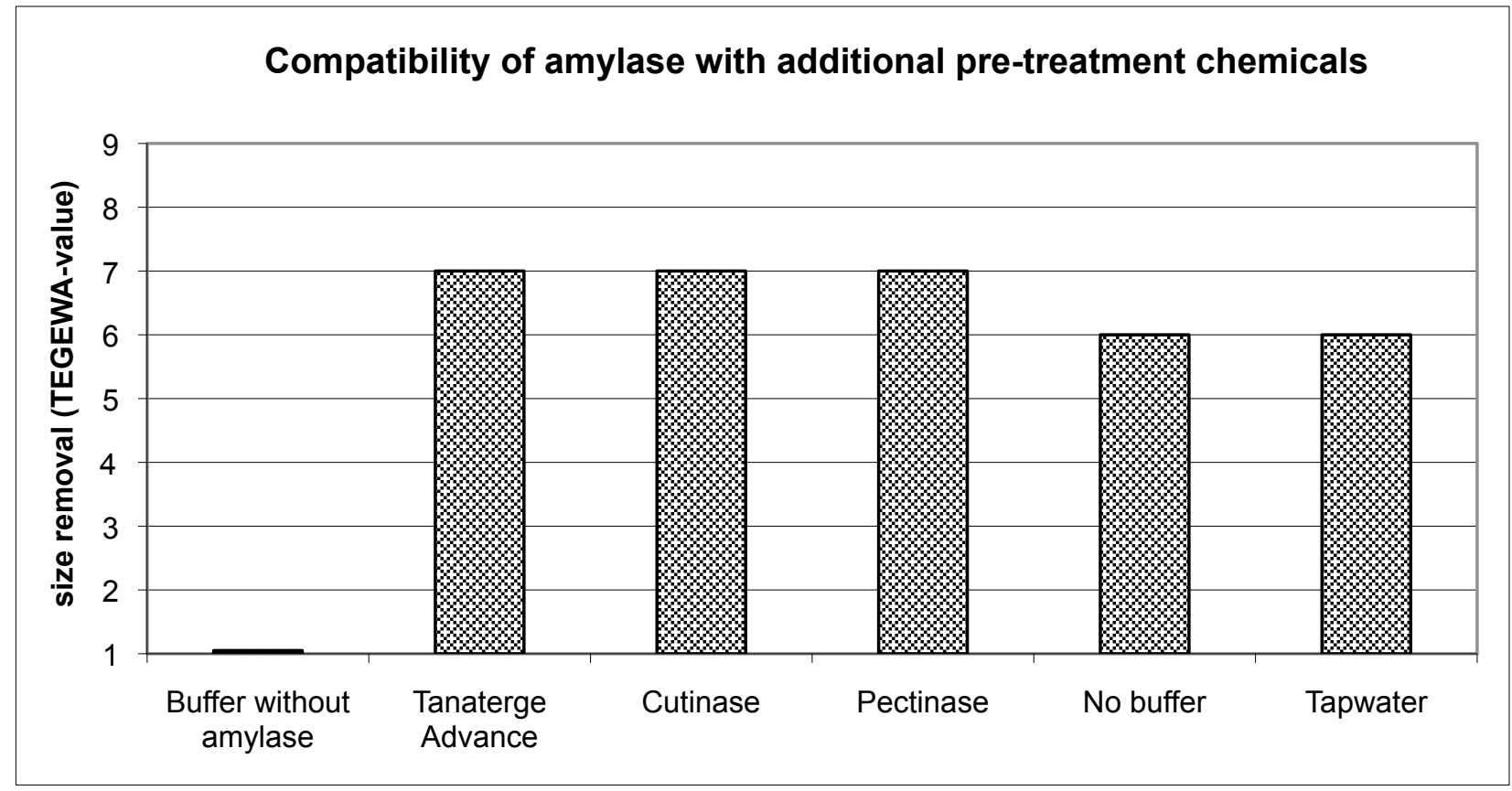

Figure 3.7: TEGEWA-value of compatibility-test of Baylase RL 987 and other pre-treatment agents for the fabric $6060 / 2020$

In that figure the performance of the desizing and scouring agents with Baylase RL 987 has been shown. From the graph it is clear that the other selected enzymes and the surfactant Tanaterge Advance shows no inhibitory effects on Baylase RL 987. So here it can be concluded that Baylase RL 987 is a suitable candidate as desizing enzyme in the enzyme cocktail for combined enzymatic desizing and scouring of cotton.

\subsubsection{Results for desizing and bio-scouring in pad batch processing}

To incorporate bio-scouring in industrial pre-treatment of cotton it was necessary to explore the influence of the process variables and to find the performance determining conditions. The explored variables were:

- impregnation and rinsing temperature;

- $\mathrm{pH}$;

- incubation time. 
For these experiments the fabric percale has been used. The concentration and chemicals that were used correspond with table 3.1.

The Influence of the impregnation and rinsing temperature on the enzymatic performance In figure 3.8 the desizing performance of the treatment has been shown as a function of the impregnation temperature and rinsing temperatures of 30,40 and $50^{\circ} \mathrm{C}$. The samples were first impregnated at a temperature of $30,40,50$ or $60^{\circ} \mathrm{C}$. Per impregnation temperature three samples have been produced. These three samples were rinsed at different temperatures after incubation. The rinsing temperatures were 30,40 and $50^{\circ} \mathrm{C}$. The samples that have been impregnated at 40,50 and $60^{\circ} \mathrm{C}$ are all treated according the same procedure to evaluate the effect of impregnation and rinsing temperature.

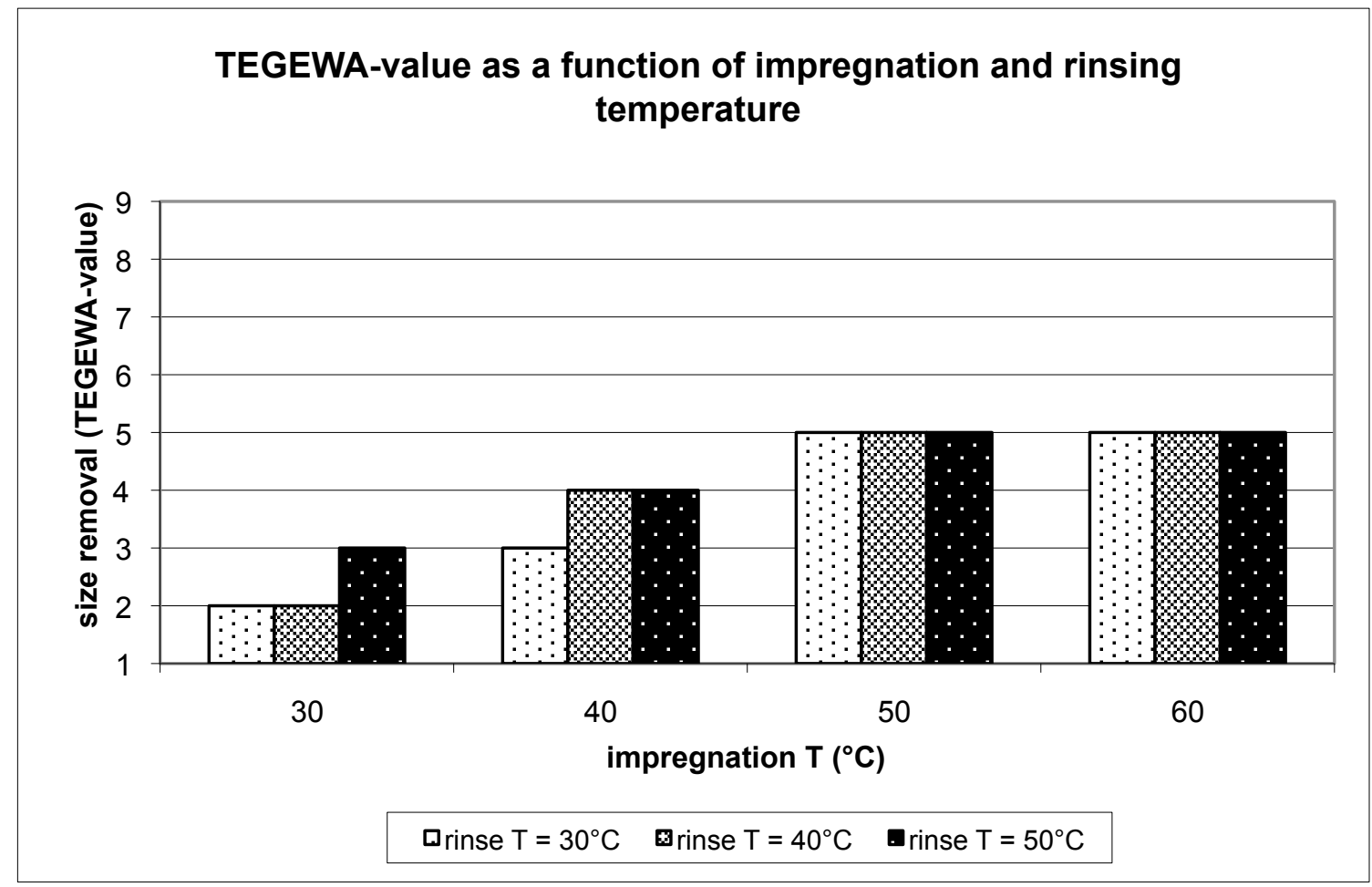

Figure 3.8: Desizing performance as a function of impregnation and rinsing temperature

The experiments showed that the desizing performance was not at the industrial required value of 6 or better. The concentrations enzymes have not been optimized as described previously. It is expected that optimization of the concentration enzymes and the applied mechanical energy will improve the desizing performance due to better penetration of the enzymes in the fabric. It is also known that oxidative treatment, as it is applied during bleaching, will improve the desizing performance. Therefore no optimization of the concentrations has been done. Rather remarkable was the noticed independency of the rinsing temperature. Here it has been concluded that rinsing at a lower temperature than the impregnation temperature is possible. So the impregnation temperature here is the dominant element in pad-batch treatment for the desizing performance. 
In figure 3.9 the impregnation- and rinsing temperature have been evaluated for the scouring performance of the treatment.

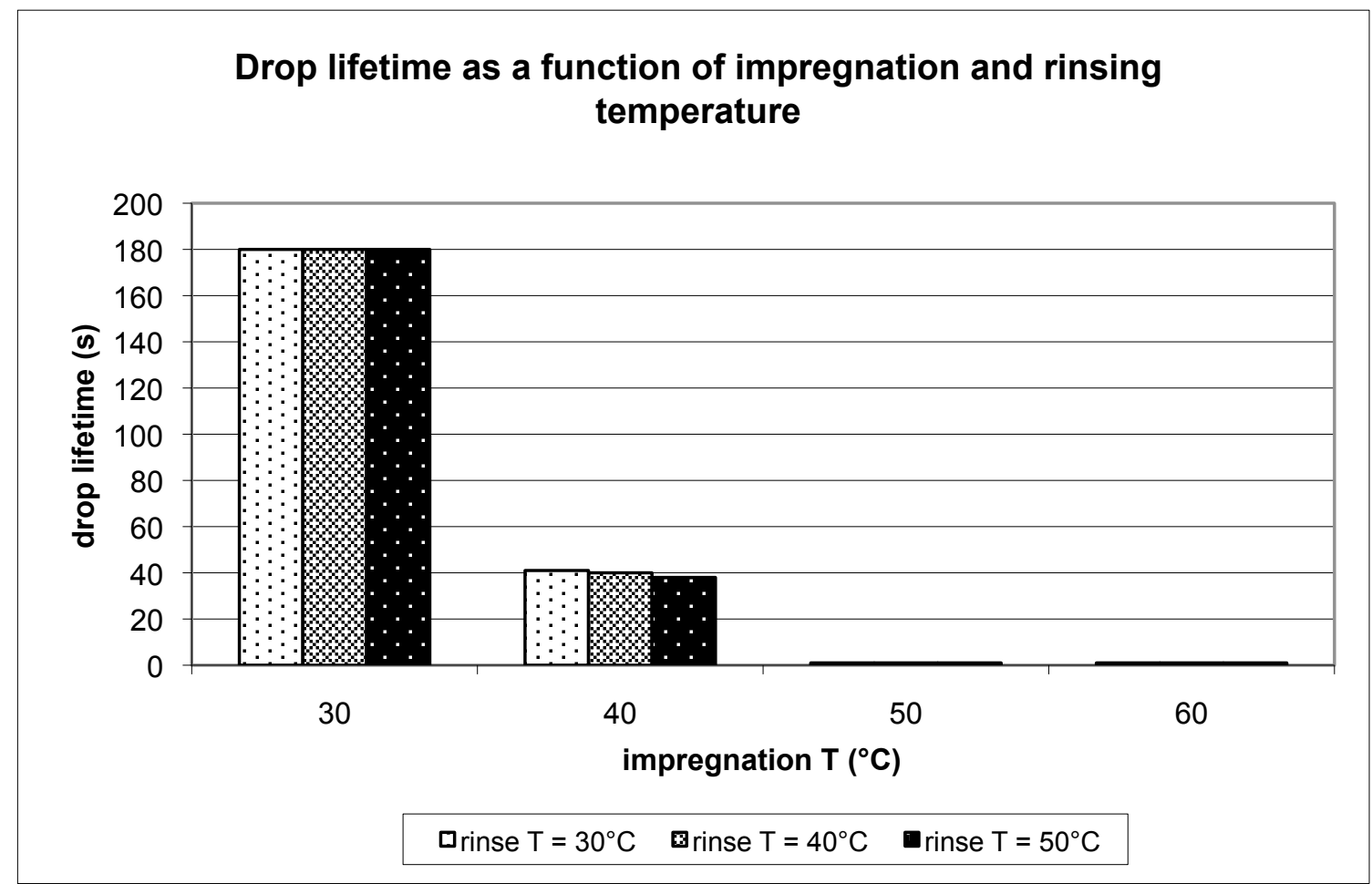

Figure 3.9: Water-drop absorbency performance as a function of process temperature

From the graph it is clear that the impregnation and incubation temperature is decisive for the absorbency of the fabric. A drop lifetime of $3 \mathrm{~s}$ or less is generally qualified as hydrophilic fabric. In the graph it can be seen that this qualification has been realized at an impregnation and incubation temperature above $40^{\circ} \mathrm{C}$. Rather surprising was the influence of the rinsing temperature on the drop lifetime. Here it showed that the rinsing temperature was of minor importance than the impregnation and incubation temperature. So this confirmed the conclusion from the previous section that the impregnation temperature is the key element in this pad batch treatment.

The influence of the $\mathrm{pH}$ on the performance of the enzyme cocktail

Experiments on $\mathrm{pH}$ variation, between $\mathrm{pH} 7$ and $\mathrm{pH} 9$, at an impregnation temperature and rinsing temperature of $50^{\circ} \mathrm{C}$ showed no substantial difference for TEGEWA-value for desizing and water drop lifetime-test. The concentrations chemicals that were used for this experiment are shown in table 3.1 and the impregnation liquor was not buffered. This experiment showed, as it is clear from figure 3.10 that the $\mathrm{pH}$ of the bath was not dominant in the tested $\mathrm{pH}$-range, however the desizing performance slightly decreases at $\mathrm{pH}$ 9. It was concluded here that it is likely that the $\mathrm{pH}$-range for industrial processing is adequately robust for the automatic dosing of the chemicals. 


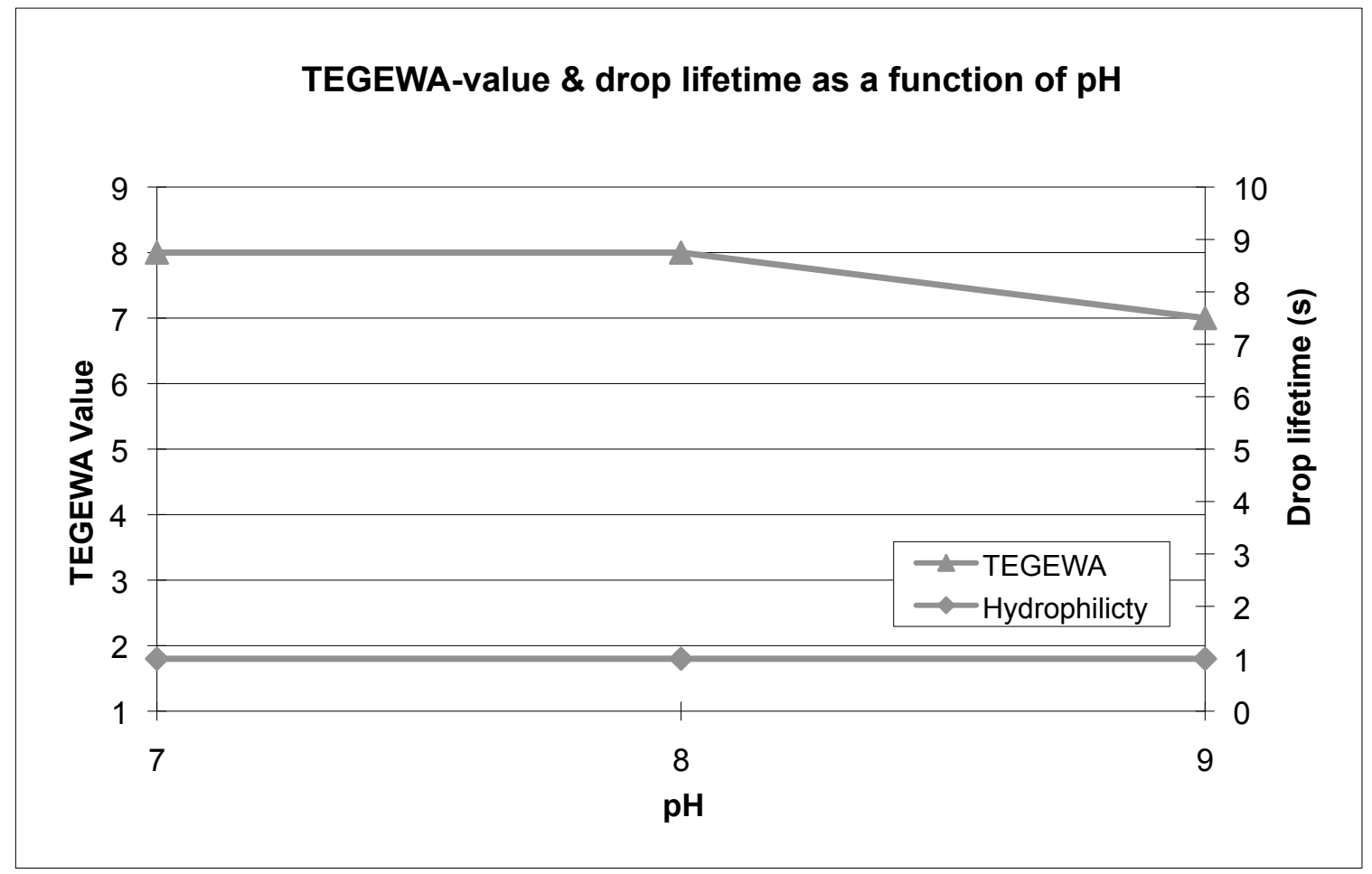

Figure 3.10: TEGEWA-value and drop lifetime as a function of $\mathrm{pH}$

The influence of the incubation time on the performance of the enzyme cocktail

The relation between the incubation time and performance of the enzyme cocktail was evaluated for the performance indicators TEGEWA-violet scale and water-drop lifetime. The results are shown in figure 3.11. In this experiment the concentration of the chemicals has been according table 3.1 and the impregnation and rinsing temperature was $50^{\circ} \mathrm{C}$. The liquor was buffered at $\mathrm{pH}$ 8 with $50 \mathrm{mM}$ Tris-HCl buffer.

Figure 3.11 makes clear that after an incubation time of 24 hours in this experiment the maximum TEGEWA-value 5 is realized. The drop lifetime was $1 \mathrm{~s}$ after 24 hours. 


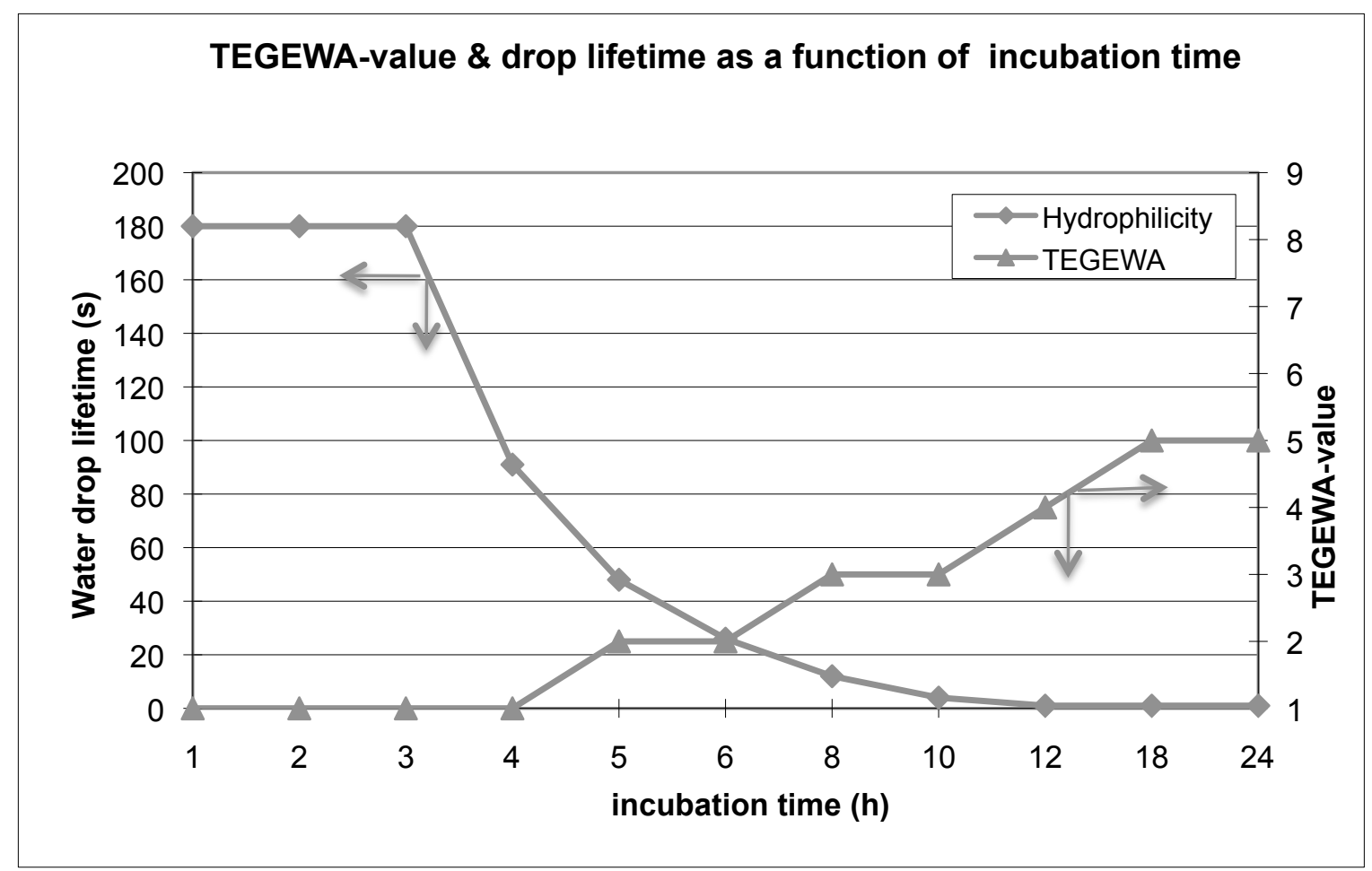

Figure 3.11: Performance of the enzyme cocktail at varied incubation time

So the chosen 24 hours standard incubation time is sufficient for one-bath desizing and bioscouring in terms of drop lifetime. The desizing performance however is rather poor, when compared with the industrial standard of the Tegewa-violet scale value 5.

\subsubsection{Results for desizing and bio-scouring in continuous processing}

Continuous processing on lab-scale level consists of a treatment of the fabric in a beaker. After the treatment the fabric is rinsed several times in warm and cold water. The chemicals and concentrations used are according to 'column continuous' in table 3.1. The experiments have been varied on the following aspects:

- reaction bath temperature;

- $\mathrm{pH}$.

The performance indicators for desizing and bio-scouring are the TEGEWA-value, the water drop lifetime and the residual pectin content.

\section{Reaction temperature}

The temperature of the reaction bath was varied from 30 to $60^{\circ} \mathrm{C}$ at $\mathrm{pH} 8$. The performance of the enzyme cocktail was better at increasing reaction temperature (table 3.2 ) for all performance indicators. 


\begin{tabular}{|c|c|c|c|}
\hline $\begin{array}{l}\text { Temperature } \\
\text { in }{ }^{\circ} \mathbf{C}\end{array}$ & TEGEWA-value & $\begin{array}{l}\text { Water-drop lifetime } \\
\text { in s }\end{array}$ & $\begin{array}{l}\text { Residual pectin } \\
\text { in \% }\end{array}$ \\
\hline 30 & 1 & $>180$ & 68 \\
\hline 40 & 3 & 18 & 55 \\
\hline 45 & 5 & 10 & 47 \\
\hline 50 & 6 & 3 & 42 \\
\hline 55 & 6 & 3 & 39 \\
\hline 60 & 6 & 3 & 35 \\
\hline
\end{tabular}

Table 3.2: Influence of reaction temperature on the performance of the enzyme-cocktail

So at a temperature of $50^{\circ} \mathrm{C}$ and higher the performance indicators already meet the minimum industrial requirements, although the bleaching step, which normally improves the desizing and hydrophilicity, has not been performed.

\section{$\mathrm{pH}$ variation}

To study the effect of $\mathrm{pH}$ the system performance has been measured at different $\mathrm{pH}$ values from 6 until 9. The reaction temperature was $50^{\circ} \mathrm{C}$ and the reaction time was 15 minutes. The samples have been dried on an acrylic plate after two warm rinses at $50^{\circ} \mathrm{C}$ and one rinse at room temperature. The results are shown in table 3.3.

\begin{tabular}{|c|c|c|c|}
\hline pH & TEGEWA-value & $\begin{array}{l}\text { Water-drop lifetime } \\
\text { in s }\end{array}$ & $\begin{array}{l}\text { Residual pectin } \\
\text { in \% }\end{array}$ \\
\hline 6 & 3 & 15 & 56 \\
\hline 7 & 5 & 8 & 52 \\
\hline 7,5 & 5 & 5 & 50 \\
\hline 8 & 6 & 3 & 42 \\
\hline 8,5 & 6 & 4 & 43 \\
\hline 9 & 5 & 9 & 56 \\
\hline
\end{tabular}

Table 3.3: Influence of the $\mathrm{pH}$ on the performance of the enzyme cocktail

From the results it has been concluded that the optimum $\mathrm{pH}$ for the enzyme cocktail is $\mathrm{pH}$. The performance will be improved by consecutive bleaching and therefore it is likely that the $\mathrm{pH}$ is within industrial applied ranges.

\subsubsection{Conclusion and discussion}

A single desizing and scouring step has been developed by the composition of an enzyme cocktail. The mixture consists of amylase, cutinase, pectinase and surfactant as it has been described previously. The performance of the enzyme cocktail has been evaluated for continuous and pad batch pre-treatment processes.

The results of the experiments are summarized below:

- pad-batch experiments showed that the impregnation and incubation temperature are dominating the performance and that the rinsing temperature is of minor influence; 
- the enzyme cocktail shows adequate performance in the explored $\mathrm{pH}$ range from $\mathrm{pH}$ 7-9 in pad batch processes. A slight decrease of desizing however was noticed at $\mathrm{pH} 9$;

- the incubation time of 18 hours for pad batch processes showed a satisfactory wetting performance. After 24 hours the maximum TEGEWA-value of 6 has been realized in these experiments;

- it is likely that continuous processing will show sufficient performance at low temperature and at slight alkaline environment.

The finding that the rinsing temperature, in the evaluated range between 30 and $50^{\circ} \mathrm{C}$, is of minor influence on the performance of the enzyme cocktail gives an opportunity for decreasing the rinsing temperature during industrial processing. The evaluated influence of $\mathrm{pH}$ and incubation time was an indication for sufficient robustness for industrial processing.

It is known that desizing/bio-scouring and subsequent bleaching will improve the performance of the desizing/bio-scouring treatment as it has been described before. It is also expected that increasing the mechanical energy will accelerate and improve the performance, so therefore further optimization of the enzyme cocktail, concentrations and operating window has to be performed during industrial experiments.

\subsection{Seed coat fragment}

\subsubsection{Introduction}

As it has been mentioned in Chapter 2 the cotton fibres grow inside the cotton boll and are attached to the seed coat. Before harvesting this boll opens and the cotton fibres are pushed out. During harvesting the cotton bolls are gathered mechanically. It is important avoid as much as possible to pick-up impurities as leafs and stems during harvesting. After harvesting cotton fibres have to be separated from cottonseed. The process to separate cotton fibres, the socalled lint, and cottonseed is called ginning. During harvesting, but mostly during the ginning process some cottonseed is broken into small fragments. These fragments are the so-called seed-coat fragments (SCF's). The fragments and other impurities are shown in figure 3.12. In this picture so called neps (a) SCF's (b) and unidentified impurities are shown. Neps are hairy entanglements of inferior short cotton fibres. It is not hard to understand that these impurities are harder to remove after yarn production, weaving and knitting, what makes the removal of impurities during ginning important. 

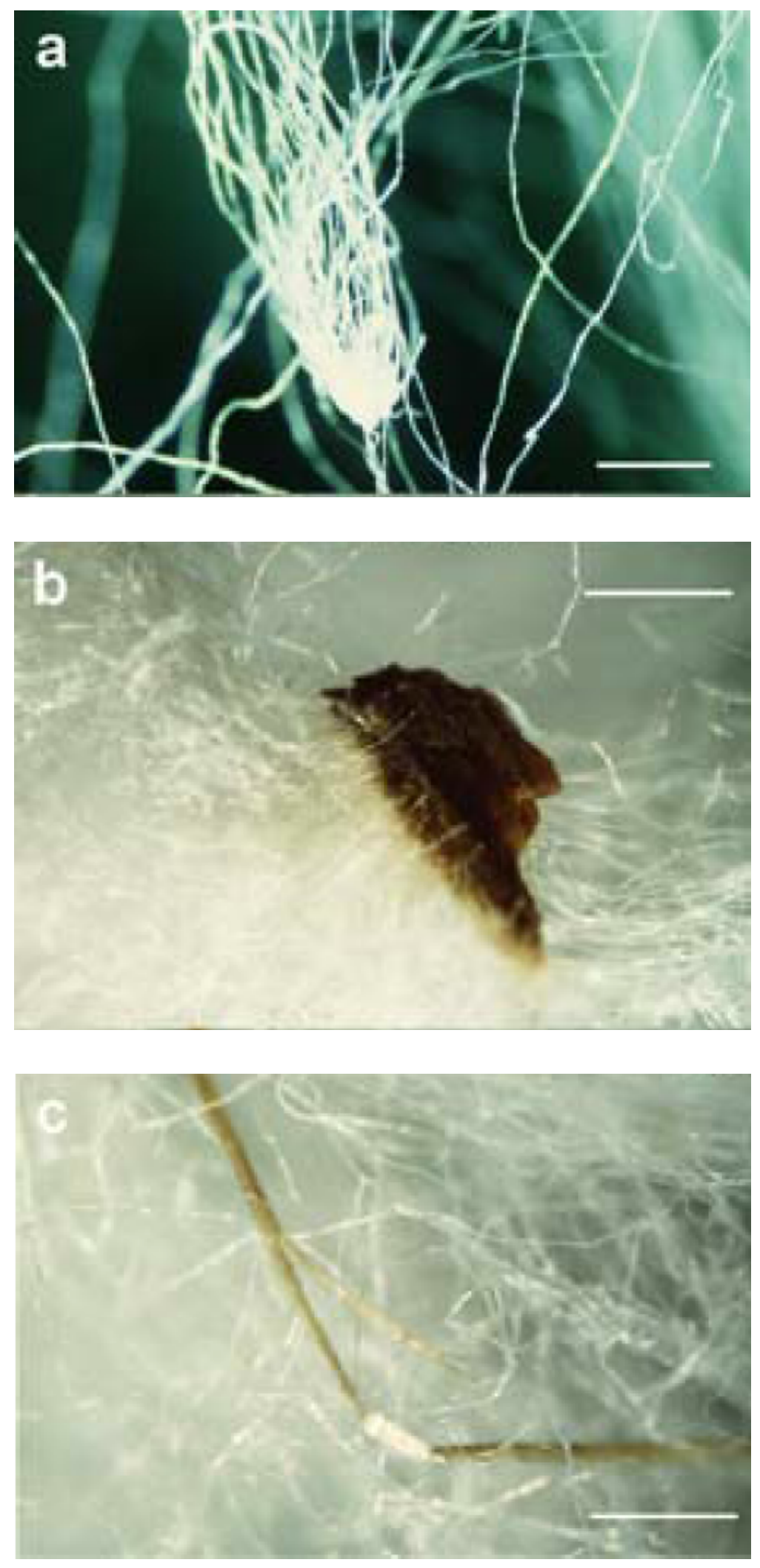

Figure 3.12: Impurities in cotton: (a) fibre entanglement (neps), (b) seedcoat fragment with other fibres attached to it, (c) unidentified non-seed impurity (bar $=0.5 \mathrm{~mm}$ ) 
After spinning and weaving the SCF's are visible in the fabric as small dark or black spots. In the fabric 6060/2020 we have explored the number and size of the fragments. The dimensions of the spots vary from more than $1 \mathrm{~mm}$ length to only a fraction of this length and more than 100 dark spots per $100 \mathrm{~cm}^{2}$ fabric have been counted. A picture of a SCF in the 6060/2020 fabric that has been used in the experiments in this work is shown in figure 3.13.

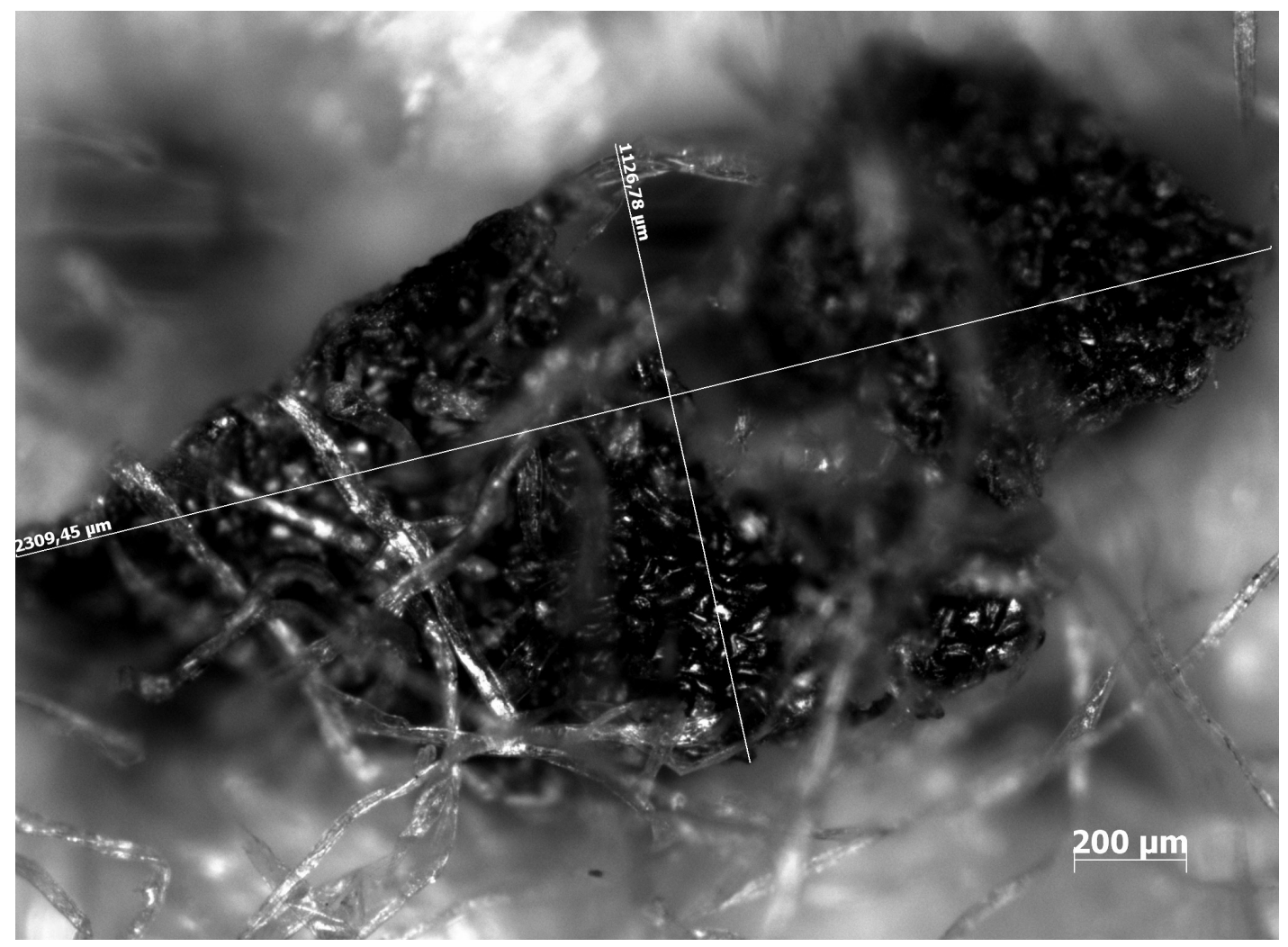

Figure 3.13: Close-up and dimensions of a SCF as it is seen in the fabric 6060/2020

This SCF is rather large and the dimensions are $2300 \times 1100 \mu \mathrm{m}$. It has been reported that very high quantities of seed coat fragments per gram lint with microscopic observation have been found in cotton lint [Jacobson et al., 2001]. The higher quantities of SCF's that have been reported by Jacobsen can be explained because here the cotton lint was studied under microscopic surveillance and on the 6060/2020 fabric only the SCF's have been counted on one side of this fabric. This means that the number of SCF's in the fabric has probably to be doubled at least.

As mentioned in Chapter 2 fragments, which are not separated during ginning, have to be removed during scouring and bleaching. It is likely that during the bleaching-process the fragments are made invisible due to decolourization. Neps that are attached to the seed coats are also present in a fabric. The neps are mainly visible in a fabric when they contain immature cotton and therefore the dye pick-up of the nep is unsatisfactory.

The SCF's can be noticed in a fabric as dark spots. This can be seen as well after bleaching as after dyeing in light and medium colour shades. Only black and marine colours are able to hide the SCF's. So insufficient removal or decolourization of SCF's leads to rejected production. 


\subsubsection{Morphology of seed coat fragments}

To develop a strategy to remove or to decolour SCF's it is necessary to reveal the chemical constitution of SCF's.

Cotton fibres grow out of the outer epidermis. In cotton seed the following anatomic parts are distinguished:

1. outer epidermis;

2. outer pigment layer;

3. colourless layer;

4. upper and lower palisade;

5. inner pigment layer;

6. inner epidermis.

Fourier-transform mid-infrared (FT-IR) mapping and histochemical staining are used to reveal the location and relative importance of chemical components involved with the base of cotton fibres and their associated seed coat [Himmelsbach et al., 2003]. FT-IR mapping is used to identify the chemical components in seed coats by measuring the absorbance band for the distinctive parts. For histochemical staining the following chemicals have been used:

- $\quad$ red Oil O for staining waxes;

- ruthenium Red for staining pectins;

- acid phloroglucinol for staining lignins;

- vanillin- $\mathrm{HCl}$ for staining tannins.

The two complementary techniques were used to identify the nature of the chemical components that hold cotton fibres at their bases and to identify other parts of the SCF that have been found as part of the trash component of ginned cotton.

This know how can be used to develop a strategy to remove linters from cottonseed to enhance the mechanical removal of SCF's. It is found with FT-IR mapping that waxes and long-chain alcohols are present adjacent to the base of cotton fibres on the shank part of their bases, at their point of emerging from and elsewhere in the outer epidermis tissue. Staining the outer epidermis with Ruthenium red shows the presence of carbohydrates within the outer epidermis. Pectate salts and other compounds have been found near the shanks and are believed to be important in anchoring the fibres at their feet in the outer pigment tissue. In the outer pigment layer tannins and pre-tannins have been determined. Therefore not only the presence of pectins and hemicelluloses, but also tannins or a pre-tannin phenolic material must be considered in attempting to arrive at treatments to improve the release of the fibre base from the seed coat. Much of the aromatic species that is present in the colourless layer is lignin. The anatomical components are shown in figure 3.14 representing a schematic drawing of the cross section of cotton seed coat. 


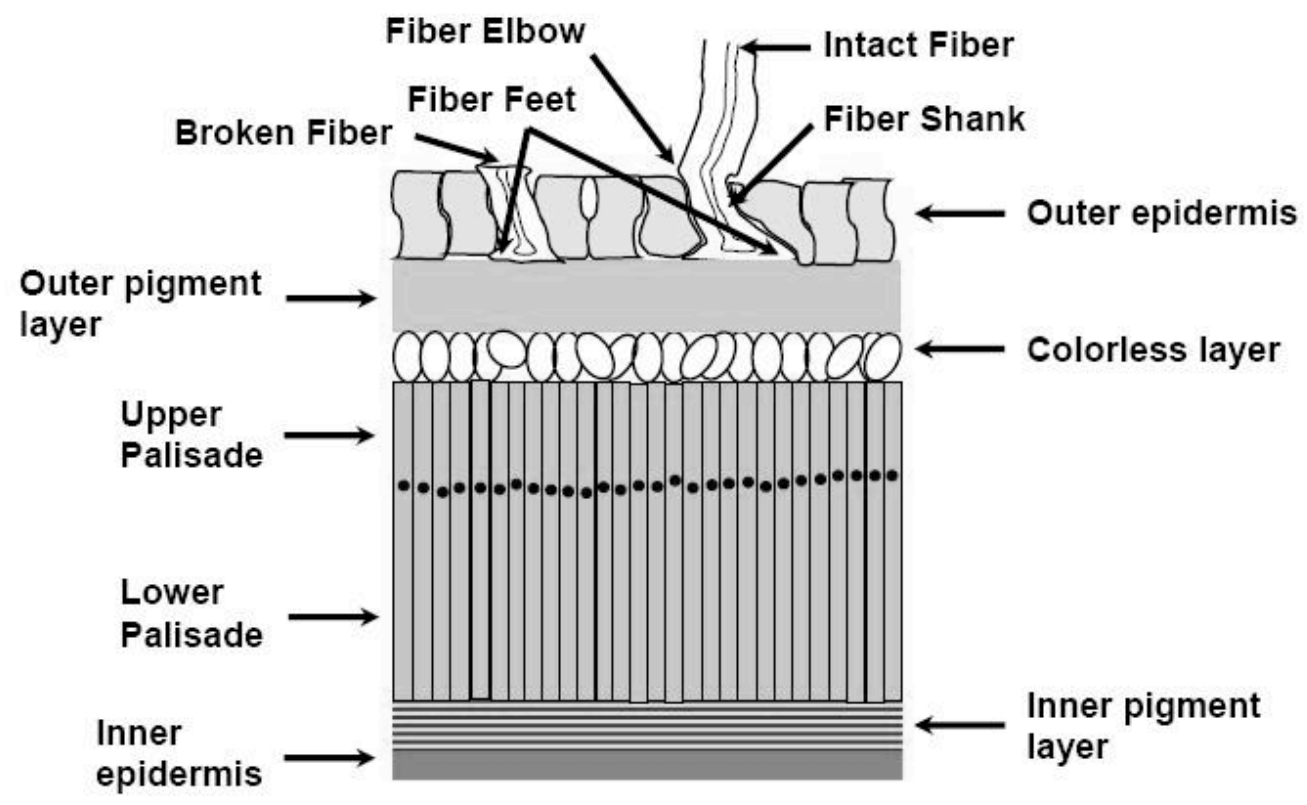

Figure 3.14: A schematic drawing of a cross section of a cotton seed coat showing its anatomical components.[Himmelsbach et al., 2003]

Seed coats contain calcium ions in concentrations up to $35,000 \mathrm{ppm}$ [Losonci et al., 2005]. The cotton fibre also contains calcium ions, but here the concentrations found were in an order of magnitude of $500 \mathrm{ppm}$. In the cotton fibre the egg-box model has been used to explain the strength of the primary wall [Agrawal, 2005]. The positively charged $\mathrm{Ca}^{2+}$ ions form cross-links with non-esterified pectin and thus holding cell wall components together. In seed coats it is possible to form more cross-links due to the high concentration of calcium ions and thus giving the seed coat its strength, resulting in a hard shell.

Quantitative analyses of the chemical constituents of SCF's have been listed in table 3.4. Based on the constituents of SCF's and the morphology of the cotton fibres the following enzymes are selected as candidates for enzymatic SCF degradation:

- cutinase, for wax degradation;

- pectinase for pectin degradation;

- cellulase for removal of the fibres and neps attached to the seed coat fragment;

- xylanase for degradation of the lignin-holocellulose structure.

\begin{tabular}{|l|c|}
\hline Constituents & \% dry weight \\
\hline Wax & $\mathbf{5 . 6}$ \\
\hline Lignin & $\mathbf{2 8 . 3}$ \\
\hline Holocellulose (total) & $\mathbf{4 1 . 3}$ \\
\hline Holocellulose (a-cellulose) & $(13)$ \\
\hline Holocellulose (pentosan) & $(7.2)$ \\
\hline Ash & $\mathbf{1 2 . 8}$ \\
\hline Moisture & $\mathbf{8 . 3}$ \\
\hline Others & $\mathbf{3 . 7}$ \\
\hline
\end{tabular}

Table 3.4: Constituents in SCF [Csiszar, 1987] 
From the table it can be concluded that holocellulose is the main constituent of seed coats and that it accounts for $41 \%$ of the dry weight. Wax and lignin account for respective 6 and $28 \%$ of the dry weight. The relative part of the constituents of SCF's differs in other work from table 3.5. It is believed that this is caused by material from different origin.

\subsubsection{Options for seed coat fragment removal}

The first option is to destabilize or to remove SCF's from a fabric by degradation of the seed coat fragment during bio-scouring so that less harsh chemistry can be used in the consecutive bleaching-step. The second option is to explore the enzymatic removal of the inferior short cotton fibres that are attached to the SCF's. The idea is to remove the neps that attaché the SCF to the yarn. This can be done by the enzyme cellulase, assuming that cellulose is the most important component of neps. The mechanical energy that is consecutively applied to the fabric during processing will 'throw' out the fragment. Based on the morphology and chemical constitution of seed coats and our previous work on wax and pectin degradation in bio-scouring the following candidate enzymes have been selected:

- cutinase for degradation of the waxy cuticle of the seed coat;

- pectinase for destabilization of the pectic substances in the holocellulose;

- xylanase for the destabilization of the xylans in the holocelluse;

- cellulase for the removal of the cotton fibres that are attached to the fragments.

The enzymatic treatment to destabilize or to remove the SCF's will be incorporated in the bioscouring step, assuming that no inhibitory effects will be determined for one of the candidate enzymes. Therefore the experiments will be performed under the same conditions as the desizing/bio-scouring treatment to avoid an extra treatment. The selected enzymes will be tested separately but also in combination with other selected enzymes to evaluate the performance.

In some experiments EDTA (Ethylene Diamine Tetra-acetic Acid) will be used to destabilize the fragments by the removal of $\mathrm{Ca}^{2+}$ ions and thus eliminating the cross-links.

\subsubsection{Evaluation technique for seed coat removal performance}

The enzymatic seed coat treatment will be evaluated on the following aspects:

1. weight loss, as it is expected that degradation or removal of a seed coat will lead to weight loss;

2. reduction of the fibres on the seed coats. This will be evaluated visually;

3. decolorization of the seed coat, which will be evaluated visually as well.

\section{Evaluation of weight loss}

To evaluate the weight loss of the seed coats the material has been conditioned at $20^{\circ} \mathrm{C}$ at $65 \%$ relative humidity in a climate chamber. After conditioning the material has been weighted before processing. The material has been conditioned again after drying. Consecutively the sample has been weighted. The weight loss is calculated as a percentage of the original weight of the sample. 
Evaluation of the reduction of fibres on the seed coat

The removal of the neps from seed coats has been evaluated visually because the weight of the neps in relation to the weight of the fragments is negligible.

\section{Evaluation of decolorization}

Decolorization of the SCF's has been evaluated visually, without the use of colour measurement devices. The treated material consists of individual fragments. These fragments cannot be ordered in a way that colour measurement of a specific area is reproducible. The fragments have a dark colour and the neps that are attached to the fragment have a yellow/brownish colour. The quantity of the attached fibres to the seed coat is very different and the fibres are connected to one side of the fragment. So the colour measurement is the result of coincidental aspects as quantity of the attached fibres and position of the fragments. Therefore the experiments have rated in yes/no terms of visibility of SCF's.

It has been explored to develop an evaluation technique for the presence of seed coat fragments before and after the treatment by scanning the seed coat containing fabric. This attempt to scan and evaluate the performance of the treated fabric for seed coat removal failed. The reason for this was the dimension stability of the fabric. After treatment the fabric has been shrunk and the scanning of the dark spots in the fabric gave no reproducible result. It was noticed that after treatment the light/dark shades in the fabric changed slightly as impurities were removed. Both the shrinkage of the fabric and the colour change caused that the evaluation with the use of scanning technology was not consistent and therefore it has not been used as a performance indicator for SCF removal.

\subsubsection{Experimental}

The strategy for destabilisation of SCF is to select enzymes that either remove the SCF during enzymatic treatment or destabilize the SCF prior to bleaching and finally remove or decolourize the impurities during bleaching-step. In the experiments the enzyme cocktail cutinase and pectinase are used as the basis. The enzyme amylase has not been used in these experiments, because there is no starch on the seed coats. The enzymes xylanase and cellulase have been selected as candidate enzymes for the degradation of SCF's. The enzymes are investigated separately and in combination with other enzymes in an enzyme cocktail. The first step is to test enzyme cocktails on seed coat fragments after they were separated from the cotton bolls during ginning. These experiments have been carried out in a beaker.

The next step is to repeat the experiments on a fabric containing SCF's. The fabrics will be treated in a one-bath process where all the selected enzymes are mixed or in a two-bath process to be able to apply different $\mathrm{pH}$ when this is required. Experiments will be carried out as pad batch and continuous desizing and bio-scouring. After the enzymatic pre-treatment the fabrics will be bleached. 


\subsubsection{Material and methods}

The material used for the experiments is:

- seed coat fragments (pure form, as they have been collected after ginning);

- 6060/2020, $150 \mathrm{~g} / \mathrm{m}^{2}$;

- percale, $120 \mathrm{~g} / \mathrm{m}^{2}$.

The experiments have been carried out in a beaker-glass. The beaker was filled with buffer solution, heated to the reaction temperature after which the enzymes have been added. Consecutively the substrate materials were added. The incubation time was 60 minutes. The LCR was 1:100 and after incubation the SCF's were two times rinsed at the same temperature as the incubation temperature, followed by a cold rinse. For the experiments distilled water was used. After rinsing the SCF's were dried in an oven at $60^{\circ} \mathrm{C}$ for 24 hours, followed by conditioning during 24 hours in a climate chamber at $20^{\circ} \mathrm{C}$ and a relative humidity of $65 \%$.

For benchmarking the SCF's were treated at $95^{\circ} \mathrm{C}$ with $0,4 \mathrm{ml} \mathrm{NaOH} 38^{\circ} \mathrm{Be}$ and $0,2 \mathrm{ml} / \mathrm{l}$ Tanaterge Advance. The LCR was 1:100 and after the treatment the SCF's were rinsed two times. The chemicals concentrations used are listed in table 3.5.

\begin{tabular}{|l|c|}
\hline Product & {$[\mathbf{C}]$} \\
\hline$\propto$-amylase & $0 \mathrm{~g} / \mathrm{l}$ \\
\hline cutinase & $15 \mathrm{~g} / \mathrm{l}$ \\
\hline pectinase & $5 \mathrm{~g} / \mathrm{l}$ \\
\hline acidic pectinase & $15 \mathrm{~g} / \mathrm{l}$ \\
\hline Tanaterge Advance & $10 \mathrm{~g} / \mathrm{l}$ \\
\hline xylanase & $60 \mathrm{~g} / \mathrm{l}$ \\
\hline cellulase & $50 \mathrm{~g} / \mathrm{l}$ \\
\hline
\end{tabular}

Table 3.5: Chemicals used for degradation of SCF's

The concentrations xylanase and cellulase that have been used are relatively high. The reason for this is that with lower concentrations no measurable or visible effect has been noticed. Both xylanase and cellulase have been supplied by TanatexChemicals. The reported minimum activity is respectively $14,000 \mathrm{U} / \mathrm{gr}$ and $3,500 \mathrm{u} / \mathrm{gr}$. The acidic pectinanase has been obtained from the Institute of Environmental Biotechnology, TUG, in Austria.

\section{Pad batch experiments}

Pad batch experiments consists of three step processes. First the greige fabric has been impregnated on a padder with the enzyme cocktail. For impregnation on the padder the fabric was sewed endless in a closed loop. During the impregnation on the padder the fabric was led through a trough and guided over a number of rollers to mimic the mechanical energy of industrial treatment. The impregnation time was 2 minutes. This experiment is done on a lab padder, Benz, type KLF HV-350. In figure 3.15 the scheme of guided fabric on the padder is showed. After impregnation the fabric was sealed in a plastic bag and subsequently the fabric was incubated in a temperature-controlled oven. The incubation time was $18-24$ hours at a temperature of $50^{\circ} \mathrm{C}$. After incubation the fabric is rinsed two times at $50^{\circ} \mathrm{C}$ followed by bleaching. For pad batch bleaching the same procedure has been followed. 


\section{Continuous experiments}

Continuous experiments were performed in a beaker-glass. It was expected that mechanical energy plays an important role in the removal of SCF's. Here also the experiments are carried out on the padder, where the fabric is sewed endless in a closed loop to mimic mechanical energy applied to the fabric. The impregnation time here is 2 minutes, followed by the reaction time, when the fabric passes during $15-20$ minutes the rollers, without passing a trough filled with chemicals. After the impregnation and reaction the fabric was two times rinsed in a beakerglass a $50^{\circ} \mathrm{C}$, followed by a rinse at room temperature.

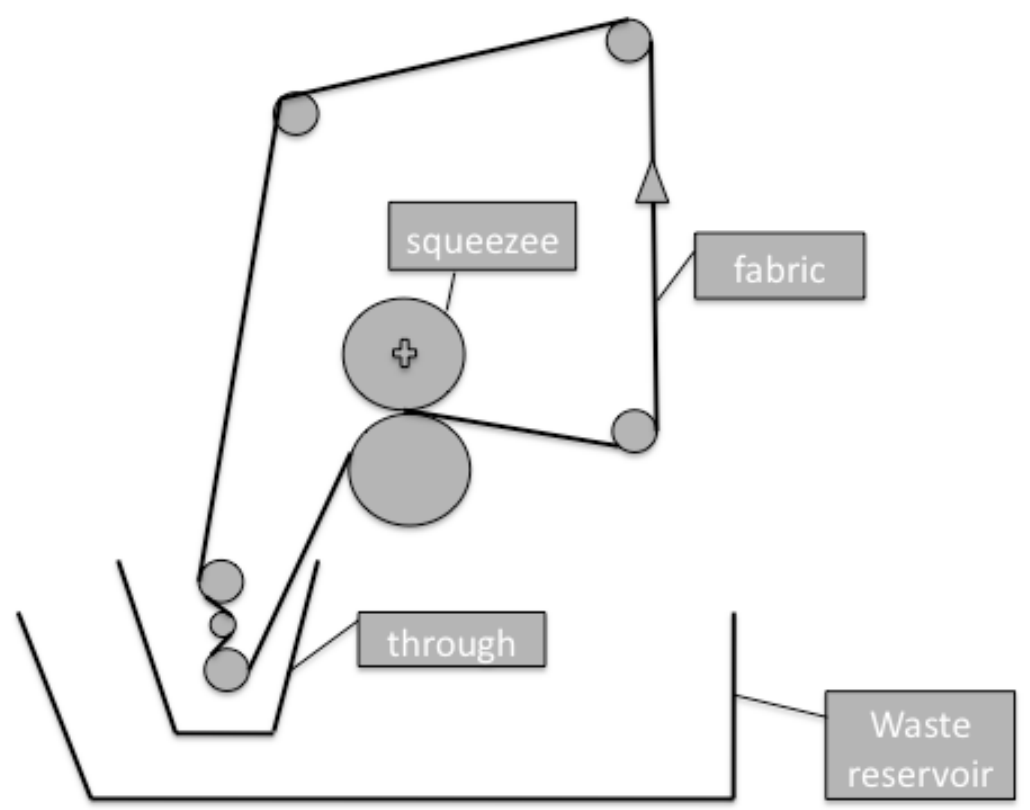

Figure 3.15: Scheme of the Benz padder and fabric guidance during continuous treatment

Only short reaction times gave a reproducible performance. Dehydration of the fabric was noticed after a few minutes. After dehydration no further mass transfer of enzymes or other pretreatment chemicals into the substrate capillaries was possible. There will also be no hydrolytic action of the enzymes due to absence of water. Therefore the results of these experiments were not reproducible on the equipment that has been used. So only the beaker-glass experiments have been reported as continuous experiments.

\subsubsection{Results}

The weight loss of SCF's after treatment with different combinations of enzymes and EDTA has been reported in figure 3.16. All samples were rinsed in distilled water to remove the watersoluble impurities. After this treatment the samples were dried, weighed again and enzymatically treated. After the enzymatic treatment the samples were weighed again and the weight loss was calculated. 
The following experiments have been done:

1. blank treatment to rinse out the water-soluble impurities;

and enzymatic treatments with:

2. cutinase;

3. cutinase and pectinase;

4. xylanase;

5. cutinase and xylanase;

6. pectinase and xylanase;

7. cutinase, pectinase and xylanase;

8. cutinase, xylanase and cellulase;

9. acidic pectinase;

10. acidic pectinase and xylanase;

11. xylanase and EDTA;

12. cutinase, xylanase and EDTA.

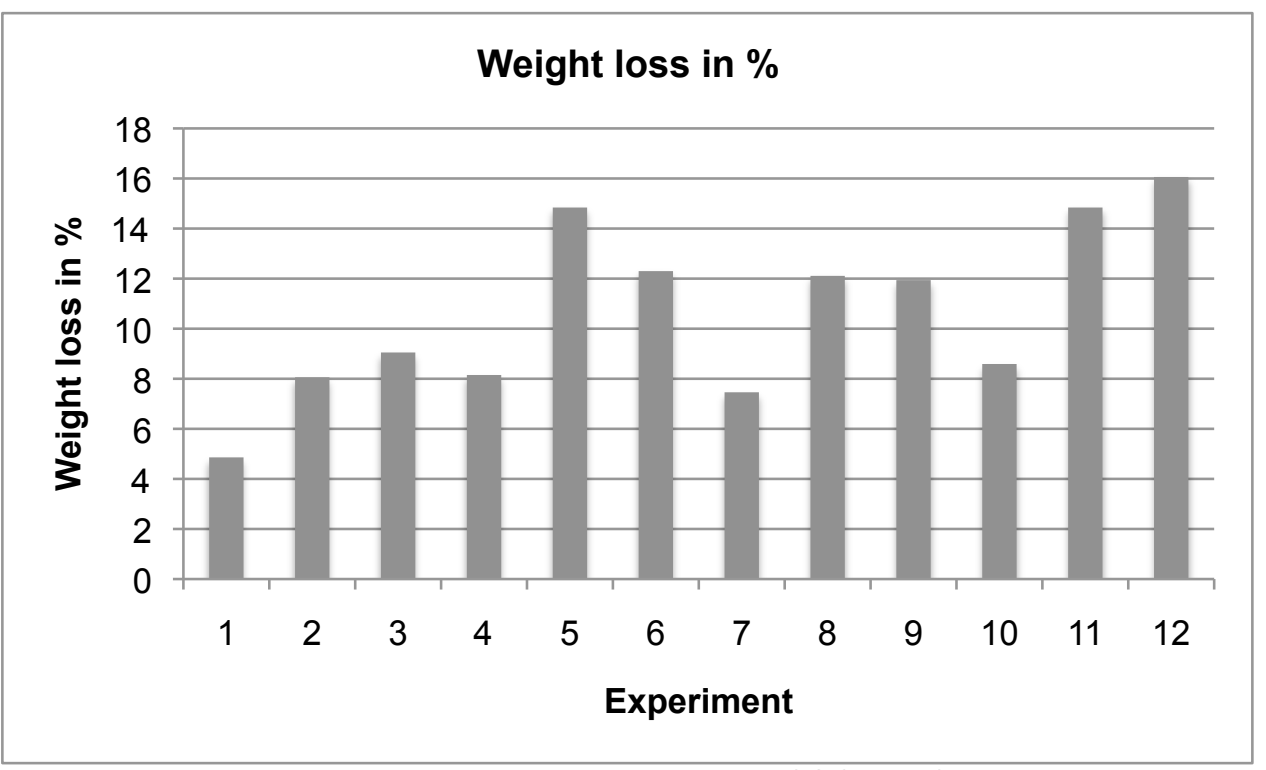

Figure 3.16: Experiments showing the weight loss of SCF's after treatment

In figure 3.16 the total weight loss has been shown. The total weight loss is the sum of the weight loss after the first rinse and the weight loss after the enzymatic treatment. The maximum total weight loss in these experiments is $16 \%$, which has been realized after rinsing, followed by enzymatic treatment with cutinase, xylanase and EDTA. The use of EDTA in a one bath treatment with pectinase shows an inhibitory effect on the performance of pectinase. Therefore this treatment is no option for one bath desizing/bio-scouring treatment [Agrawal, 2005]. The SCF's showed -in all experiments- a marginal weight loss.

To compare the results of the enzymatic treatment with the conventional treatments SCF's have been processed with $0,4 \mathrm{ml} / \mathrm{l} \mathrm{NaOH} 33 \%$ and $0,2 \mathrm{ml} / /$ Tanaterge Advance in a beaker-glass. The LCR was $1: 100$ and the treatment temperature was $95^{\circ} \mathrm{C}$. After rinsing and drying the SCF's have been climatized as it has been described before. After climatizing the samples have been 
weighed and the weight loss was calculated. The result of the conventional scouring of SCF's has been shown in table 3.6 for different process times.

\begin{tabular}{|c|c|}
\hline Process time in minutes & Weight loss in \% \\
\hline 1 & 5.69 \\
\hline 2 & 6.67 \\
\hline 3 & 14.44 \\
\hline 4 & 9.3 \\
\hline 5 & 9.3 \\
\hline 7 & 9.76 \\
\hline 10 & 9.12 \\
\hline 15 & 10.74 \\
\hline 20 & 13.72 \\
\hline 25 & 13.25 \\
\hline 30 & 16.30 \\
\hline
\end{tabular}

Table 3.6: Weight loss of SCF's after conventional treatment as a function of time

The weight loss shown in the table is the average weight loss of two experiments under the same conditions. It is believed that the weight loss variation was influenced by variation of the samples as the material is collected without any further treatment after ginning. The best enzymatic treatment gave the same result in terms of weight loss as conventional treatment after correcting the weight loss for water-soluble impurities $(4,8 \%)$. The result of the enzymatic treatment has been realized after 60 minutes incubation time, where the conventional treatment realized the same result after 30 minutes processing.

During the treatment it has been noticed that the hard shell of the seed coat weakens. After drying of the sample the hard shell of the SCF recovers. This effect is seen at both, enzymatic and conventional treatment.

The experiments, where the application of mechanical energy in continuous treatment is mimicked, have not been reported. Firstly the results were not reproducible due to dehydration of the fabric during treatment. The second reason was that no objective evaluation technique could be defined. Scanning for spot counting and colour measurement before and after treatment failed as the fabric was shrunk during the treatment.

\subsubsection{Conclusion on enzymatic SCF removal}

The results of the enzymatic treatment of SCF's do not justify a particular combination of enzymes and EDTA in an extra process step or adjustment of the enzyme cocktail as presented in section 3.7.5. These results confirm the findings of Csiszar, who concluded that the treatment of xylanase in the best case enhances the delignification of the subsequent alkaline scouring process [Csiszar et al. 2006]. In other work [Yan et al, 2009] a weight loss increase of 6 to $16 \%$ has been reported in a combined cutinase/pectinase treatment and even up to $36 \%$ in a combined cutinase/xylanase treatment where 24 hours incubation time at $55^{\circ} \mathrm{C}$ and a rinsing at the boil is carried out. Despite many experiments it was not possible to formulate an enzyme cocktail that showed sufficient degradation or removal of the SCF's. So the successive treatment steps enzymatic scouring and bleaching, as also concluded by Tavzer, remain necessary to remove or to decolorize SCF's from a fabric. 


\subsection{Conclusion}

An enzyme cocktail for one-bath desizing and bio-scouring of $100 \%$ cotton fabric has been selected. The cocktail consists of the enzymes a-amylase, cutinase and pectinase. The operating conditions for treatments with this cocktail are an impregnation and incubation temperature of $50^{\circ} \mathrm{C}$ at $\mathrm{pH} 8$ and a rinsing temperature of $30^{\circ} \mathrm{C}$. The performance indicators showed good results for size removal and degradation of wax and pectin on the tested fabrics.

The impregnation and the incubation temperatures for the enzyme cocktail were crucial for the performance of the treatment. At an impregnation and incubation temperature of $50^{\circ} \mathrm{C}$ the fabric has been rinsed at different temperatures. Evaluation of these experiments showed to our surprise that the performance of the pad batch treatment is independent of the rinsing temperature in the range of $30-50^{\circ} \mathrm{C}$. The rinsing at different temperatures after continuous treatment showed less independency of the rinsing temperature. It is believed that this is because the impregnation temperature here is much shorter and no mechanical energy is applied to the treated fabric.

Addition of the enzymes xylanase and cellulase to the enzyme cocktail did not improve the SCF degradation. After long incubation time and with the high concentrations of these enzymes only a marginal improvement of fragment removal has been noticed, based on the weight loss calculations. The bleaching step will play a dominant role in the removal of the SCF's.

The results of the enzymatic experiments for desizing and bio-scouring in one step treatments give a promising possibility for further successful development, because no mechanical energy is used yet, which will probably improve the performance. Further it seems to be likely that the performance indicators will improve after the consecutive bleaching treatment. So the enzyme cocktail will be the basis in the following development step where desizing and bio-scouring will be evaluated in combination with the bleaching step. 


\section{References}

AATCCC, Technical Manual, Volume 80, 2005

Abel, P., "The TEGEWA drop test, a method for the rapid determination of textile fabric absorption", Melliand Textilberichte, Volume 68 581-583, 1987

Agrawal, P., 'The performance of cutinase and pectinase in cotton scouring", ISBN 90-365-22439, Thesis University of Twente, the Netherlands, 2005

Agrawal, P., V.A. Nierstrasz, B.G. Klug-Santner, G.M. Guebitz, H.B.M. Lenting and M.M.C.G. Warmoeskerken, "Wax removal for accelerated cotton scouring with alkaline pectinase"' Biotechnology Journal, Volume 2, 306 - 315, 2007

Agrawal, P., V.A. Nierstrasz, G.H. Bouwhuis and M.M.C.G. Warmoeskerken, "Cutinase and pectinase in cotton bioscouring: an innovative and fast bioscouring process", Biocatalysis and biotransformation, Volume 26 (5), 412 - 421, 2008

Ahlawat, S., S.S. Dhiman, B. Battan, R.P. Mandhan and J. Sharma, "Pectinase production by Bacillus subtilis and its potential application in bio-preparation and micropoly fabric", Journal of Process Biochemistry, Volume 44, 521 - 526, 2009

Anis P., and H.S. Eren, " Comparison of alkaline scouring of cotton vs. alkaline pectinase preparation", AATCC website publication www.aatcc.org, 2002

Bach, E. and E. Schollmeyer, "Vergleich des Alkalischen Abkochprozesses mit der enzymatischen Entfernung der Begleitsubstanzen der Baumwolle", Textil Praxis International, Maerz, 1993

Biochemistry Bookshelf, $5^{\text {th }}$ Edition, www.ncbi.nlm.nih.gov/bookshelf/br.fcgi?book=stryer\&part=A1031

Buchholz, K., Kasche, V. and Bornscheuer, U.T., ' Biocatalysts and Enzyme Technology, ISBN 3-527-30497-5, Wiley-VCH Verlag GmbH \& Co KGaA, Weinheim Germany, 2005

Cavaco-Paulo A. and G.M. Gübitz, "Textile processing with enzymes", ISBN 1855736101 Woodhead Publishing, 2003

Csiszar E., Rusnak I. and Reicher J., "Wirksame alkalische Beuche der Baumwolle", Melliand Textil Berichte, Volume 6, P $411-415,1987$

Csiszar E., A. Losonczi, G. Szakacs, I. Rusznal, L. Bezur and J. Reicher, “Enzymes and chelating agent in cotton pre-treatment”, Journal of biotechnology, Volume 89, p 271 - 279 , 2001

Csiszár, E., A. Losonczi, B. Koczka, G. Szakács and A. Pomlényi, "Degradation of lignincontaining materials by xylanase in biopreparation of cotton", Biotechnol Lett, volume 28, 749753, 2006

Csiszar E., G. Szakacs and B. Koczka, "Biopreparation of cotton fabric with enzymes produced by solid-sate fermentation”, Enzyme and microbial technology, Volume 40, p 1765 - 1761, 2007 
Engbersen, J.F.J. and A.E. de Groot, "Inleiding in de bio-organische chemie", ISBN 9074134955, Wageningen Academic Publishers, Wageningen, the Netherlands, 2004

Eren H.A., P. Anis and A. Davulcu, "Enzymatic one-bath desizing bleaching dueing process for cotton fabrics", Textile Reearch Journal, Volume 79, p 1091 - 1098, 2009

Hebeish A., M. Hassem, N. Shaker, M. Ramadan, B. El-Sadek and M. Abdel Hady, “ New development for combined bio-scouring and bleaching of cotton-based fabrics", Carbohydrate Polymers, Volume 78, p 961 - 972, 2009

Herron, S.R., J.A.E. Benen, R.D. Scavetta, J. Visser and F. Jurnak, "Structure and function of pectic enzymes: Virulence factors of plant pathogens", Proc. Nat. Acad. Sci, USA, volume 97 (16) $8762-8769,2000$

Himmelsbach D.S., D.A. Akin, J. Kim, and I.R. Hardin, "Chemical structural investigation of the cotton fibre base and associated seed coat: Fourier-transform Infrared Mapping and histchemistry", Textile Research Journal, Volume 73, 281-288, 2003

Karapinar E., and Sariisik M.O., "Scouring of Cotton with Celllases, Pectinases and Proteases", Fibres and Textiles in Eastern Europe, Volume 12, Nr. 3 (47), 2004

Kolattukudy, P.E., "Plant cuticle and suberin", Encyclopedia of life sciences, Nature Publishing Group, www.els.net, 2001

Losonczi, A., E. Csiszar, G. Scakacs and L. Bezur, "Role of the EDTA Chelating agent in Bioscouring of Cotton"' Textile Research Journal, Volume 75, p 411 - 417, 2005

McMurry, J.E. and R.C. Fay, "Chemistry", ISBN 978-0-13-232146-4, Pearson Education Inc, 2008

Miller, B. and I. Tyomkin, "Liquid porosimetry: New methodology and applications"', Journal of Colloid and interface Science, volume 162, 163-170, 1994

Mueller, A., "Nachweis von staerke Schlichte", Tanatexchemicals, lab-instruction, 1997

Opwis, K., D. Knittel, A. Kele, and E. Schollmeyer, "Enzymatic recycling of starch-containing desizing liquors", Starch/Staerke, Volume 51, Nr. 10, 348-353, 1999

Ramadan, A.R., "Characterization of biobleaching of cotton/linen fabrics",Journal of Textile and Apparal, Technology and Management, Volume 6, Issue 1, 2008

Rouette H.K., "Encyclopedia of Textile Finishing”, ISBN 3-540-65031-8, Springer Verlag Berlin/Germany, 2001

Sangwatanaroy U., and K. Choonukulpung, "Cotton scouring with pectinase and Lipase/Protease/Cellulase”, www.aatcc.org, May, 2003

Tavcer, P.F., "The influence of different pre-treatments on the quantity of seed coat fragments in cotton fibres", Fibres and Textiles in Eastern Europe, Volume 16, 19 - 23, 2008

Topalovic, T., "Catalytic bleaching of cotton: Molecular and macroscopic aspects", ISBN 90-3652454-7, Thesis University of Twente, the Netherlands, 2007 
Tzanov, T., M. Calafell, G.M. Gübitz and A. Cavaco-Paulo, "Bio-preparation of cotton fabrics", Enzyme and Microbial Technology, Volume 29, 357-362, 2001

www.sc.ehu.es/qpwaiipj/PDF/R Lopez/Chapter\%201.\%20General\%20Aspects.pdf, last time visited July $1^{\text {st }}, \mathbf{2 0 1 0}$

Yan, H., Z. Hua, G. Qian, M. Wang, G. Du and J. Chen, "Effect of cutinase on the degradation of cotton seed coat in Bio Scouring", Biotechnology and Bioprocess Engineering, Volume 14, 354360, 2009 


\section{Sustainable bleaching}

Conventional bleaching is compared in this chapter with new developments in bleaching. Promising developments are catalytic bleaching and in situ formed bleaching agents.

Evaluation of the experiments showed that low alkali peroxide bleaching in combination with enzymatic desizing and scouring shows promising results. The manganese based bleaching catalyst is used for the activation of hydrogen peroxide. Experiments show that a substantial reduction of the rinsing temperature after bleaching is possible. 


\subsection{Introduction}

Textile pre-treatment processes consist of three steps. The first step is desizing, the second step is scouring and the third step is bleaching. The aim of the bleaching step is the whitening of the fabric. So that for dyeing or printing an even white, hydrophilic and reproducible fabric is available. It has to be mentioned that in a conventional treatment during the bleaching step also a further improvement of desizing and hydrophilicity is achieved (see also chapter 3). An even white and reproducible bleached fabric is a requirement of the dyeing or printing company. The final colour of a fabric is a function of the concentration of the dyes, the dyeing process and the 'basic' colour of the fabric. Differences in the basic colour lead to differences in the colour after dyeing. To achieve an even white and reproducible fabric different bleaching steps can be performed.

\subsection{Current conventional bleaching processes}

\section{Processing and installed base}

In industry there are three major bleaching processes, which are a part of the complete pretreatment of cotton.

The major industrial bleaching processes are:

- pad batch - hot bleach;

- continuous bleaching;

- discontinuous bleaching.

\section{Pad batch - hot bleach}

This industrial process consists of two separate steps. In the first step the greige fabric is singed, impregnated with a desizing solution and consecutive the fabric is rolled on an A-frame and incubated for several hours. The fabric is rinsed in hot water to remove hydrolyzed starch. After rinsing the fabric is cooled down and impregnated with the bleaching solution, which consists $\mathrm{H}_{2} \mathrm{O}_{2}, \mathrm{NaOH}$, detergents and bleach-stabilizer. The fabric is guided into a steamer after impregnation, where it dwells during $15-20$ minutes at $100^{\circ} \mathrm{C}$ and $100 \%$ relative humidity. Here the bleaching reaction takes place. Thereafter the fabric is guided into the rinsing compartments to wash out the reaction products and residual bleaching agents. The fabric is soured in the last rinsing compartment to neutralize residual $\mathrm{NaOH}$. Finally the fabric is dried. The installed base for this process has been schematically drawn in fig. 2.7. So in this process the scouring and bleaching step are combined into one 'hot bleach step'. The consequence for this combination is that extra chemicals are needed to realize sufficient removal of hydrophobic matter and whiteness. This harsh process results in more cotton damage and a firm hand of the fabric. Advantage of this process is a smaller installed base and less capital investment. About $60 \%$ of the global volume of full width pre-treated cotton is performed according this process [private communication with Benninger, 2005].

\section{Continuous bleaching}

The continuous bleaching of cotton consists of three different sub processes. The first and second sub-process are desizing and scouring. The fabric is rinsed in water of $100^{\circ} \mathrm{C}$ after 
scouring to wash out the reaction-products from wax and pectin after saponification/hydrolyzing with $\mathrm{NaOH}$. After the rinse the fabric is cooled down and consecutively impregnated with the bleaching agents $\mathrm{H}_{2} \mathrm{O}_{2}, \mathrm{NaOH}$, detergent and stabilizer. The fabric is -after impregnation- guided into the steamer where the bleach-reaction takes place. The process conditions in the steamer are $100^{\circ} \mathrm{C}$ and $100 \%$ relative humidity. After the incubation in the steamer the fabric is guided into the rinsing compartments. Here rinsing takes place at $100^{\circ} \mathrm{C}$. In the last rinsing compartment the fabric is soured and rinsed at $60^{\circ} \mathrm{C}$. The installed base for this process is schematically drawn in fig. 2.6. In this process the bleaching takes place with lower concentration of bleaching agents as the saponification/hydrolyzation of the cotton wax and pectins has already been done during scouring. Advantage of this process, -compared to pad batch - hot bleach, is that here is impregnated with lower concentrations of bleaching agents. This results in less cotton damage and reduced chemical costs. The handle of the fabric is generally characterized as more soft. On the other hand the capital investment for this installed base is higher. About $10 \%$ of the global volume of pre-treated cotton is treated according this process [private communications with Benninger, 2005].

\section{Discontinuous bleaching}

Discontinuous bleaching is mostly carried out on a jigger or a jet. On a jigger the fabric is treated on full width. In a jet the treatment is done in rope form. On this equipment the three subprocesses are carried out sequentially, beginning with desizing, followed by scouring ad finally bleaching. Here also combinations of sub-processes are possible. The general process conditions for desizing and rinsing are incubation and rinse at $80-90^{\circ} \mathrm{C}$. Scouring and bleaching is normally done in one bath at $80-95^{\circ} \mathrm{C}$. After bleaching a peroxide neutralizer is added to avoid residual peroxide in the dyeing bath.

A dyeing process often follows discontinuous pre-treatment. Drying after bleaching can be passed. The reproducibility of this process is less compared to continuous processing. Discontinuous pre-treatment of cotton takes several hours per batch. Water and energy efficiency is in general less than in continuous processing. On the other hand the investment in equipment is substantially lower.

The aim of this work is the development of a new industrial continuous pre-treatment process. Therefore discontinuous pre-treatment is not further discussed for lab scale experiments.

It can be concluded that the process conditions for the continuous bleaching step takes place at $100^{\circ} \mathrm{C}$ in a steamer, filled with water-saturated air. High concentrations of harsh chemicals are used. After bleaching the removal of the chemicals is pre-requisite for further treatment.

\section{Bleaching agents}

The most widely used bleaching agent is $\mathrm{H}_{2} \mathrm{O}_{2}$. In the past other bleaching agents as sodium hypochlorite $(\mathrm{NaOCl})$ and sodium chlorite $\left(\mathrm{NaClO}_{2}\right)$ are used, but based on environmental consequences the use of these bleaching agents is reduced and $\mathrm{H}_{2} \mathrm{O}_{2}$, particularly for cotton, is therefore the most used bleaching agent.

During bleaching the natural colorants of cotton have to be removed or to decolorized. The chemical constitution of the natural colours of cotton has been described in Chapter 2. During 
the bleaching process the natural colorants of cotton are oxidized, which causes the whitening of the fabric.

$\mathrm{H}_{2} \mathrm{O}_{2}$ is a chemical compound, that reacts as an oxidising agent in most cases. It also has a reducing effect against very powerful oxidising agents as potassium permanganate. This reaction is used for determining residual $\mathrm{H}_{2} \mathrm{O}_{2}$ content in the bleaching or rinsing bath after bleaching. $\mathrm{NaOH}$ is used in the bleaching process to activate decomposition of $\mathrm{H}_{2} \mathrm{O}_{2}$. The decomposition of $\mathrm{H}_{2} \mathrm{O}_{2}$ is in alkaline medium at $\mathrm{pH} 10-10,5$ and at a steamer temperature of $100^{\circ} \mathrm{C}$. Stabilizers are of utmost importance as temperature and an alkaline environment sharply increase the decomposition rate of $\mathrm{H}_{2} \mathrm{O}_{2}$ in an uncontrollable way causing uneven bleached fabric and a substantial risk of fibre damage in the cotton fabric. Stabilizing $\mathrm{H}_{2} \mathrm{O}_{2}$ in the bleaching liquor is of decisive importance to obtain a uniform bleaching result and maximum gentle treatment of the cotton fabric [Rouette, 2001]. Cotton is contaminated with ferric ions, $\mathrm{Fe}^{2+}$ and $\mathrm{Fe}^{3+}$. This contamination occurs during grow and treatment for instance in a spinning or weaving mill. Also the pre-treatment installed base can contaminate cotton with $\mathrm{Fe}^{2+}$ or $\mathrm{Fe}^{3+}$ ions. The ferric ions cause catalytic damage as $\mathrm{OH}$ radicals are produced that are highly oxidative. Stabilizers often contain sequestering agents. The addition of sequestering agents is necessary to reduce the risk of catalytic damage of cotton during bleaching. The radical chain reaction can be explained by the Haber-Weiss mechanism with the example of bivalent iron:

Start: $\quad \mathrm{Fe}^{2+}+\mathrm{HOOH} \rightarrow \mathrm{Fe}^{3+}+{ }^{\circ} \mathrm{OH}+\mathrm{OH}^{-}$

Chain: $\quad \mathrm{OH}^{\circ} \mathrm{HOOH} \rightarrow \mathrm{H}_{2} \mathrm{O}+\mathrm{HOO}^{\bullet}$

$$
\begin{aligned}
& \mathrm{Fe}^{2+}+\mathrm{HOO}^{\circ} \rightarrow \mathrm{Fe}^{3+}+\mathrm{HOO}^{-} \\
& \mathrm{Fe}^{3+}+\mathrm{HOO}^{\bullet} \rightarrow \mathrm{Fe}^{2+}+\mathrm{O}_{2}+\mathrm{H}^{+}
\end{aligned}
$$

End: $\quad \mathrm{Fe}^{2+}+{ }^{\circ} \mathrm{OH} \rightarrow \mathrm{Fe}^{3+}+\mathrm{OH}^{-}$

This mechanism applies to both iron(II) and iron(III) ions. For the activity of a catalyst, i.e. for the quantity of $\mathrm{H}_{2} \mathrm{O}_{2}$ decomposed in the unit of time, not only the type, the surface, the particle size and its structure are of prime importance, but also the $\mathrm{pH}$ of the liquor, its temperature and the concentration of the peroxide.

Besides the oxidizing effect due to its greater oxidation potential, the $\mathrm{OH}$ radical in a subsequent chain reaction enters into radical reactions with $\mathrm{H}_{2} \mathrm{O}_{2}$ and organic compounds, which cause their oxidation and breakdown as described above. The most frequently used stabiliser systems are organic stabilisers based on phosphoric acids, aminocarboxylates and sodium silicate (waterglass) in combination with earth alkaline ions like magnesium ions. The stabilising effect is based on the fact that $\mathrm{H}_{2} \mathrm{O}_{2}$ decomposition metals like $\mathrm{Fe}$ are scavenged in stabilizers like waterglass. Besides this the magnesium ions form colloids, which act as a buffer and keeps the liquor alkalinity constant. 


\section{The bleaching process}

Before impregnation of the fabric with the bleaching agents the fabric is rinsed at $100^{\circ} \mathrm{C}$. Prior to the impregnation with the bleaching agents the fabric is cooled down to a temperature below $40^{\circ} \mathrm{C}$. This is done to avoid pre-decomposition of $\mathrm{H}_{2} \mathrm{O}_{2}$. After impregnation of the fabric with the bleaching liquor the fabric is guided into the steamer, where the bleaching reaction takes place. The natural colourants of cotton are oxidized and loose their colour. Oxidation of the natural pigments in cotton is the result of decomposition of $\mathrm{H}_{2} \mathrm{O}_{2}$ into perhydroxyanions. During bleaching high amounts of $\mathrm{NaOH}$ are used as bleach-activator in alkaline medium at $\mathrm{pH} 10-11$. The chemical reactions in the bleaching liquor are:

$\mathrm{H}_{2} \mathrm{O}_{2}+\mathrm{NaOH} \longleftrightarrow \mathrm{H}_{2} \mathrm{O}+\mathrm{Na}^{+}+\mathrm{HO}_{2}^{-}$

$2 \mathrm{HO}_{2}^{-} \longleftrightarrow \mathrm{O}_{2}+2 \mathrm{OH}^{-}$

In conventional pad batch - hot bleach pre-treatment the enzymatic step consists of impregnation with a desizing agent (amylase) and detergents. During the bleaching step extra $\mathrm{NaOH}$ and $\mathrm{H}_{2} \mathrm{O}_{2}$ is added to the bleaching liquor. This is necessary because during the bleaching activity also saponification and degradation of the waxes respective the pectins takes place. The quantities of chemicals that are necessary in this step, makes it a very harsh process. The chemical treatment with extra $\mathrm{NaOH}$ causes an extra loss of quality, resulting in degradation of the degree of polymerization and a firm handle of the fabric.

After bleaching the residual $\mathrm{NaOH}$ has to be rinsed from the fabric. As $\mathrm{NaOH}$ 'sticks' to the fabric it is necessary to rinse with high amounts of water at boiling temperature. After rinsing the fabric is soured to neutralize residual $\mathrm{NaOH}$ and to obtain a neutral to slight acidic fabric. For acidification acetic acid is used frequently. Insufficient rinsing of $\mathrm{NaOH}$ before acidification can lead to precipitation of sodium acetate on the fabric, which causes later uneven dyeing. On the other hand residual $\mathrm{NaOH}$ in the fabric can cause yellowing of the white fabric during storage before dyeing. A good process control will avoid these unwanted side effects.

Overall conventional bleaching is characterized by high concentrations of bleaching agents that are used at high incubation and rinsing temperatures. Therefore the environmental responsibility of industry and scientists requires the development of a sustainable bleaching process at low temperatures.

\subsection{Colour measurement}

Evaluation of colour is very difficult. Colour is subjective and has a direct sensory effect on people. It affects emotions and can convey any mood. As colour is a sensation it is a unique personal experience and two individuals do not see or share the same perception of any given colour. This aspect of colour judging makes it almost impossible to evaluate a colour objectively and this resulted in developing a device to measure colours objectively and that made it possible to communicate about colours. Nowadays a reflectance spectrophotometer is used in textile industry to measure colours for evaluation.

In 1611 the Swedish monk and astrologer Sigrid Aron Forsius proposed a three-dimensional colour arranging system. This system still is the base for all other systems. 
In 1931 the International Commission on Illumination established a system for objective colour specification called colorimetry. The CIE-XYZ system is based on additive colour blending. The major colours are placed in the angular points of an equilateral triangle. The major colours are blue $(435,8 \mathrm{~nm})$, green $(541,6 \mathrm{~nm})$ and red $(700 \mathrm{~nm})$ and they can be plotted in a threedimensional colour model. In the model the colour blue is represented by $Z$, the colour green is represented by $\mathrm{Y}$, and the colour red is represented by $\mathrm{X}$. This system creates the opportunity to give any colour a unique value. The system is based on the visual capabilities of a standard observer. This hypothetical observer is derived from the CIE's extensive research of the human vision. Collective results of colour-matching experiments have been used to create 'colourmatching functions' and a 'universal colour space' that represents the average human's range of visible colours. The colour-matching functions are the values of each light primary (red-greenblue) that must be present for the average human visual system to perceive all the colours in the visible spectrum. The $X Y Z$ colour-space is translated into most widely used CIE L*a*b* model. The structure of the $L^{*} a^{*} b^{*}$ colour space is based on the theory that a colour cannot be both green and red at the same time, nor blue and yellow at the same time. This results in the description red/green and yellow/blue attributes. In the CIE $L^{*} a^{*} b^{*}$ model $L^{*}$ defines lightness, $a^{*}$ denotes the red/green value and $b^{*}$ denotes the yellow/blue value. In the model $L^{*}$, represented on the L-axis, is graded from 0 (black) to 100 (white). On the $a^{*}$-axis -60 stands for green and +60 stands for red. On the $b^{*}$-axis -60 stands for blue and +60 stands for yellow. The three $L^{*} a^{*} b^{*}$ axis', that are perpendicular located, describe an elliptic space in which all colours fit.

Measurement of the colour white is based on the CIE-XYZ system in which the colorimetric coordinates are measured. White differs from the chromatic colours in that way that white products show a high degree of brightness combined with very low colour saturation, the chromaticity of white, in other words, is very weak.

To calculate the degree of whiteness different formulas are developed [Rouette, (Ed.), 2001]:

- direct measured physical values, e.g. Stephansen. The formula reads: $W_{s t}=2{ }^{*} R_{46}-R_{62}$ This formula cannot be applied for optical brighteners;

- whiteness formula, which are based on colour values;

○ Berger-formula. The Berger formula reads: $W_{B}=Y+3.448 * Z-3.904{ }^{*} X$;

- ClE-whiteness formula: $W=Y+800(0.3138-x)+1700(0.3310-y)$ and for the colour cast (tint) CIE recommends: $T=900(0.3138-x)-650(0,3310-y)$.

For lab-experiments the Berger formula for whiteness is used. The Berger-whiteness formula is based on colour values that correspond best with the characteristics of the human eye. In industry both, Berger and CIE-whiteness formula are used. In general a whiteness according Berger of 70 to 75 is accepted for full white fabric. For optical white a whiteness of 80 till 85 according to Berger is required. This extreme whiteness is not realized by bleaching, but with the aid of so-called optical whiteners. The optical whiteners are not discussed, as they do not form part of this research.

In this research the X-Rite Basic Eye $4.5 \mathrm{~mm}$ spectrophotometer has been used. The light source is D65, the angle for measurement $10^{\circ}$. All measurements are expressed in whiteness index according Berger. 


\subsection{New developments in the bleaching process}

Sustainable pre-treatment consists of two major process steps. The first process step is desizing and scouring, which in fact means the preparation of the substrate for the following sub-process in pre-treatment, which is called bleaching. In Chapter 3 we showed that an enzyme cocktail containing amylase, cutinase and pectinase gives sufficient size, wax and pectin removal after the first step before bleaching. To upgrade the bleaching step to a sustainable process the following methods have been explored:

1. reduction of quantity chemicals by in situ formation of $\mathrm{H}_{2} \mathrm{O}_{2}$ by using glucose as a substrate and glucose-oxidase enzyme;

2. in situ production of peracetic acid with aryl-esterase as enzyme and $\mathrm{H}_{2} \mathrm{O}_{2}$ as substrate;

3. improvement of sustainability by reducing reaction- and rinsing temperature with the use of catalysts.

\subsubsection{In situ formation of $\mathrm{H}_{2} \mathrm{O}_{2}$}

The most common bleaching agent that is used in high quantities is $\mathrm{H}_{2} \mathrm{O}_{2}$. The enzyme glucoseoxidase generates in situ $\mathrm{H}_{2} \mathrm{O}_{2}$ in the presence of oxygen using glucose as substrate. The degradation product of starch is glucose, which is rinsed out after enzymatic desizing. Advantage of this approach is that also gluconic acid is formed during the enzyme reaction. Gluconic acid acts as chelator for metal ions and the addition of $\mathrm{H}_{2} \mathrm{O}_{2}$-bleach stabilizers can be avoided. Implementation of these processes is beneficial in terms of reduced water and chemical consumption. The effluent after desizing will be less polluted as degraded starch is reused. The bleaching effluent will also be less polluted as no stabilizer is added for bleaching [Opwis et al., 1999]. Despite the advantages as mentioned before, this process is not industrially adapted. One of the reasons is the cost of enzymes. The enzymes are immobilized to reduce the costs. Immobilization enables reuse of enzyme in consecutive treatments. Enzymes can be immobilized on various insoluble carriers. Tzanov immobilized glucose-oxidase on aluminium oxide pellets and on glass (glass foam pellets) [Tzanov et al., 2002]. Immobilized enzymes on glass pellets gave initially higher $\mathrm{H}_{2} \mathrm{O}_{2}$ production. However after repeated usage of immobilized enzyme a decreasing production of $\mathrm{H}_{2} \mathrm{O}_{2}$ is noticed. The alumina support showed good resistance under the same reaction conditions and was therefore selected for further experiments. It is shown that sufficient $\mathrm{H}_{2} \mathrm{O}_{2}$ is formed. Disadvantage of this process is that in situ forming of peroxide requires a slight acidic medium for optimal enzyme activity. This means that for in situ forming of $\mathrm{H}_{2} \mathrm{O}_{2}$ an extra process step is required. This is confirmed by the experiment that only for conventional alkaline bleaching conditions at $\mathrm{pH} 11$ a sufficient whiteness was achieved. In combined desizing, scouring and bleaching it is established that higher quantities of $\mathrm{H}_{2} \mathrm{O}_{2}$ are necessary. It is believed that bath impurities consume an important part of the in situ produced bleaching agent. Besides the latter draw back researchers also found that repeated experiments showed insufficient reproducibility. Therefore this method is not further explored in this study. 


\subsubsection{Bleaching with in situ formed peraceticacid}

Peraceticacid is known for its cotton bleaching properties in mild conditions. The process conditions are $\mathrm{pH} 8.2$ and the temperature between 60 and $80^{\circ} \mathrm{C}$. The risk of catalytic damage is not evident under the described conditions as no radicals are formed. Despite these properties peraceticacid is not used in textile industry. The major reason is not the classification 'explosive' as often is assumed. The first hesitation to use peraceticacid is the handling and the mixing of the chemicals. The second hesitation is the narrow $\mathrm{pH}$ range in which the processing has to take place. The range varies from $\mathrm{pH} 7$ to $\mathrm{pH}$ 9. In neutral to slight acidic environment no bleaching occurs. In alkaline environment, above $\mathrm{pH} 9.2$ extreme and uncontrollable bleaching with high risk of fibre damage takes place. In continuous bleaching it is necessary to use steamers with a so-called water lock to avoid the entrance of oxygen from the air into the reaction chamber. The bleaching properties of peraceticacid are not as good as $\mathrm{H}_{2} \mathrm{O}_{2}$. Especially the whiteness and removal of seed husks is evidently less. Nevertheless until now peraceticacid is a candidate for mild bleaching treatment especially when not a full white is required. In search to improve the sustainability of the pre-treatment of cotton researches worked on the development of in situ formed peraceticacid bleaching. Researchers followed two strategies for in situ forming of peraceticacid.

One strategy is to form peraceticacid via the reaction of tetraacetylethylenediamine (TAED) and $\mathrm{H}_{2} \mathrm{O}_{2}$ [Hebeish et al., 2007]. For experiments different cotton and cotton-blended fabrics have been used. It is concluded that increasing TAED concentration gives a better whiteness. The process conditions are interesting concerning $\mathrm{pH} 8$ and temperature $40-70^{\circ} \mathrm{C}$. Despite these ambient conditions this process is not suited for continuous treatment due to long reaction time for in situ forming of peraceticacid (60 - 120 minutes), where the time for bleaching in continuous processing is maximum 20 minutes. The combined bio-scouring and bleaching shows no improvement of WI in their study.

In the second strategy the researchers followed the route to produce in situ peraceticacid with the use of enzymes. Aryl-ester hydrolase (EC 3.1.1.2) has been used with propylene glycol diacetate and $\mathrm{H}_{2} \mathrm{O}_{2}$. The enzyme arylesterase is highly specific to perhydrolysis and thus stimulating the forming of peraceticacid under mild conditions $\left(\mathrm{pH} 8,65^{\circ} \mathrm{C}\right)$. Due to the long treatment time this process is not suited for continuous treatments. Discontinuous treatment of cotton shows promising results [Rupp, 2009].

\subsubsection{Bleaching with catalytic decomposed $\mathrm{H}_{2} \mathrm{O}_{2}$}

For bleaching with $\mathrm{H}_{2} \mathrm{O}_{2}$ it is required that decomposition of peroxide takes place. In principle $\mathrm{H}_{2} \mathrm{O}_{2}$ dissociates in an aqueous medium only slightly. The dissociation reaction is described as follows:

$$
\mathrm{H}_{2} \mathrm{O}_{2} \underset{\leftarrow}{\rightarrow} \mathrm{H}^{+}+\mathrm{HO}_{2}^{-}
$$

Activation of the $\mathrm{H}_{2} \mathrm{O}_{2}$ solution with $\mathrm{NaOH}$ moves the dissociation equilibrium to the right and the concentration of perhydroxyanions is increased. 
$\mathrm{H}_{2} \mathrm{O}_{2}+\mathrm{OH}^{-} \stackrel{\rightarrow}{\leftarrow} \mathrm{H}_{2} \mathrm{O}+\mathrm{HO}_{2}^{-}$

It is believed that the bleaching reaction occurs via a superoxide anion radical. Parallel to this a self-decay takes place in a secondary reaction that has no effect on the bleach and results in the formation of oxygen and water. Increasing decomposition results in increasing bleaching reaction and self-decay as a competing reaction decreases.

A number of factors have urged researches to search for improved methods for cotton bleaching. The first aspect is the cost of bleaching. Until now bleaching is performed at high temperature, varying from 70 to $100^{\circ} \mathrm{C}$, for respectively discontinuous and continuous bleaching. The second aspect is the need of wastewater reduction. It is likely that the use of small quantities of bleach catalysts compared to high quantities $\mathrm{NaOH}$ will reduce the effluent but also the waste load of the effluent.

The requirements for catalytic bleaching agents are:

- oxidative stability;

- hydrolytic stability;

- sufficient activation of $\mathrm{H}_{2} \mathrm{O}_{2}$;

- fibre damage comparable or less than conventional systems;

- reduced energy demand;

- applicable in alkaline conditions.

For cellulose bleaching there are three groups of transition-metal bleach catalysts for pulp bleaching and laundry cleaning applications reviewed [Hage \& Lienke, 2006].

\section{Manganese bleaching catalysts}

Manganese salts

In the mid 80'ies manganese salts are claimed as $\mathrm{H}_{2} \mathrm{O}_{2}$ decomposition activators. Good bleaching activity at $40^{\circ} \mathrm{C}$ is reported by using a tea-model stain. The potential application however is limited due to deposition of the manganese dioxide on the fabric. The salt precipitates out as brown $\mathrm{MnO}_{2}$ on the fabric. The use of manganese-exchange zeolites enhances a slow release of the manganese ions. The slow release of manganese ions reduces the deposition of these ions on the fabric.

\section{Manganese-triazocyclononane complexes}

In 1988 the first bleaching agent containing a dinuclear manganese compound containing 1,4,7trimethyl-1,4,7-triazocyclononane ligand has been published (figure 4.1) as a model to study manganese-containing enzymes [Wieghardt et al., 1988]. 


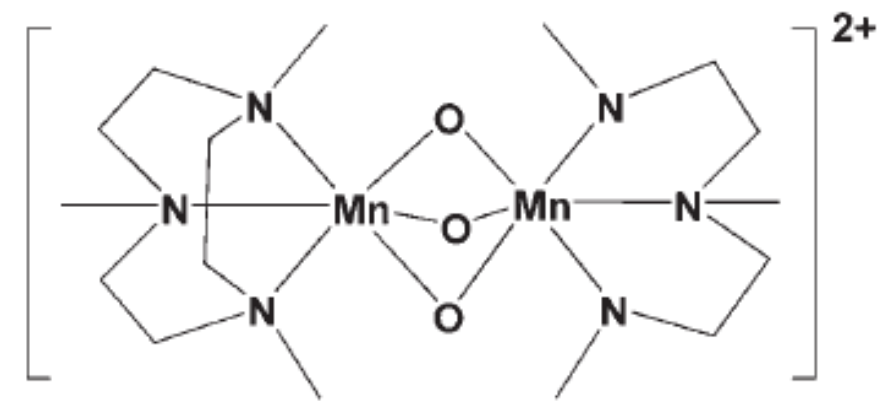

Figure 4.1: Scheme of 1,4,7-trimethyl-1,4,7-triazocyclononane ligand

Manganese-TACN complexes are claimed to be efficient, selective oxidation catalysts at room temperature and they are stable in alkaline conditions. No manganese precipitation occurs because the manganese-TACN complexes form homogeneous and stable complexes. The mechanism of the oxidation is described as a two-step process by using phenolic compounds and catechol as models for tea-stains. The first step involves a rapid overall one-electrontransfer process from the phenolate ion to the $\mathrm{Mn}^{\mathrm{IV}} \mathrm{Mn}^{\mathrm{IV}}$ species to give initially a $\mathrm{Mn}^{\text {III }} \mathrm{Mn}^{\text {IV }}$ species. This species can be detected by EPR (Electron Paramagnetic Resonance) at its typical 16 peaks spectrum. In the second step the dimeric $\mathrm{Mn}^{\mathrm{III}} \mathrm{Mn}^{\mathrm{IV}}$ species is ultimately converted to monomeric $\mathrm{Mn}^{\prime \prime}$, whereas the addition of $\mathrm{H}_{2} \mathrm{O}_{2}$ regenerates active oxidant. The nature of active oxidants in the catalytic system is not yet identified. It is speculated that possible candidates are high-valent mono- or dinuclear MnTACN complexes, including their oxo, hydroperoxo or $\mu$ peroxo derivates.

The dinuclear complex is stable against hydrolysis, thus reduction is required for monomer formation. In the second step, oxidation to $\mathrm{Mn}^{\mathrm{IV}}$ or $\mathrm{Mn}^{\mathrm{V}}$ species is assumed, which can either be mono- or dinuclear. Comparison with the $\mathrm{pH}$-dependant stain bleaching activity of [Mn ${ }^{\mathrm{IV}} \mathrm{Mn}^{\mathrm{III}}(\mu$ O) $\left.)_{2}\left(\mu-\mathrm{CH}_{3} \mathrm{COO}\right)\left(\mathrm{Me}_{4} \mathrm{dtne}\right)\right]^{2+}$, which contains a stable dinuclear $\mathrm{Mn}^{\mathrm{III}} \mathrm{Mn}^{\mathrm{IV}}$ core, led to the conclusion that both mononuclear and dinuclear $\mathrm{Mn}-\mathrm{Me}_{3} \mathrm{TACN}$ species are operative. ESI-MS (Electrospray lonisation Mass Spectrometry) is used the find evidence for other intermediates than EPR-detectable species. In the regeneration process it is found that mononuclear $\mathrm{Mn}$ (II) is oxidised to $\mathrm{O}=\mathrm{Mn}^{\vee}$ species, which has been proposed as being the active oxidant. Nevertheless no evidence is found for the presence of $\mathrm{O}=\mathrm{Mn}^{\mathrm{V}}$ in the azo-dye oxidation by $\mathrm{MnTACN} / \mathrm{H}_{2} \mathrm{O}_{2}$ using ESI-MS. It was suggested that the reaction of the azo-dye anion, MnTACN and HOOleads to a breakdown of the dinuclear MnTACN to give reactive mononuclear species. It is unclear whether these are $\mathrm{Mn}(\mathrm{II}), \mathrm{Mn}(\mathrm{IV})$ or $\mathrm{Mn}(\mathrm{V})$.

Iron based bleaching catalysts

The iron complexes with Tris(pyridine-2methyl)amine (TPA), Pentadentate Nitrogen-Donor ligands and macrocyclic tetra-amidate ligands are potential bleaching catalysts [Hage \& Lienke, 2006]. Iron complexes with TPA as ligand were patented to be activators for peroxy compounds and thus to yield substrate oxidation. This includes dye-bleaching in solution as well as a modest stain bleaching, both in the presence of peroxide. Stain bleaching is used as a model for bleaching of cotton. Iron complexes with pentadentate nitrogen donor ligands show superior 
catalytic activity compared to iron complexes with TPA as ligand. Iron complexes with macrocyclic tetraamidate ligands show good performance in solution bleaching in presence of peroxide. Iron based catalysts did not show formation of hydroxyl radicals. So no catalytic damage is expected as no hydroxyl radicals are formed.

\section{Cobalt based bleaching agents}

Some patents concerning cobalt-based activation of peroxide have been filed. One group describes cobalt penta-amine complexes and the other cobalt complexes with polypyridineamine ligands [Hage \& Lienke, 2006]. The mechanism of peroxide colbalt acvtivation is not known and on industrial scale no experiments are reported in pre-treatment of cotton. Therefore this cobalt activated bleaching is not discussed further.

Various transition-metal complexes have been evaluated for bleaching applications. MnTACN showed effective catalysis for hydrogen peroxide low temperature bleaching and meets the requirements for bleach catalysts as described before in this chapter [Topalovic, 2007].

\section{Catalaytic bleaching with MnTACN}

Extensive research on the bleaching catalyst MnTACN showed sufficient $\mathrm{H}_{2} \mathrm{O}_{2}$ activation at $30^{\circ} \mathrm{C}$ [Topalovic, 2007]. The research has been performed in three steps. The first step is microscopic evaluation of the effectiveness of the MnTACN catalyst under homogeneous conditions. In the experiments morin has been used as model-substrate. The second step included experiments in heterogeneous conditions, where first completely pre-treated and thus perfect white and clean cotton has been stained with morin. After these experiments desized and two times conventional scoured cotton has been bleached. The extra treatments have been carried out to analyse the effect of catalytic bleaching and to avoid side effects as residual desizing and degradation of waxes and pectins.

Topalovic showed the effectiveness of catalytic bleaching with $\mathrm{MnTACN}$ at $30^{\circ} \mathrm{C}$ and $\mathrm{pH} 10.2$. It gave a profound insight in the kinetics of catalytic bleaching based on homogeneous and heterogeneous conditions concerning the bleaching step in the pre-treatment of cotton. The whiteness of the fabric was sufficient and comparable with bleached fabric under conventional conditions. Fibre damage observed was comparable to that of conventional bleaching [Topalovic, 2007]. The starting point for incorporation of catalytic bleaching and enzymatic desizing/scouring is the exploration of a one or two-step pre-treatment process for cotton. The experiments will be evaluated for the desizing, scouring and bleaching performance. For the bleaching performance the colour of the bleached fabric will be measured and compared with the benchmark. The other evaluation techniques have already been discussed in Chapter 3 .

\subsection{Experimental}

Textile fabric is bleached in either full width form or in rope form. In this work bleaching is tested in full width form. This is the most common process for bleaching as the risk of creating rope creases is excluded. Rope creases cannot be identified during bleaching or after bleaching, but

they are noticed after dyeing as dark stripes in the fabric. In full width form the bleaching is done 
in discontinuous and continuous installed base. In general small batches are bleached in discontinuous installed base e.g. a jigger for full width or a jet for rope treatment. The process for full width pre-treatment installed base consists of impregnation with the bleaching liquor and reaction of the fabric in a steamer. Here the decomposition of $\mathrm{H}_{2} \mathrm{O}_{2}$, takes place, the so-called bleaching. After bleaching the fabric is rinsed to wash out impurities and residual bleaching agents. The fabric is often soured in the last rinsing compartment. Acidification is necessary to neutralize residual $\mathrm{NaOH}$. Not sufficient removal of $\mathrm{NaOH}$ can lead to yellowing of the fabric during storage after drying. The aim of the bleaching experiments is to get insight in the performance of the (bio)-catalytic pre-treatment process under different bleaching conditions and concentrations of the bleaching agents.

Conventional pre-treatment consists of two or three sequential steps. But based on the result of the enzyme cocktail also one-bath pre-treatment will be explored. In the two-bath experiments the process is divided in different steps an enzymatic and a bleaching step. Between the subprocess steps the fabric will be rinsed. So here the bleaching step is performed in a beaker. The enzymatic treatment before bleaching is either performed in a beaker-glass to mimic continuous treatment or on a padder to mimic pad batch - hot bleach treatment.

\subsubsection{Experimental set up, materials and method}

One step pre-treatment

The set up of this experiment finds its origin in the results of the desizing and scouring step with the enzyme cocktail. There it has been found that the process conditions for this step are a low temperature $50^{\circ} \mathrm{C}$ and a process time of 15 minutes. The $\mathrm{pH}$ was set at 8 . In this experiment the option for one-bath bleaching by adding all pre-treatment agents in one bath has been explored. The fabric has been treated in a beaker-glass, which was placed in a Julaba SW 21 temperature controlled bath, shaken at $110 \mathrm{rpm}$. The LCR was $1: 100$. The incubation temperature was $50^{\circ} \mathrm{C}$ and the $\mathrm{pH}$ is during the first 10 minutes of treatment set at $\mathrm{pH} 8$. After 10 minutes of treatment

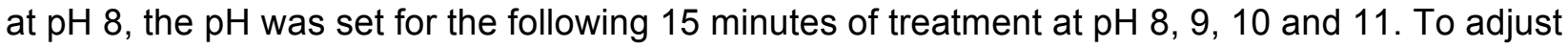
the $\mathrm{pH}$ of the bath $\mathrm{NaOH} 33 \%$ is used. The concentrations chemicals that have been used are:

$\begin{array}{lr}\text { - amylase } & 15 \mathrm{~g} / \mathrm{l} \\ \text { - } & 15 \mathrm{~g} / \mathrm{l} \\ \text { - } & \text { pectinase } \\ \text { surfactant } & 5 \mathrm{~g} / \mathrm{l} \\ & 20 \mathrm{~g} / \mathrm{l}\end{array}$

The enzyme solution is kept for 5 minutes at $50^{\circ} \mathrm{C}$. The samples are added to the solution, followed by the bleaching agents. The concentrations and bleaching agents are given below:

- $\mathrm{H}_{2} \mathrm{O}_{2} 30 \% \quad 10,0 \mathrm{ml} / \mathrm{l}$

- MnTACN 6,0 $\mathrm{\mu mol} / \mathrm{l}$

After 10 minutes incubation the $\mathrm{pH}$ of the pre-treatment liquor has been increased to the prescribed level with a $2 \mathrm{M} \mathrm{NaOH}$ solution. Every minute a sample is taken during the experiments. After the treatment the samples are rinsed at $50^{\circ} \mathrm{C}$ in distilled water, followed by a cold rinse. The fabric is dried on an acrylic plate overnight. 


\section{Two step pre-treatment}

The bleaching experiments have been carried out on percale. The fabric percale is, prior to bleaching, enzymatically pre-treated.

A beaker is filled with distilled water, which is buffered at $\mathrm{pH} 8$ with $50 \mu \mathrm{mol}$ Tris- $\mathrm{HCl}$ buffer. The solution was heated up to $50^{\circ} \mathrm{C}$ and thereafter placed in a Julaba SW 21 temperature controlled shaking bath (110 rpm). Next the enzyme-cocktail and surfactant are added to the beaker. The following concentrations chemicals have been used:

$\begin{array}{lrl}\text { - } & \text { amylase } & 15 \mathrm{~g} / \mathrm{l} \\ \text { - } & \text { cutinase } & 15 \mathrm{~g} / \mathrm{l} \\ \text { - } & \text { sectinase } & 5 \mathrm{~g} / \mathrm{l} \\ & 20 \mathrm{~g} / \mathrm{l}\end{array}$

The sample was added to the beaker after the addition of the chemicals and incubated during 15 minutes. All samples were percale and cut from the same lot. The size of the samples was 1 $\mathrm{dm}^{2}$. The weight of the fabric was about $130 \mathrm{~g} / \mathrm{m}^{2}$, resulting in a sample weight of $1,3 \mathrm{~g}$. The LCR used is 1:100. After enzymatic treatment the samples were rinsed two times in distilled water. The first rinse was at $50^{\circ} \mathrm{C}$ during 15 minutes, followed by a rinse at RT during 5 minutes. The fabric is dried on an acrylic plate overnight. The enzymatic pre-treatment step was followed by the bleaching step. In the bleaching step the following variables were explored: $\mathrm{pH}$, bleaching temperature, concentration of bleaching agents and bleaching time.

The bleaching variables and procedure is described as follows:

1. $\mathrm{pH}$

The $\mathrm{pH}$ was tested in the range varying from $\mathrm{pH} 9$ to $\mathrm{pH} 11$. For these experiments five beakers were filled with buffered solutions $(50 \mathrm{mM})$ at $\mathrm{pH} 9,10,10.2,10.5$, and 11 and heated up to $50^{\circ} \mathrm{C}$. Next the beakers were placed in a Julaba SW 21 shaking bath (110 rpm). The bleaching agents, $10 \mathrm{ml} / \mathrm{l} \mathrm{H}_{2} \mathrm{O}_{2} 35 \%$; 6 umol/L MnTACN; $1 \mathrm{ml} / \mathrm{l}$ Tanaterge Advance, have been added, immediately followed by the samples. The LCR is 1:100. The samples have been incubated during 15 minutes; where after the fabric was rinsed two times. The first rinse was at $50^{\circ} \mathrm{C}$ during 15 minutes, followed by a rinse at room temperature during 5 minutes. Finally the fabric was dried on acrylic plate overnight.

2. Bleaching temperature

The temperature was varied in the range $30-60^{\circ} \mathrm{C}$ in steps of $10^{\circ} \mathrm{C}$. Six beakers were prepared with a buffered solution at $\mathrm{pH} 10.2$ and heated up to the treatment temperature and consecutively placed in a Julaba SW 21 shaking bath (110rpm). After reaching the required temperature the bleaching agents were added, $10 \mathrm{ml} / / \mathrm{H}_{2} \mathrm{O}_{2} 35 \% ; 6 u \mathrm{~mol} / \mathrm{l} \mathrm{MnTACN}$ and 1 $\mathrm{ml} / \mathrm{l}$ Tanaterge Advance, immediately followed by the samples. The incubation time has been 15 minutes, where after the samples were rinsed two times. The first rinse was at $50^{\circ} \mathrm{C}$ during 15 minutes, followed by the second rinse at room temperature during 5 minutes. Next the fabric was dried on an acrylic plate overnight. 


\section{Concentration bleaching agents}

\section{Concentration MnTACN}

The concentration MnTACN is varied from $0-18 \mu \mathrm{mol} / \mathrm{l}$ in steps of $6 \mu \mathrm{mol} / \mathrm{l}$. Four beakers were prepared with a buffer solution at $\mathrm{pH} 10.2$ and heated up to $50^{\circ} \mathrm{C}$. Thereafter the beakers are placed in a Julaba SW 21 shaking bath $(110 \mathrm{rpm})$. Consecutively the bleaching agents were added, $10 \mathrm{ml} / / \mathrm{H}_{2} \mathrm{O}_{2} 35 \%$; $1 \mathrm{ml} / \mathrm{l}$ Tanaterge Advance and the required quantity MnTACN, immediately followed by the fabric. The fabric is incubated at $50^{\circ} \mathrm{C}$ during 15 minutes. After incubation the fabric was rinsed two times. The first rinse was at $50^{\circ} \mathrm{C}$, followed by a second rinse at room temperature during 5 minutes. After rinsing the fabric is dried on an acrylic plate overnight.

Concentration $\mathrm{H}_{2} \mathrm{O}_{2} 35 \%$

The concentration $\mathrm{H}_{2} \mathrm{O}_{2} 35 \%$ is varied from $0-15 \mathrm{ml} / \mathrm{l}$ in steps of $5 \mathrm{ml} / \mathrm{l}$. Four beakers were prepared with a buffer solution at $\mathrm{pH} 10.2$ and heated up to $50^{\circ} \mathrm{C}$. Thereafter the beakers were placed in a Julaba SW 21 shaking bath (110 rpm). Consecutively the bleaching agents were added, $6 \mu \mathrm{mol} / \mathrm{L}$ MnTACN, $1 \mathrm{ml} / \mathrm{l}$ Tanaterge Advance and the quantity $\mathrm{H}_{2} \mathrm{O}_{2} 35 \%$ as mentioned before, immediately followed by the fabric. The fabric was incubated at $50^{\circ} \mathrm{C}$ during 15 minutes. After incubation the fabric has been rinsed two times. The first rinse was at $50^{\circ} \mathrm{C}$, followed by a second rinse at room temperature during 5 minutes. After rinsing the fabric was dried on an acrylic plate overnight.

4. Bleaching time

The bleaching time was varied between 5 and 30 minutes. The effect of bleaching time has been evaluated for three types of bleach activators, which are listed below (the concentration per activator is mentioned between brackets):
- MnTACN
$(6 \mu \mathrm{mol} / \mathrm{l})$
- Tannex RL 1024A (10 ml/l)
- $\mathrm{NaOH} 33^{\circ} \mathrm{Be}$
$(10 \mathrm{ml} / \mathrm{l})$

The activator Tannex RL1024A is a mixture of a stabilizer and $\mathrm{NaOH}$. This product has been supplied by TanatexChenmicals.

The beakers were prepared with the buffered solution at $\mathrm{pH} 10.2$ and heated up to $50^{\circ} \mathrm{C}$ and placed in a Julaba SW 21 shaking bath (110rpm). The bleaching agents have been added to the solution, immediately followed by the samples. The concentration $\mathrm{H}_{2} \mathrm{O}_{2} 30 \%$ is $10 \mathrm{ml} / \mathrm{l}$ in distilled water. The samples have been incubated at $50^{\circ} \mathrm{C}$ during 15 minutes. The samples are rinsed two times after incubation. The first rinse was at $50^{\circ} \mathrm{C}$ during 15 minutes and the second rinse was at RT during 5 minutes. After rinsing the samples have been dried on an acrylic plate overnight.

\subsection{Results}

One step pre-treatment

The one step pre-treated samples have been evaluated for whiteness. The results are shown in figure 4.2. On the $\mathrm{Y}$-axis the whiteness is reported as a percentage of the target whiteness of 
$75^{\circ}$ Berger $\left(\mathrm{W}_{100}\right)$. The reported whiteness is relative to the whiteness of the greige fabric and the target whiteness. The aim was here to calculate the change of whiteness for the evaluation of the performance of the treatments. The relative whiteness (W) is calculated using the following equation:

$W=\left(1-\left(\frac{W_{100}-W_{S}}{W_{100}-W_{0}}\right)\right) x 100$

here $W_{100}$ is the target whiteness of the fabric. The measured whiteness of the fabric after treatment is $W_{S}$ and the measured whiteness of the greige fabric is $W_{0}$.

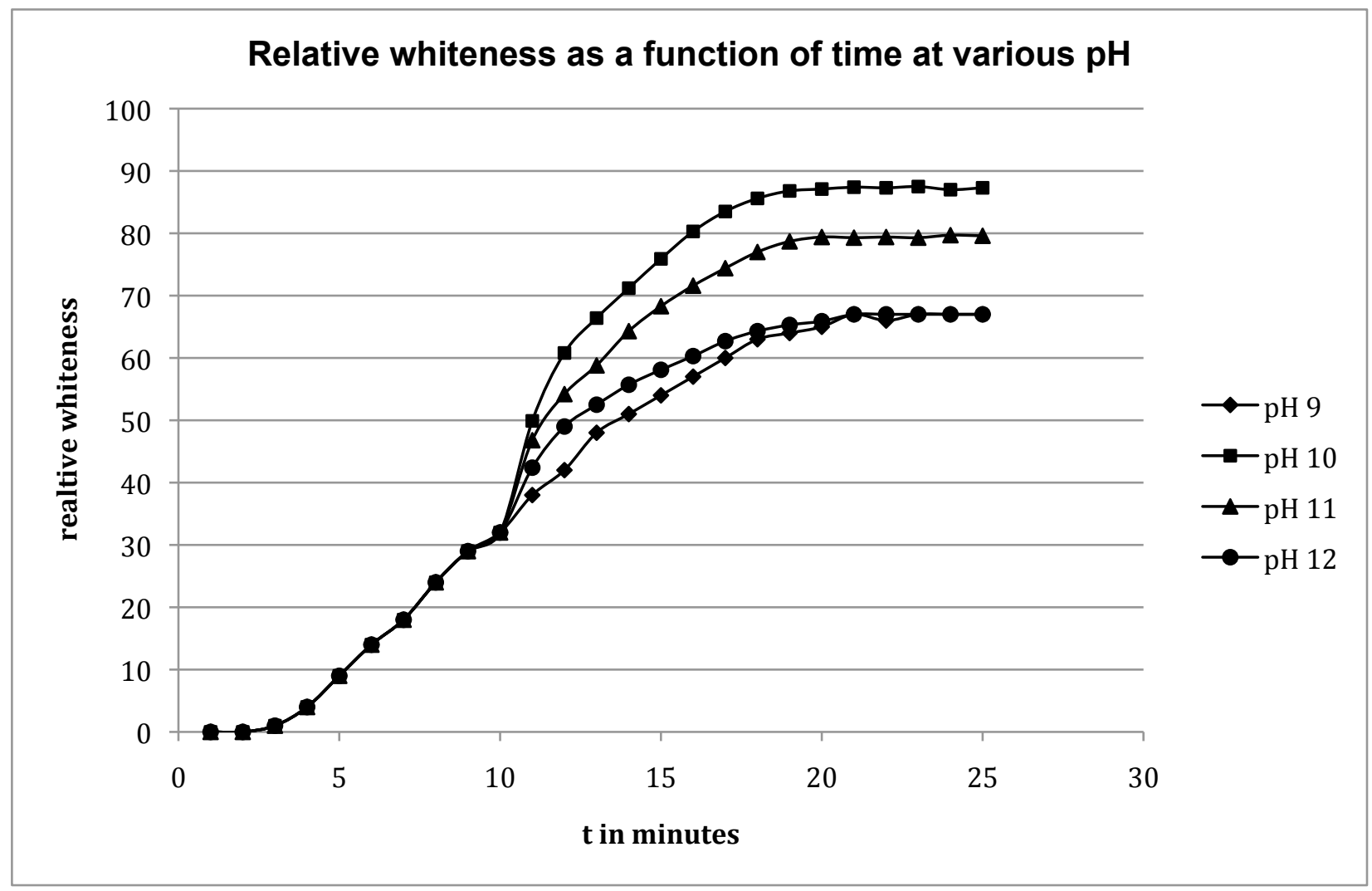

Figure 4.2: Whiteness after one-bath pre-treatment as a function of $\mathrm{pH}$

From the graph it can be concluded that the optimum $\mathrm{pH}$ for this experiment is $\mathrm{pH} 10$. This is in accordance to the findings of Topalovic (2007). At this $\mathrm{pH}$ the relative whiteness that has been realized is 87 . So here the principle is proven that one-bath pre-treatment of cotton with an enzyme cocktail and bleaching agents is possible under the prerequisite that $\mathrm{pH}$ adjustment after 10 minutes of treatment is possible. 
Two step pre-treatment

The samples have been evaluated after the last treatment for the following performance indicators:

- TEGEWA-value;

- hydrophilicity;

- whiteness as described earlier in this section;

- residual pectin.

The evaluation methods have been discussed in chapter 3 and chapter 4 .

$\mathrm{pH}$ variation

In table 4.1 the result is reported of the evaluation of percale after enzymatic pre-treatment and catalytic bleaching in a beaker. In the bleaching step of the pre-treatment process the $\mathrm{pH}$ has been varied to explore the influence of the $\mathrm{pH}$ on the performance of the treatment.

\begin{tabular}{|c|c|c|c|c|}
\hline $\mathbf{p H}$ & $\begin{array}{c}\text { TEGEWA- } \\
\text { value }\end{array}$ & Hydrophilicity in s & $\begin{array}{c}\text { Relative } \\
\text { Whiteness }\end{array}$ & $\begin{array}{c}\text { Residual pectin content } \\
\text { in } \%\end{array}$ \\
\hline 9 & 6 & 3 & 64 & 40 \\
\hline 10 & 7 & 2 & 77 & 35 \\
\hline 10.2 & 7 & 1 & 81 & 36 \\
\hline 10.5 & 7 & 1 & 80 & 35 \\
\hline 11 & 7 & 1 & 71 & 43 \\
\hline
\end{tabular}

Table 4.1: Result of bio-scouring and bleaching pre-treatment with $\mathrm{pH}$ variation

From these experiments it is clear that the optimum $\mathrm{pH}$ is 10.2 till 10.5. All performance indicators showed satisfactory results in this $\mathrm{pH}$ range. The decrease of whiteness outside the $\mathrm{pH}$ boundaries 10,2 to 10,5 requires careful $\mathrm{pH}$ control and adjustment during processing.

\section{Reaction temperature variation}

In table 4.2 the reaction temperature has been varied during the incubation of the bleaching process step. The reason for this experiment is to explore the influence of temperature variation on the performance of the treatment.

\begin{tabular}{|c|c|c|c|c|}
\hline $\begin{array}{c}\text { Temperature } \\
\text { in }{ }^{\circ} \mathbf{C}\end{array}$ & $\begin{array}{c}\text { TEGEWA } \\
\text {-value }\end{array}$ & Hydrophilicity in s & $\begin{array}{c}\text { Relative } \\
\text { Whiteness }\end{array}$ & $\begin{array}{c}\text { Residual pectin content } \\
\text { in \% }\end{array}$ \\
\hline 30 & 7 & 3 & 51 & 56 \\
\hline 40 & 7 & 3 & 65 & 52 \\
\hline 45 & 7 & 2 & 73 & 50 \\
\hline 50 & 7 & 1 & 80 & 38 \\
\hline 55 & 7 & 1 & 82 & 39 \\
\hline 60 & 7 & 1 & 82 & 35 \\
\hline
\end{tabular}

Table 4.2: Result of bio-scouring and bleaching pre-treatment with temperature variation 
From this table it can be concluded that the best performance is realized at a temperature above $50^{\circ} \mathrm{C}$. Striking is the clear improvement of the indicators starting from $50^{\circ} \mathrm{C}$. It is believed that this is caused by the enhanced decomposition of $\mathrm{H}_{2} \mathrm{O}_{2}$ from $50^{\circ} \mathrm{C}$. From table 2.3 and table 2.4 it was already clear that the TEGEWA-value under optimum treatment conditions during the first pre-treatment step is rated at 6 (Violet-scale). An extra step, in this case low temperature bleaching, improves the desizing rate with one point on the violet-scale. However the temperature variation in the bleaching process did not affect the desizing performance.

\section{Concentration variation}

In these experiments both MnTACN and $\mathrm{H}_{2} \mathrm{O}_{2}$ concentration have been varied to find the influence of concentration change of the bleaching agents in a combined enzymatic and catalytic pre-treatment process. The results are reported in table 4.3 for the variation of the MnTACN concentration and in table 4.4 for variations in the concentration $\mathrm{H}_{2} \mathrm{O}_{2}$.

\section{Variations of the concentration MnTACN}

\begin{tabular}{|c|c|c|c|c|}
\hline $\begin{array}{c}\text { [c] MnTACN } \\
\text { in } \boldsymbol{\mu \text { mol/L }}\end{array}$ & $\begin{array}{c}\text { TEGEWA- } \\
\text { value }\end{array}$ & Hydrophilicity in s & $\begin{array}{c}\text { Relative } \\
\text { Whiteness }\end{array}$ & $\begin{array}{c}\text { Residual pectin content } \\
\text { in \% }\end{array}$ \\
\hline 0 & 6 & 3 & 51 & 42 \\
\hline 6 & 7 & 1 & 80 & 42 \\
\hline 12 & 7 & 1 & 86 & 39 \\
\hline 18 & 7 & 1 & 85 & 38 \\
\hline
\end{tabular}

Table 4.3: Result of bio-scouring and bleaching pre-treatment with variation of the concentration MnTACN

This experiment clearly showed the role of the MnTACN catalyst. Without addition of the catalyst in the bleaching treatment a poor bleaching performance has been measured. This experiment shows also that the maximum whiteness is realized with the MnTACN concentration of 12 $\mu \mathrm{mol} / \mathrm{l}$. The concentration MnTACN that has been used influences hardly the TEGEWA-value. Here also it has been seen that some bleaching increases the TEGEWA-value with one point, but further no dependency of the concentration MnTACN has been measured for the desizing performance. Even addition of the catalyst in a system without $\mathrm{NaOH}$ boosts the bleaching performance. The addition of the MnTACN catalysts leads to improvement of the hydrophilicity of the fabric. No decrease of residual pectin content is realized at concentrations of 0 and 6 $\mu \mathrm{mol} / / \mathrm{MnTACN}$ catalyst, while further increased MnTACN concentration showed only a small improvement of the pectin removal. Here it is believed that the degradation of pectin in the bleaching bath is only satisfactory when high concentrations of $\mathrm{NaOH}$ have been used. 
Variation of the concentration $\mathrm{H}_{2} \mathrm{O}_{2}$

\begin{tabular}{|c|c|c|c|c|}
\hline $\begin{array}{c}\text { [c] } \mathbf{H}_{\mathbf{2}} \mathbf{O}_{\mathbf{2}} \text { in } \\
\mathbf{m l} / \mathbf{l}\end{array}$ & $\begin{array}{c}\text { TEGEWA- } \\
\text { value }\end{array}$ & Hydrophilicity in s & $\begin{array}{c}\text { Relative } \\
\text { Whiteness }\end{array}$ & $\begin{array}{c}\text { Residual pectin content } \\
\text { in \% }\end{array}$ \\
\hline 0 & 7 & 3 & 51 & 44 \\
\hline 5 & 7 & 5 & 65 & 44 \\
\hline 10 & 7 & 2 & 73 & 42 \\
\hline 15 & 7 & 1 & 80 & 38 \\
\hline
\end{tabular}

Table 4.4: Result of bio-scouring and catalytic bleaching pre-treatment with variation of the concentration $\mathrm{H}_{2} \mathrm{O}_{2}$

From this experiment it was obvious that the minimum concentration $\mathrm{H}_{2} \mathrm{O}_{2}$ that is required for acceptable whiteness values was $10 \mathrm{ml} / \mathrm{l}$. The increasing concentrations $\mathrm{H}_{2} \mathrm{O}_{2}$ also showed improved hydrophilicity. As it has been noticed before in this chapter TEGEWA-value was hardly influenced by oxidation. In that case a relation between improved whiteness and TEGEWA-value has to be evident. It might be that the extra 'rinsing' results in an improved desizing performance. Nevertheless it is concluded that at least $10 \mathrm{ml} / / \mathrm{H}_{2} \mathrm{O}_{2} 35 \%$ is required in this experimental set-up. In industrial pre-treatment processes higher concentrations $\mathrm{H}_{2} \mathrm{O}_{2}$ are used normally. The industrial concentrations depend on the type of process, fabric to be treated and required whiteness.

\section{Bleaching performance with different bleaching activators}

The bleaching time has been varied between 5 and 30 minutes. These reaction time variations have been carried out for the different bleaching activators that have been used under the same process conditions. The explored activators are MnTACN, Tannex RL $1024 \mathrm{~A}$ and $\mathrm{NaOH}$. The experiments are done at a reaction temperature of $50^{\circ} \mathrm{C}$. The concentration $\mathrm{H}_{2} \mathrm{O}_{2} 35 \%$ that has been used is $10 \mathrm{ml} / \mathrm{l}$.

Result of time variation with MnTACN catalyst

The performance of the MnTACN catalyst has been explored as a function of time. In table 4.5 the result is presented with MnTACN as catalyst and time variation in the range from 5 to 30 minutes at 5 minutes interval.

\begin{tabular}{|c|c|c|c|c|}
\hline Time & $\begin{array}{c}\text { TEGEWA- } \\
\text { value }\end{array}$ & Hydrophilicity in s & $\begin{array}{c}\text { Relative } \\
\text { Whiteness }\end{array}$ & $\begin{array}{c}\text { Residual pectin content } \\
\text { in \% }\end{array}$ \\
\hline 5 & 7 & 3 & 35 & 40 \\
\hline 10 & 7 & 1 & 41 & 42 \\
\hline 15 & 7 & 1 & 76 & 39 \\
\hline 20 & 7 & 1 & 80 & 38 \\
\hline 25 & 7 & 1 & 81 & 36 \\
\hline 30 & 8 & 1 & 78 & 35 \\
\hline
\end{tabular}

Table 4.5: Result of bio-scouring and catalytic bleaching with MnTACN with varied incubation time 
In this experiment the optimum bleaching time is 20 minutes to a satisfactory performance. A sharp increase in whiteness is noticed from an incubation time of 15 minutes. This leads to the conclusion that despite the activation of the decomposition of $\mathrm{H}_{2} \mathrm{O}_{2}$ with the MnTACN catalyst still 15 minutes or more is required for the bleaching process of the cotton fabric. Here again the independency of bleaching on the desizing performance has been confirmed. The residual pectin content is within the industrial standard of $40 \%$. The hydrophilicity of the samples is $1 \mathrm{~s}$ after 10 minutes of bleaching, which is generally accepted.

\section{Result of time variation with Tannex RL 1024 A bleach-activator}

In the experiments until now the decomposition of $\mathrm{H}_{2} \mathrm{O}_{2}$ has been activated by the MnTACNcatalyst. The catalyst has to be used under ambient temperature, preferably up or below $50^{\circ} \mathrm{C}$ due to its thermal instability. This maximum temperature can be realized when bleaching is done in aqueous environment, e.g. a jigger or a jet. However this type of discontinuous processing represents only a small part of global pre-treatment production capacity. In pad batch and full continuous bleaching equipment, which represents more than $70 \%$ of the global volume, the incubation during the bleaching-step is carried out in a steamer. In conventional steamers a temperature of $100^{\circ} \mathrm{C}$ and saturated air is necessary to avoid condensation spots on the pretreated fabric and to avoid drying of the fabric so no bleaching occurs. Bleaching steamers cannot be used for 'low-temperature' bleaching in saturated air without substantial additional investment. This equipment restriction caused that the MnTACN catalyst cannot be used in industrial conditions due to its thermal instability. For this reason it has been decided to test besides the MnTACN catalyst- other, well-known and commercial available bleaching activators in the new developed pre-treatment process.

In table 4.6 the results are reported of bio-scouring and bleaching at $50^{\circ} \mathrm{C}$ with Tannex RL 1024 A bleach activator in beaker-glass experiments. The concentrations bleaching agents are $10 \mathrm{ml} / \mathrm{l}$ $\mathrm{H}_{2} \mathrm{O}_{2} 35 \%$ in buffered distilled water.

\begin{tabular}{|c|c|c|c|c|}
\hline Time & $\begin{array}{c}\text { TEGEWA- } \\
\text { value }\end{array}$ & Hydrophilicity in s & $\begin{array}{c}\text { Relative } \\
\text { Whiteness }\end{array}$ & $\begin{array}{c}\text { Residual pectin content } \\
\text { in \% }\end{array}$ \\
\hline 5 & 7 & 2 & 42 & 41 \\
\hline 10 & 7 & 1 & 60 & 38 \\
\hline 15 & 7 & 1 & 81 & 36 \\
\hline 20 & 7 & 1 & 83 & 38 \\
\hline 25 & 8 & 1 & 82 & 37 \\
\hline 30 & 8 & 1 & 83 & 36 \\
\hline
\end{tabular}

Table 4.6: Result of bio-scouring and bleaching with Tannex RL 1024 A with varied incubation time

When the performance of pre-treatment and bleaching with MnTACN and Tannex RL 1024 has been compared it is clear that Tannex RL 1024 A gives comparable TEGEWA-value and hydrophilicity-value as previous observations. Tannex RL $1024 \mathrm{~A}$ is a bleaching auxiliary with good sequestering and stabilizing properties. A small concentration $\mathrm{NaOH}$ has been added to Tannex RL $1024 \mathrm{~A}$ to initiate the activation of the decomposition of $\mathrm{H}_{2} \mathrm{O}_{2}$. The realized relative whiteness in this experiment indicates that the quantity $\mathrm{NaOH}$ as bleach-activator can be 
reduced after bio-scouring because in this case about $10 \%$ of the amount $\mathrm{NaOH}$ has been used compared to the previous experiments. It is believed that the whiteness is a function of the gradually decomposition of $\mathrm{H}_{2} \mathrm{O}_{2}$ that is controlled by the stabilizing properties of the applied bleaching agent.

The whiteness has been improved with Tannex RL 1024 A as bleach-activator, when compared with the manganese catalyst. Especially in the time range around 15 minutes it has been noticed that the performance of Tannex RL $1024 \mathrm{~A}$ is better.

The third bleach activator in these experiments is $\mathrm{NaOH}$, which is used in high concentrations in the bleaching step in conventional pre-treatment processes. $\mathrm{NaOH}$ has been explored because it is the most used bleach activator until now and this experiment will be used as benchmark for the other bleach-activators. The results are summarized in table 4.7.

\begin{tabular}{|c|c|c|c|c|}
\hline Time & $\begin{array}{c}\text { TEGEWA- } \\
\text { value }\end{array}$ & Hydrophilicity in s & $\begin{array}{c}\text { Relative } \\
\text { Whiteness }\end{array}$ & $\begin{array}{c}\text { Residual pectin content } \\
\text { in \% }\end{array}$ \\
\hline 5 & 7 & 2 & 45 & 41 \\
\hline 10 & 7 & 2 & 65 & 41 \\
\hline 15 & 7 & 1 & 78 & 38 \\
\hline 20 & 8 & 1 & 78 & 39 \\
\hline 25 & 8 & 1 & 81 & 39 \\
\hline 30 & 8 & 1 & 80 & 39 \\
\hline
\end{tabular}

Table 4.7: Result of bio-scouring and bleaching with $\mathrm{NaOH}$ with varied incubation time

Here it can be seen that the result of $\mathrm{NaOH}$ as bleaching activator, when compared to MnTACN is similar in terms of whiteness and residual pectin content. The 'stabilizer' Tannex RL 1024A however showed the best result in terms of whiteness, hydrophilicity and residual pectin content. Until now it can be concluded that for bleaching -under the experimental conditions- the MnTACN activator has no advantages in terms of performance over $\mathrm{NaOH}$ or Tannex RL 1024A as bleaching activator. Despite these draw back's for the manganese catalyst it is likely that the bleaching performance with this catalyst, compared to $\mathrm{NaOH}$ or to Tannex RL 1024 A activated decomposition of $\mathrm{H}_{2} \mathrm{O}_{2}$, will be better.

It is known that the use of high concentrations $\mathrm{NaOH}$ makes rinsing of the fabric more difficult, as $\mathrm{NaOH}$ acts rather 'stickey' to the fabric and that therefore high temperature and large volumes of rinsing water are necessary for sufficient $\mathrm{NaOH}$ removal [Benninger, private communication, Rouette (ed.) 2001]. This disadvantage is less evident in these experiments as an LCR of 1:100 is used. In rinsing processes in industry a LCR of 1:5 till 1:10 is normally used. The evaluation of residual $\mathrm{H}_{2} \mathrm{O}_{2}$ has been measured after bleaching by titration with permanganate. It showed that $\mathrm{H}_{2} \mathrm{O}_{2}$ is gradually decomposed during the bleaching process and showed a comparable decomposition of peroxide when $\mathrm{NaOH}$ and Tannex $1024 \mathrm{~A}$ as bleach activator was used. The residual $\mathrm{H}_{2} \mathrm{O}_{2}$ content however when MnTACN as bleach activator was used decreased much slower and at the end of the process more residual peroxide was present in the bleaching bath. It is assumed that this is caused by the thermal instability of the catalyst. 


\subsection{Conclusion}

The beaker glass experiments showed that the pre-treatment consisting of enzymatic desizing and scouring, followed by catalytic bleaching delivered a product that meets the required levels of desizing and hydrophilicity. In section 4.5.1 it was seen that in one bath treatment the same whiteness can be realized as in two-step treatment with a rinse between the first and the second pre-treatment step. However in this process it has been concluded that the $\mathrm{pH}$ has to be increased from $\mathrm{pH} 8$ that has been applied during the first 10 minutes in the enzymatic step has to be increased to $\mathrm{pH} 10$. At this alkaline condition the best bleaching performance has been realized. The hydrophilicity and residual pectin content of the fabric are within industrial acceptable values.

In the catalytic bleaching step it has been concluded that the best performance was realized in the $\mathrm{pH}$ range from 10.2 to 10.5 . This narrow range is no technical restriction as the bleaching liquor can be buffered with commercially available textile auxiliaries. Most peroxide stabilizers have buffering capacities in this afore mentioned range. The concentrations of the bleaching agents that have been used in these experiments are in the same order of magnitude as the concentrations used in industry. The experiments showed that the optimum temperature for this bleaching experiments is $50^{\circ} \mathrm{C}$. Below this temperature poor whiteness was realized, and above $50^{\circ} \mathrm{C}$ a plateau for whiteness has been observed. This plateau can form a major draw back for industrial implementation. This is caused by the fact that capital investment is necessary to realize a saturated humidity at $50^{\circ} \mathrm{C}$ in existing steamers, without running the risk of water spots on the fabric. The obtained results with low alkali bleaching indicate that desizing and bioscouring in combination with low alkali bleaching might be an alternative for catalytic bleaching without adjustments to the bleaching steamer. Hardly any bleaching occurs during the first 15 minutes of the process. So without the use of a steamer in catalytic bleaching at $50^{\circ} \mathrm{C}$ the reaction time of this process is too short. Other work confirms these findings [Topalovic, 2007]. To overcome the possible drawbacks of the catalytic bleaching process other bleaching activators have been evaluated and compared with MnTACN catalytic treated fabric. Besides the long reaction time under the applied conditions all three activators show good bleaching performance. The desizing and pectin removal are within the industrial required values. The final whiteness was slightly better when the Tannex RL 1024 A activator was used. It was surprising that the Tannex RL 1024 A- bleaching stabilizer, that contains a small concentration sodiumhydroxide, renders a comparable whiteness to the $\mathrm{NaOH}$ activated bleach process. The low quantity of $\mathrm{NaOH}$ that is required for bleaching after the enzymatic treatment might be explained with the fact that the cotton wax and pectin in the primary wall of cotton have been degraded in the enzymatic treatment step and not in the bleaching step of the pre-treatment process. Consequence of the use of low concentrations $\mathrm{NaOH}$ is that it is possible to decrease the rinsing temperature and probably the consumption of rinsing water after bleaching.

So it has been decided to continue with enzymatic desizing and scouring in combination with $\mathrm{NaOH}$ or Tannex RL 1024 A activated bleaching at $100^{\circ} \mathrm{C}$ as MnTACN is not stable above $50^{\circ} \mathrm{C}$. During the experiments it was clear that in this process a major reduction of rinsing temperature, from $100^{\circ} \mathrm{C}$ to $50^{\circ} \mathrm{C}$ or lower after bleaching is possible without capital investment. 
In industrial experiments also mechanical energy will be supplied to the fabric. It is expected that this phenomenon will improve the pre-treatment performance. During industrial experiments the process conditions and concentrations chemicals used, will be optimized. To realize the objectives of water and energy reduction it is important to avoid or to reduce the use of $\mathrm{NaOH}$ to a minimum as bleaching activator. 


\section{References}

Benninger, private communications, 2005, 2010

Hage, R. and A. Lienke, "Applications of transition-metal catalysts to textile and wood-pulp bleaching”, Angewandte Chemie Int. Ed., Volume 45, p206-222, 2006

Hebeish A., M. Hashem, N. Shaker, M. Ramadan and B. El-Sadek, "New development for combined bioscouring and bleaching of cotton based fabrics", Carbohydrate Polymers, Volume 78, p 961 - 972, 2009

Opwis K., D. Knittel, A. Kele and E. Schollmeyer, "Enzymatic recycling of starch-containing desizing liquors", Starch/Staerke, Volume 51, P 348 - 353, 1999

Rouette, H.K., "Encyclopedia of Textile Finishing", ISBN 3-540-65031-8, Springer Verlag Berlin/Germany, 2001

Rupp, J., "Gentle power bleach" Brochure from Huntsman/Genencor, March/April 2009

Topalovic, T., "Catalytic bleaching of cotton: Molecular and macroscopic aspects", ISBN 90-3652454-7, Thesis University of Twente, 2007

Tzanov T., S.A. Costa, G.M. Guebitz and A. Cavaco-Paulo, "Hydrogen peroxidase generation with immobilized glucose-oxidase for textile bleaching", Journal of Biotechnology, Volume $90, p$ $87-94,2002$

Wieghard, K., U. Bossek, B. Nuber, J. Weiss. J. Bonvoisin, M. Corbella, S.E. Vitol and J.J. Girrerd, 'Synthesis, Crystal Structures, Reactivity, and Magnetochemistry of a Series of Binuclear Complexes of Manganese (II), -(III) and -(IV) of Biological Relevance', Journal of American Chemists Society, 110, 7398, 1988 

Knowledge of mass transfer is important to understand wet textile processes. This importance increases with the increasing molecular size of the chemicals that are used in wet processing.

To obtain insight in the role of mechanical energy a squeezing and mass transfer models will be introduced. These models are qualitatively validated with enzymatic release experiments on labscale. Finally the adsorption limitation of enzymes in the capillaries of the yarn is introduced, leading to insights in the importance of refreshment of the enzymatic volume in the capillaries of textile substrates. 


\subsection{Introduction}

In chapter two and three it is reported that bio-catalytic pre-treatment of cotton is possible under ambient conditions on lab- and pilot-scale processes. From these results it seems quite simple to upscale bio-catalytic treatment to industrial scale and replace the conventional chemicals by enzymes. In practice however it has been found that simple up scaling often results in a poor performance and thus leading to reject modern bio-catalytic processing [Bouwhuis et al. 2009]. The main difference between conventional and bio-catalytic pre-treatment, from a processdevelopment point of view, is the molecular size of the chemicals that are used and the substantial reduction of temperature. Moreover the kinetics of enzymatic reactions is more complex than in the case of traditional chemistry. This complex diffusion control of the transport of enzymes inside the pores of a fabric leads to a suboptimal adsorption of enzymes at the capillary surface. Therefore the key for a good performance using enzymes in textile treatment processes is an optimal mechanical action to prevent diffusion control. It could be argues that the enzyme amylase is successfully applied in the textile industry for the desizing process, without transport limitations, but the reason for this is that the size is present only at the outer surface of the weft yarns and these surfaces can easily be accessed by enzymes without a limiting transfer process between the fibres of the yarns.

There has been a great deal of research on the application of enzymes in wet textile processes. However, work in which the role of mechanical energy is also included is rather rare. There are some data on the role of mechanical energy in wet textile processes, but these are mainly related to fabric wash processes [Donck, van der et al 1998, Warmoeskerken \& Boom, 1999]. Lenting and Warmoeskerken (2001) discussed the role of mechanical shear in enzymatic textile treatment. This work was focussed on the removal fibril pills during the treatment of cotton fabric with cellulase. Agrawal et al. (2008) were the first to show unambiguously that there is strong synergistic relation between the performance of enzymes in wet textile processes and the mechanical energy applied. They also showed that the mechanical action could be delivered by ultra sound resulting in a very effective and efficient enzymatic treatment process. (Agrawal et al. 2007). Data on the suboptimal adsorption of enzymes at the surfaces of the textile capillaries are not available. In this chapter, the phenomena mentioned are discussed and models that describe them are presented.

\subsection{Current processes for the pre-treatment of cotton}

In cotton pre-treatment different installed base and processing are possible to realize sufficient desized, scoured and bleached fabric for consecutive treatments as dyeing, printing or finishing. The process steps for pre-treatment of cotton are:

1. desizing: removal of starch from the warp yarns;

2. scouring: removal of the waxes and pectin for sufficient hydrophilicity;

3. bleaching: decolourization of the natural 'grey' colour of cotton.

If possible one or more process steps are combined. 
For pre-treatment of cotton different types of processes are available:

1. Full-continuous

This process is carried out on two types of installed base in open with or in rope from.

In open width the fabric is successively impregnated with processing agents on an impregnation unit. This unit consists of rollers that guide the fabric in and out the bulk. During the impregnation the fabric is at least one time squeezed. After impregnation the fabric is incubated in a steamer, where the fabric is guided over rollers. In the steamer the chemical reaction takes place. After incubation the fabric is rinsed in in washing compartments. A washing compartment consists of rollers to guide the fabric in and out the bulk to rinse out the impurities. The process steps desizing, scouring and bleaching are treated according the same pattern of impregnation, incubation and rinsing. Per process-step different impregnation, incubation and washing units can be distinguished depending on time, temperature and mechanical energy necessary for the desired result. A complete installed base for continuous pre-treatment of cotton is schematically drawn in figure 2.6. A detailed impregnation and rinsing compartment are shown in figure 5.1 and a steamer is shown in figure 5.2 [Benninger, 2010].

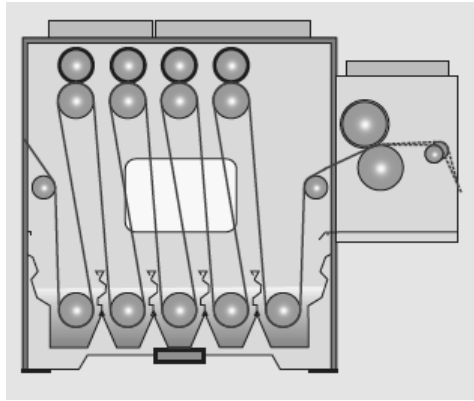

Figure 5.1: Impregnation and rinsing compartment
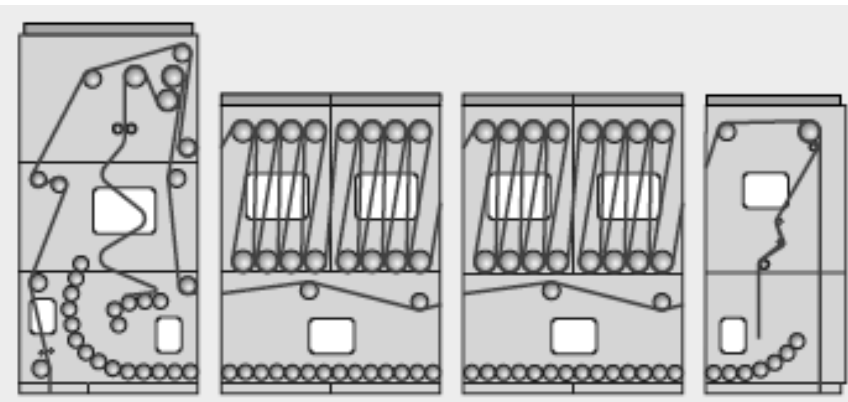

Figure 5.2: Steamer with roller bed (incubation unit).

In rope from the same pattern of impregnation, incubation and rinsing is followed. Impregnation is done on a rope impregnation unit, followed by incubation in J-boxes. A J-box is a large upright J-shaped vessel, which serves as a storage chamber, for continuous processing of textiles in rope form to provide the necessary incubation time [Rouette (Ed.), 2001]. Rinsing also takes place in J-boxes, which are alternated with rope-squeezers. Characteristic for this process is the kneading of the fabric by filling the J-boxes completely with fabric in rope from and pushing the fabric through the J-box. The latter is only possible when large amounts of fabric are in the J-box and therewith long impregnation, incubation and rinsing time is achieved.

The mechanical energy supplied by continuous full width treatment is more intensive compared to treatment in rope form. Consequence is longer process time on installed base for rope treatment. 


\section{Pad batch-hot bleach}

Pad batch-hot bleach is an open width treatment. The fabric is impregnated in an impregnation compartment in which the fabric is guided over rollers in and out the bulk. After impregnation the fabric is rolled on an A-frame and incubated for several hours (8 - 24 hours). After incubation the fabric is rinsed in washing compartments and consecutive impregnated with bleaching agents and incubated in a steamer. For impregnation high concentrations (>100\% pick-up o.w.f.) of bleaching agents are added on the fabric. After incubation the fabric is rinsed in washing compartments.

\section{Discontinuous}

In a discontinuous installed base the fabric is guided into the machine and transported/moved in the same compartment. Different types of discontinuous installed base are e.g. jigger, jet and winch.

On a jigger the fabric is moved from one roller to the opposite roller (visa versa) via the treatment bath, which contains the treatment agents. In a jet the fabric is guided in a rope form in a J-box. The rope is made endless and guided out of the bulk through a pipe to the loading point of the J-box. In the J-box the fabric is kneaded and pushed forward for the next tour. A winch is very similar to a jet. The main difference is the transport of the endless fabric in rope form. The fabric is stored in the bulk and taken out of the bulk by the winch. After passing the oval winch the fabric is again laid down in the bulk to be pushed and kneaded again.

The selection of the different installed base for processing is often related to the construction of the fabric, production volumes, batch-size and operating window.

The mechanical energy in the different process forms is represented in table 5.1.

\begin{tabular}{|c|c|c|c|c|c|}
\hline \multirow[t]{2}{*}{ Process } & \multicolumn{3}{|c|}{$\begin{array}{r}\text { Process step } \\
\end{array}$} & \multirow[b]{2}{*}{ process time } & \multirow[b]{2}{*}{ [c] } \\
\hline & impregnation & incubation & rinsing & & \\
\hline \multicolumn{6}{|c|}{ Full continuous/open width form } \\
\hline - desizing & $\mathrm{rrs}$ & $\mathrm{rr}$ & rr ss & $\mathrm{t}$ & $\mathrm{CC}$ \\
\hline - scouring & $\operatorname{rrs}$ & $\mathrm{rr}$ & rr ss & $\mathrm{t}$ & $\mathrm{CC}$ \\
\hline - bleaching & rs & $\mathrm{rr}$ & rr ss & $\mathrm{t}$ & $\mathrm{CC}$ \\
\hline \multicolumn{6}{|c|}{ Full continuous/rope form } \\
\hline - desizing & kk ss & $\mathrm{kk}$ & kk ss & $\mathrm{tt}$ & C \\
\hline - scouring & kk ss & kk & kk ss & $\mathrm{tt}$ & C \\
\hline - bleaching & kk ss & kk & kk ss & $\mathrm{tt}$ & $\mathrm{C}$ \\
\hline \multicolumn{6}{|c|}{ Pad batch-hot bleach } \\
\hline - desizing & $\operatorname{rrs}$ & $\mathrm{n}$ & rr ss & $\mathrm{ttt}$ & $\mathrm{C}$ \\
\hline - bleaching & rr ss & $\mathrm{rr}$ & rr ss & $t$ & CCC \\
\hline \multicolumn{6}{|c|}{ Discontinuous } \\
\hline - jigger & $r$ & & & $\mathrm{ttt}$ & $\mathrm{C}$ \\
\hline - jet & $\mathrm{k}$ & & & $\mathrm{ttt}$ & $\mathrm{C}$ \\
\hline - winch & $\mathrm{k}$ & & & $\mathrm{ttt}$ & $\mathrm{C}$ \\
\hline
\end{tabular}

Table 5.1: Qualitative survey on mechanical energy per installed base and process step 
The symbols used in the table are:

$r$ : Mechanical energy due to rollers

rr: Mechanical energy due to rollers, at least two times bending in opposite direction

s: $\quad$ Squeezing, one time

ss: $\quad$ Squeezing, at least two times

$\mathrm{k}$ : Kneading of the fabric

kk: Intensive kneading

$\mathrm{t}$ : Time consumption; increasing number of t's relates increasing time consumption

c: Concentration chemicals used; increasing number of c's relates increasing chemical concentration

$\mathrm{n}$ : No mechanical energy

From table 2.1 it is clear that there are many possible options for the pre-treatment of fabrics and each option has its characteristic way to add mechanical energy to the process. Since mechanical energy is a key-factor in the performance of enzymes it is to be expected that enzymes will perform differently on the different systems presented in the table. It is evident that there will be a strong relationship between the amount of mechanical energy applied to the process and the time required to achieve a good enzymatic performance. Therefore a profound understanding of the mechanical energy is these systems and its effect on enzymatic processes is a prerequisite for a successful introduction of enzymes in the textile industry.

\subsection{Mass transfer limitations in textiles}

To understand the role of mechanical energy in enzymatic textile processes knowledge of mass transfer phenomena in these systems is necessary [Nierstrasz \& Warmoeskerken, 2003]. Textile is a material with a dual porosity; pores between the yarns and pores between the fibres (figure 5.3).

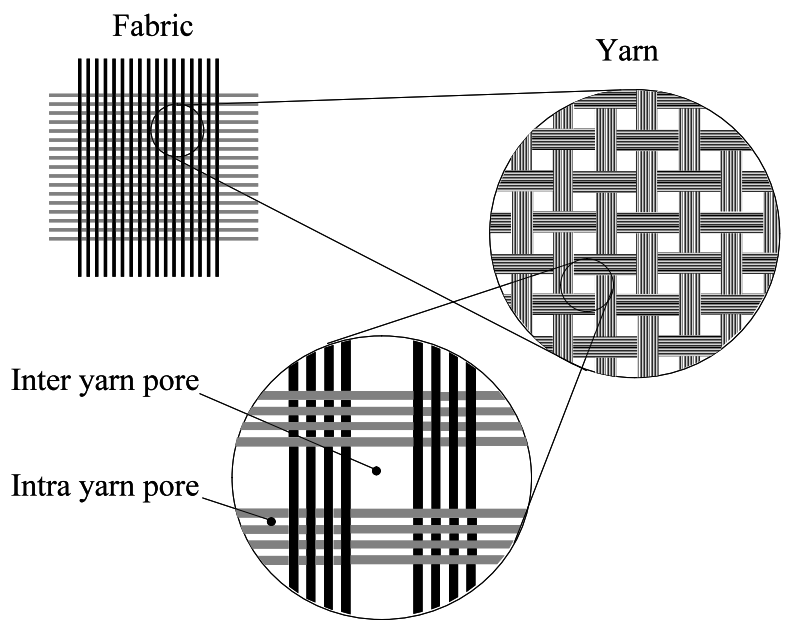

Figure 5.3: Schematic representation of the structure of a woven textile material showing dual porosity; intra yarns and inter yarn pores [Nierstrasz \& Warmoeskerken, 2003] 
The pores between the yarns are called the inter yarn pores and the pores between the fibres are called the intra yarn pores. For a woven cotton fabric the inter yarns pores have a diameter in the order of $50 \mu \mathrm{m}$ and the intra yarns pores have a diameter in the order of $2 \mu \mathrm{m}$. This difference makes that when water flows through the fabric, it will flow through the inter yarn pores rather than through the intra yarn pores. The smaller the diameter, the higher the flow resistance will be. Therefore there will be a great part of the fabric where there is no flow at all. This is visualised in a model as shown in figure 5.4 [Warmoeskerken \& Boom, 1999]. This figure shows the cross section of a yarn and its fibres. The bulk of the water flows through the inter yarns pores. Dependent on the water flow intensity there will be some flow of water between the fibres as indicated in the figure. Based on that two zones in the yarn are defined: a stagnant core and a convective shell. In the stagnant core there is no flow at all and in the convective shell the flow penetrates to some extend. It is clear that mass transfer in the stagnant zone is completely determined by molecular diffusion, while in the convective shell mass transfer is controlled by convection. Now suppose a yarn that is completely wetted, so all the inter and intra yarn pores are filled with water and this yarn is put into a still standing enzyme solution so all the liquid in the yarn is stagnant. The enzyme solution will then start to diffuse into the yarn.

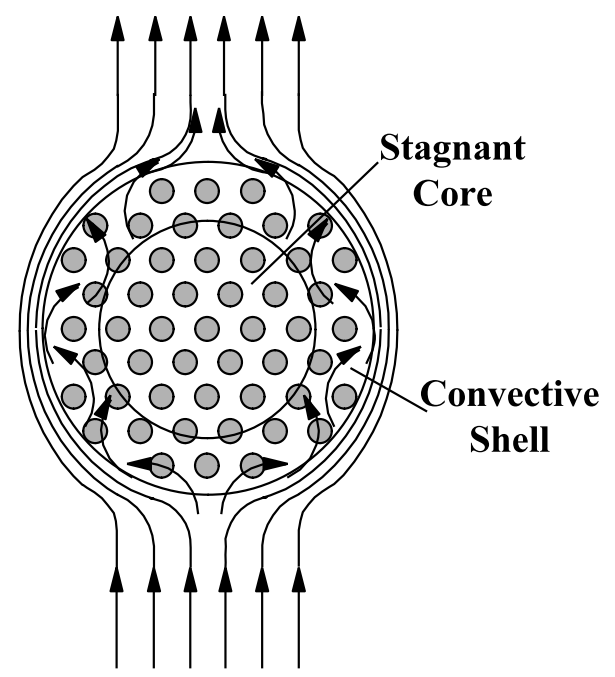

Figure 5.4: Schematic representation of the liquid flow around and through the yarn. The dots represent the fibres

This process is described by the diffusion equation of Fick [Nierstrasz \& Warmoeskerken, 2003]]:

$$
\frac{\partial C_{E, Y}}{\partial t}=\frac{D}{r_{Y}} \frac{\partial}{\partial r}\left(r_{Y} \frac{\partial C_{E, Y}}{\partial r_{Y}}\right)
$$

in which $C_{E, Y}$ is the enzyme concentration in the yarn in $\mathrm{kg} / \mathrm{m}^{3}, r_{Y}$ is the yarn radius in $\mathrm{m}, D$ is the diffusion coefficient of the enzymes in $\mathrm{m}^{2} / \mathrm{s}$ and $\mathrm{t}$ is the time in $\mathrm{s}$. This equation describes only the diffusion process in the radial direction of the yarn. This equation can be solved for 
different initial and boundary conditions. Here we consider the situation in which the enzymes diffuse from a bulk solution into the yarn and we assume that the enzyme concentration in the bulk remains constant, because the volume of the bulk is much bigger than the volume of the intra yarn pores. This means that the concentration of the enzymes at the outer surface of the yarn is constant and equal to the bulk concentration. The second assumption is that at the start of the diffusion process no enzymes are present in the yarn. The solution of equation (5.1) is often graphically given as in figure 5.5 .

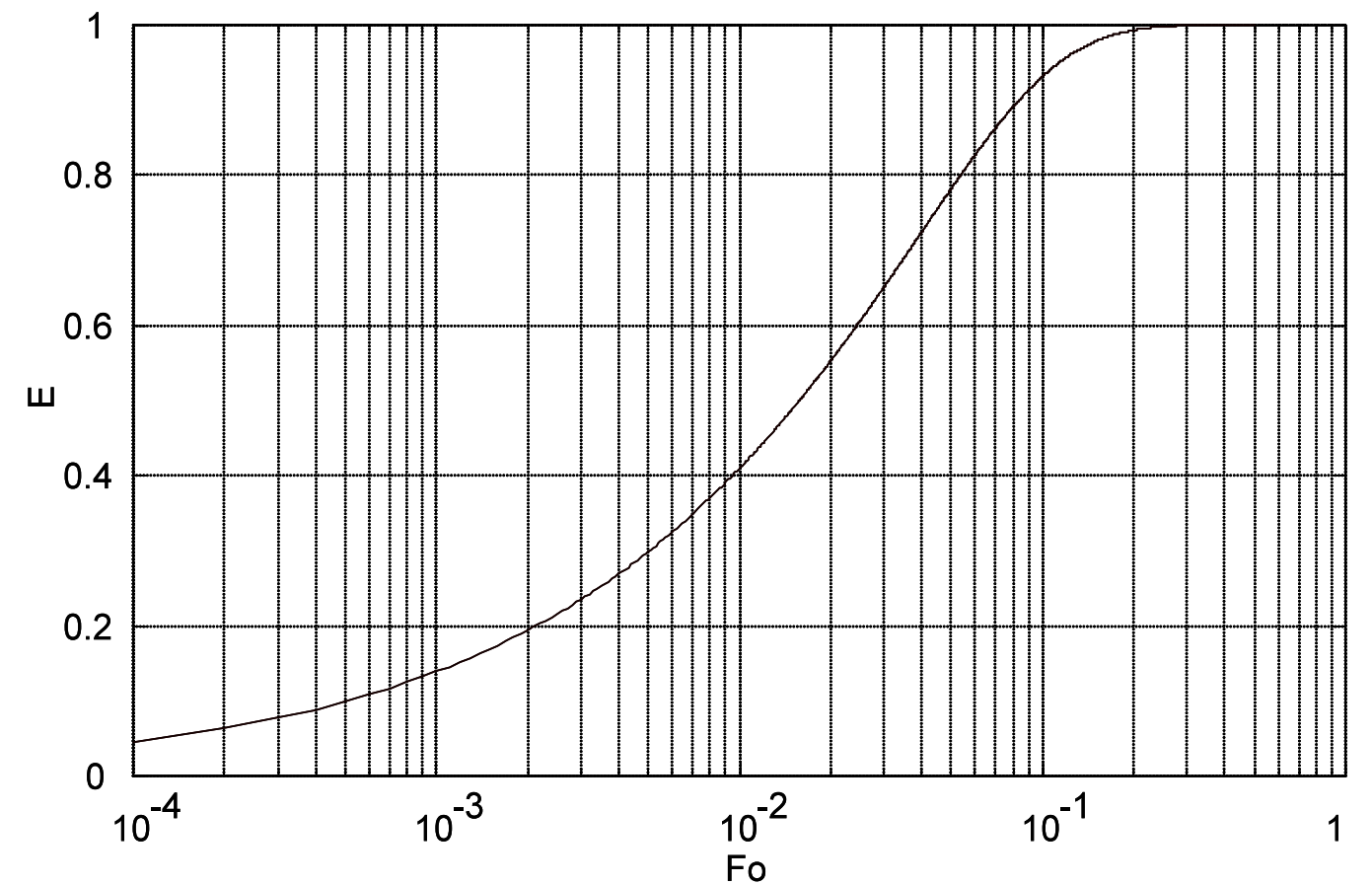

Figure 5.5: Solution of the diffusion problem (equation 5.1)

The variable $\mathrm{E}$ on the vertical axis is the dimensionless mean concentration in the yarn:

$$
E=1-\frac{C_{E, b}-\bar{C}_{E, Y}}{C_{E, b}-\bar{C}_{E, Y, 0}}
$$

in which $C_{E, b}$ is the enzyme concentration in the enzyme solution in $\mathrm{kg} / \mathrm{m}^{3}, \bar{C}_{E, Y}$ is the mean enzyme concentration in the yarn in $\mathrm{kg} / \mathrm{m}^{3}$. The variable on the horizontal axis is the Fourier number and is a dimensionless expression for the diffusion in time:

$F_{O}=\frac{D t}{d_{Y}^{2}}$

in which $d_{Y}$ is the yarn diameter in $\mathrm{m}$. 
Now the diffusion time of enzymes into the yarn can be calculated. Suppose that the diameter of the yarn is $0,5 \mathrm{~mm}$ and that the diffusion coefficient in the yarn is $D=10^{-11} \mathrm{~m}^{2} / \mathrm{s}$ based on an enzyme molecule of $25 \mathrm{kDa}$ and an intra yarn porosity of 0,4 [Nierstrasz \& Warmoeskerken, 2003]. If $E=0,9$ i.e. the mean enzyme concentration in the yarn is $90 \%$ of the enzyme concentration in the solution, assuming that the initial enzyme concentration in the yarn is zero, $\bar{C}_{E, Y, 0}=0$ ). From figure 5.5 it follows that $\mathrm{Fo} \approx 0,1$. From this value and equation 5.3 , a diffusion time of $2.500 \mathrm{~s}$ is calculated. This means that in this example a diffusion time of approximately 40 minutes is required to achieve a mean enzyme concentration in the intra yarn pores which is $90 \%$ of the final value. It is clear that this is too long for normal treatment processes. If the calculation is repeated for small molecules such as $\mathrm{NaOH}$, the diffusion time is in the order of $25 \mathrm{~s}$, which is much shorter than the value for big enzyme molecules. The mass transfer time for enzymes can only be reduced by applying mechanical energy, that induces flow within the intra yarn pore, consequently resulting into a smaller stagnant core, and thus more convective transfer. The way to achieve this is squeezing the fabric to force water to flow through the intrayarn capillaries. This can be achieved when the fabric is running over rollers or passing between squeezing rollers. The mechanical energy delivered by these systems and their effect on mass transfer inside the textile is unknown. To enable the squeezing action in textile treatment systems, a model is developed that relates the performance of wet textile equipment to a squeezing factor $\alpha$.

\subsection{The squeezing model}

As stated the mechanical energy in textile treatment equipment is aimed at deforming the porous fabric to create velocities in the pores of the textile. Figure 5.4 shows the yarn model with the stagnant core and convective shell. In the stagnant core the mass transfer is fully controlled by diffusion, while in the convective shell this is based on convection, i.e. the flow of the liquid. A model that describes this system will be derived here. In this model a squeezing factor $\alpha$ is incorporated, that expresses the ratio between the stagnant and the convective regions. To make the model less complicated the fabric is modelled as a porous slab with a stagnant centre and two convective outer layers (figure 5.6).

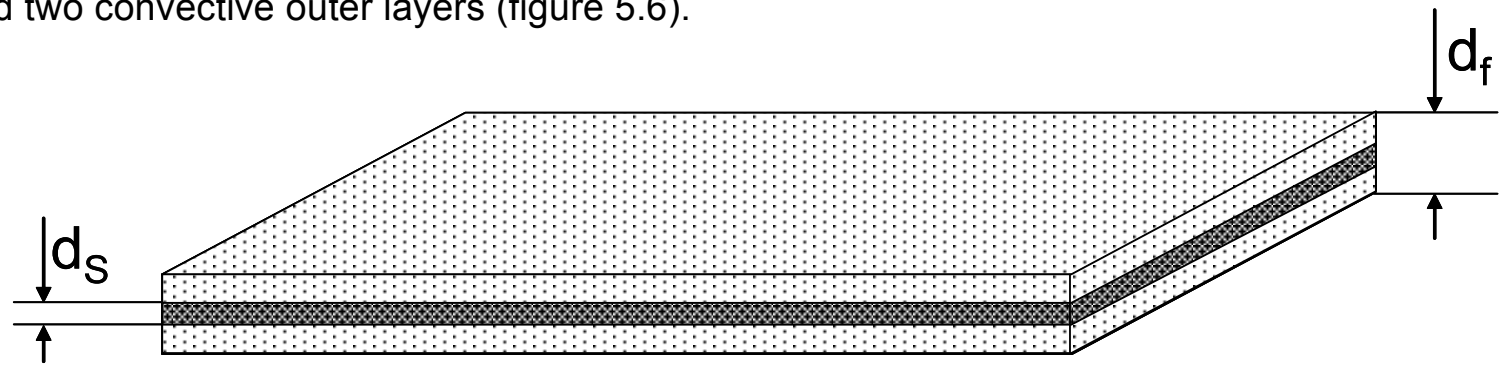

Figure 5.6: Schematic drawing of a textile modelled as a porous slab

In this figure $d_{f, S}$ is the thickness of the stagnant middle layer and $d_{f}$ is the thickness of the fabric. So the thickness of the convective layers, $d_{f, C}$ is:

$d_{f, C}=d_{f}-d_{f, S}$ 
The squeezing factor $\alpha$ is now defined as:

$$
\alpha=\frac{\text { Volume_of_the_convective_layers_in_the_fabric }}{\text { Total_volume_of_the_fabric }}=\frac{V_{f, C}}{V_{f}}
$$

When the surface area of the textile is $\mathrm{A}^{2}$ than for $\alpha$ can be written:

$$
\alpha=\frac{A d_{f, C}}{A d_{f}}=\frac{d_{f, C}}{d_{f}}=1-\frac{d_{f, S}}{d_{f}}
$$

If $\alpha$ equals zero, it means that $d_{f, S}$ equals $d_{f}$ what is the case when there is no flow at all, so the liquid in the total volume of the fabric is stagnant. If $\alpha$ equals 1 it means that $d_{f, S}$ equals 0 what is the case if the water flows in all the pores of the fabric. When the flow in the fabric is related to deformation it is clear that $\alpha=1$, all pores are deformed and maximum deformation effect of the mechanical energy is realized and flow in all the pores is realized. If $\alpha=0$, no pores are deformed, no deformation effect of the mechanical energy is realized and thus no flow in the pores occurs. It must be noted here that the value of the squeezing parameter $\alpha$ must be seen as mean time value. So when the fabric is going through a padding bath, the squeezing factor of this system is a mean value taken from the point where the fabric enters the bath until the point where the fabric leaves the bath. The $\alpha$ factor of the bath is an indication for which part of the fabric is stagnant and which part is convective in the padding bath.

The value $\alpha$ is related to the value of the forces or pressures that are extended onto the load during passing the rollers or squeezers. In figure 5.7 shows a schematic relationship between $\alpha$ and the pressure forces.

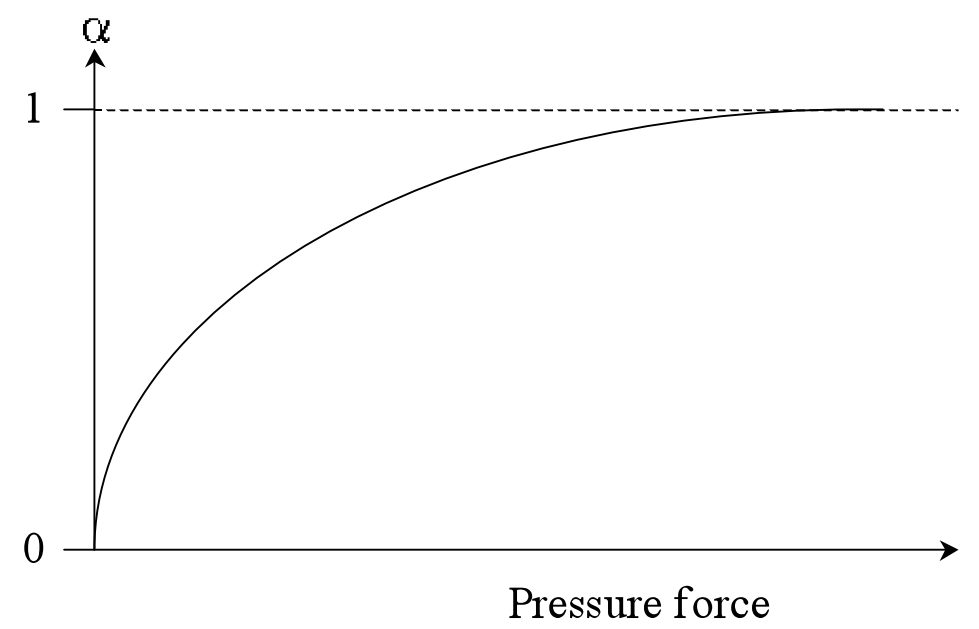

Figure 5.7: Expected relation between the squeezing factor $\alpha$ and the pressure force exerted onto a textile

The deformation parameter gives only information about the fraction of pores in which some flow can be generated due to the deformation. It does not give information about the magnitude of the flow in the pores. This value is dependent on the rate of deformation and not on the 
magnitude of deformation. The Peclet number represents the rate of deformation. This dimensionless number is defined as:

$P e=\frac{\text { Convective_mass_transfer }}{\text { Diffusive_mass_transfer }}=\frac{\bar{v}_{P} L_{P}}{D}$

in which $\bar{v}_{P}$ is the mean liquid velocity in the pores in $\mathrm{m} / \mathrm{s}$ and $L_{P}$ is the length of the pores in $\mathrm{m}$. This parameter is related to the liquid velocities generated in the pores because these depend directly on the deformation rate. The higher the rate of deformation the higher the induced pore velocities will be. It can be argued that the pore liquid velocities that are in fact the liquid displacement velocities will be proportional to the pore deformation rate as drawn schematically in figure 5.8 .

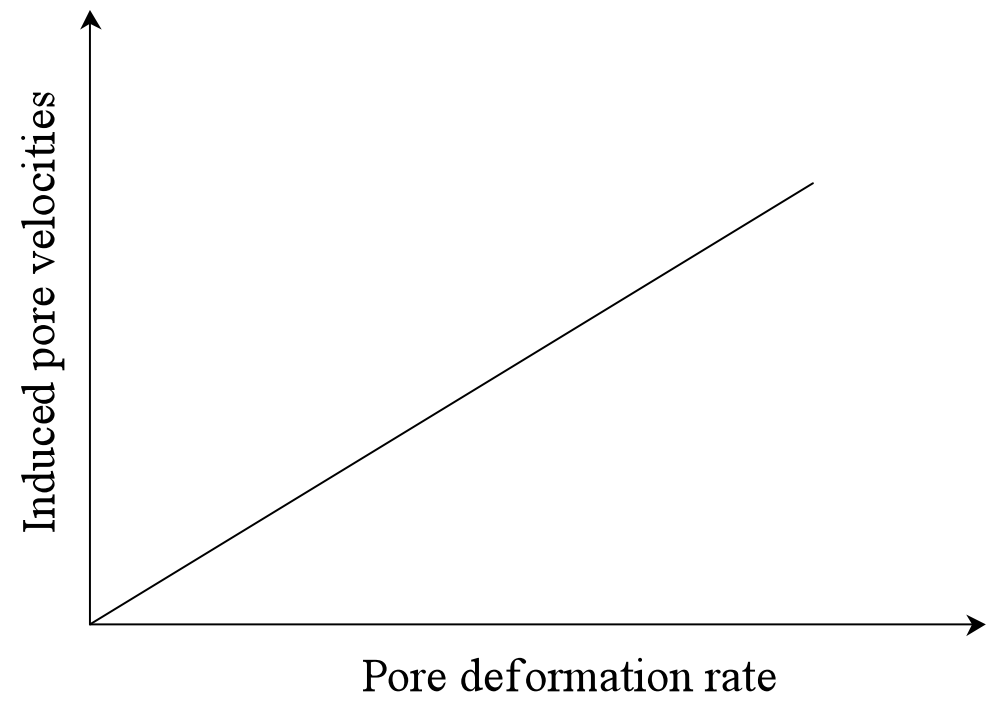

Figure 5.8: Expected relationships between the induced pore velocities and the pore deformation rate

A fabric is guided over rollers in a rinsing compartment. This is schematically drawn in figure 5.1. The fabric is deformed while passing the roller in the rinsing compartment. This deformation is caused by the tension on the fabric for transport through the equipment. The tension causes stretching of the fabric at the upper-side on the roller and compression on the downside of the fabric on the roller. This is schematically drawn in figure 5.9. It is clear that the stagnant core will be 'pushed' downwards and thus that a bigger part of the convective shell is at the upper side of the fabric. In fact we see here a 'dynamic' stagnant core. The stretching and compressing of the fabric results in pore deformation, which induces a liquid flow in the capillary of the fabric. 


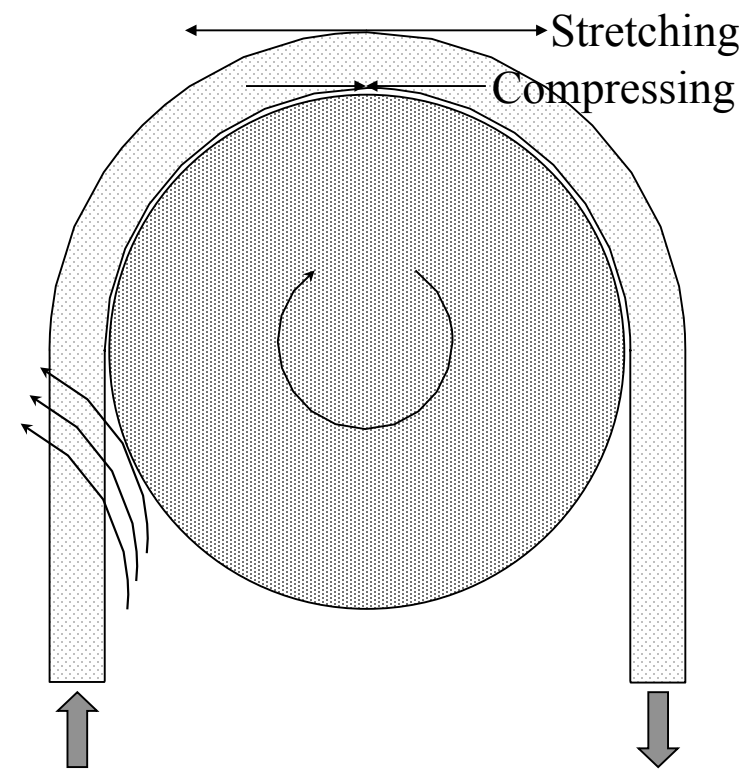

Figure 5.9: Schematic drawing of stretching and compressive forces on a roller leading to deformation of pores

Suppose an enzyme padding process with a particular value of the squeezing factor $\alpha$ and of $\mathrm{Pe}$, then the curve that describes the concentration of enzymes in the fabric as a function of time looks as schematically drawn in figure 5.10.

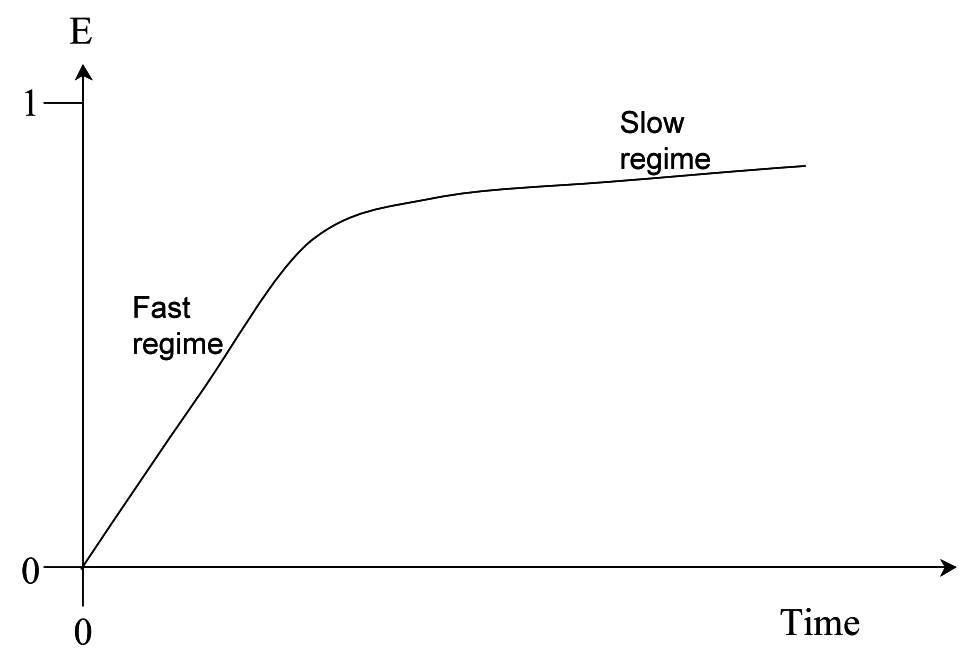

Figure 5.10: Expected enzyme concentration in the fabric as function of time for a particular value of $\alpha$ and $\mathrm{Pe}$

In this figure the enzyme concentration is expressed in a factor $\mathrm{E}$, which is the ratio between the actual enzyme concentration in the fabric and the concentration that is achievable after infinite long time:

$E=\frac{C_{E, f, t}}{C_{E, f, \infty}}$ 
where $C_{E, f, t}$ is the average enzyme concentration in the fabric at time $\mathrm{t}$ and $C_{E, f, \infty}$ is the enzyme concentration in the fabric after infinite long time. The curve in fig. 5.10 shows two regimes; a fast and a slow increase of the enzyme concentration. The fast part of the curve represents the convective transfer process, while the slow part of the curve shows the relatively slow diffusion process. A value for the squeezing factor $\alpha$ can be obtained by a short cut method that approximates the two regimes by straight lines, as shown in figure 5.11 .

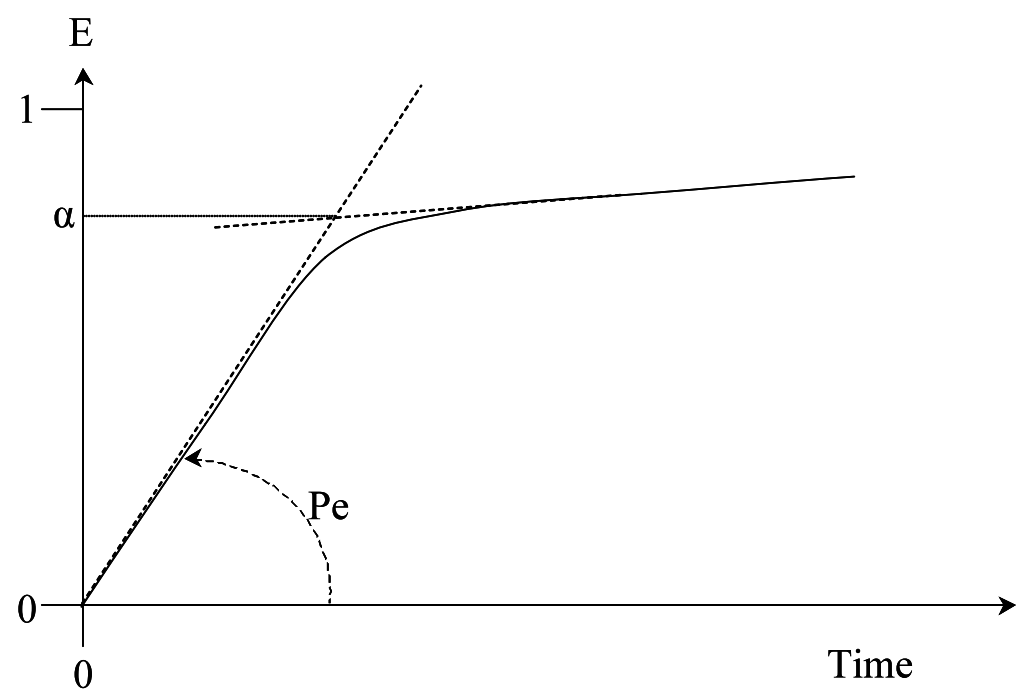

Figure 5.11: Short-cut method to determine the value of the squeezing factor a graphically

It can be argued that the value $E$ at the cross point is also the value of $\alpha$. It is the point where the convective transport is changed into diffusion transport. The angle of the fast regime is proportional to the Pe-number as indicated in figure 5.11 because $\mathrm{Pe}$ represents the rate of fabric deformation and thus for the rate of convectional transport. To clarify the concepts of the squeezing factor $\alpha$ and the Pe-number, figure 5.12 and figure 5.13 maybe helpful. In figure 5.12 three curves have been drawn, all for a constant value of $\alpha$ and three different values for Pe.

Because diffusion is identical for all three cases, the slow parts of the curve coincide at longer times. However, for high Pe-numbers the diffusion regime starts earlier because the convective transport is completed faster. 


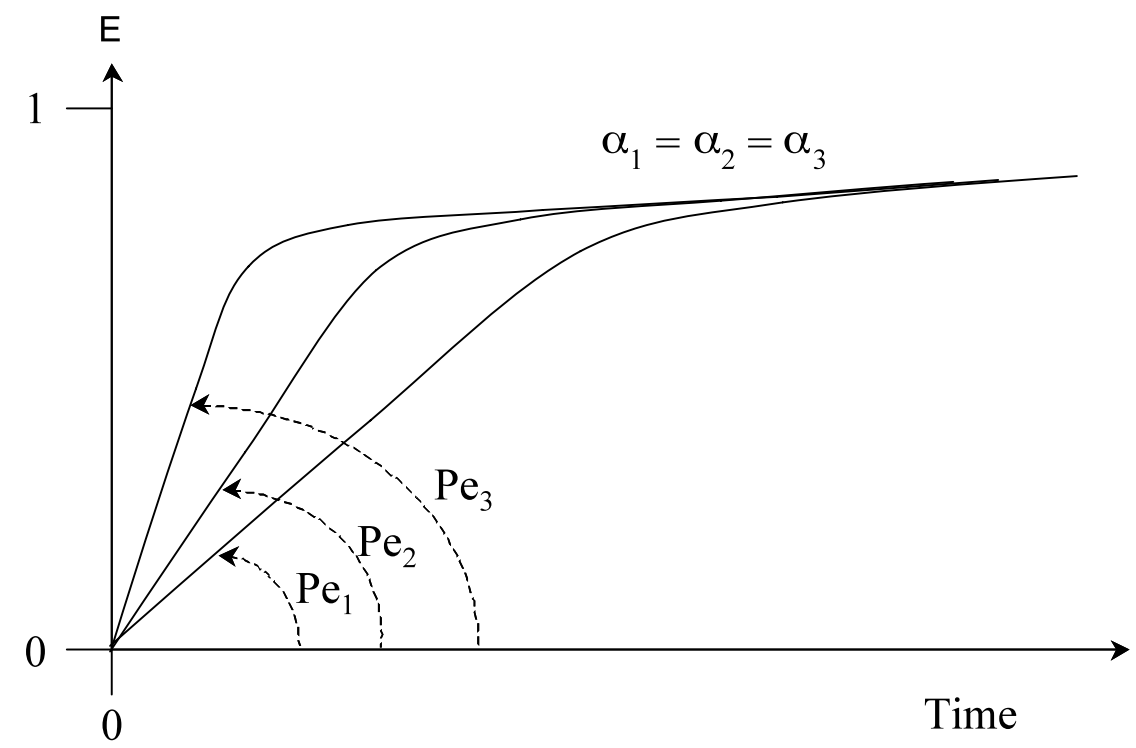

Figure 5.12: Three curves representing the transport of enzymes into a fabric as a function of time for different values of $\mathrm{Pe}$ and identical values of $\alpha$

Figure 5.13 shows three curves for three different values of $\alpha$ and for a constant value of the Penumber.

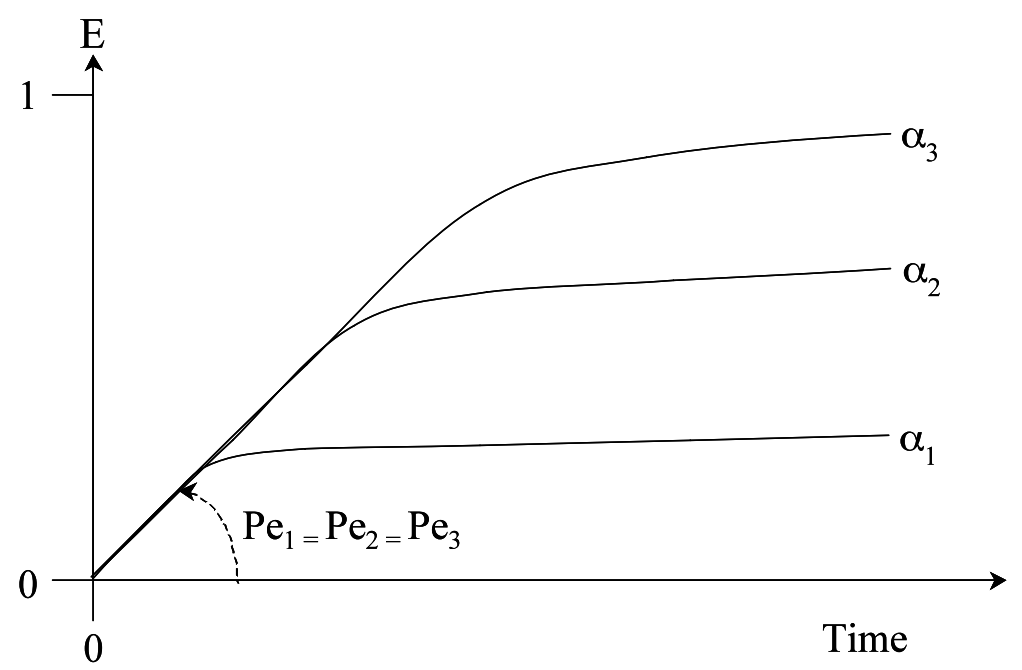

Figure 5.13: Three curves representing the transport of enzymes into a fabric as function of time for different values of $\alpha$ and a constant value of the Pe-number

The rate of convective transport is in figure 5.13 for all cases the same because the deformation rate is constant. However for high values of $\alpha$, the extent of deformation is higher leading to a higher value of $E$ at which the diffusion regime starts. 


\subsection{A mass transfer model}

The mass transfer in a fabric can be modelled using the squeezing factor $\alpha$, as described in section 5.4. The model describes the mass transfer of enzymes in a rinsing process from the fabric into the bulk, i.e. the rinsing bath. Because the impregnation of fabrics by enzymes from an enzymatic solution is just the other way around, the model can easily be applied for rinsing as well as for impregnation. The squeezing principles have been used to find the relation between the application of mechanical energy and mass transfer from the stagnant core to the convective shell and finally into the bulk.

As described earlier the following equations are valid for $\alpha$ :

$$
\begin{aligned}
& \alpha=\frac{d_{C}}{d_{f}} \Rightarrow d_{C}=\frac{\alpha}{d_{f}} \\
& 1-\alpha=\frac{d_{S}}{d_{f}} \Rightarrow d_{S}=(1-\alpha) d_{f}
\end{aligned}
$$

During rinsing the enzymes in the stagnant region of the fabric diffuse to the convective region. The enzymes in the convective region are transported to the bath by convection. The transfer coefficient for transport from the stagnant to the convective region is $k_{S}$ in $\mathrm{m} / \mathrm{s}$ and the transfer coefficient for transport from the convective regions to the bulk is $k_{C}$ in $\mathrm{m} / \mathrm{s}$. During the mass transfer, the enzyme concentration in the bulk liquid $C_{B}$ will increase. In the case of an impregnation process the bulk concentration will decrease. The model is a first approximation of the rinsing process and makes use of the mean concentrations in the stagnant and the convective regions with respect to place. The starting equation is a mass balance for the enzymes present in the total system. This balance is valid for all times.

$V_{W, f} C_{f, 0}=V_{W, S} C_{S}+V_{W, C} C_{C}+V_{W, B} C_{B}$

This balance assumes that there is initially a homogeneous enzyme concentration in the fabric $C_{f, 0} . V_{W, f}, V_{W, S}$ and $V_{W, C}$ are respectively the total water volume in the fabric, the water volume in the stagnant region and the water volume in the convective region. $C_{S}, C_{C}$ and $C_{B}$ are respectively the enzyme concentration in the stagnant region, the concentration in the convective region and the concentration in the liquid bath.

It is assumed that the water uptake due to the swelling of cotton is negligible.

Equation [5.11] delivers an expression for the bulk concentration:

$$
C_{b}=\frac{V_{W, f}}{V_{W, b}} C_{f, 0}-\frac{V_{W, S}}{V_{W, b}} C_{S}-\frac{V_{W, C}}{V_{W, b}} C_{C}
$$

and differentiation to time gives: 
$\frac{d C_{b}}{d t}=-\frac{V_{W, S}}{V_{W, b}} \frac{C_{S}}{d t}-\frac{V_{W, C}}{V_{W, b}} \frac{d C_{C}}{d t}$

The mass transfer from the stagnant region to the convective region can be written as:

$V_{W, S} \frac{d C_{S}}{d t}=-2 k_{S} A\left(C_{S}-C_{C}\right)$

or:

$\frac{d C_{S}}{d t}=-\frac{2 k_{S} A}{V_{W, S}}\left(C_{S}-C_{C}\right)$

where $A$ is the surface area of the textile over which the transfer takes place. The factor 2 is because a double side transfer is considered here (figure 5.6).

The mass transfer from the convective region to the bulk can be written as:

$V_{W, C} \frac{d C_{C}}{d t}=2 k_{S} A\left(C_{S}-C_{C}\right)-2 k_{C} A\left(C_{C}-C_{b}\right)$

or:

$\frac{d C_{C}}{d t}=\frac{2 k_{S} A}{V_{W, C}}\left(C_{S}-C_{C}\right)-\frac{2 k_{C} A}{V_{W, C}}\left(C_{C}-C_{b}\right)$

The mass transfer coefficient in the stagnant region is approximated by:

$k_{S}=\frac{D}{0.5 d_{S}}$

Due to the double sided transfer the diffusion in each direction is over half the thickness of the stagnant core. It is assumed that the transfer coefficient in the convective region $k_{C}$ is 100 times higher than $\mathrm{ks}_{\mathrm{s}}$.

The set of differential equations $5.13,5.15$ and 5.17 can be solved numerically.

Further the liquid to cloth ratio (LCR) and the fabric porosity are introduced to create appropriate expressions for $V_{W, f}, V_{W, S}, V_{W, C}$ and $V_{W, b}$. The fabric porosity $(\varepsilon)$ can be described assuming that a fabric is a porous plate and that the threads and fibres are massive. Then the proportion of the empty space in the fabric is characterised by the fabric porosity. So the volume of a fabric is defined as: 
$V_{f}=(1-\varepsilon) d_{f} A$

The LCR is defined as:

$L C R=\frac{W_{W, b}}{W_{f}}=\frac{V_{W, b} \rho_{W}}{V_{f} \rho_{f}}=\frac{V_{W, b} \rho_{W}}{(1-\varepsilon) A d_{f} \rho_{f}}$

in which $\rho_{\mathrm{W}}$ is the density of the liquid in the bath in $\mathrm{kg} / \mathrm{m}^{3}$ and $\rho_{\mathrm{f}}$ is the density of the fabric in $\mathrm{kg} / \mathrm{m}^{3}$. From equation [5.19] the following expressions can be derived:

$W_{f}=(1-\varepsilon) V_{f} \rho_{f}$

$W_{W, b}=L C R \times W_{f}$

Equation [5.20] can be rewritten as:

$V_{W, b}=L C R(1-\varepsilon) A d_{f} \frac{\rho_{f}}{\rho_{W}}$

Using the expression [5.21] and [5.22] the equation [5.23] can be rewritten as:

$V_{W, b}=\frac{W_{W, b}}{\rho_{W}}$

The volume water in the fabric $\left(V_{W, f}\right)$, the volume of water in the convective region $\left(V_{W, C}\right)$ and the volume of water in the stagnant core $\left(V_{W, S}\right)$ can respectively be calculated as follows:

$V_{W, f}=\varepsilon d_{f} A$

$V_{W, C}=\varepsilon d_{C} A=\varepsilon \alpha d_{f} A=\alpha V_{f}$

$V_{W, S}=\varepsilon d_{S} A=\varepsilon(1-\alpha) d_{f} A=(1-\alpha) V_{f}$

The volumes are expressed in $\mathrm{m}^{3}$.

Further a dimensionless bulk concentration has been defined as:

$$
E=\frac{C_{b}}{C_{b, \infty}}
$$


with:

$\bar{C}_{b, \infty}=\frac{V_{W, f}}{V_{W, b}} C_{f, 0}$

Using Matlab some model calculations have been performed. The value of $E$ as function of time has been calculated for different values of $\alpha$.

The values of the parameters used for these calculations are:

Surface area of the fabric

Fabric thickness

$A_{f} \quad=1 \quad\left(m^{2}\right)$

Porosity of the fabric

$\mathrm{d}_{\mathrm{f}} \quad=0.5 \times 10^{-3}$

(m)

$\varepsilon \quad=0.5$

$(-)$

Liquid to cloth ratio

LCR $=5$

Density of the liquid

$\rho_{\mathrm{W}} \quad=1000$

Density of the fabric

$\rho_{\mathrm{f}} \quad=1200$

$\left(\mathrm{kg} / \mathrm{m}^{3}\right)$

$\left(\mathrm{kg} / \mathrm{m}^{3}\right)$

The calculations have been done for the initial condition $t=0, C_{b, 0}=0, C_{s, 0}=C_{c, 0}=0,05 \mathrm{~g} / \mathrm{l}$ and for 5 different values of $\alpha$. The results of the calculations are presented in figure 5.14.

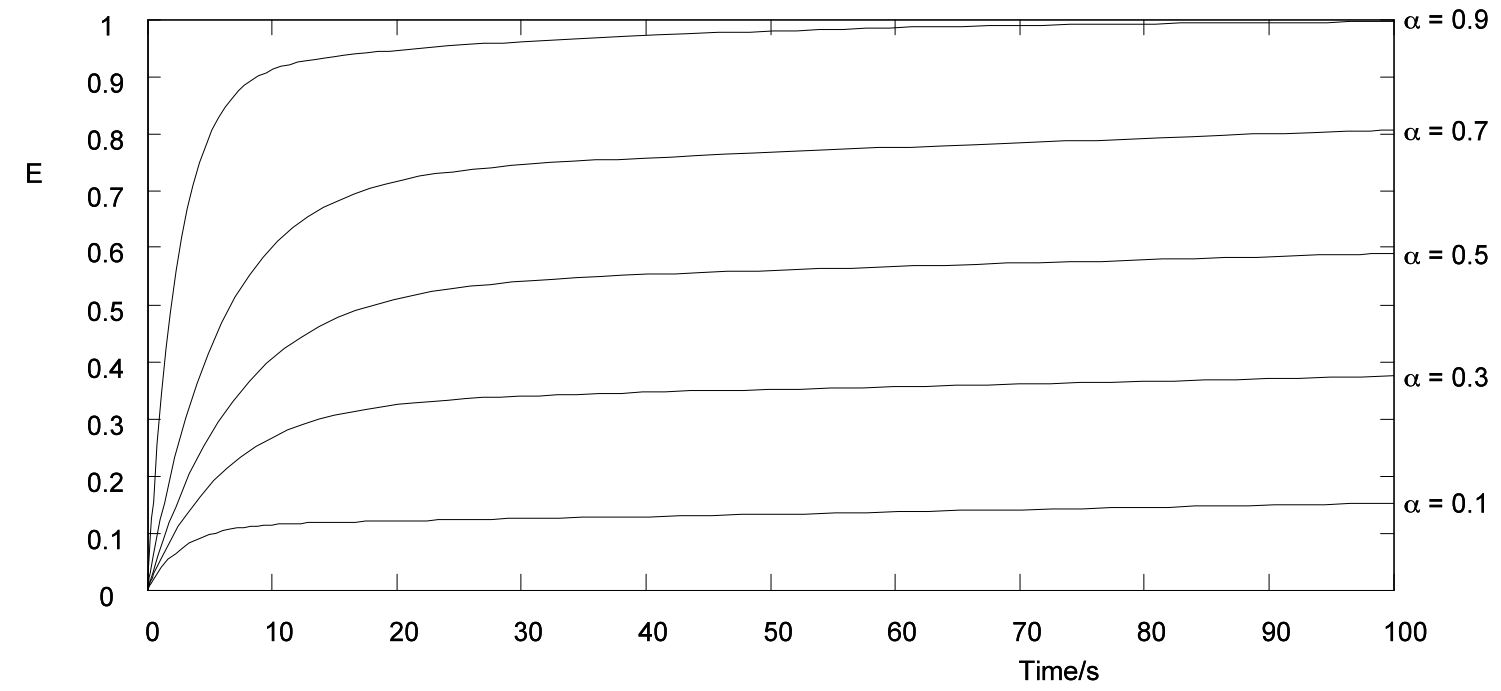

Figure 5.14: Results of the model calculations for the dimensionless enzyme concentration as a function of time for different $\alpha$

These model calculations confirm that the squeezing factor $\alpha$ has an all-dominating effect on the rate with which the enzymes are transferred from a fabric into a bath. 


\subsection{Adsorption limitation in textile pores}

The relatively high ratio of the surface area and the volume of the capillaries in the fabric form another problem in enzymatic textile treatment processes. The enzymes in the capillary liquid adsorb at the capillary surface until an adsorption-desorption equilibrium is achieved between the surface enzyme concentration and the enzyme concentration in the capillary liquid. This adsorption-desorption equilibrium reads:

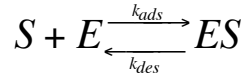

where $S$ is the number of sites at a substrate surface at which enzymes can be adsorbed. $E$ is the enzyme concentration in the liquid. $E S$ is the surface concentration of enzymes adsorbed at the surface and $k_{a d s}$ and $k_{\text {des }}$ are the adsorption rate constant and the desorption rate constant. To make the problem of suboptimal adsorption tangible, the next calculation example may be helpful.

For a capillary in a fabric, filled with a solution of the enzyme pectinase the characteristic properties of the capillary and the enzyme are:

- Capillary length, $L_{c a p}=0,1 \mathrm{~mm}$ i.e. the thickness of a yarn;

- Capillary diameter, $d_{\text {cap }}=2 \mu \mathrm{m}$, the intra yarn pore;

- Molecular weight of pectinase $M_{E}=50 \mathrm{kDa}=50 \mathrm{~kg} / \mathrm{mol}$;

- Specific weight of pectinase $\rho_{E}=1300 \mathrm{~kg} / \mathrm{m}^{3}$;

- Pectinase concentration in the solution $C_{E}=0.05 \mathrm{~g} / \mathrm{l}$ i.e. a frequently used concentration.

The surface area of the capillary $A_{c a p}$ can be calculated by:

$$
A_{c a p}=\pi d_{c a p} L_{c a p}
$$

and the volume of the capillary by:

$$
V_{c a p}=\frac{1}{4} \pi d_{c a p}^{2} L_{c a p}
$$

Using the values for the capillary length and capillary diameter as given above, results in $A_{\text {cap }}=6.3 \times 10^{-10} \mathrm{~m}^{2}$ and $V_{\text {cap }}=3.1 \times 10^{-16} \mathrm{~m}^{3}$.

If the enzyme is assumed to be a sphere, than its diameter can be calculated using

$$
d_{E}=\sqrt[3]{\frac{6 M_{E}}{N_{A V} \rho_{E} \pi}}
$$


in which $N_{A V}$ is the Avogadro number $\left(6 \times 10^{23} \mathrm{~mol}^{-1}\right)$.

From the values given above the enzyme diameter is $d_{E}=50 \AA$. This value is in accordance with values given in literature [Agrawal, 2005; website: proteindatabank].

These enzymes adsorb at the surface of the capillary and it is suggested here that they adsorb in a simple rectangular array. In that case the maximum number of enzymes adsorbed per $\mathrm{m}^{2}$ at the surface, $n_{\max }$ is:

$$
n_{\max }=\frac{1}{d_{E}^{2}}
$$

in which $d_{E}$ is the diameter of the enzyme in $\mathrm{m}^{1}$.

This means in this case that there are $n_{\max }=4 \times 10^{16}$ molecules adsorbed at the capillary surface per $\mathrm{m}^{2}$. The maximum surface concentration of enzymes, $\Gamma_{E, \max }$ can be calculated by:

$\Gamma_{E, \max }=\frac{n_{\max }}{N_{A V}}$

For this case the maximum surface concentration is: $\Gamma_{E, \max }=6.7 \times 10^{-8} \mathrm{~mol} / \mathrm{m}^{2}$. Therefore, the capillary surface area of $6.3 \times 10^{-10} \mathrm{~m}^{2}$ can contain at maximum $4.2 \times 10^{-17} \mathrm{~mol}$ pectinase. With an enzyme concentration $C_{E}$ of $0,05 \mathrm{~g} / \mathrm{l}$ in the capillary liquid and a capillary liquid volume of $3.1 \times 10^{-16} \mathrm{~m}^{3}$, the number of moles of pectinase in the liquid is calculated as $3.1 \times 10^{-19}$. So this example shows that the availability of pectinase in the capillary liquid is much lower than the number of moles of pectinase that can be adsorbed at the capillary wall. However, in the case of enzymes, there is always an adsorption-desorption equilibrium. From the calculations made here it is clear that the enzyme concentration in the capillary liquid will decrease immediately as a result of the adsorption process, leading to a lower equilibrium concentration at the surface. If the capillary liquid is not refreshed this results in a surface concentration that is much lower than can be expected for particular enzyme concentrations in the liquid. There will be some transfer of enzymes from the inter yarn liquid to the intra yarn liquid by diffusion. However this is a relatively slow process as shown above and therefore it is expected that the desorption process becomes controlled by diffusion.

\section{Experimental studies}

In this chapter it has been explained that mass transfer and adsorption limitation are dominating factors in enzymatic wet-textile processes. The squeezing factor $\alpha$ and the rate of deformation of a fabric the Pe-number are dominating the mass transfer. In a new developed device the influence of the squeezing and fabric deformation is qualitatively investigated and compared with 
the model calculations that are shown in figure 5.14. The release of the enzyme amylase from a pre-treated fabric is measured with different squeezing intensities.

\section{Experimental set-up}

For this experiment a device for the release of enzymes from the fabric has been developed. The aim of this device is to study the enzyme release of the fabric as a function of the squeezing intensity. The experimental set-up is schematically drawn in figure 5.15 . Figure 5.16 shows a detailed photograph of the part of the device that contains the fabric. The release device consists of two cylinders. The inner cylinder contains the fabric. So the enzymes are 'released' from the fabric in the inner cylinder to the outer cylinder. Here the bulk is stirred with a magnetic stirrer at low speed. The function of the inner cylinder is to allow the transfer of enzymes from the fabric to the bulk without creating a liquid flow in the inner cylinder.

During the experiment the fabric is placed in the inner cylinder where it is fixed with needles to the wall of the inner cylinder (1). The fabric is fixed at the top to the cover (2) of the inner cylinder. The cover is connected to a screw and can be rotated independent from the cylinder. So rotation of the cover of the cylinder leads to squeezing the fabric and thus to mass transfer that is induced by mechanical energy.

The inner cylinder has a diameter of $21.3 \mathrm{~mm}$ and a height of $90 \mathrm{~mm}$. This cylinder has 320 holes with a diameter of $2.0 \mathrm{~mm}$. The inner cylinder is placed in a $500 \mathrm{ml}$ glass beaker. The liquid in the glass beaker is stirred with a magnetic stirrer. The liquid from the beaker is pumped to the flow cell in the spectrophotometer and pumped back into the glass beaker. The pump is set at a speed of $48 \mathrm{rpm}$ and pumps $10 \mathrm{ml} /$ minute. The sum of the liquid volume in the tubes and in the flow cell is $5.0 \mathrm{ml}$. 


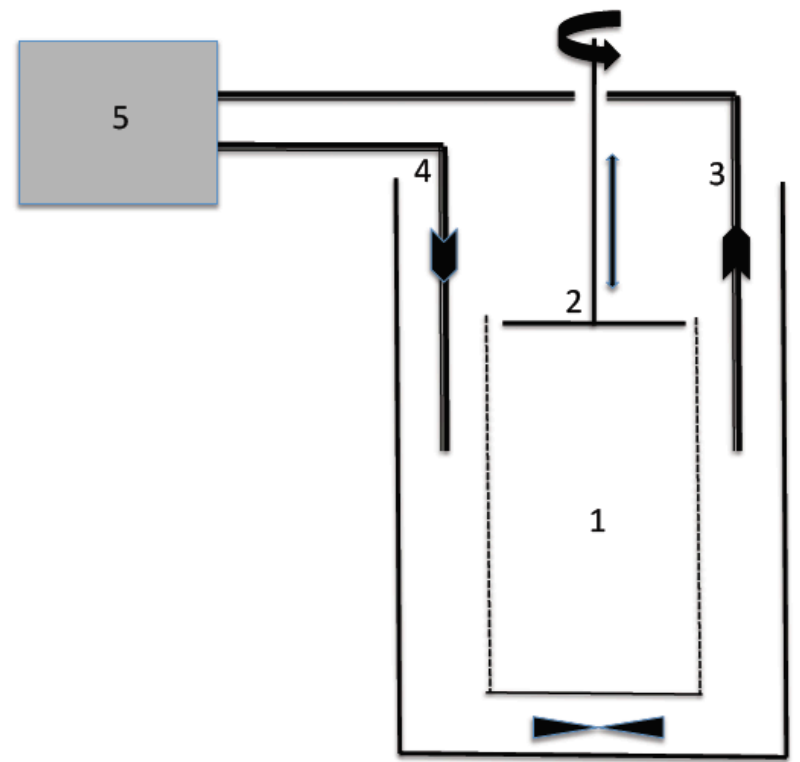

Figure 5.15: Schematic drawing of the release device

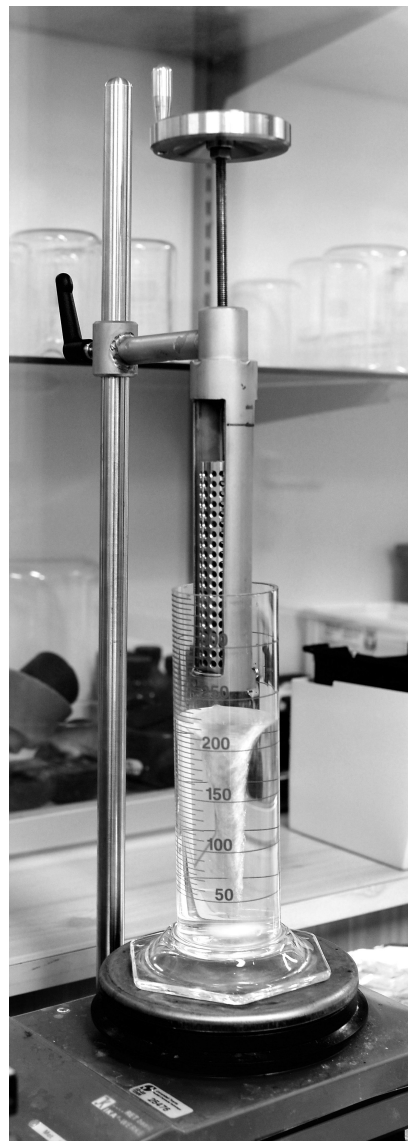

Figure 5.16: Photograph of the release device

\section{Materials}

The experiments are done with a desized, scoured and bleached percale fabric. The dry weight of the fabric is $130 \mathrm{~g} / \mathrm{m}^{2}$. The fabric is conventionally pre-treated. The pre-treatment steps are: singeing and desizing, followed by "bio-scouring" with pectinase followed by a hot rinse. Thereafter the fabrics are scoured with alkaline and bleached (hot peroxide bleach) in rope form. Vlisco BV in The Netherlands supplied the fabrics. The dimensions of the cotton fabric samples are $73 \times 9 \mathrm{~cm}$. The samples are impregnated during two hours with an enzyme solution containing $5 \mathrm{ml} / \mathrm{l}$ amylase commercially available as Optisize Flex from Genencor. This product contains a pure enzyme concentration of $1 \%$. After impregnation the fabric is dried on a clothesline and conditioned at $20^{\circ} \mathrm{C}$ and $65 \%$ relative humidity during 24 hours in a climate chamber.

\section{Measuring method}

The release of the enzymes from the fabric is measured with a UV-VIS spectrophotometer Cary 100 Bio (Varian). The released enzyme is pumped from the bulk to the flow cell in the spectrophotometer and back to the bulk. The adsorption spectra of amylase have been measured for different aqueous solutions, as shown in figure 5.17. The measurements were repeated several times for the same solution. It has been noticed that enzyme solution shows a peak at different wavelength depending on the concentration amylase. Optisize Flex is stabilized 
for storage purposes. It is believed that this product is not adequate stabilized for further dilution and storage and that therefore the peak shows different wavelength depending on the concentration. The instability of the diluted enzyme solution is confirmed as this solution showed flocculation after few hours storage at room temperature. The cotton fabric is impregnated with an amylase solution that contains $5 \mathrm{~g} / \mathrm{l}$ Optisize Flex, which will result in further dilution when the enzyme is released. Therefore the lowest measurable wavelength of $195 \mathrm{~nm}$ is chosen, which corresponds with an enzyme concentration of $1 \mathrm{~g} / \mathrm{l}$ Optisize Flex.

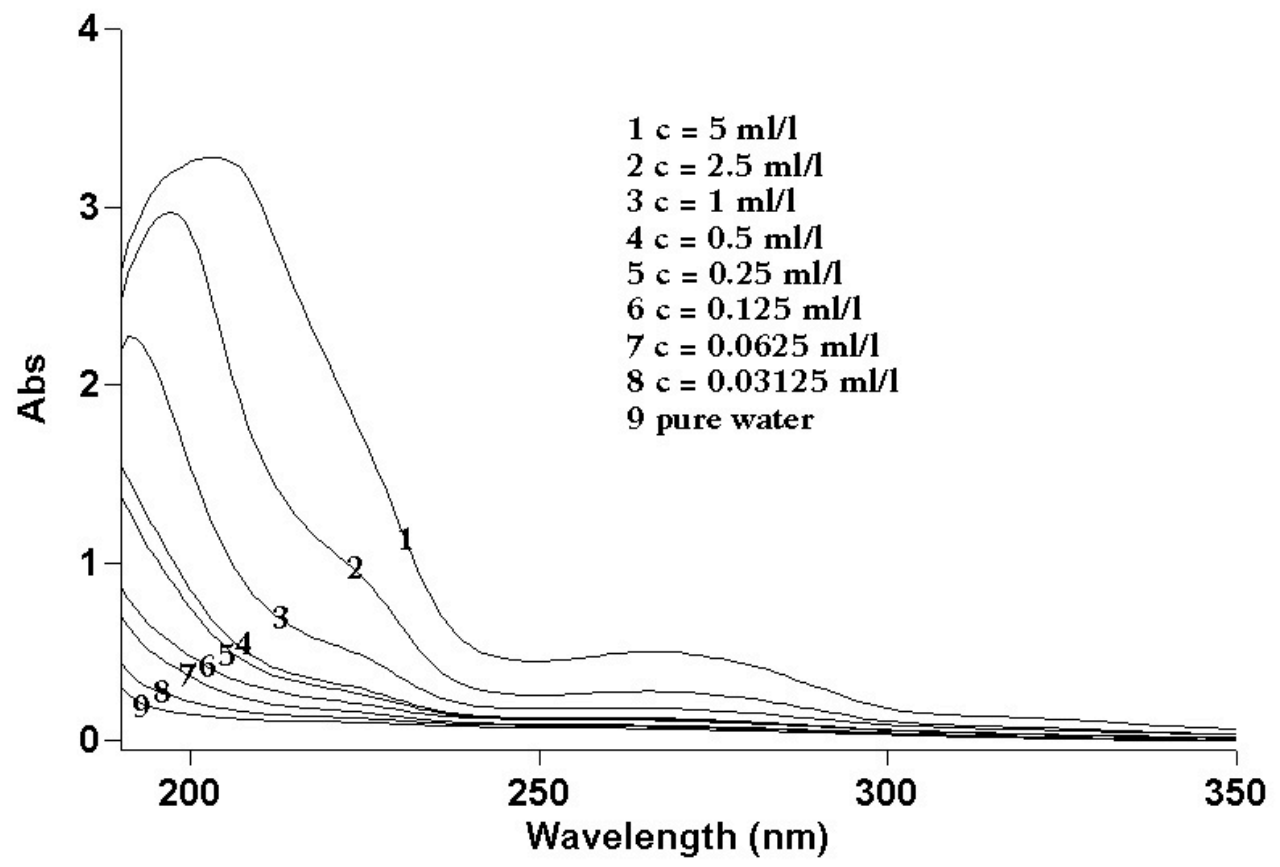

Figure 5.17: Absorption peaks for different concentrations amylase

Measurements are carried out to obtain the relation between concentration of the released enzymes of the fabric and absorption. The calibration curve is used to obtain the relation between absorption and concentration. This curve is shown in figure 5.18. 


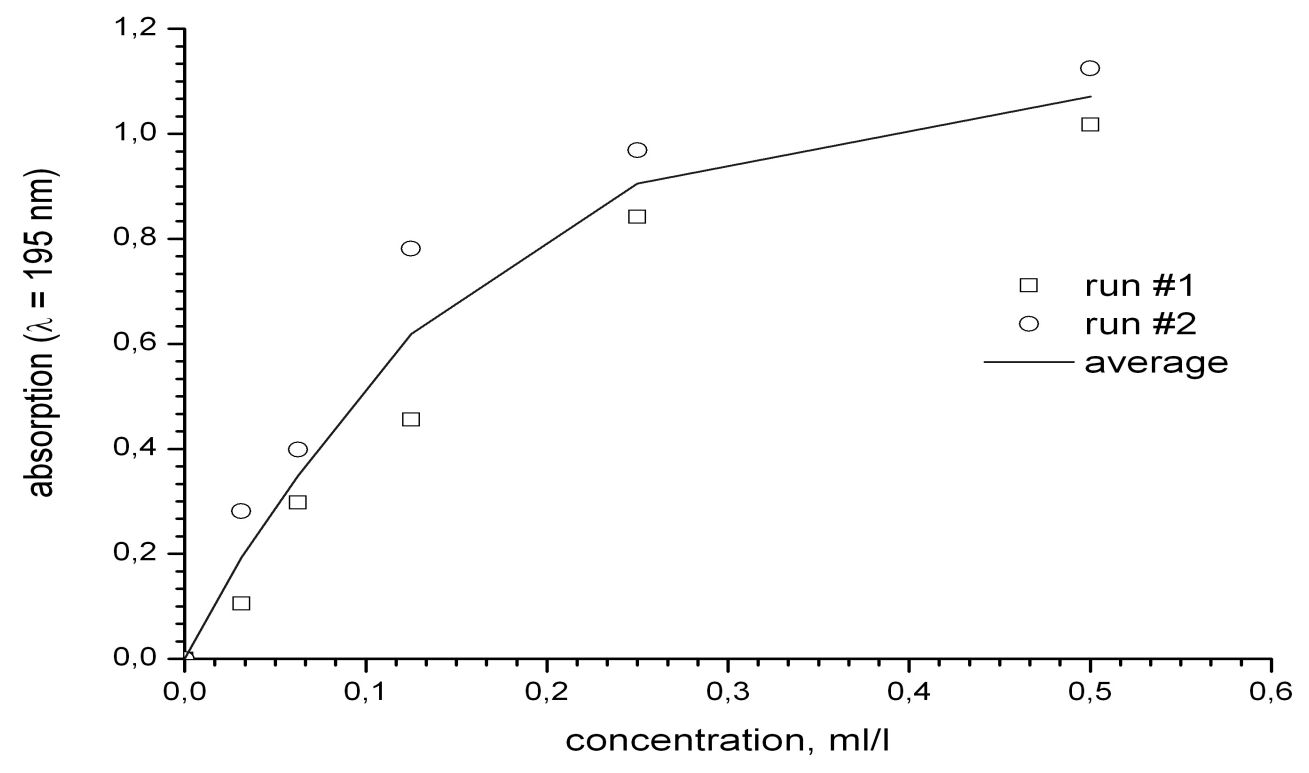

Figure 5.18: Absorption vs concentration curve

The response time of the system is evaluated to validate the measured enzyme release. It has been established that actual measurements are in an order of magnitude of 10 minutes. The response time of the system is less than $12 \mathrm{~s}$, which is fast enough. The result of the response time measurement is shown in figure 5.19. In this experiment the absorption of amylase as a function of time is shown. The wavelength of $195 \mathrm{~nm}$ was chosen as the adsorption maximum, which was detected for the lowest enzyme concentration. In this experimental run, $5 \mathrm{ml}$ of a 5 $\mathrm{ml} / / \mathrm{l}$ stock solution was added to $100 \mathrm{ml}$ water in a glass cylinder. A magnetic stirrer was placed inside the glass cylinder. After $12 \mathrm{~s}$, the UV/Vis spectrophotometer detected absorbance of amylase. A pump was used at the highest velocity of $48 \mathrm{~min}^{-1}$.

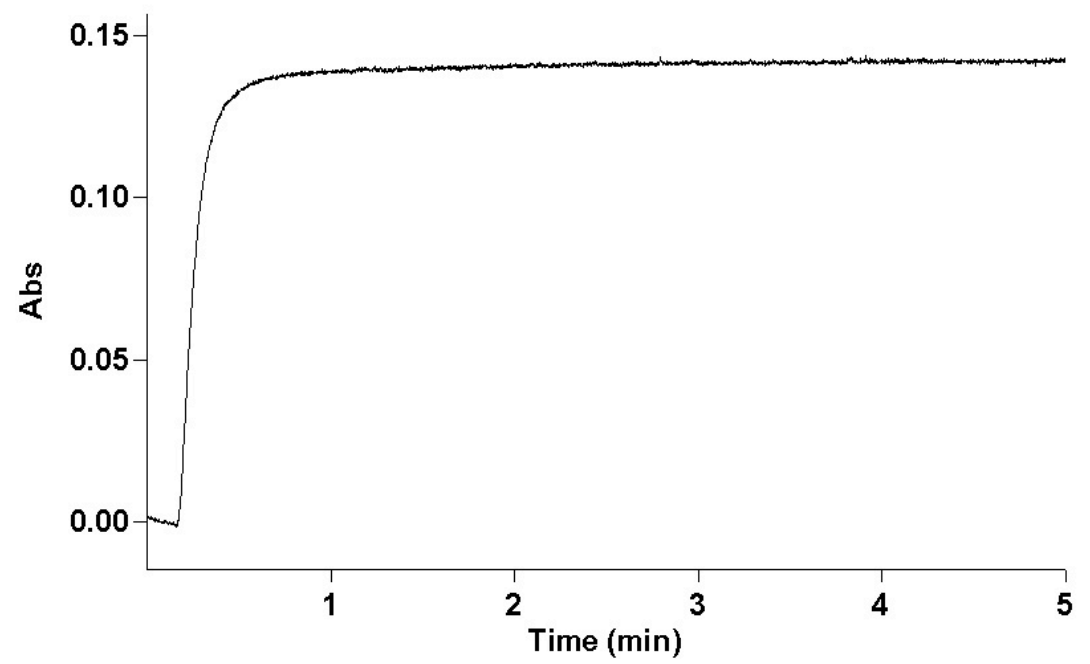

Figure 5.19: Response time of measurement system 


\section{Experiments}

The samples that are impregnated with amylase are rolled to fit it in the inner cylinder of the experimental device. After the fixation of the sample in the devise the bulk liquid (200ml) is added to the beaker and the release is measured. The mechanical energy is applied to the fabric by twisting. The twist is a $180^{\circ}$ rotation of the rolled fabric in the inner cylinder, immediately followed by detwisting, $-180^{\circ}$ turn of the fabric. The following release experiments of the enzyme amylase are carried out:

1. no application of mechanical energy;

2. twist every 5 minutes;

3. twist every 1 minute.

All experiments are repeated three times and the average value is reported.

Control measurement of the impregnation liquid after impregnation of the fabrics showed no substantivity of the enzyme for the fabric. This means that 'bonding' does not hinder the release of the enzyme amylase.

Result

The release of the enzyme from the fabric is plotted in figure 5.20. In this graph the results of three experiments with varying mechanical energy, as described before, are shown. It is clear from the experimental result that application of an increasing quantity of mechanical energy enhances the release of the enzyme from the fabric to the bulk. As such the figure corresponds well with the calculated curves in figure 5.14 according to equation [5.25].

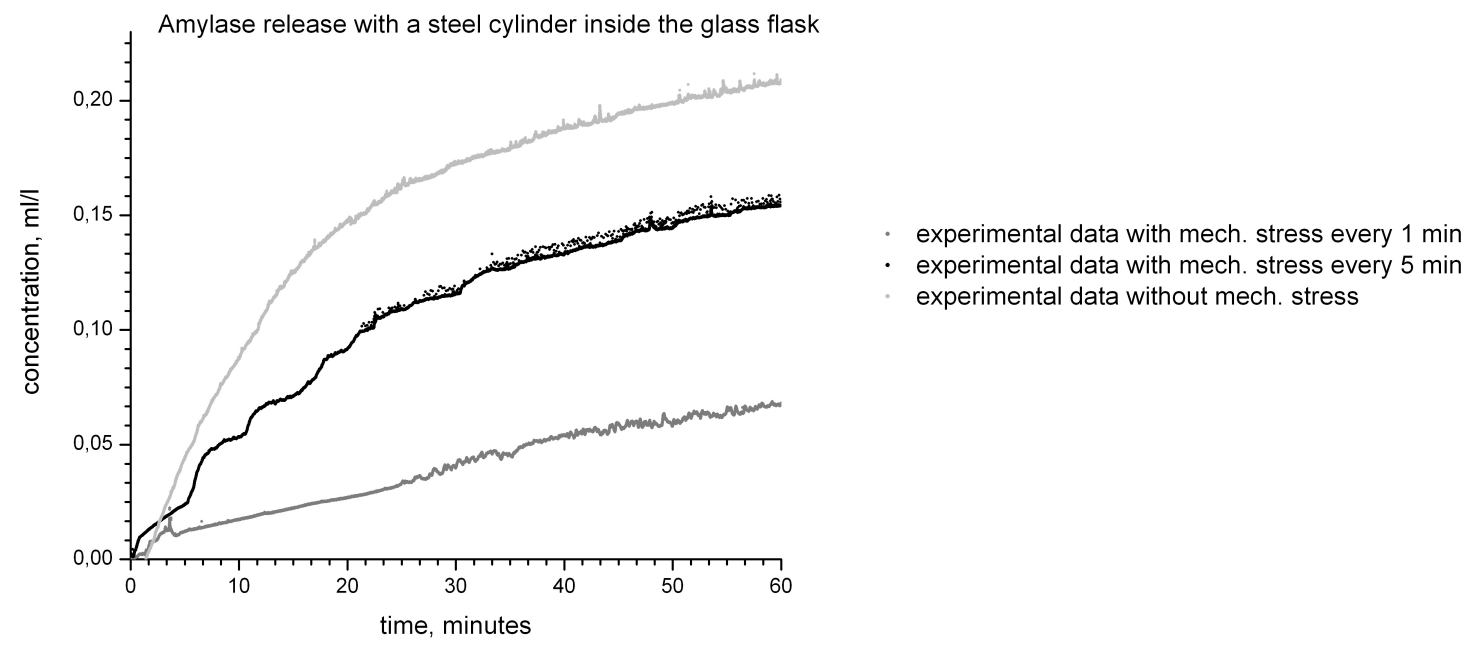

Figure 5.20: Release of amylase from a fabric to the bulk with variations in the applied mechanical energy as a function of time

From the graph it is clear that not only a increases with increasing quantity mechanical energy, but also the value of the Pe-number increases. In the current experimental procedure it was not possible to discriminate between those two parameters. 


\subsection{Modelling the adsorption limitation in textile pores}

Now in most models, describing the adsorption of enzymes at surface it is always assumed that the enzyme concentration in the liquid bulk does not change due to the adsorption. However this assumption is only valid if the bulk volume is very big compared to the available surface. Since in capillary systems it is the other way around, the bulk liquid volume is much smaller compared to the available surface and the assumption of a constant enzyme concentration cannot be made. This phenomenon leads to a more complex model.

The adsorption of enzymes at a substrate surface has been drawn schematically in figure 5.21.

\section{Enzymatic solution}

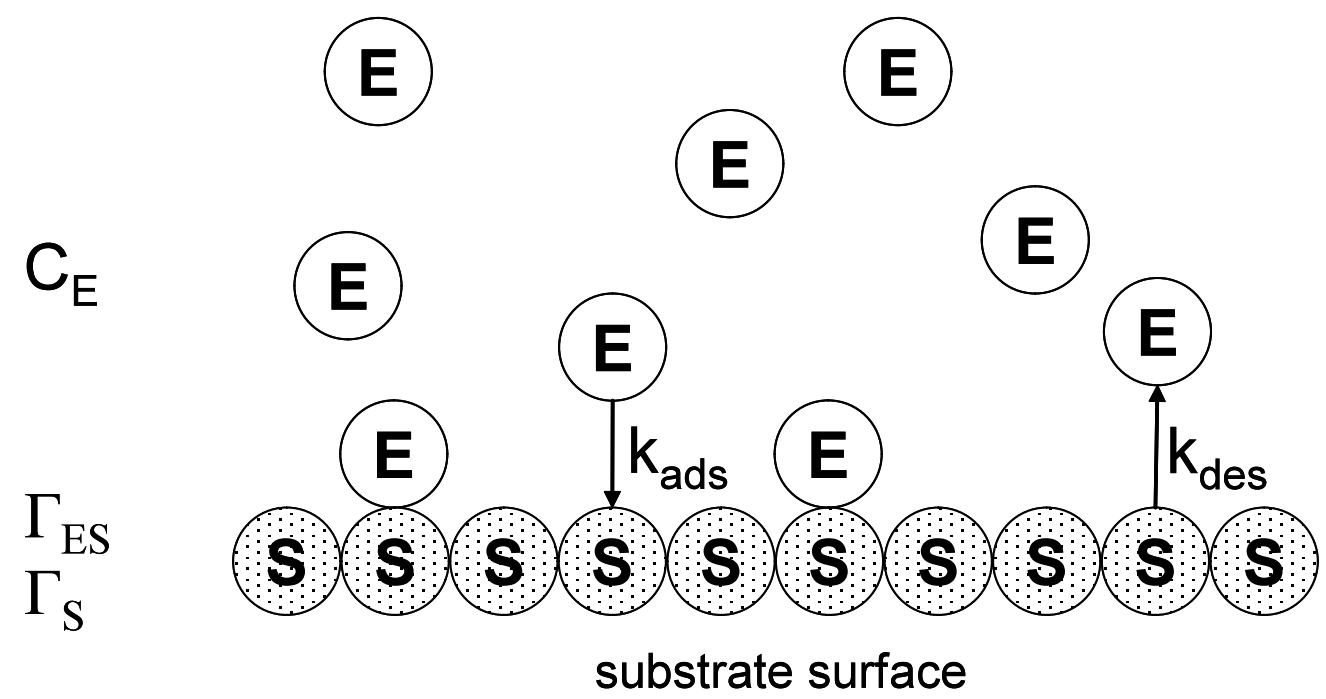

Figure 5.21: Schematical view of enzymatic adsorption-desorption at a substrate surface

The rate equation for the enzyme adsorption at the surface $\Gamma_{E S}$ follows from the adsorptiondesorption equilibrium, equation [5.30]:

$A_{C} \frac{d \Gamma_{E S}}{d t}=k_{a d s} V_{C} C_{E} A_{C} \Gamma_{S}-k_{d e s} A_{C} \Gamma_{E S}$

in which $A_{C}$ is the surface area of the capillary wall, $V_{C}$ is the volume of the capillary. It is assumed that this volume is totally filled with enzymatic solution, so $V_{C}$ is also the volume of the enzymatic solution in the capillary. $C_{E}$ is the enzyme concentration in this liquid. $\Gamma_{S}$ and $\Gamma_{E S}$ are the surface concentrations in $\mathrm{mol} / \mathrm{m}^{2}$ of the available sites for enzyme adsorption and the adsorbed enzymes respectively.

The mass balance for the total amount of enzymes in the system is: 
$V_{C} C_{E}=V_{C} C_{E, 0}-A_{C} \Gamma_{E S}$

with $C_{E, 0}$ is the initial concentration of enzymes in the solution.

So the amount of enzymes in the solution equals the initial amount of enzymes in the solution minus the amount of enzymes that has been adsorbed at the capillary surface. The number of available sites for enzyme adsorption can be related to the maximum amount of enzymes that can be adsorbed:

$\Gamma_{S}=\Gamma_{E S, \max }-\Gamma_{E S}$

The number of vacancies $S$, varies from $A_{C} \Gamma_{E S, \max }$, for $\Gamma_{E S}=0$ until 0 for $\Gamma_{E S}=\Gamma_{E S \text {,max }}$. In the latter case enzymes occupy all places.

With equation [5.38], the equations [5.36] and [5.37] can be rewritten as:

$$
\begin{aligned}
& \frac{d \Gamma_{E S}}{d t}=k_{a d s} V_{C} C_{E}\left(\Gamma_{E S, \max }-\Gamma_{E S}\right)-k_{d e s} \Gamma_{E S} \\
& C_{E}=C_{E, 0}-\frac{A_{C}}{V_{C}} \Gamma_{E S}
\end{aligned}
$$

Substitution of equation [5.40] into equation [5.39] and simplifying gives:

$\frac{d \Gamma_{E S}}{d t}=k_{a d s} V_{C} C_{E, 0} \Gamma_{E S, \max }-\left(k_{a d s} A_{C} \Gamma_{E S, \max }+k_{a d s} V_{C} C_{E, 0}+k_{d e s}\right) \Gamma_{E S}+k_{a d s} A_{C} \Gamma_{E S}^{2}$

For the initial conditions $t=0, C_{E}=C_{E, 0}$ and $\Gamma_{E S}=0$ reads the solution of this equation

$$
\Gamma_{E S}=\psi-\frac{2 \alpha \psi+\beta}{\left(\frac{\beta}{\psi}+\alpha\right) e^{-(2 \alpha \psi+\beta) t}+\alpha}
$$

with

$\psi=\frac{-\beta+\sqrt{\beta^{2}-4 \alpha \gamma}}{2 a}$

in which: 
$\alpha=k_{a d s} A_{C}$

$\beta=-\left(k_{a d s} A_{C} \Gamma_{E S, \max }+k_{a d s} V_{C} C_{E, 0}+k_{d e s}\right)$

$\gamma=k_{a d s} V_{C} C_{E, 0} \Gamma_{E S, \max }$

If the amount of adsorbed enzyme is small compared to the amount available in the liquid bulk, the model becomes simpler. In that case it may be assumed that the enzyme concentration in the bulk is constant and equal to $C_{E, 0}$. In that case equation [5.36] becomes:

$$
A_{C} \frac{d \Gamma_{E S}}{d t}=k_{a d s} V_{C} C_{E, 0} A_{C} \Gamma_{E}-k_{d e s} A_{C} \Gamma_{E S}
$$

Substitution of equation [5.38] and simplification gives:

$$
\frac{d \Gamma_{E S}}{d t}=k_{a d s} V_{C} C_{E, 0} \Gamma_{E S, \max }-\left(k_{a d s} V_{C} C_{E, 0}+k_{d e s}\right) \Gamma_{E S}
$$

So this equation describes the dynamics of the adsorption process in the case that the enzyme concentration in the capillary liquid does not change due to the adsorption process, what is the case when there is an excess of enzymes in the solution. The solution of this equation for the initial conditions $t=0$ and $\Gamma_{E S}=0$ reads:

$$
\Gamma_{E S}=\frac{k_{a d s} V_{C} C_{E, 0} \Gamma_{E S, \max }}{k_{a d s} V_{C} C_{E, 0}+k_{d e s}}\left[1-e^{-\left(k_{a d s} V_{C} C_{E, 0}+k_{d e s}\right) t}\right]
$$

With the two model equations [5.42] for adsorption without refreshment and [5.47] adsorption with refreshment some calculations are performed to show clearly the effect of the decreasing enzyme concentration in the capillary liquid during adsorption of enzymes at the capillary wall. For the example the values from section 5.5 are used:

$$
\begin{array}{lll}
A_{C} & =6 \times 10^{-10} & \mathrm{~m}^{2} \\
V_{C} & =3 \times 10^{-16} & \mathrm{~m}^{3} \\
C_{E, 0} & =0.001 & \mathrm{~mol} / \mathrm{m}^{3} \\
\Gamma_{E S, \text { max }} & =6.7 \times 10^{-8} & \mathrm{~mol} / \mathrm{m}^{2}
\end{array}
$$

The values for the adsorption and desorption coefficients are assumed to be:

$$
k_{\text {ads }}=5 \times 10^{18} \mathrm{~mol}^{-1} \mathrm{~s}^{-1} \text { and } k_{\text {des }}=0.5 \mathrm{~s}^{-1}
$$

The results are expressed in the enzyme concentration at the surface of the capillary in mol as a function of time. It is assumed that the capillaries are equal and the enzyme concentration at $t=0$ is in both capillaries $0.001 \mathrm{~mol} / \mathrm{m}^{3}$. Figure 5.22 shows the results if equation [5.47] has been 
used. In this case the adsorption is complete after $2 \mathrm{~s}$. So this is the case when there is an excess of enzymes available for adsorption.

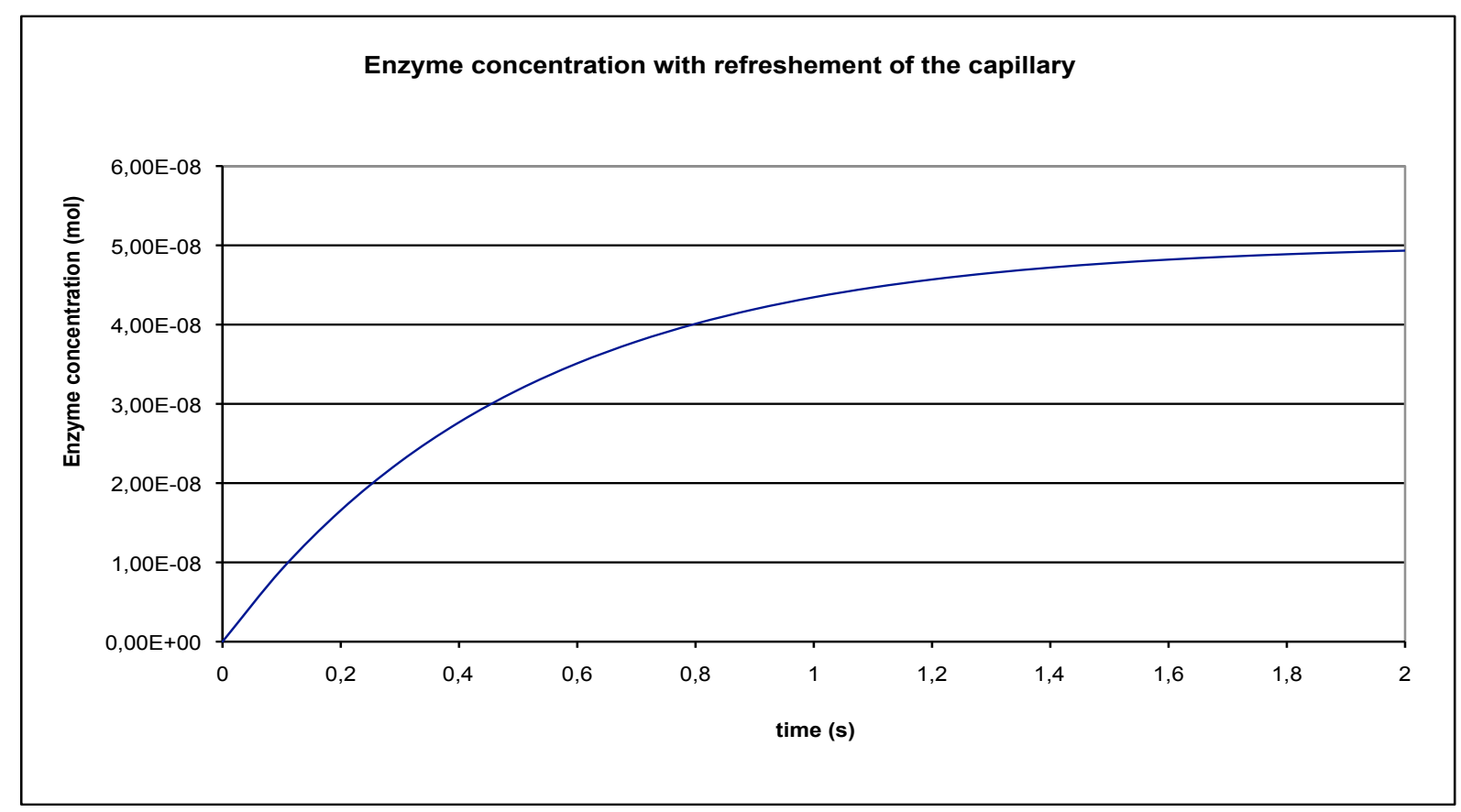

Figure 5.22: Model calculations for the adsorption dynamics of enzymes at a surface according to equation [5.47]

From equation [5.47] it can be calculated that the enzyme concentration after infinite time equals $\Gamma_{E S \text {,max }}$. Figure 5.22 shows that the enzyme concentration at the surface of the capillary is $5 \times 10^{8} \mathrm{~mol}$. This means that the dimensionless enzyme concentration after $2 \mathrm{~s}$ is 0.75 of the maximum value after refreshment.

The enzyme concentration in the capillary without refreshment is calculated from equation [5.42] and the result of the calculation is presented in figure 5.23. In this case the equilibrium is realized after less than $1 \mathrm{~s}$. The enzyme concentration at the surface of the capillary however is in an order of magnitude of $4.5 \times 10^{-10} \mathrm{~mol}$. So it can be concluded that the maximum enzyme concentration in the capillary with refreshment is 100 times higher than in a capillary without refreshment. The dimensionless enzyme concentration at the surface of the capillary without refreshment is $6.7 \times 10^{-3}$ so less than $1 \%$ of the maximum surface concentration has been realized. A rapid refreshment of the capillary liquid during the adsorption is needed to prevent the undesired low surface concentration in that case. 


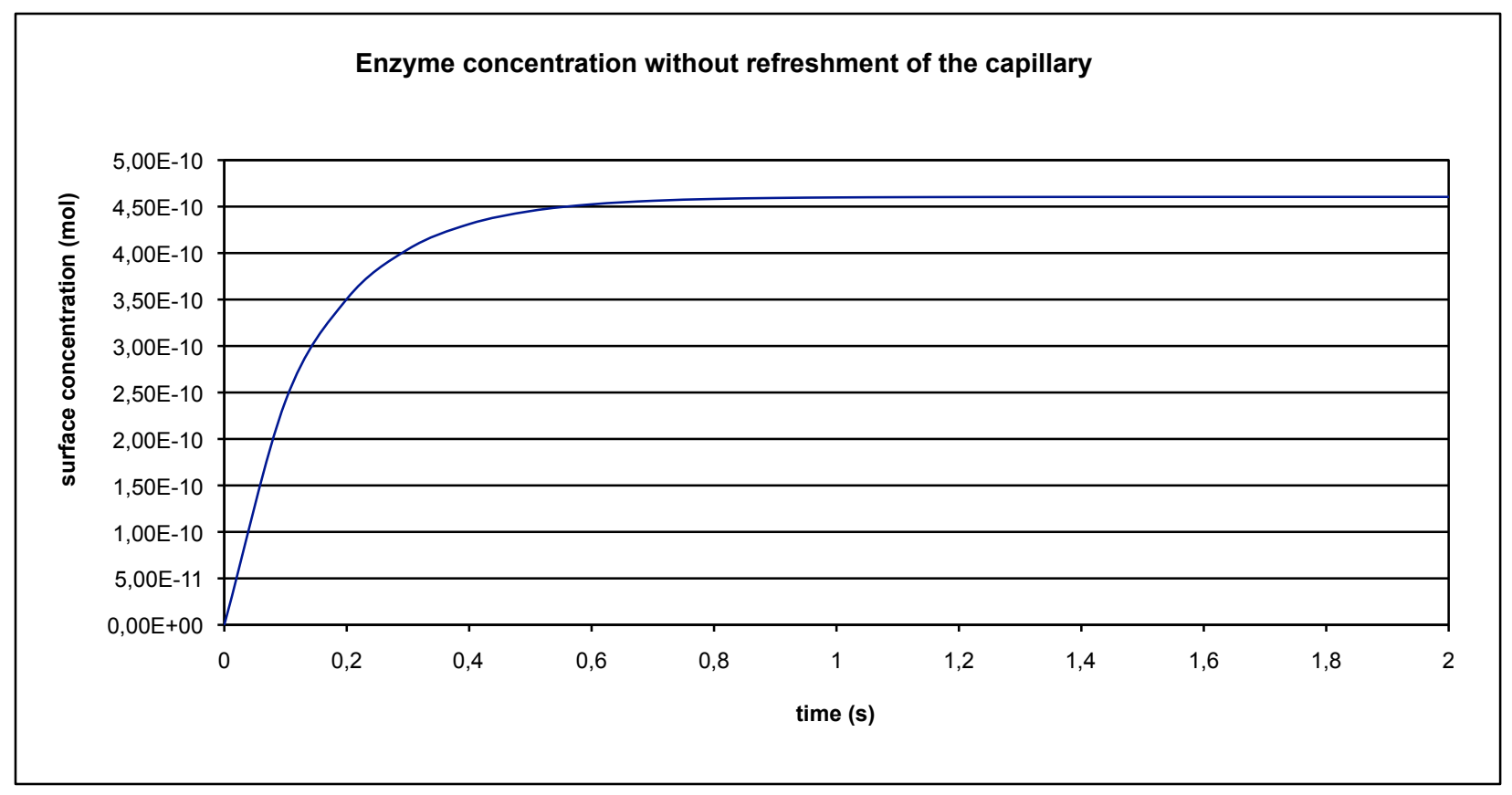

Figure 5.23: Model calculations for the adsorption dynamics of enzymes at a surface according to equation [5.42]

This refreshment can be realized by squeezing due to the mechanical energy. So the role of the mechanical energy is speeding up the transfer of enzyme molecules to the pores of the fabrics and to prevent suboptimal adsorption due to exhaustion of the capillary liquid.

\subsection{The application of ultrasound}

It is known that ultrasound can accelerate wet textile processes to a large extent [Moholkar et al., 2004]. This phenomenon is based on the mechanism of acoustic cavitation. The ultrasonic wave creates during its rarefaction period locally tiny bubbles, which collapse during the compression phase. These collapses create micro liquid jets that can penetrate deeply into the pores of the fabrics. Therefore ultrasound can be seen as a source of mechanical energy to accelerate the mass transfer processes in the pores of fabrics. It has been found that ultrasound also accelerates the performance of enzymes in enzymatic textile treatment processes [Agrawal et al. $2007 \&$ 2010]. Figure 5.24 shows the results of some of these experiments. The percentage pectin removal that is presented on the $\mathrm{Y}$-axis is the difference between the results of two identical treatments of a fabric. One treatment is done with the use of ultrasound and one treatment without the application of ultrasound. The difference in performance is expressed in $\Delta$ $\%$ pectin removal. 


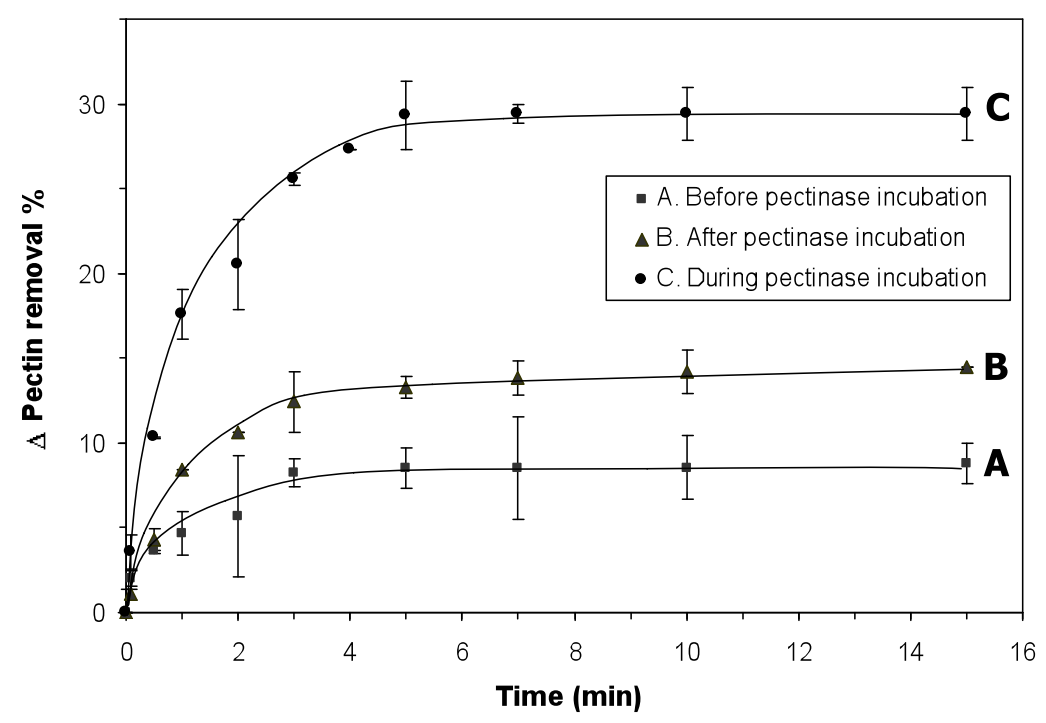

Figure 5.24: Experimentally determined effect of ultrasound on the performance of enzymes [Agrawal et al., 2010]

The case was to see the effect of ultrasound on the removal of pectin by the enzyme pectinase. Three experiments have been performed: ultrasound applied before, after and during the enzymatic treatment. From the figure it is clear that applying ultrasound before the enzymatic treatment did not affect the enzymatic performance. Applying ultrasound after the enzymatic treatment led to a better performance. The improved performance is explained in terms of sonomechanics and sono-chemistry. Sono-mechanics is the improved performance that is caused by mass transfer intensification when ultra-sound is applied. Sono-chemistry is the effect of ultrasound that is realized due to improved chemical reaction. Agrawal found in his work that the use of ultrasound has a positive effect when it is applied during incubation and rinsing [Agrawal et al. 2010]. During incubation it is noticed that a substantial improvement of the enzymatic performance occurs. Two effects induce the improvement of the performance. First effect is the improved mass transfer of enzymes into the substrate so-called sono-mechanics. Here the ultrasound treatment produces micro jets on the cotton fibre surface and may cause opening of the pores for a quicker migration of the enzyme molecules. The ultrasound treatment after incubation gives a moderate performance improvement. Second effect is the improved enzymatic reaction, the so-called sono-chemistry. To verify the sono-chemistry effect experiments have been done in a homogeneous system in which mass transfer does not play a role. The system studied consisted of poly-D-galacturonic acid as model substrate and pectinase as enzyme. It has been shown that ultrasound leads to an improvement of the enzymatic performance in the system. As here is no mass transfer the improvement can only be ascribed to an effect on the chemical reaction. Applying ultrasound during the enzymatic incubation resulted in a large effect on the performance. So besides a fast transfer of the enzymes to the capillary liquid, a fast refreshment of the capillary liquid during the adsorption of enzymes at the surface of the capillary wall and a fast removal of the reaction products ultra sound also 
improves the chemical reaction as such. Therefore ultrasound can be seen as a very effective and efficient way to apply mechanical energy to enzymatic treatment of textiles.

To apply ultrasound in textile industry it is necessary to invest in the installed base. It can be argued that ultrasound application on an industrial level is effective when it is applied in a rinsing compartment near the fabric guiding rollers in the rinsing liquid. Research is necessary to study the enhanced mass transfer on full width continuous treatment equipment. The application of ultrasound on pre-treatment installed base requires capital investment. This investment is not in line with the prior condition of this work that the new developed process has to be applied on existing continuous installed base without substantial adjustments and thus no capital investment. Therefore this application is no subject of further research in this work.

\subsection{Conclusion}

In this chapter a release model is derived, which shows the dominating effect of mechanical energy in bio-catalytic wet-textile processes. The effect of mechanical energy on the release of enzymes from a fabric to a bulk solution is studied. It is clear that not only a increases with increasing mechanical energy. Also the Pe-number increases in that case. It can be argued that squeezing, i.e. twisting and de-twisting, leads to changes in the location of the stagnant zone. This means that in -at least a part- of the fabric the stagnant and convective zone alternate. This has the effect that the volume of the convective layer increases. The increase of the convective zone leads to an increase in the convective mass transfer, resulting in an increased Pe-number. So application of mechanical energy enhances the mass transfer from the convective region to the bulk, but also enhances the mass transfer from the diffusive to the convective zone.

The advantage of bio-catalytic wet-textile processes compared to conventional processes is the drastic reduction of process temperatures. The chemicals that are used in conventional processes are significantly smaller than the ones that are used in enzymatic processes. The decreasing reaction temperature and the increasing molecular size of the chemicals in the case of enzymatic processes result in reduced mass transfer over time. So for successful implementation of enzymatic wet-textile processes it is necessary to compensate the reduced mass transfer. The enzyme kinetics in combination with the induced mass transfer by mechanical energy is the basis for successful implementation of enzymatic wet-textile processes. Induced mass transfer is the key to the necessary refreshment of the volume of the capillaries of the yarn to realize sufficient enzyme-substrate complex forming. This means that it is necessary for lab and pilot scale experiments to acknowledge the importance of mass transfer when enzymatic experiments are evaluated. This conclusion underlines the importance of mass transfer for successful upgrading of bio-catalytic processes from lab scale to industrial scale processes. 


\section{References}

Agrawal, P., 'The performance of cutinase and pectinase in cotton scouring", ISBN 90-365-22439, Thesis University of Twente, the Netherlands, 2005

Agrawal, P.B., V.A. Nierstrasz, M.M.C.G. Warmoeskerken and M. van der Veer, "Apparatus for enzymatic and ultrasound treatment of textiles and method of treatment thereof", Patent GB 2432585, 2007

Agrawal, P., V.A. Nierstrasz and M.M.C.G. Warmoeskerken, "The role of mechanical action in low-temperature cotton scouring with F.solani pisi cutinase and pectate lyase", Enzyme and Microbial Technology, Volume 42, p 473 - 482, 2008

Agrawal, P., V.A. Nierstrasz and M.M.C.G. Warmoeskerken, "Ultra sound boosted enzymatic cotton scouring process with cutinase and pectate lyase", Journal of Biocatalysis and Biotransformation, accepted 2010.

Benninger, home page, last time visited on Mai, $18^{\text {th }}, 2010$, www.benninger.ch

Bouwhuis, G.H., B. Dorgelo and M.M.C.G. Warmoeskerken, "Textile pretreatment process based on enzymes, catalyst and ultrasound", Melliand International, Volume 4, p150-p151, 2009.

Donck, van der, J.C.J, A. So and G. Frens, "The influence of stretching on salt release from porous yarns", Tenside, surfactants, detergents, Volume 35, p 119 - 122, 1998

Moholkar, V.S., M.M.C.G. Warmoeskerken, C.D. Ohl and A. Prosperetti, "Mechanism of masstransfer enhancement in textiles by ultrasound", American Institute of Chemical Engineers Journal, Volume 50, p.58-64, 2004

Nierstrasz, V.A., and M.M.C.G. Warmoeskerken, "Textile processing with enzymes", (CavacoPaulo A., and Guebitz, G.M., Eds), ISBN 1855736101 Woodhead Publishing, 2003

ProteinDataBank, home page, last time visited on Mai $9^{\text {th }}, 2010$, www:pdb.org

Rouette, H.K., "Encyclopedia of Textile Finishing”, ISBN 3-540-65031-8, Springer Verlag Berlin/Germany, 2001

Warmoeskerken M.M.C.G., P. van der Vlist, V.S. Molholkar and V.A. Nierstrasz, "Laundry process intensification by ultrasound", Colloids and surfaces, A: Physiochemical and Engineering Aspects, 210(2-3) p 277 - 285, 2002

Warmoeskerken M.M.C.G. and R.M. Boom, " $90^{\text {th }}$ Annual meeting and Expo, May 9-12, Orlando, USA, 1999 


\section{Industrial Experiments}

Lab and pilot scale experiments have been used to design the new pre-treatment process for cotton. The industrial experiments are done at Satta e Bottelli, which is an Italian textile finishing company. Their standard pre-treatment process can be characterized as a pad batch - hot bleach pre-treatment process. In the new designed process the pre-treatment steps desizing and scouring are done with the enzyme cocktail. For the bleaching step the manganese catalyst is finally used for the activation of hydrogen peroxide in low alkaline conditions. Evaluation of the trials shows a good pre-treatment performance for desizing and hydrophilicity, while a slight decrease of whiteness, caused by reduced concentration of hydrogenperoxide, is measured. A substantial reduction of the pollution load of the wastewater and a reduction of the consumption of water and energy is realized. The quality of the fabric in terms of bleaching damage is better than standard. 


\subsection{Introduction}

The aim of this work is the development of a new Industrial pre-treatment process. In the previous chapters the enzyme cocktail, bleaching agents and the influence of mechanical energy in the pre-treatment process have been discussed. The next step in the development strategy is the upgrading of lab-scale experiments via pilot scale to industrial scale. The major difference between lab and industrial scale is the equipment that is used. Industrial equipment is designed and optimized for conventional pre-treatment processes. These processes and the optimization are often realized by trial and error. To implement bio-catalytic pre-treatment on industrial scale is not only a novelty in terms of the new chemistry that is used. The goal of the new pretreatment process is to realize a substantial reduction of water, energy and wastewater. Therefore industrial trials are crucial. This leads to the necessity of large scale testing on the production location. It is often seen that, in the transition from lab-scale to industrial scale processing, unexpected problems occur. These problems can mostly be addressed to the differences in equipment and process conditions. In Chapter 5 the importance of the interaction between chemistry, fabric and equipment have been described. There it has been postulated that for a successful implementation of new processes the understanding of the three basic elements in textile treatment, chemistry, fabric and equipment are indissoluble.

\subsection{Up-scaling process}

The start of the development process is mostly on lab scale. Here the products and processes are tested an all required aspects. These facilities are often centralized and far away from the hectic production departments. After finalizing the lab research the development is tested and optimized on pilot scale. On pilot scale the industrial level conditions are mimicked. The major advantage of pilot scale experiments is that implementation on industrial level is faster and less optimization experiments are needed. Finally the approved pilot scale tests are upgraded to industrial level.

The lab work here has been done using beakers, a foulard and a climate chamber for reaction time. The pilot scale experiments have been done by TanatexChemicals in Ede in the Netherlands for specific application on customer level. In fact the equipment that has been used there is the same, but on a lager scale. Here it was also not possible to mimic fully the industrial processing conditions. The advantage of the pilot scale experiments is that the results and the know-how enable the specialists to predict the result on specific customers equipment and conditions. So the added value here is the translation of pilot scale experiments to industrial scale experiments for specific installed base and process conditions. The translation from pilot scale to industrial scale is more difficult compared to conventional treatment due to the molecular size of the enzymes. This difference is expressed in a lower diffusivity and consequently a slower mass transfer of the enzyme as shown in chapter 5 . After the pilot scale experiments the industrial experiments are defined. Industrial pre-treatment experiments are carried out at the company Satta e Bottelli, which is located in Nerviano in Italy.

In chapter 3 it is concluded that desizing and scouring can be done with an enzyme cocktail containing amylase, cutinase and pectinase. The impregnation temperature is $50^{\circ} \mathrm{C}$ and the rinsing temperature is $30^{\circ} \mathrm{C}$. In figure 6.1 the new pre-treatment process on the lab scale is 
schematically drawn. In the same scheme the standard Satta e Bottelli pad batch - hot bleach process and the proposed pre-treatment process have been drawn. A significant difference between lab scale experiments and industrial trials is the temperature during the bleaching reaction. This difference is caused by technical restrictions of the installed base. It is not possible to control the temperature in the bleaching steamer. In the steamer $100 \%$ relative humidity is required at $100^{\circ} \mathrm{C}$. Reducing the steamer temperature increases the risk of condensation of water and thus increasing the risk of water spots on the fabric. It is expected that these water spots can lead to stains in the fabric after dyeing. To avoid this risk it was decided to operate the steamer at $100^{\circ} \mathrm{C}$.
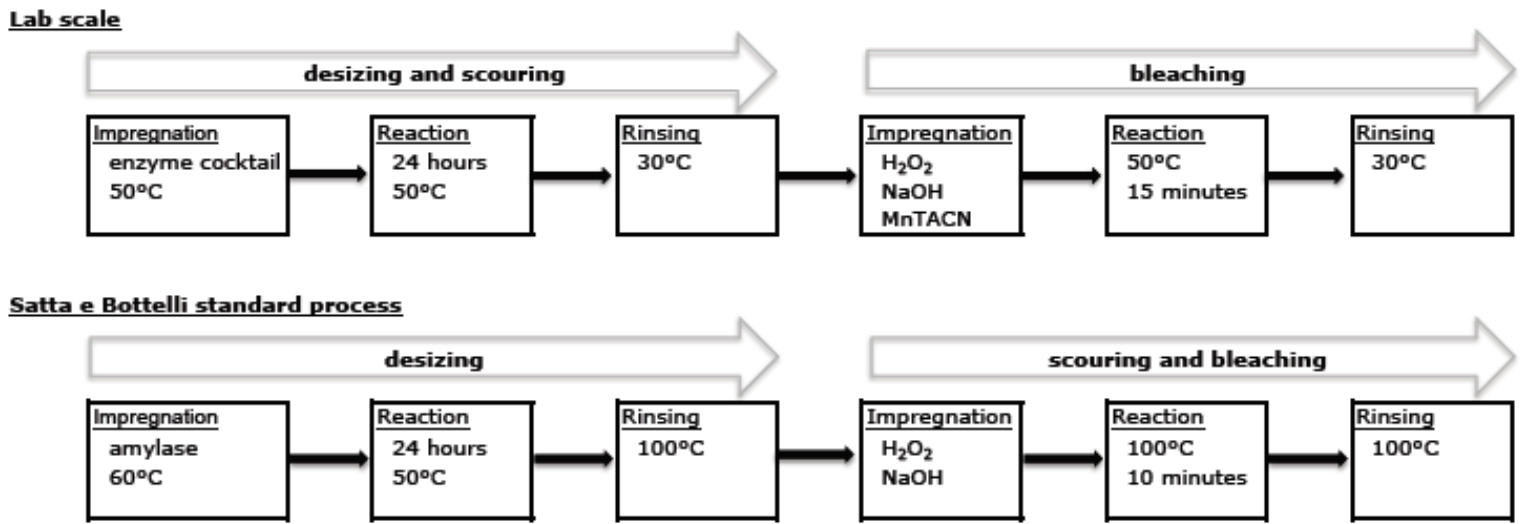

Industrial trial

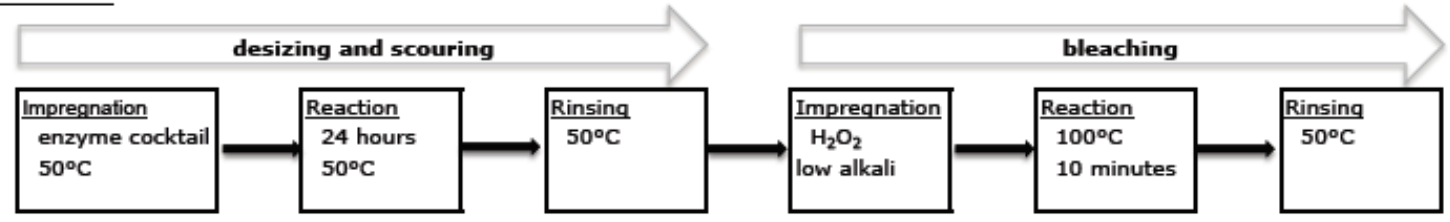

Figure 6.1: Schematic overview of the pre-treatment experiments at lab and industrial scale and standard treatment

\subsection{Satta e Bottelli}

Satta e Bottelli is a textile finishing company that has been founded in 1921. Since 1987 it is a subsidiary of the Tessival Group. The company is a textile finisher of cotton, linen and mixtures mainly for the household market. A small part of the production capacity is used for other markets as garments, decoration and interior products. A small part of the production volume is on commission basis. The production process consists of three departments, a pre-treatment, dyeing and finishing department. In the pre-treatment department the fabric is singed, desized, scoured and bleached. Here the fabric can be pre-treated on full width and in rope from. A substantial part of the production volume is also mercerised. The second department is the dyeing house, where the fabrics are coloured. The third department is the finishing department. Here the fabric gets the required properties. The production volume at Satta e Bottelli is on a weekly basis 600.000 running meter fabrics. About 200.000 meter per week is pre-treated on full 
width, the rest of the production volume is pre-treated in rope form. Pre-treatment of cotton in rope form is no subject of research as described before. The company has 140 employees.

In the pre-treatment department the full width fabric is pre-treated according the pad batch - hot bleach process. The pad batch - hot bleach pre-treatment equipment has been drawn schematically in figure 6.2 .

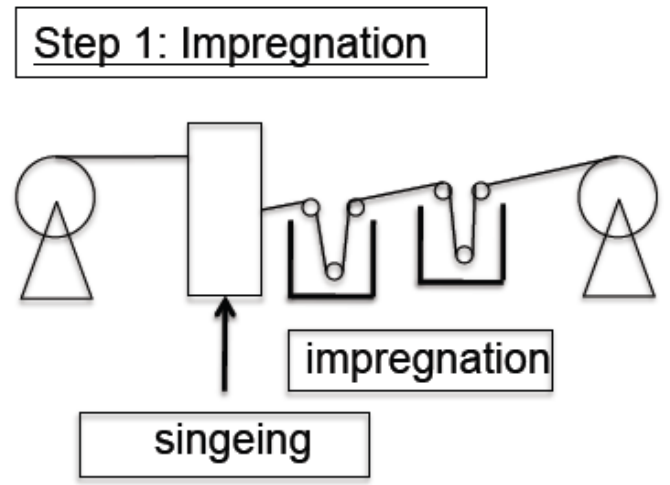

\section{Step 2: Rinsing-bleaching-rinsing}

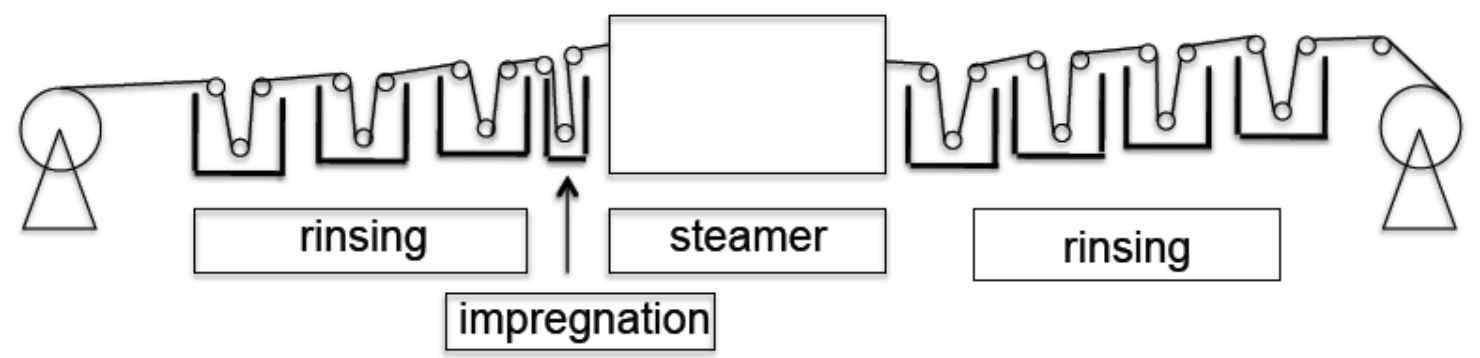

Figure 6.2: Schematic drawing of the Satta e Bottelli pad batch - hot bleach equipment

In step 1 the fabric is singed, immediately followed by impregnation. The impregnation of the fabric takes place in two impregnation units. The impregnation liquor is added to the last unit and flows in contra-flow to the first unit. The impregnation unit is temperature controlled. After impregnation the fabric is stored at room temperature (RT) for several hours to enhance the desired reaction. In step 2 the fabric is rinsed in 3 rinsing units. The rinsing water runs in contraflow from the third to the first rinsing compartment. The rinsing temperature is controlled and the rinsing water supply is dosed in litre water per kilogram treated fabric. After rinsing the fabric is guided into the Flex-nip, which is an impregnation unit. Here the bleaching agents are added on the fabric. The wet pick-up here is almost $100 \%$. The extra pick-up is possible due to the high quantity of liquor that is retained in the free volume of the fabric [Rouette, 2001]. The bleaching agents are dosed in $\mathrm{ml} / \mathrm{l}$ bleaching liquor. In the Flex-nip the bleaching agents are added to the 
fabric and the wet pick-up is controlled. The ratio of the bleaching agents in the flex nip is preset according to table 6.1 'bleaching agents'. In the Flex-nip it is possible to in- or decrease the concentration bleaching chemicals in the same proportion. This change of concentration, where the bleaching agents still are mixed in the same proportion, is called the reinforcement factor. By altering the reinforcement factor the concentration of the added bleaching liquid can be varied. After impregnation the fabric is lead into the steamer where the bleaching reaction takes place. The fabric is rinsed in four rinsing compartments after bleaching. These compartments are temperature controlled. The rinsing water is added to the last rinsing compartment and flows in contra-flow from the last rinsing unit to the first. The water dosage is in litre rinsing water per $\mathrm{kg}$ fabric. It is possible to dose acid in the last rinsing unit for acidification of the fabric. In that case the last unit is not used for rinsing.

The fabric is treated in open width form. The maximum width of the fabric is $3200 \mathrm{~mm}$ and the maximum fabric weight is about $500 \mathrm{~g} / \mathrm{m}^{2}$. The installed base is operational from 1993 and well maintained.

\subsubsection{Chemicals and conditions in industrial trials}

The industrial trials have been done with experimental Tanatex products, which have been prepared for these trials. The reason for this is the restriction to prepare and stabilize these products at the finishing plant of Satta e Bottelli. The fact that for the industrial experiments other products were used than in the lab makes mutual comparison rather complicated. The constituents of the impregnation bath for combined desizing and scouring and for bleaching are reported separately in $\mathrm{g} / \mathrm{l}$. The enzyme activity and the active content of the other bleaching agents are notified.

Desizing and scouring step

In Chapter 3 the chemicals and process conditions for pad batch - hot bleach are determined on lab scale. The chemicals that are used on lab scale are described in Chapter 3 in table 3.1. The enzyme amylase that has been used in lab scale experiments is for the industrial scale trials replaced by one with better $\mathrm{pH}$ performance in slight acidic environment. The reason for this is the expected better performance in combination with singeing, which will be discussed in section 6.3.3.

The products and concentrations that have been used in these trials are given in table 6.1. 


\begin{tabular}{|l|c|c|c|}
\hline \multicolumn{4}{|c|}{ Impregnation bath for combined desizing and scouring } \\
\hline Product & Reported Activity* & $\begin{array}{c}\text { Conc. used on industrial } \\
\text { scale }\end{array}$ & Conc. used on lab scale \\
\hline amylase & $65,000 \mathrm{TTAU} / \mathrm{g}$ & $1.5 \mathrm{~g} / \mathrm{l}$ & $4.0 \mathrm{~g} / \mathrm{l}$ \\
\hline cutinase & $15,000 \mathrm{LU} / \mathrm{g}$ & $4.0 \mathrm{~g} / \mathrm{l}$ & $1.5 \mathrm{~g} / \mathrm{l}$ \\
\hline pectinase & $3,000 \mathrm{APSU} / \mathrm{g}$ & $1.5 \mathrm{~g} / \mathrm{l}$ & $1.3 \mathrm{~g} / \mathrm{l}$ \\
\hline surfactant & $80 \%$ & $6.0 \mathrm{~g} / \mathrm{l}$ & $1.0 \mathrm{~g} / \mathrm{l}$ \\
\hline
\end{tabular}

Table 6.1: Comparison between the concentrations and products lab scale vs. industrial scale

* The supplier has determined the reported enzyme activity

All products that are used in the impregnation bath for combined desizing and scouring are supplied by TanatexChemicals in Ede/the Netherlands. The amylase in table 6.1 is the pure enzyme with the same activity as Tanazym LTC01. The enzyme cutinase is an experimental product. It is supplied via TanatexChemicals by Novozymes. The enzyme pectinase that is used is Bioprep 3000L. This is a commercially available Novozymes product. As surfactant the commercially available product Tanaterge Advance is used. This product is characterised as a fatty alcohol polyglycol ether.

The concentrations chemicals that are used on industrial scale are different from the concentrations that are used on lab scale. The reason for this is elucidated below:

- the concentration amylase is reduced because Tanatex has the experience at Satta e Bottelli that sufficient desizing properties are achieved with the amylase concentration that is used;

- the concentration cutinase is drastically increased for the industrial trial. The reason for this that it is decided here to proof the principle of the use of cutinase under the proposed treatment conditions. It is likely that here will be room for reduction of the concentration cutinase;

- premixing conditions at TanatexChemicals causes the difference in the concentration pectinase, between lab scale and industrial scale experiments. Here is some room for further optimization in the product formulation;

- the concentration surfactant is increased drastically. On lab scale the concentration of the surfactant is determined only for wetting properties. Satta e Bottelli fabrics can contain oilspots from the weaving machines. Therefore the standard Satta e Bottelli industrial concentration surfactant is used.

The composition for the enzyme cocktail was the same for all experiments. The wet pick-up after impregnation was $70-80 \%$ of the dry weight of the fabric. This is in line with the wet pick-up of the standard process.

\section{Bleaching step}

In chapter 4 the chemicals, their concentrations and process conditions for pad batch - hot bleach treatment of cotton are explored. Here two strategies have been followed. The first strategy is catalytic bleaching with the manganese catalyst. The second strategy is bleaching 
without the use of the catalyst and with a low concentration $\mathrm{NaOH}$. In table 6.2 the bleaching agents and the concentrations that are used for the lab scale strategies are compared with the initial concentrations bleaching agents that is used for the industrial trials. The industrial scale conditions cannot be mimicked adequately on lab scale due to restrictions of the available equipment and therefore lab scale experiments are not optimized.

\begin{tabular}{|c|c|c|c|}
\hline \multicolumn{4}{|c|}{ Impregnation bath for bleaching } \\
\hline Product & $\begin{array}{l}\text { Conc. used on } \\
\text { lab scale I }\end{array}$ & $\begin{array}{l}\text { Conc. used on } \\
\text { lab scale II }\end{array}$ & $\begin{array}{l}\text { Conc. used on } \\
\text { industrial scale }\end{array}$ \\
\hline $\mathrm{H}_{2} \mathrm{O}_{2} 35 \%$ & $10.0 \mathrm{ml} / \mathrm{l}$ & $10.0 \mathrm{ml} / \mathrm{l}$ & $35.0 \mathrm{ml} / \mathrm{l}$ \\
\hline $\mathrm{NaOH} 48^{\circ} \mathrm{Bé}$ & & $1.0 \mathrm{ml} / / \mathrm{l}$ & $1.0 \mathrm{ml} / \mathrm{l}$ \\
\hline stabilzer & $10.0 \mathrm{ml} / \mathrm{l}$ & $9.0 \mathrm{ml} / \mathrm{l}$ & $13.5 \mathrm{ml} / \mathrm{l}$ \\
\hline $\begin{array}{l}\text { manganese } \\
\text { catalyst }\end{array}$ & $6.0 \mu \mathrm{mol} / \mathrm{l}$ & - & - \\
\hline surfactant & $1.0 \mathrm{ml} / \mathrm{l}$ & $1.0 \mathrm{ml} / \mathrm{l}$ & $3.0 \mathrm{ml} / \mathrm{l}$ \\
\hline
\end{tabular}

Table 6.2: Comparison between the concentration and products used for bleaching experiments on lab scale bleaching and industrial trials

The bleaching agents and their concentrations that are used on lab scale are different from the concentrations and products that are used on industrial scale. The criteria to define the products and concentrations that are used on industrial scale, when compared with lab scale are:

- two strategies for bleaching are followed on lab scale. One strategy with and one strategy without the use of manganese catalyst. For the Satta e Bottelli trials it is decided not to use the manganese catalyst due to restrictions of the installed base as mentioned before in this chapter. So on industrial scale low alkali bleaching is tested. Therefore comparison is appropriate between the bleaching agents and the concentrations that have been proposed for industrial scale and for lab scale II, table 6.2;

- the concentration $\mathrm{H}_{2} \mathrm{O}_{2}$ is drastically increased for the industrial trials, if compared with lab scale experiments. The reason for this is that on lab scale the bleaching experiments are used to proof the principle and not to achieve a specific whiteness value. The whiteness standard of Satta $\mathrm{e}$ Bottelli is of a high level and to achieve this whiteness high concentrations $\mathrm{H}_{2} \mathrm{O}_{2}$ are required;

- the stabilizer, Tannex RL 1024A, that is used in these experiments is characterized as an alkaline solution of anorganic salts and organic sequestering agents. This product has good buffering properties. It is and experimental product;

- the concentration surfactant, Tanaterge Advance, is increased for the industrial trials to ensure good wetting and rinsing properties. The concentration surfactant is in line with the standard concentrations that are used by this finisher. The installed base is equipped with an automatic dosing system. This system doses volumetrically and therefore the concentrations chemicals are given in $\mathrm{ml} / \mathrm{l}$.

\section{Process conditions}

Lab scale experiments are carried out to proof the principle of bio-catalytic pre-treatment of cotton. On this scale the pad batch - hot bleach conditions are optimized in terms of temperature and time. The lab scale and industrial scale conditions are described in table 6.3. It 
is clear that due to equipment restrictions some adjustments are necessary. The major difference in the process conditions is the steamer-temperature during the reaction of the bleaching agent. It was not possible to reduce the temperature in the steamer without capital investment. Consequence of this restriction is that the manganese catalyst cannot be applied as it is not stable above $40^{\circ} \mathrm{C}$. The rinsing after the enzymatic treatment is carried out at higher temperature in industrial trials than at lab scale experiments. The reason for this is that here the rinsing water supply is connected to the heat exchanger. The heat exchanger increases the water temperature up to $50^{\circ} \mathrm{C}$. The rinsing temperature after bleaching is set at $50^{\circ} \mathrm{C}$ in the first rinsing compartment. At this temperature Tanaterge Advance shows good emulsifying properties.

\begin{tabular}{|l|c|c|}
\hline Process conditions & Lab & Industry \\
\hline $\begin{array}{l}\text { Impregnation (enzymes) } \\
\text { bath } \\
\text { - temperature }\end{array}$ & $50^{\circ} \mathrm{C}$ & $60^{\circ} \mathrm{C}$ \\
- pH & 8 & $8 \rightarrow 6,5^{*}$ \\
fabric velocity & - & $70-80 \mathrm{~m} /$ minute \\
\hline $\begin{array}{l}\text { Reaction (enzymes) } \\
\text { time } \\
\text { temperature }\end{array}$ & $16 \mathrm{hr}$ & $16-24 \mathrm{hr}$ \\
\hline $\begin{array}{l}\text { Rinsing } \\
\text { water quality }\end{array}$ & $50^{\circ} \mathrm{C}$ & $50^{\circ} \mathrm{C}^{* *}$ \\
$\begin{array}{l}\text { temperature } \\
\text { water usage } \\
\text { fabric velocity }\end{array}$ & distilled water & demineralised \\
\hline $\begin{array}{l}\text { Impregnation (bleach) } \\
\text { temperature }\end{array}$ & $30^{\circ} \mathrm{C}$ & $50^{\circ} \mathrm{C}$ \\
pH & beaker; LCR $1: 100$ & $6 \mathrm{l} / \mathrm{kg} \mathrm{fabric}$ \\
\hline $\begin{array}{l}\text { Reaction (bleach) } \\
\text { temperature } \\
\text { time }\end{array}$ & - & $40-50 \mathrm{~m} / \mathrm{minute}$ \\
\hline Rinsing & $50^{\circ} \mathrm{C}$ & $\mathrm{RT}$ \\
water quality & 10.5 & 10,5 \\
temperature & $50^{\circ} \mathrm{C}$ & $100^{\circ} \mathrm{C}$ \\
water usage & 15 minutes & 10 minutes \\
\hline
\end{tabular}

Table 6.3: Overview of lab scale and industrial scale conditions at Satta e Bottelli

* At the start of the impregnation for desizing and scouring the $\mathrm{pH}$ of the bath is $\mathrm{pH}$ 8. During the treatment the $\mathrm{pH}$ drops gradually to $\mathrm{pH}$ 6.5. This phenomenon is explained in $\S 6.5 .1$.

** During the reaction the fabric is stored without heating on an A-frame. The temperature of the impregnated fabric on the A-frame decreases from a temperature of $60^{\circ} \mathrm{C}$ to $50^{\circ} \mathrm{C}$ after 16 hours

*** The fabric velocity is in the successive process steps equal to the velocity in the first rinsing compartments.

All the bleaching agents that have been used in these trials are supplied by TanatexChemicals, except $\mathrm{H}_{2} \mathrm{O}_{2}$ and $\mathrm{NaOH}$ that are supplied by local traders.

\subsubsection{Fabric for trials}

During industrial tests in total $12.000 \mathrm{~m}$ fabric is treated, divided over three different substrates. The data of the substrates are given in table 6.4. 


\begin{tabular}{|l|c|c|c|}
\hline & Fabric 1 & Fabric 2 & Fabric 3 \\
\hline Name & Tov.Fiocco Cotone & Tela Cotone & Percale Savoy \\
\hline Composition & $100 \%$ Co & $100 \%$ Co & $100 \%$ Co \\
\hline Construction & Jacquard & $30 / 30 \times$ & $100 / 2 \times 80 / 2$ \\
& & $30 / 30$ & \\
\hline Fabric weight $\mathbf{( g / \mathbf { m } ^ { 2 }}$ ) & 199 & 129 & $120^{*}$ \\
\hline Total length in $\mathbf{m}$ & 2000 & 6000 & 4000 \\
\hline Fabric width in cm & 200 & 316 & $305^{\star}$ \\
\hline
\end{tabular}

Table 6.4: Data of the substrates from Satta e Bottelli

* The average value of two percale fabrics is reported here.

Fabric 1 is treated according the instructions for chemicals, concentrations and process conditions as they are described in the previous section. Fabric 1 is impregnated with the enzyme cocktail. After impregnation the fabric is stored for 16 hours to enable the enzymatic reaction. The fabric is rinsed after storage, followed by impregnation with the bleaching agents. In the steamer the reaction of bleaching agents takes place, followed by a rinsing process step. This procedure with enzymes and bleach system has also been applied to the fabric 2 and 3 .

\subsection{Evaluation techniques}

The samples of the different trials have been evaluated. The evaluation is done with the use of the following performance indicators:

\section{Degree of whiteness}

The degree of whiteness is measured using photo-spectroscopy. Here the CIE/lab value is reported. This evaluation technique is described in Chapter 4.

\section{Indication of damage}

The cotton fibre is damaged during the pre-treatment process. It is therefore necessary to evaluate this process in terms of fibre damage. The performance indicators for the fibre damage are:

- DP-value;

- S-factor.

The average degree of polymerisation expresses the number of glucosidic monomers that form the polymer. The cuprammonium fluidity $(F)$ is studied under standard conditions before and after the bleaching process. The degree of polymerisation is calculated using the equation:

$$
D P=2032\left(\log \frac{74.35+F}{F}\right)-573
$$

The fibre damage is also expressed as the damage factor $(S)$. This factor relates damage to the change of DP, where the initial DP of the untreated cotton is taken into account. The damage factor $S$ is calculated using the equation: 
$S=\frac{\log \left(\frac{2000}{D P}-\frac{2000}{D P_{0}}+1\right)}{\log 2}$

in which:

$\mathrm{DP}$ is degree of polymerisation of the treated fabric and $\mathrm{DP}_{0}$ is the degree of polymerisation of the untreated fabric.

\section{Desizing value}

For evaluation of the desizing performance the TEGEWA-violet scale method is used. This method is described in Chapter 3.

Hydrophilicity of the fabric

Hydrophilicity of the fabric is measured to evaluate the water pick-up aspects of the fabric. Here the drop life time and the migration of the water drop in the fabric is evaluated and is expressed in $\mathrm{s}$ respective in $\mathrm{mm}$. See also Chapter 3 .

\section{Pectin content}

The pectin content is measured as the performance indicator for pectin removal after treatment. This test is also called the Ruthenium red test, where the colour strength of the dyed treated sample is compared with the dyed untreated sample. Using Kubelka-Munk equation the residual percentage pectin (\% vs. greige 100\%) is calculated. See also Chapter 3.

\section{Other performance indicators}

Other performance indicators that are evaluated are $\mathrm{pH}$, hardness, petrol-ether extraction for residual hydrophobic matter and methanol extraction for residual water-soluble matter. These indicators are within or better than industrial accepted values. The hardness of the fabric, expressed in $\mathrm{mgr} \mathrm{CaO}$ per $\mathrm{kg}$ fabric is sometimes beyond industrial accepted values. This is not surprisingly as there is no sequestering agent used in the trials.

\subsection{Trials at Satta e Bottelli}

For the trials at Satta e Bottelli the fabrics Tov Fiocco Cotone, Tela Cotone and Percale are treated with pre-treatment agents that have been described in section 6.3 'chemicals and conditions'. Shortly after the start of the trials it has been concluded that activation of $\mathrm{H}_{2} \mathrm{O}_{2}$ was insufficient. Poor whiteness of the fabric confirms this conclusion. To improve the whiteness of the fabric changes in the concentrations of the bleaching agents have been carried out during production:

1. the concentration stabilizer is reduced from $15 \mathrm{ml} / /$ to $10 \mathrm{ml} / \mathrm{l}$ in trial 2 . It has been expected that the reduction of the bleaching stabilizer would improve the decomposition of $\mathrm{H}_{2} \mathrm{O}_{2}$ and 
therewith improve the whiteness of the fabric. After changing the concentration it has been concluded that further improvement was required;

2. in trial 3 the concentration surfactant is increased from 3 to $4 \mathrm{ml} / \mathrm{l}$ to improve the rinsing performance after bleaching;

3. the quantity $\mathrm{NaOH} 48^{\circ}$ Bé is increased in trial 4 from $0 \mathrm{ml} / \mathrm{l}$ to $5 \mathrm{ml} / \mathrm{l}$. This is done to activate the decomposition of $\mathrm{H}_{2} \mathrm{O}_{2}$;

4. in trial 5 the concentration $\mathrm{NaOH}$ is further increased to $8 \mathrm{ml} / \mathrm{l}$ in the bleaching liquor;

5. in trial 6 the concentration $\mathrm{NaOH}$ is further increased to $10 \mathrm{ml} / \mathrm{l}$ in the bleaching liquor;

6. finally in trial 7 the concentration $\mathrm{H}_{2} \mathrm{O}_{2}$ is increased from 35 to $40 \mathrm{ml} / \mathrm{l}$ in the bleaching liquid.

From every trial fabric samples taken and tested. The samples taken during the trials are compared to standard production fabrics.

An overview of the chemical concentrations that are used in different trials is listed in table 6.5. The chemical concentrations at the start of the trials are listed in column 'trial 1'. The adjustments are listed in trial 2 to 7 in table 6.5 .

\begin{tabular}{|c|c|c|c|c|c|c|c|}
\hline Trial & 1 & 2 & 3 & 4 & 5 & 6 & 7 \\
\hline \multicolumn{8}{|l|}{ Pad batch BioScouring: } \\
\hline amylase in $\mathrm{g} / \mathrm{l}$ & 1.5 & 1.5 & 1.5 & 1.5 & 1.5 & 1.5 & 1.5 \\
\hline cutinase in $\mathrm{g} / \mathrm{l}$ & 4.0 & 4.0 & 4.0 & 4.0 & 4.0 & 4.0 & 4.0 \\
\hline pectinase in $\mathrm{g} / \mathrm{l}$ & 1.5 & 1.5 & 1.5 & 1.5 & 1.5 & 1.5 & 1.5 \\
\hline surfactant in $\mathrm{g} / \mathrm{l}$ & 6.0 & 6.0 & 6.0 & 6.0 & 6.0 & 6.0 & 6.0 \\
\hline \multicolumn{8}{|l|}{ Pad steam bleaching: } \\
\hline $\mathrm{H}_{2} \mathrm{O}_{2} 35 \%$ (ml// bleaching liquor) & 35 & 35 & 35 & 35 & 35 & 35 & 40 \\
\hline $\mathrm{NaOH} 48^{\circ} \mathrm{Be}$ (ml/l bleaching liquor) & - & - & - & 5 & 8 & 10 & 10 \\
\hline stabilizer & 15 & 10 & 10 & 10 & 10 & 10 & 10 \\
\hline surfactant & 3 & 3 & 4 & 4 & 3 & 4 & 4 \\
\hline
\end{tabular}

Table 6.5: Adjustments to chemical concentrations due to poor whiteness

The numbers of the samples in the evaluation report correspond with the sample numbers as described before. The samples of trial 6 could not be definitely addressed to this trial and therefore they are not reported.

\subsubsection{Observations during the trials}

Impregnation with the enzyme cocktail

The enzyme cocktail is prepared as described in table 6.1 The $\mathrm{pH}$ of the impregnation bath is $\mathrm{pH}$ 8.4 at the start of the production. During processing the $\mathrm{pH}$ decreases from $\mathrm{pH} 8,4$ to $\mathrm{pH} 6.4$, which is shown in figure 6.3. It is believed that singeing dust, which has an acidic buffering effect, causes this. The reason for the acidic buffering effect of the impregnation bath is the burning of cellulose during singeing. During the burning of cellulose $\mathrm{CO}_{2}$ is formed as reactant resulting in the decrease of the $\mathrm{pH}$ of the enzyme solution. After 1.5 hour, of the total production time of 3 hours, the final $\mathrm{pH}$ of the impregnation bath was realized at $\mathrm{pH} 6.4$. The phenomenon of $\mathrm{pH}$ decrease is well known in pre-treatment processes. Therefore an amylase with better performance is neutral to slight acidic environment is used. So here Tanazym LTC 01 replaces 
the amylase Baylase RL 987. The fabric is impregnated at a running speed of $80 \mathrm{~m} / \mathrm{minute}$. The impregnation unit contains per unit about 12 meters fabric. This results in an impregnation time of 0.3 minutes. Due to this relatively short penetration time the mechanical energy in this unit is important as described in chapter 5.

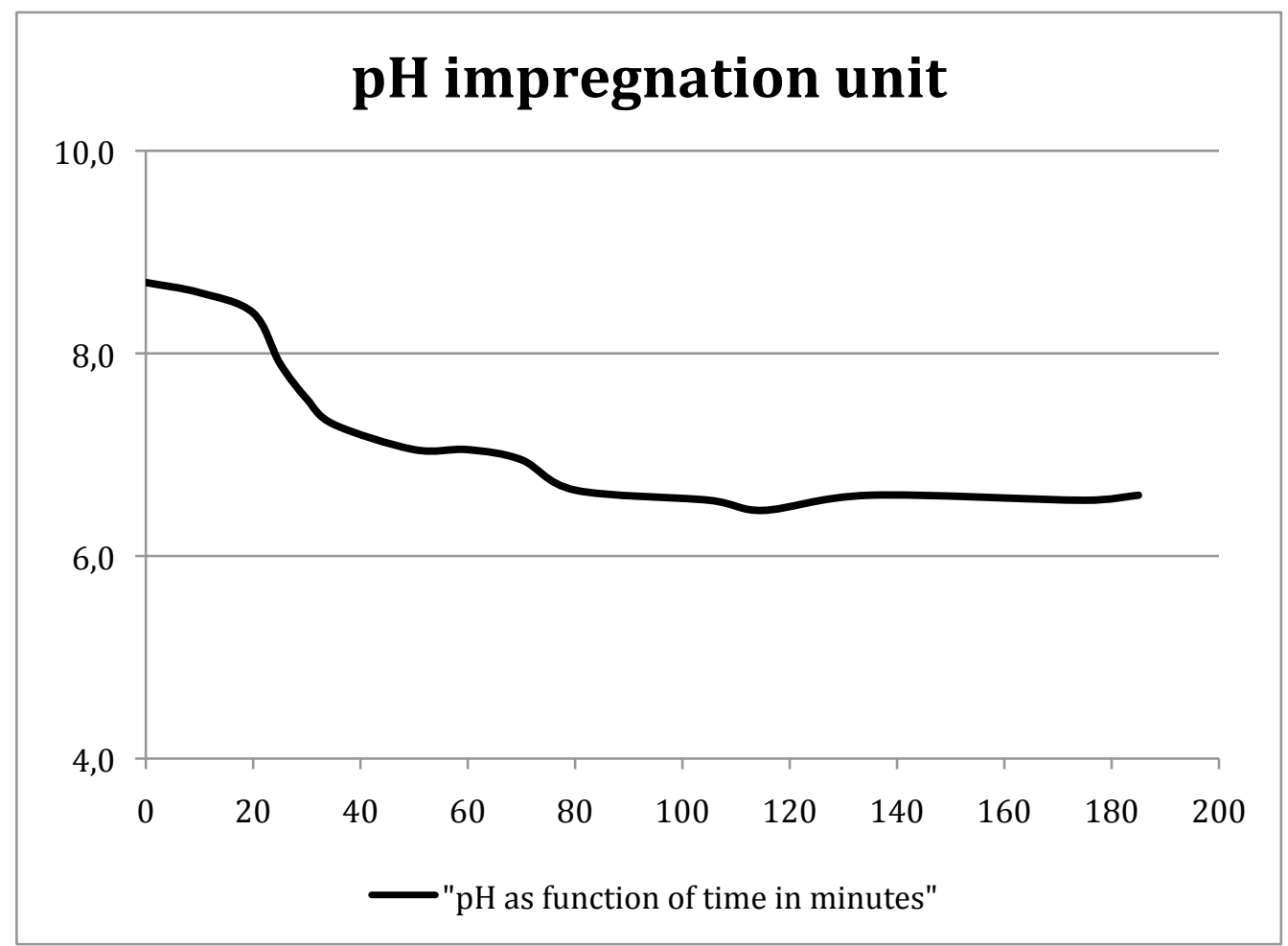

Figure 6.3: $\mathrm{pH}$ development during the padding after singeing as a function of time

Reaction time after impregnation with the enzyme cocktail

After impregnation with the enzymes the fabric is stored at RT on an A-frame for the enzymatic reaction. Overnight during storage the temperature of the fabric on the A-frame dropped with $10^{\circ} \mathrm{C}$ from the impregnation temperature to finally $50^{\circ} \mathrm{C}$ after 16 hours storage.

Rinsing after the enzymatic treatment

The temperature and $\mathrm{pH}$ of the rinsing bathes have been controlled. The temperature of the rinsing bathes was in the range of $45-56^{\circ} \mathrm{C}$ and the $\mathrm{pH}$ varied from 7 to 8.3 . These variations are within industrial acceptable margins for these processes.

Impregnation with bleaching agents

At the start of the experiments the $\mathrm{pH}$ of the bleaching liquor was 10.6 and the temperature was around $20^{\circ} \mathrm{C}$. During the trials a number of adjustments of the concentrations bleaching agents are carried out. These adjustments are shown in table 6.5. 


\section{Rinsing after bleaching}

The fabric is rinsed after the bleaching-reaction. The rinsing bath is controlled on the presence of residual $\mathrm{H}_{2} \mathrm{O}_{2}$ by manually spraying titanylchlorite on the fabric immediately after the fabric leaves the steamer. Orange staining after spraying titanylchlorite indicates the presence of residual peroxide and thus either inefficient use of bleaching agents or insufficient whiteness. This poor bleaching was confirmed when the dried pre-treated fabric was compared with the standard production. The temperature and $\mathrm{pH}$ of the liquor in the first rinsing compartment after the steamer were $50-60^{\circ} \mathrm{C}$ respectively $\mathrm{pH} 10-11$, which is within accepted process variations. In the following rinsing compartments the water is not heated and thus the temperature of the rinsing water dropped gradually to $20^{\circ} \mathrm{C}$ in the last rinsing compartment.

\subsection{Evaluation of the trials}

\subsubsection{Fabric 1: Tov. Fiocco Cotone}

The following samples are collected and evaluated after treatment:

1. greige fabric Tov. Fiocco Cotone;

2. standard production;

3. trial 1 - beginning of batch;

4. trial 2.

The samples are after treatment collected and evaluated at Tanatex. The fabric Fiocco Cotone is treated in trial 1 and 2. The result is reported in table 6.6. The treated samples are compared with the greige fabric (sample 1) and the standard pre-treated fabric (sample 2).

\begin{tabular}{|l|c|c|c|c|}
\hline Fiocco Cotone & $\begin{array}{c}\text { greige } \\
\text { sample 1 }\end{array}$ & $\begin{array}{c}\text { standard } \\
\text { sample 2 }\end{array}$ & $\begin{array}{c}\text { trial 1 } \\
\text { sample 3 }\end{array}$ & $\begin{array}{c}\text { trial 2 } \\
\text { sample 4 }\end{array}$ \\
\hline Degree of whiteness (Cie/D65) & - & 80 & 55 & 62 \\
\hline -basic & - & 2269 & 2471 & 2563 \\
\hline Indication of damage & 2930 & 0.26 & 0.17 & 0.13 \\
\hline -DP-value & - & 9 & $6-7$ & 9 \\
-S-factor & starch & - & - & - \\
\hline Desizing & - & 3 & $<1$ & $<1$ \\
-TEGEWA-violet scale value & - & 28 & 26 & 22 \\
- PVA presence & - & 24 & 22 & 22 \\
\hline Hydrophilicity & - & & & \\
-Time (s) & & 39 & 32 & 29 \\
-Warp (mm) & 100 & & & \\
\hline Pectin content (Ruthenium red & & & & \\
test) & & & & \\
\hline - Colourstrength (\% vs. greige & $100 \%$ ) & & & \\
\hline
\end{tabular}

Table 6.6: Evaluation of the pre-treatment TOV Fiocco Cotone

The fabric 'Tov Fiocco Cotone' is used in the trials 1 and 2. After bleaching the fabric is tested for residual $\mathrm{H}_{2} \mathrm{O}_{2}$ by spraying titanyl-chlorite on the wet fabric. This is done after the fabric comes out of the bleach-steamer and before it enters the rinsing compartment. Orange staining by 
titanylchlorite indicates residual $\mathrm{H}_{2} \mathrm{O}_{2}$. To reduce the quantity not-decomposed $\mathrm{H}_{2} \mathrm{O}_{2}$, and thus to improve the whiteness of the fabric, it has been decided to reduce the quantity stabilizer from 15 to $10 \mathrm{ml} / \mathrm{l}$. This adjustment showed an improvement of the whiteness from 55 degrees to 60 and after realizing the equilibrium in the bleaching bath the measured whiteness was 62 . Although some improvement of the whiteness was realized it was still far from the whiteness of the standard for this fabric. The other performance indicators are in line with the standard or better. Samples 5-7 have been collected after rework. This evaluation is not reported here.

It is concluded that the bio-scouring step shows good performance in terms of desizing and scouring in low temperature treatment. Both hydrophilicity and residual pectin content are better than standard pre-treatment of Tov Fiocco Cotone. The bleaching-step needs further improvement to obtain the required whiteness. Low temperature rinsing has no influence on the poor whiteness of the fabric, because the residual $\mathrm{H}_{2} \mathrm{O}_{2}$ is determined after the bleachingsteamer and before the rinsing compartments. Further optimization of the bleaching step is necessary.

\subsubsection{Fabric 2: Tela Cotone}

The following samples of the fabric Tela Cotone have been collected and evaluated:

8. greige fabric Tela Cotone;

9. standard pre-treatment production;

10. trial 4 - first $500 \mathrm{~m}$ of batch $2000 \mathrm{~m}$;

11. trial 5 - last $1000 \mathrm{~m}$ of batch $2000 \mathrm{~m}$.

Based on the poor whiteness of Tov Fiocco Cotone (trial 1 and 2) and the first A-frame Percale Savoy (trial 3 and 4) it has been decided to improve the concentration of the bleaching agents again. Trial 4 has been started with Tela Cotone. After 500 running metres it has been decided to change to trial 5 due to the unsatisfactory whiteness. The concentration $\mathrm{NaOH}$ in the bleaching step was at the start of this batch $5 \mathrm{ml} / \mathrm{l}$ (trial 4) and is increased to $8 \mathrm{ml} / \mathrm{l}$ (trial 5) of the bleaching liquor. At the same time the concentration surfactant is reduced from 4 to $3 \mathrm{ml} / \mathrm{l}$. This is only done for this fabric, because it is believed that the openness of this woven fabric allows reduction of the concentration detergent. The evaluation of the samples Tela Cotone is reported in table 6.7 . 


\begin{tabular}{|l|c|c|c|c|}
\hline Tela Cotone & greige & standard & $\begin{array}{c}\text { trial 4 } \\
\text { sample 10 }\end{array}$ & $\begin{array}{c}\text { trial 5 } \\
\text { sample 11 }\end{array}$ \\
\hline Degree of whiteness (Cie/D65) & - & 71 & 63 & 60 \\
\hline -basic & 2893 & 2253 & 2469 & 2493 \\
\hline Indication of damage & - & 0.26 & 0.16 & 0.15 \\
\hline -DP-value & starch & 7 & $5-6$ & 6 \\
\hline -S-factor & - & - & - & - \\
-TEsizing & - & 4 & 8 & 7 \\
- PVA presence & - & 30 & 32 & 32 \\
\hline Hydrophilicity & - & 30 & 28 & 28 \\
\hline -Time (s) & 100 & 47 & 38 & 37 \\
-Warp (mm) & & & & \\
\hline -Weft (mm) & & & & \\
\hline Pectin content (Ruthenium red test) & - Colourstrength (\% vs. greige 100\%) & & & \\
\hline
\end{tabular}

Table 6.7: Evaluation of the pre-treatment of Tela Cotone

The changes in the concentration of the bleaching agents showed no significant improvement of the whiteness of the fabric. Sample 11 even showed a slight decrease of whiteness after simultaneous increase of concentration $\mathrm{NaOH}$ and decrease of the concentration surfactant. The desizing and hydrophilicity of the treated samples is poor when they are compared with standard treatment. It is believed that these performance indicators will improve after optimization of the bleaching step. The residual pectin content is, even with a poor bleaching performance, substantial better than the standard treatment. The samples 12 and 13 have been reprocessed and are not reported here.

It is concluded that the trials with the fabric Tela Cotone need further improvement on all performance aspects.

\subsubsection{Fabric 3: Percale Savoy}

The following samples have been collected after the treatment of the fabric Percale Savoy:

14. Greige fabric Percale Savoy

The samples 15/16/17 are from standard production, dated on 30-05-2007. In column 14/15/16 the average value of these samples that are taken out of the right, mid and left part of the fabric are evaluated.

The samples 18/19/20 are samples that are treated according trial 3 . In the table the average performance value is presented.

The samples 24/25/26 are taken from trial 4.

The samples with the numbers $27 / 28 / 29$ are from trial 7 . The average value of these samples is presented in the table.

The fabric 3, Percale Savoy, is treated in the trials 3, 4 and 7. Based on the performance of the previous treated fabrics it has been decided to increase the concentration $\mathrm{H}_{2} \mathrm{O}_{2}$ to $40 \mathrm{ml} / \mathrm{l}$ bleaching liquor in trial 7 . The concentration surfactant is increased from 3 to $4 \mathrm{ml} / \mathrm{l}$ and $\mathrm{NaOH}$ $48^{\circ} \mathrm{Bé}$ is increased from 8 to $10 \mathrm{ml} / \mathrm{l}$ in trial 6 . In the standard pre-treatment process for Percale 
Savoyat at Satta e Bottelli $50 \mathrm{ml} / / \mathrm{H}_{2} \mathrm{O}_{2} 35 \%$ and $23 \mathrm{ml} / \mathrm{l} \mathrm{NaOH} 48^{\circ}$ Bé is used. Standard treatment of Percale is characterized by the use of high concentrations of detergents, $\mathrm{NaoH}$ and $\mathrm{H}_{2} \mathrm{O}_{2}$ to avoid stain problems due to residual oil from spinning or weaving processes and to realize sufficient whiteness. The evaluation data of the samples Percale are reported in the table 6.8. All samples, except sample 14 , are taken in triplicate at the right, middle and left side of the fabric.

\begin{tabular}{|l|c|c|c|c|c|}
\hline Percale Savoy & $\begin{array}{c}\text { greige } \\
\text { sample 14 }\end{array}$ & $\begin{array}{c}\text { standard } \\
\text { sample } \\
15-16-17\end{array}$ & $\begin{array}{c}\text { trial 3 } \\
\text { sample } \\
18-19-20\end{array}$ & $\begin{array}{c}\text { trial 4 } \\
\text { sample } \\
24-25-26\end{array}$ & $\begin{array}{c}\text { trial 7 } \\
\text { sample } \\
27-26-29\end{array}$ \\
\hline Degree of whiteness (Cie/D65) & - & 75 & 61 & 51 & 58 \\
\hline -basic & 2465 & 2167 & 2294 & 2263 & 2311 \\
\hline Indication of damage & - & 0.16 & 0.08 & 0,10 & 0,08 \\
\hline -DP-value & & & & & \\
-S-factor & starch & $6-7$ & 6 & $5-6$ & 6 \\
\hline Desizing & PVA & - & - & - & - \\
-TEGEWA-value violet scale & $>300$ & 15 & 10 & 11 & 5 \\
- PVA presence & & 35 & 32 & 33 & 32 \\
\hline Hydrophilicity & & 35 & 33 & 34 & 29 \\
-Time (s) & 100 & 37 & 34 & 37 & 35 \\
-Warp (mm) & & & & & \\
-Weft (mm) & & & & \\
\hline Pectin content (Ruthenium red test) & & & & & \\
- Colourstrength (\% vs. greige 100\%) & 100
\end{tabular}

Table 6.8: Evaluation of the samples Percale

The evaluation of the samples $15-17$ shows that the hydrophilicity of standard processing is rather poor. Despite increased concentrations $\mathrm{H}_{2} \mathrm{O}_{2}$ and $\mathrm{NaOH}$ the whiteness is still not on the required level. In the trials 3,4 and 7 it is clear that the enzymatic treatment step shows good performance for residual pectin content and hydrophilicity. The TEGEWA-violet scale value for desizing however is slightly worse than standard. During the treatment in trial 3 it was evident that the decomposition of $\mathrm{H}_{2} \mathrm{O}_{2}$ was not complete (titanylchlorite test), which resulted in the poor whiteness. The samples 24-26 that are treated in trial 4 are processed after adding $5 \mathrm{ml} / \mathrm{l} \mathrm{NaOH}$ $48^{\circ} \mathrm{Be}$ compared to trial 3 . This addition of $\mathrm{NaOH}$ resulted in an even worse whiteness when compared to recipe 3 . It is believed that the stabilizer shows too much buffering capacity, which results in insufficient activation of the decomposition of $\mathrm{H}_{2} \mathrm{O}_{2}$. This is confirmed with the titanylchlorite test, which indicates a high concentration of residual peroxide.

In trial 7 the concentration of $\mathrm{H}_{2} \mathrm{O}_{2}$ is increased, despite the residual peroxide on the fabric after bleaching. Here it is also seen that the increased $\mathrm{H}_{2} \mathrm{O}_{2}$ concentration hardly improves the whiteness of the fabric. This supports the former assumption that the decomposition of $\mathrm{H}_{2} \mathrm{O}_{2}$ is hindered by the strong stabilizing and buffering performance of the stabilizer. The samples taken after reprocessing are numbered $21 / 22 / 23$, but not reported here as reprocessing is beyond the scope of this work. 


\subsubsection{Overall performance of the new pre-treatment process after the first trials}

The overall performance of the new treatment is presented in table 6.9. Here all fabrics are evaluated in terms of 'better than standard', which is marked + and 'worse than standard', which is marked - .

\begin{tabular}{|l|c|c|c|}
\hline Overall performance of the new pre-treatment process \\
\hline & $\begin{array}{l}\text { Fabric 1 } \\
\text { Tov Fiocco cotone }\end{array}$ & $\begin{array}{l}\text { Fabric 2 } \\
\text { Tela cotone }\end{array}$ & $\begin{array}{l}\text { Fabric 3 } \\
\text { Percale Savoy }\end{array}$ \\
\hline degree of whiteness & - & - & - \\
\hline indication of damage & + & + & + \\
\hline desizing & + & - & - \\
\hline hydrophilicity & + & - & + \\
\hline pectin content & + & + & + \\
\hline
\end{tabular}

Table 6.9: Overall evaluation of the new pre-treatment process

The following can be concluded based on the overall evaluation of all trials:

1. the whiteness is insufficient for all trials. It is clear that further improvement of the whiteness is necessary. It is further assumed that the buffering and stabilizing capacity of the stabilizer hinders the activation of $\mathrm{H}_{2} \mathrm{O}_{2}$ for bleaching;

2. the indication of damage is in all trials better than standard. However here it should be taken into account that the DP or the related S-factor might decrease when the bleaching is improved;

3. the desizing performance of the new treatment is less than the standard for fabric 2 and fabric 3. Here it is assumed that there is room for improvement;

4. the hydrophilicity of fabric 2 is less than the standard after the treatment with the enzyme cocktail. In this trial the concentration surfactant is reduced. It is believed that the concentration surfactant that is used in the previous trials will improve the hydrophilicity due to increased emulsifying of the hydrophobic residues;

5. the residual pectin content in all trials is better than standard. This effect is also seen in two dyeing trials, where it is seen that better dye efficiency is realized.

\subsubsection{Evaluation of the wastewater samples}

During treatment also samples of wastewater are taken. The samples are collected from the effluent of the rinsing compartments after enzymatic treatment and the rinsing compartments after bleaching. The wastewater samples are collected at the end of the production batches. The samples that are evaluated are listed in table 6.10. The chemical oxygen demand (COD) value is expressed in $\mathrm{mg} / \mathrm{l}$, according to NEN 6633. To calculate the reduction of the COD-value all samples are related to standard production. 


\begin{tabular}{|l|c|c|c|c|c|c|}
\hline \multicolumn{7}{|c|}{ COD wastewater analysis in $\mathbf{~ m g r} \mathbf{O}_{2} / \mathbf{k g}$ effluent } \\
\hline & $\begin{array}{c}\text { Standard } \\
\text { processing }\end{array}$ & $\begin{array}{c}\text { Fiocco } \\
\text { cotone } \\
\text { Trial 1-2 }\end{array}$ & $\begin{array}{c}\text { Percalle } \\
\text { Savoy } \\
\text { Trial 7 }\end{array}$ & $\begin{array}{c}\text { Percalle } \\
\text { Savoy } \\
\text { Trial 3-4 }\end{array}$ & $\begin{array}{c}\text { Tela } \\
\text { cotone* } \\
\text { Trial 4-5 }\end{array}$ & Average \\
\hline $\begin{array}{l}\text { After desizing } \\
\text { and scouring }\end{array}$ & 8600 & 2870 & 2670 & 6130 & 8870 & 5135 \\
\hline $\begin{array}{l}\text { \% reduction vs } \\
\text { standard desizing }\end{array}$ & 100 & 67 & 69 & 29 & 103 & 40,3 \\
\hline After bleaching & 3470 & 1290 & 3260 & 2400 & 2340 & 2318 \\
\hline $\begin{array}{l}\% \text { of standard } \\
\text { bleaching }\end{array}$ & 100 & 63 & 6 & 31 & 33 & 33,2 \\
\hline
\end{tabular}

Table 6.10: Result of evaluation of water samples taken during processing

* Tela Cotone contains high amounts of starch $(10-12 \%)$.

To calculate the reduction of the COD-value the average value of all samples is calculated. The figures can only be used as an indication of the COD-value. The reason for this is that for detailed evaluation of the COD-value the weight of the fabric and the concentration starch on the fabric has to be taken into account.

The COD analysis of the wastewater indicates that a significant reduction of the COD-value is realized. The average overall reduction of COD of the effluent is $38,3 \%$. These values confirm the expected substantial wastewater reduction as published in EuropaBio 2002 (see chapter 1). The COD-value determination has to be repeated frequently after process optimization.

\subsection{Optimization trials}

Based on the evaluation of the first set of trials at Satta e Bottelli, as described in the previous section, it is decided to continue with optimization trials. The aim of these trials is:

1. optimization of the concentrations in the enzyme cocktail that is used in the first process step;

2. improvement of the bleaching performance.

\subsubsection{Chemicals and process conditions}

Desizing and scouring step

The optimization of the chemicals in the enzymatic step consists of adjustment of the concentrations in the enzyme cocktail and detergent. The changes are reported in table 6.11 , which shows the difference in concentration chemicals between the first and the optimization trials at Satta e Bottelli. 


\begin{tabular}{|l|c|c|}
\hline \multicolumn{3}{|c|}{ Impregnation bath for combined desizing and scouring: } \\
optimization trials \\
\hline Constituents & $\begin{array}{c}\text { Conc. used on } \\
\text { industrial scale: } \\
\text { optimization trials }\end{array}$ & $\begin{array}{c}\text { Conc. used on } \\
\text { industrial scale: } \\
\text { first trial }\end{array}$ \\
\hline amylase & $1.7 \mathrm{~g} / \mathrm{l}$ & $1.5 \mathrm{~g} / \mathrm{l}$ \\
\hline cutinase & $2.25 \mathrm{~g} / \mathrm{l}$ & $5.0 \mathrm{~g} / \mathrm{l}$ \\
\hline pectinase & $1.5 \mathrm{~g} / \mathrm{l}$ & $1.5 \mathrm{~g} / \mathrm{l}$ \\
\hline surfactant & $5.0 \mathrm{~g} / \mathrm{l}$ & $6.0 \mathrm{~g} / \mathrm{l}$ \\
\hline
\end{tabular}

Table 6.11: Comparison of the concentration chemicals of the first and optimized enzymatic step

Based on the evaluation of the previous trials at Satta e Bottelli it has been decided to improve the concentrations of the chemicals. In table 6.11 the concentrations that are used in the experiments are reported. The differences are:

- the concentration amylase is increased with $10 \%$ to improve the desizing performance of the enzyme cocktail;

- the concentration of the enzyme cutinase is reduced with $50 \%$. In the previous trials the concentration cutinase has been increased, when compared with the lab scale experiments, with more than $100 \%$ to proof the principle. As the evaluation of the previous trials showed good wetting properties it has been decided to reduce the concentration cutinase to the reported level;

- the concentration pectinase has not been changed;

- the concentration surfactant is reduced with about $20 \%$. This seems possible due to the good wetting and rinsing properties of the fabrics percale and fiocco cotone after the first trials.

\section{Bleaching step}

After the first trial it is concluded that the whiteness of the fabric is poor and has to be improved. Therefore adjustments are made in the selected bleaching agents and the concentrations that are used. The proposed bleaching agents and their concentrations are reported in table 6.12.

\begin{tabular}{|l|c|c|}
\hline \multicolumn{3}{|c|}{ Impregnation bath for bleaching: optimization trials } \\
\hline Product & $\begin{array}{c}\text { Conc. used on } \\
\text { industrial scale: } \\
\text { optimization trials }\end{array}$ & $\begin{array}{l}\text { Conc. used on } \\
\text { industrial scale: first } \\
\text { trial }\end{array}$ \\
\hline $\mathrm{H}_{2} \mathrm{O}_{2} 35 \%$ & $50.0 \mathrm{ml} / \mathrm{l}$ & $35.0 \mathrm{ml} / \mathrm{l}$ \\
\hline $\mathrm{NaOH} 48^{\circ} \mathrm{Bé}$ & $6.0 \mathrm{ml} / \mathrm{l}$ & $1.0 \mathrm{ml} / \mathrm{l}$ \\
\hline stabilzer & $7.5 \mathrm{ml} / \mathrm{l}$ & $13.5 \mathrm{ml} / \mathrm{l}$ \\
\hline $\begin{array}{l}\text { manganese } \\
\text { catalyst }\end{array}$ & $6.0 \mu \mathrm{mol} / \mathrm{l}$ & - \\
\hline surfactant & $2.5 \mathrm{ml} / \mathrm{l}$ & $3.0 \mathrm{ml} / \mathrm{l}$ \\
\hline
\end{tabular}

Table 6.12: Impregnation bath for optimization trial for bleaching compared with the starting point of the first trial. *The manganese catalyst that has an improved thermostability. 
For bleaching optimization it has been decided to perform the following changes:

- the product Tannex RL 1024A, which is a bleaching stabilizer is replaced by the product Tannex RL 1094 with comparable stabilizing properties, but the latter product has reduced buffering capacity;

- the manganese catalyst is the TanatexChemicals experimental product Tanede RL 1088. This product is introduced as the new manganese catalyst. The chemical basis of this activator is reported to be comparable with the manganese catalyst of the ligand 1,4,7trimethyl-1,4,7-triazacyclononane (MnTACN). This product has an improved thermostability, when it is compared with the manganese catalyst that has been tested in lab scale experiments. Further information on this catalyst is restricted due to an NDA agreement;

- the concentration $\mathrm{NaOH}$ is increased form $1.5 \mathrm{ml} / \mathrm{l}$ to $6 \mathrm{ml} / \mathrm{l}$ to achieve better decomposition of $\mathrm{H}_{2} \mathrm{O}_{2}$;

- the concentration $\mathrm{H}_{2} \mathrm{O}_{2} 35 \%$ is increased to $50 \mathrm{~m} \mathrm{ml} / \mathrm{l}$ to improve whiteness of the fabric up to standard.

\section{Process conditions}

The temperature of the rinsing compartments after the steamer is set at $40^{\circ} \mathrm{C}$. All other process conditions are kept constant.

\subsubsection{Fabrics for the trials}

The fabrics and the quantity that is used for the optimization trials are reported in table 6.13.

\begin{tabular}{|l|c|c|}
\hline & Fabric 1 & Fabric 2 \\
\hline Name & Tela Cotone & Percale Savoy \\
\hline Composition & $100 \%$ Co & $100 \%$ Co \\
\hline Construction & $30 / 30 \times 30 / 30$ & $100 / 2 \times 80 / 2$ \\
\hline Fabric weight $\mathbf{( g / \mathbf { m } ^ { 2 } )}$ & 129 & $120^{*}$ \\
\hline Total length in m & 8000 & 6200 \\
\hline Fabric width in cm & 316 & $305^{*}$ \\
\hline
\end{tabular}

Table 6.13: Fabrics from Satta e Botelli for the optimization trials

* The trials are done with two, well comparable Percale fabrics. The average values for these different percale fabrics are here reported.

\subsubsection{Observations and adjustments during the trials}

The fabrics have been impregnated with the enzyme cocktail and surfactant as reported in table 6.11. After storage during 16 hours the fabrics are rinsed, followed by impregnation with the bleaching liquor. The constituents of the bleaching liquor have been reported in table 6.12. During the treatment of the first batch it has been noticed that there was unsatisfactory improvement in terms of whiteness of the fabric, when compared with the first trials and with the standard pre-treated fabrics. Therefore several changes in the selected chemicals and changes in the concentrations have been carried out. The adjustments are reported in table 6.14. 


\begin{tabular}{|l|c|c|c|c|c|c|c|}
\hline Trial & $\mathbf{1}$ & $\mathbf{2}$ & $\mathbf{3}$ & $\mathbf{4}$ & $\mathbf{5}$ & $\mathbf{6}$ & $\mathbf{7}$ \\
\hline Pad batch BioScouring: & 1.7 & 1.7 & 1.7 & 1.7 & 1.7 & 1.7 & 1. \\
\hline amylase in g/l & 2.25 & 2.25 & 2.25 & 2.25 & 2.25 & 2.25 & 2.25 \\
\hline cutinase in g/l & 1.5 & 1.5 & 1.5 & 1.5 & 1.5 & 1.5 & 1.5 \\
\hline pectinase in g/l & 5.0 & 5.0 & 5.0 & 5.0 & 5.0 & 5.0 & 5.0 \\
\hline surfactant in g/l \\
\hline Pad steam bleaching: \\
\hline $\mathrm{H}_{2} \mathrm{O}_{2} 35 \%$ in ml/l \\
\hline $\mathrm{NaOH} 48^{\circ} \mathrm{Be}$ in ml/l & 50 & 40 & 30 & 30 & 40 & 40 & 40 \\
\hline manganese catalyst in $\mu \mathrm{mol} / \mathrm{l}$ & 6 & 9 & 9 & 9 & 12 & 12 & 12 \\
\hline stabilizer (inorgnic) in ml/l & 6 & 6 & 6 & 30 & 30 & 30 & 6 \\
\hline stabilizer (organic) in $\mathrm{ml} / \mathrm{l}$ & 10 & 10 & 10 & 10 & - & - & - \\
\hline surfactant in ml// & - & - & - & - & 5 & 5 & 5 \\
\hline
\end{tabular}

Table 6.14: Adjustments during the trials to chemicals and the concentrations

During the trials it has been concluded that the improvement of the whiteness would not be realized with the inorganic bleaching stabilizer. Increasing the concentration $\mathrm{NaOH}$ did not result in a higher $\mathrm{pH}$ of the bleaching bath. Here it is assumed that the inorganic stabilizer is too strongly buffering the bleaching bath. This is also confirmed when the concentration $\mathrm{H}_{2} \mathrm{O}_{2}$ has been reduced. Also in this case no change of $\mathrm{pH}$ is measured. Therefore it has been decided to replace this stabilizer by an organic stabilizer.

The drastic increase of the concentration manganese catalyst is done to explore the influence of the catalyst in the system in terms of whiteness. After the statement that this increase of the concentration of the manganese catalyst did not deliver the required degree of whiteness the concentration is reduced to the starting level.

The samples are collected after drying of the fabric by Satta e Bottelli. The sample numbering of Satta e Bottelli is not changed here for traceability reasons.

\subsection{Results of the optimization trials}

\subsubsection{Fabric 1: Tela Cotone}

The following samples have been collected and evaluated:

1. greige fabric Tela Cotone;

2. standard production;

3. trial 1;

4. trial 2;

5. trial 3 .

These samples have been collected after the pre-treatment and drying and have been evaluated at TanatexChemicals. The fabric Tela Cotone is treated according trial 1,2 and 3 as described in table 6.14. The performance of the treatment is reported in table 6.15. The treated samples are compared with the greige fabric (sample 1) and the standard pre-treated fabric (sample 2). Adjustments to the concentrations chemicals in the bleaching bath are done because the whiteness of the fabric was insufficient, as it is clear from the measured degree of whiteness as reported in table 6.15. Also the residual $\mathrm{H}_{2} \mathrm{O}_{2}$ content in the first rinsing compartment after the 
bleaching steamer, which has been tested by staining the fabric with titanyl-chlorite, indicated that the bleaching process was inadequate.

\begin{tabular}{|c|c|c|c|c|c|}
\hline Tela Cotone & greige & standard & trial 1 & trial 2 & trial 3 \\
\hline $\begin{array}{l}\text { Degree of whiteness (Cie/D65) } \\
\text {-basic }\end{array}$ & - & 76 & 68 & 67 & 67 \\
\hline $\begin{array}{l}\text { Indication of damage } \\
\text {-DP-value } \\
\text {-S-factor }\end{array}$ & $\begin{array}{c}2181 \\
-\end{array}$ & $\begin{array}{l}1924 \\
0.17\end{array}$ & $\begin{array}{l}1908 \\
0.18\end{array}$ & $\begin{array}{l}1963 \\
0.14\end{array}$ & $\begin{array}{l}1862 \\
0.21\end{array}$ \\
\hline $\begin{array}{l}\text { Desizing } \\
\text {-TEGEWA-violet scale value } \\
\text { - PVA presence }\end{array}$ & $\begin{array}{l}\text { starch } \\
\text { PVA }\end{array}$ & $\begin{array}{c}8-9 \\
-\end{array}$ & $\begin{array}{c}6-7 \\
-\end{array}$ & $\begin{array}{l}7 \\
-\end{array}$ & $\begin{array}{l}8 \\
-\end{array}$ \\
\hline $\begin{array}{l}\text { Hydrophilicity } \\
\text {-Time }(\mathrm{s}) \\
- \text { Warp }(\mathrm{mm}) \\
\text {-Weft }(\mathrm{mm})\end{array}$ & $\begin{array}{l}- \\
- \\
-\end{array}$ & $\begin{array}{c}2 \\
36 \\
30\end{array}$ & $\begin{array}{c}2 \\
34 \\
32\end{array}$ & $\begin{array}{c}1 \\
32 \\
29\end{array}$ & $\begin{array}{c}1 \\
30 \\
28\end{array}$ \\
\hline $\begin{array}{l}\text { Pectin content (Ruthenium red test) } \\
\text { - Colourstrength (\% vs. greige } 100 \%)\end{array}$ & 100 & 34 & 31 & 30 & 24 \\
\hline
\end{tabular}

Table 6.15: Evaluation of the optimized trials of the pre-treatment of Tela Cotone

The performance indicators of the bio-scouring step show good performance of the enzyme cocktail. The increased concentration amylase resulted in improved desizing performance and the hydrophilicity is better than standard, despite the reduced concentration of the enzyme cutinase. These values confirm the conclusions of the evaluation after the first trials at Satta e Bottelli. The evaluation of the samples shows here no improvement in whiteness of the fabric. It is clear that the increase of $\mathrm{NaOH}$ of $50 \%$ compared to the first trial and the decrease of the concentration $\mathrm{H}_{2} \mathrm{O}_{2}$ in two steps from $50 \mathrm{ml} / \mathrm{l}$ via 40 to $30 \mathrm{ml} / \mathrm{l}$ has given the desired result. The poor DP-value and S-factor of trial 3 are not in line with the evaluation of other samples. The reason for this low DP-value is not known.

\subsubsection{Fabric 2: Percale}

The following samples have been collected and evaluated:

15. greige fabric Percale;

16. trial 4 ;

18. standard;

25. trial 5;

26. trial 6;

27. trial 7 .

The samples have been collected after treatment. The evaluation of the samples is done by TanatexChemicals. The trials are performed with two different percale fabrics with small differences in yarn count and fabric weight. These differences did not influence the measured performance indicators and are therefore not separately reported. 


\begin{tabular}{|c|c|c|c|c|c|c|}
\hline Percale & greige & standard & trial 4 & trial 5 & trial 6 & trial 7 \\
\hline $\begin{array}{l}\text { Degree of whiteness (Cie/D65) } \\
\text {-basic }\end{array}$ & - & 78 & 62 & 67 & 70 & 71 \\
\hline $\begin{array}{l}\text { Indication of damage } \\
\text {-DP-value } \\
\text {-S-factor }\end{array}$ & $\begin{array}{c}2371 \\
-\end{array}$ & $\begin{array}{l}1922 \\
0.26\end{array}$ & $\begin{array}{c}2014 \\
0.20\end{array}$ & $\begin{array}{l}2144 \\
0.12\end{array}$ & $\begin{array}{l}2162 \\
0.11\end{array}$ & $\begin{array}{l}2033 \\
0.19\end{array}$ \\
\hline $\begin{array}{l}\text { Desizing } \\
\text {-TEGEWA-violet scale value } \\
\text { - PVA presence }\end{array}$ & $\begin{array}{l}\text { starch } \\
\text { PVA }\end{array}$ & $\begin{array}{l}9 \\
-\end{array}$ & $\begin{array}{l}7 \\
-\end{array}$ & $\begin{array}{c}6-7 \\
-\end{array}$ & $\begin{array}{l}8 \\
-\end{array}$ & $\begin{array}{l}7 \\
-\end{array}$ \\
\hline $\begin{array}{l}\text { Hydrophilicity } \\
\text {-Time }(\mathrm{s}) \\
- \text { Warp }(\mathrm{mm}) \\
\text {-Weft }(\mathrm{mm})\end{array}$ & $\begin{array}{l}- \\
- \\
-\end{array}$ & $\begin{array}{c}1 \\
30 \\
32\end{array}$ & $\begin{array}{c}4 \\
30 \\
30\end{array}$ & $\begin{array}{c}2 \\
30 \\
30\end{array}$ & $\begin{array}{c}2 \\
30 \\
30\end{array}$ & $\begin{array}{c}2 \\
32 \\
30\end{array}$ \\
\hline $\begin{array}{l}\text { Pectin content (Ruthenium red test) } \\
\text { - Colourstrength }(\% \text { vs. greige } 100 \%)\end{array}$ & 100 & 37 & 40 & 41 & 36 & 44 \\
\hline
\end{tabular}

Table 6.16: Evaluation of the optimized trials of the pre-treatment of Percale

In section 6.8.1 it is reported that the performance indicators for the bio-scouring step show good values for the enzyme cocktail. Although the residual pectin content is higher than the standard treatment, it is within industrial acceptable values. Desizing and hydrophilicy of the treated fabrics are within industrial accepted values. Evaluation of the whiteness shows that a significant improvement occurred when the organic bleaching stabilizer has replaced the inorganic bleaching stabilizer. At the same time the concentration $\mathrm{NaOH}$ is increased from 9 to $12 \mathrm{ml} / \mathrm{l}$. Surprisingly the reduction of the bleach activator in trial 7 did not result to poorer whiteness values of the fabric. This might be caused by the previously increased concentration $\mathrm{NaOH}$. Here it is concluded that the use of the inorganic stabilizer and the increased $\mathrm{NaOH}$ concentration results in an improved whiteness, which is almost up to standard. It is likely that there is room for further improvement of the whiteness of the fabric. This can be argued because there is still a substantial reduction of the concentration of the bleaching agents $\mathrm{H}_{2} \mathrm{O}_{2}$ and $\mathrm{NaOH}$.

\subsubsection{Standard desizing with new developed 'process conditions and bleaching agents'}

During the trials with the new process it was suggested to run a trial without the enzyme cocktail, but instead of that only amylase as conventional desizing agent has been used. The reason for this is to proof the added value of the enzyme cocktail consisting of the enzymes amylase, cutinase and pectinase. Satta e Bottelli granted this experiment for a production run with 1,000 meter fabric. The standard impregnation conditions have been applied. So the temperature of the impregnation bath was $60^{\circ} \mathrm{C}$. After the reaction, during 16 hours storage, of the amylase enzyme the fabric is rinsed at $50^{\circ} \mathrm{C}$ before it is impregnated with the bleaching agents. Here the same products and concentrations have been applied as in trial 7 . The reaction time and temperature in the steamer is 10 minutes at $100^{\circ} \mathrm{C}$, which are the same conditions as the previous trials. After the bleaching the fabric is rinsed at $50^{\circ} \mathrm{C}$. All other process conditions are the same as the previous trials described in this chapter. The evaluation of the trials is reported in table 6.17. Here the tested sample $A$ is compared with the 'standard' for the fabric Tela Cotone. As 'standard' we defined here the fabric that is processed from the same lot as sample $A$, and it has been treated according 'standard' operating conditions and concentrations chemicals, meaning rinse at the boil and high concentrations of $\mathrm{H}_{2} \mathrm{O}_{2}$ and $\mathrm{NaOH}$. 


\begin{tabular}{|l|c|c|}
\hline Tela Cotone & 'standard' & sample A \\
\hline Degree of whiteness (Cie/D65) & 68 & 66 \\
\hline -basic & & 1943 \\
\hline Indication of damage & 2085 & 0,10 \\
\hline -DP-value & 0,06 & 6 \\
-S-factor & $7-8$ & - \\
\hline Desizing & - & 20 \\
-TEGEWA-violet scale value & 2 & 19 \\
- PVA presence & 28 & 19 \\
\hline Hydrophilicity & 26 & 50 \\
\hline -Time (s) & 39 & \\
-Warp (mm) & & \\
-Weft (mm) & & \\
\hline Pectin content (Ruthenium red test) & & \\
\hline - Colourstrength (\% vs. greige 100\%) & & \\
\hline
\end{tabular}

Table 6.17: Evaluation of the standard pre-treatment and the new developed process without cutinase and pectinase

From the evaluation it is clear that the performance indicators for desizing, hydrophilicity and residual pectin content are worse than the standard. Here the standard is defined as treated without the enzymes cutinase and pectinase. Sample A has been treated under the same conditions and with the same bleaching agents and concentrations as sample $A$, but here no cutinase and pectinase has been used. It is evident from this experiment that the performance indicators are not as good as after 'standard' pre-treatment. The whiteness of the fabric is slightly lower and the desizing performance of amylase is not as good as 'standard'. It is believed that in low temperature treatment the enzyme cocktail has a synergetic effect for the desizing performance.

It is clear that the use of cutinase and pectinase in the enzyme cocktail enables the use of ambient rinsing temperatures and supports the reduction of the concentration $\mathrm{NaOH}$ in the bleaching step of the new process.

\subsubsection{Overall performance of the new pre-treatment process}

The overall performance of the new treatment is presented in table 6.18. The same rating is used as in section 6.6.4. The evaluation after the last adjustment in the second set of trials is reported in this table.

\begin{tabular}{|l|c|}
\hline & Fabric \\
\hline degree of whiteness & - \\
\hline indication of damage & + \\
\hline desizing & + \\
\hline hydrophilicity & + \\
\hline pectin content & + \\
\hline
\end{tabular}

Table 6.18: Overall evaluation of the new pre-treatment process

Based on the evaluation of the optimized trials it can be concluded that:

1. the change of bleaching stabilizers, from an inorganic to an organic, and the increased $\mathrm{NaOH}$ concentration shows a significant improvement of the whiteness of the fabric; 
2. the degree of whiteness is almost up to standard. It is believed that there is room for further improvement;

3. the DP value and S-factor, which are indicators for fibre damage, are comparable with standard despite two negative exceptions. It has to be mentioned here that the 'negative' values of the S-factor are still graded as good bleached fabric [Rouette (Ed), 2001];

4. the desizing of the fabric is comparable or slightly poorer than standard. However the general accepted industrial desizing value is 6 or 6-7. All valued samples are at least as good as industrial accepted desizing values;

5. the hydrophilicity has a rating of $2 \mathrm{~s}$, which is characterized as sufficient;

6. the residual pectin content of all samples is within the accepted industrial values. However some samples show higher values.

\subsection{Conclusion}

Three fabrics have been treated according to the new developed process for bio-catalytic desizing and scouring and low-alkali bleaching. Based on the concentrations chemicals and process conditions after the first set of trials it has been concluded that:

1. the enzyme cocktail consisting of amylase, cutinase and pectinase, shows good performance in terms of desizng, hydrophilicity and residual pectin;

2. the bleaching stabilizer is decisive for the bleaching performance. In the evaluation of the samples it is concluded that the inorganic stabilizer stabilizes the chemical reaction too well, resulting in poor whiteness. Also the buffering capacity was too strong. So in future trials the stabilizer will be subject of consideration. The concentrations $\mathrm{H}_{2} \mathrm{O}_{2}$ and $\mathrm{NaOH}$ are reduced with 20 respective $50 \%$, when compared to standard. It is expected that standard whiteness of the fabric can be realized with few adjustments of the concentrations bleaching agents;

3. rinsing at low temperature, $50^{\circ} \mathrm{C}$ instead of $100^{\circ} \mathrm{C}$ in bio-catalytic treatment is possible and gives sufficient clean fabric;

4. it is not possible to bleach at lower reaction temperature. This is caused by equipment restrictions. So here no catalytic bleaching at low temperature is possible;

5. major reduction of energy, water and wastewater pollution load is achievable in the new process.

Based on these conclusions the chemicals and the concentrations have been adjusted before the second set of trials. This led to the treatment as described in table 6.14. Based on the evaluation of the samples that are collected after this treatment it is concluded that:

1. the increased concentration amylase resulted in an improved desizing performance;

2. the reduction of the concentration cutinase did not result in insufficient hydrophilicity;

3. the residual pectin content was for some samples higher than standard, although these samples are classified as 'within industrial acceptable values';

4. the degree of whiteness of the fabric is still not satisfactory. Although the change from an inorganic to an organic stabilizer resulted in major improvement, it is still not up to standard. Here it has to be notified that the concentration $\mathrm{NaOH}$ simultaneously has been increased with the change of the stabilizer. Further optimization is required despite this improvement of the whiteness; 
5. in hot bleach processes the application of the manganese catalyst is still at discussion. Until now the kinetics of the manganese catalyst have not been established in this process.

The experiments also showed that the handle of the fabric is much softer and generally less damage of the cotton after pre-treatment is realized.

Based on the experiments at Satta e Bottelli it is concluded that the use of enzymes makes low temperature treatment possible at industrial level on existing installed base with reduced consumption of water and energy and pollution load of the wastewater. 


\section{References}

Benninger, private communications, September $8^{\text {th }}, 2010$

CHT R. Beitlich GmbH, Tuebingen, "Handbuch fuer die Vorbehandlung", 2006

Rouette, H.K., "Encyclopedia of Textile Finishing", ISBN 3-540-65031-8, Springer Verlag Berlin/Germany, 2001 



\section{Considerations and economics}

In this work the collaboration between universities and industry was the fundament in the development of the new pre-treatment process. The potential role of universities for applied science as the missing link between academic research and industry was evident. The savings of the new process in terms of reduction of water and energy consumption as well as reduction of wastewater pollution are calculated. The effect on the process costs of the new chemicals is discussed but a final value cannot yet be given, as this will depend on the strategy of the supplier of these chemicals. 


\subsection{Introduction}

Companies are nowadays confronted with rapid developments of markets, logistics and social and environmental responsibilities. Moreover these organizations have to supply an even increasing amount of information to the authorities, shareholders, lobbyists and pressure groups. Companies have tried to fulfill all these demands, but this led often to the loss of focus on new product and process development. The textile industry is no exception in this observation. With the lack of management impulses on new product and process developments companies began to reduce the investments in these activities. Finally, however, this will result in a reduction of the size of the company or even closing down. Besides the hesitation from the top management of textile companies to focus on new developments it is also seen that the middle management level is reluctant to evaluate and implement developments in new products and processes. One of the reasons for this reluctance is that many processes in textile industry are not fully explored and known yet. From this lack of knowledge it is easy to explain that there is hesitation for changes, since not all consequences of a change in processing or production can be overseen. Often new developments cannot be fully tested and evaluated on lab- or pilot scale level. This is caused by the impossibility to mimic industrial scale production in a lab. Besides of that, pilot scale equipment is very expensive and for many companies it is not realistic to invest in this type of equipment.

Fortunately an increasing number of textile companies realize that they have to invest in new products and processes for their future survival and prosperity. New developments are decisive for future successes. If such companies decide to invest in new developments it is obvious that with the scarcity of capital for product- and process developments, the chance of failures should be minimized. For successful process- and product development it is necessary to organize the development process with external partners, as it is clear that it is almost not possible for individual textile companies to control the process from idea generation, academic research, implementation research and development and industrial testing. These issues are specially characteristic for small and medium sized enterprises (SME's).

In the present work the collaboration has been organized on two research levels. The first research level is knowledge and know-how based. Here the universities and the chemical supplier worked closely together to investigate the new process. Here the aim was to explore the influence of process conditions and interaction of the chemicals in the sub process steps on the result of the treatment. The second level is that of the industrial implementation of the new process. Here universities and chemical supplier worked closely together with different industries to implement the newly developed process. The focus in this part of the research was the interaction between the chemistry of the new process, equipment and fabrics.

A co-operation between the beneficiaries of the new process has been established. The selection criterion for the co-operation was "who will earn something with the new process". To answer this question the value chain has been drawn in a simplified scheme in figure 7.1 [Bouwhuis et al. 2007]. 


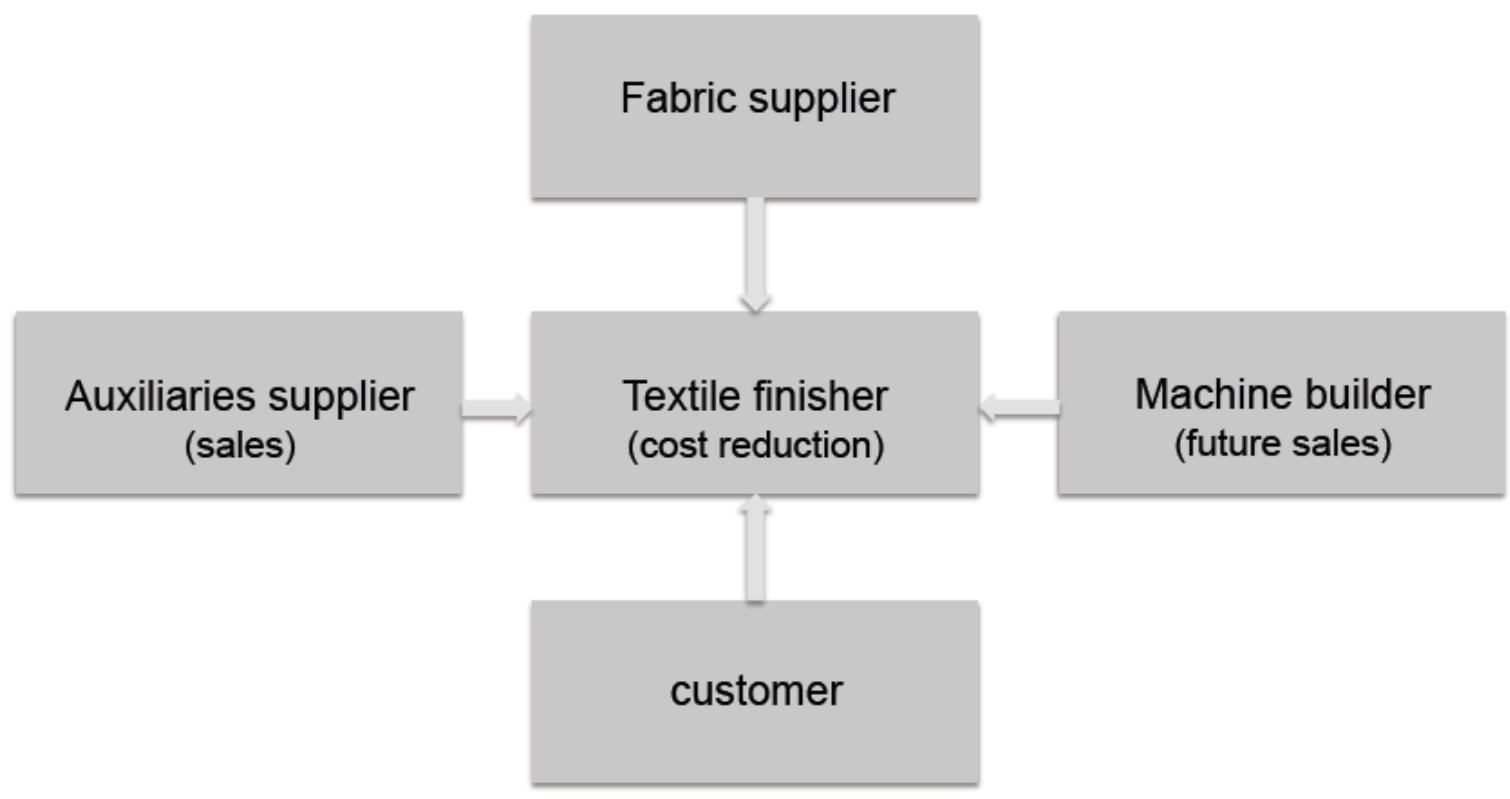

Figure 7.1: Simplified scheme of the position of the partners in the value chain

\subsection{The importance of the value chain and the research funnel}

The question of the beneficiaries of the new process is not difficult looking at figure 7.1. Here the value chain is drawn vertically and the suppliers of the finishing company are drawn horizontally. Based on this scheme the beneficiaries of the new process have been defined:

1. Textile finishing company

The benefits for the textile finishing company are cost savings on the consumption of water and energy and the reduction of the wastewater costs.

2. Auxiliaries supplier

It is expected that new chemicals, compared to the traditional pre-treatment process, will be used. This gives sales opportunities to the auxiliary supplier.

3. Machine manufacturer

It is likely that the new process can be applied on present installed base. Although no direct increase of sales will occur for the machine builder it is likely that this new developed process will lead to improvement of and innovations on installed base for further optimization of this process, resulting in sales opportunities. This is however only expected for future optimization projects.

Based on this knowledge it is clear that successful implementation of the new process depends on co-operation of the finisher and the auxiliaries supplier. The role of the auxiliaries supplier is to explore and prepare the new products for implementation in textile companies i.e. industry. In this case the development finds its origin in academic research. The newly developed know-how has to be implemented by industry. Before implementation it is often necessary to 'transform' academic know-how in industrially applicable technologies, where especially the interaction 
between chemistry, installed base and process conditions has to be explored. Only this total approach gives better chances for successful implementation. Institutes that operate between universities and industry may do the transition of the academic know-how into industrial applicable processes. Here a clear role can be defined for universities of applied science. The development process from academic knowledge to industrial implementation is schematically drawn in figure 7.2: the research funnel. In this work the following partners were involved:

- TanatexChemicals in Ede in the Netherlands. This partner is a supplier of textile auxiliaries;

- TenCate Advanced Textiles in Nijverdal in the Netherlands. This partner is a finishing company with continuous full width pre-treatment equipment;

- Vlisco in Helmond in the Netherlands. Also this partner is a finishing company. The pretreatment process here is done in rope form.

These partners are all member of the Foundation EFSM, in which organization the industrial partners are united, who support the chair EFSM at the University of Twente.

THE RESEARCH FUNNEL

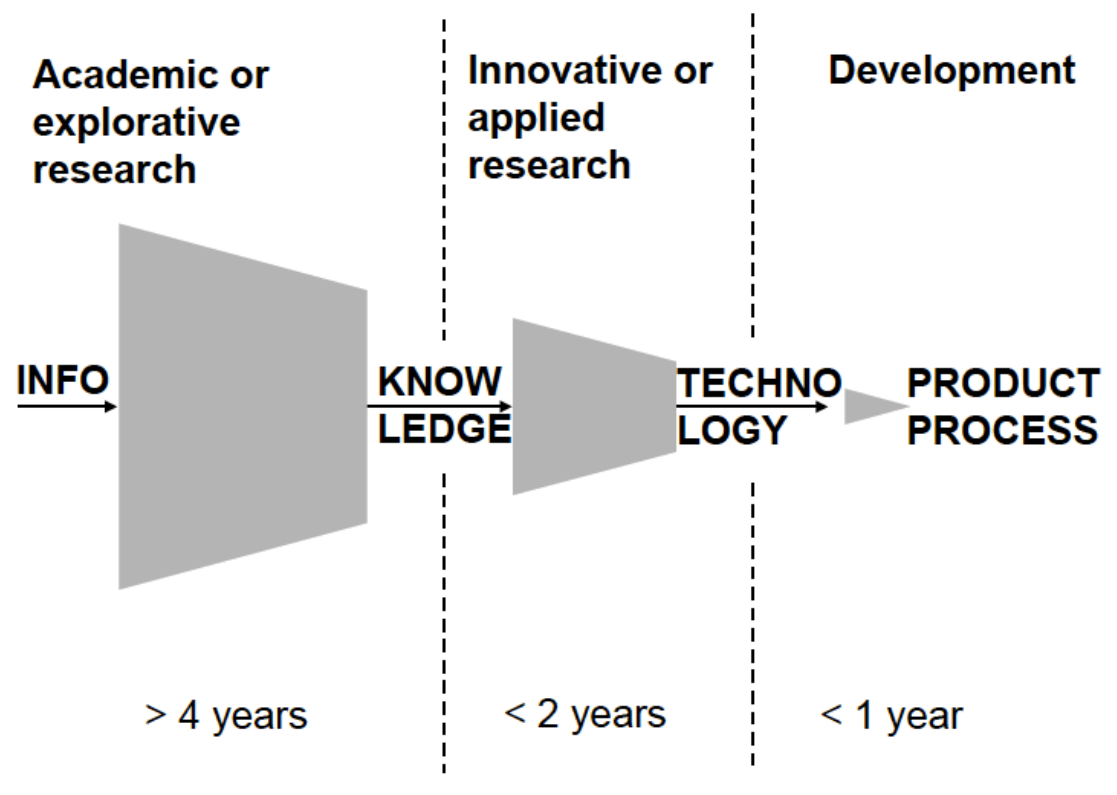

Figure 7.2: The research funnel (McKinsey)

From figure 7.2 it is clear that the development of academic knowledge is long-term research. The research at universities for applied science is medium term research that should deliver the required technology. The industry finally does the short-term development work. In this research process from academic research to industrial application there are researchers involved with different focus. To implement a new process, which is developed after academic research, it is necessary to 'translate' the academic knowledge before it can be applied in industry. Saxion University of Applied Science in Enschede in the Netherlands played a key role in the translation of this academic knowledge. 
The new pre-treatment process for cotton is expected to be beneficial in terms of savings on the costs of water and energy and reduction of the wastewater treatment costs. This was an important item for communication during this work to retain the momentum.

\subsection{Financial evaluation on cost reduction of water, energy and wastewater}

During the last years a lot of information on process cost in pre-treatment in various companies has been gained. All this information is incorporated in a 'model' pre-treatment company. This hypothetical company produces on a weekly basis 500,000 running metres in a specific $100 \%$ cotton fabric. The production activity is pre-treatment and is concentrated on one single production line. In this work we have concluded that the savings on water, wastewater and energy are possible and these are the drivers for the implementation of the new process.

\section{Water consumption}

Savings on water consumption during the rinsing process after bleaching are expected, to be realized after optimization of the new process on industrial scale. Bleaching is done in the new process with low alkali concentration, compared to the conventional pre-treatment. The reduction of alkali is possible, because the degradation of pectines in the primary wall of cotton is already realized in the bio-scouring step. This makes a substantial reduction of $\mathrm{NaOH}$ in the bleaching treatment possible, which allows less intensive rinsing after bleaching. Until now almost $10 \%$ water reduction has been realized and this has been used in the savings calculation. The expected ultimate water reduction in this process step is $20 \%$. In the desizing and bio-scouring step it has been expected that the water consumption could increase because in this effluent now contains also the degradation products of the wax and pectin. Industrial tests however showed that it was not necessary to increase the water flow in the rinsing compartments after this process step. In the financial evaluation the cost of water are expressed in costs per $\mathrm{m}^{3}$ industrial water.

\section{Energy consumption}

The consumption of energy is decreased substantially. Temperatures in the rinsing compartments decreased from 95 to $50^{\circ} \mathrm{C}$ and a further reduction of the rinsing temperature, even down to $30^{\circ} \mathrm{C}$, seems to be possible. No energy reduction is realized in the steamer. The conditions for the impregnated fabric in a steamer are $100 \%$ relative humidity at $100^{\circ} \mathrm{C}$. Without additional capital investment it is not possible to explore incubation conditions in a steamer below $100^{\circ} \mathrm{C}$. Under these conditions there is a high risk of condensation spots on the treated fabric, which can be seen only after dyeing. If the temperature in the steamer could be decreased this would result in smaller cost savings compared to the cost savings realized by reduction of the rinsing temperature. This can be understood from the fact that the water content per $\mathrm{kg}$ fabric that is impregnated with the bleaching chemicals is only a fraction of the water quantity per $\mathrm{kg}$ fabric that is needed for rinsing. Therefore the energy savings are only calculated for energy reduction that is realized in the rinsing processes. To calculate the energy cost reduction the cost price of natural gas has been used based on the following reasoning.

Climate change and greenhouse effects are important subjects. Therefore international conferences have been organized, where targets and regulations for Climate Change prevention 
were announced. The leading organization in these discussions and regulations is the United Nations organization. The ultimate objective of the United Nations Framework Convention on Climate Change (UNFCCC) is stabilization of Greenhouse Gas concentrations in the atmosphere at a level that would prevent dangerous anthropogenic interference with the climate system. The Kyoto Protocol is an international agreement that is linked to the UNFCCC. The major feature of the Kyoto Protocol is that it sets binding targets for 37 industrialized countries and the European Community for reducing Greenhouse Gas $\left(\mathrm{GHG}=\mathrm{CO}_{2}\right)$ emissions. Over the five-year period 2008 - 2012 an average reduction of $5 \%$ against the 1990 level is targeted [UNFCCC 2010]. Countries that have agreed the Kyoto-treaty must meet their targets primarily through national measures. However the Kyoto protocol offers the countries additional means to meet their targets. The most well known mechanism is "Emissions Trading". This system is adopted in Europe since January $1^{\text {st }}, 2005$. In this system organizations get greenhouse gas emission rights assigned. The emission rights have a direct relation to their consumption of natural gas [Agentschap.nl, the former Senter Noven, 2010]. To reduce the emission of Greenhouse Gas a tax has been introduced that is added to the price of natural gas at the amount of $€ 0.029 / \mathrm{Nm}^{3}$ [Kamphuis, 2010]. The target of this emission right is to encourage the reduction of the consumption of Natural Gas. The Greenhouse Gas effect is separately calculated in the cost savings calculation.

\section{Reduction of the pollution of wastewater}

For the quantification of the pollution load of an effluent the COD-value (Chemical Oxygen Demand) of that effluent is used. The COD-value is usually taken as the summation parameter for the organic loading of the effluent and used as a limiting value for permitted discharge and also as a measurement for calculating effluent charges [Rouette (Ed.), 2001]. In this work the COD-value has been used to calculate the savings of the new process. Samples of effluent are collected at the hosting company Satta e Bottelli after the rinse of the bio-scouring and bleaching step. These values are compared with samples that have been taken during conventional treatment prior to the trials. The average decrease of the COD-value is $38 \%$ (see also $\S 6.6$ ). The COD-value decreased from 12.070 to $7.543 \mathrm{mg} \mathrm{O} / \mathrm{kg}$ effluent. So here a decrease of CODvalue is realized of $4.427 \mathrm{mg} \mathrm{O}_{2} / \mathrm{kg}$ effluent. This value will be used in the financial evaluation of the new process. To calculate the costs of wastewater the term pollution unit is introduced here. This pollution unit (PU) is calculated with formula [7.1], which is also used in industry as a simplified calculation model [Stoop, 2003; Gooijer, 2010]:

$$
P U=\frac{Q_{d}}{150}(C O D+4.57 N k j)
$$

in which $Q_{d}$ is the average wastewater flow in $\mathrm{m}^{3}$ per 24 hours, COD is the chemical oxygen demand in $\mathrm{mgr}_{2} / \mathrm{kg}$ effluent, $\mathrm{Nkj}$ is the Nitrogen Kjeldahl value. $\mathrm{Nkj}$ is expressed in gram N/m wastewater effluent [Stoop, 2003]. To convert $1 \mathrm{~g} \mathrm{~N}$ into $\mathrm{NO}_{3}, 4.57 \mathrm{~g} \mathrm{O}_{2}$ has to be used [Gooijer, 2010]. In pre-treatment processes the COD-value is dominating over the Nkj-value and therefore the Nkj-value is not used. To calculate the cost of wastewater the average effluent per twentyfour hours has to be calculated. The average effluent in the pre-treatment department is the daily 
production volume in $\mathrm{kg}$ multiplied with the water consumption per $\mathrm{kg}$ fabric, expressed in $\mathrm{m}^{3}$, corrected for off time for holidays etc. and finally the effluent volume $Q_{d}$ has been found. The Dutch Water Authorities, i.e. Waterschap Regge en Dinkel, make use of a model to find the pollution unit where annually discharge forms the basis. This formula reads:

$$
P U=\frac{Q_{y}(C O D+N k j)}{1000 \times 54,8}
$$

The value $Q_{y}$ is the annual discharge volume (effluent) and the values COD and Nkj are identical to these values in formula [7.1]. The constant 150 in the equation [7.1] is the approximation of the constants in [7.2] divided by 365, being the number of days per year. The constant 1000 is used to convert the COD-value from $\mathrm{mg} / \mathrm{l}$ to $\mathrm{g} / \mathrm{l}$ and the constant 54,8 is the consumption of oxygen for the purification of $1 \mathrm{PU}$ of the wastewater [private communication with Waterschap Regge en Dinkel in the Netherlands].

From the calculation model it is clear that two options can be followed to reduce the costs of wastewater. The first option for reduction of the costs of wastewater is to decrease the CODvalue of the effluent and the second option is to reduce the wastewater effluent. In the new process the COD-value of the wastewater has been reduced, leading to substantial cost savings.

To calculate the cost savings the assumption has been made that there is an imaginary textile company with a weekly production volume of 500,000 running metres full width cotton. The pretreatment process is called pad batch-hot bleach. The installed base that is used for this process has been described in Chapter 2. The process and production data from the imaginary finisher and the physical constants and prices are: 


\begin{tabular}{|c|c|c|}
\hline Product-information and quantities & & \\
\hline - composition & \multicolumn{2}{|l|}{$100 \%$ cotton } \\
\hline - fabric weight & \multicolumn{2}{|l|}{$180 \mathrm{~g} / \mathrm{m}^{2}$} \\
\hline - fabric width & \multicolumn{2}{|l|}{$1.75 \mathrm{~m}^{1}$} \\
\hline - annual production volume in $\mathrm{m}^{1}$ & \multicolumn{2}{|l|}{$23 \times 10^{6} \mathrm{~m}^{1}$} \\
\hline - annual production in $\mathrm{kg}$ & \multicolumn{2}{|l|}{$7.3 \times 10^{6} \mathrm{~kg}$} \\
\hline Process settings & Conventional & bio-catalytic \\
\hline - impregnation temperature with enzymes & $60^{\circ} \mathrm{C}$ & $60^{\circ} \mathrm{C}$ \\
\hline - incubation & room temperature & room temperature \\
\hline - rinse after enzymatic incubation & $6 \mathrm{~kg}$ water/kg fabic & $6 \mathrm{~kg}$ water$/ \mathrm{kg}$ fabric \\
\hline - impregnation temperature with bleaching agent & room temperature & room temperature \\
\hline - incubation in the steamer & $100^{\circ} \mathrm{C}$ & $100^{\circ} \mathrm{C}$ \\
\hline - rinse after bleaching & $6 \mathrm{~kg}$ water $/ \mathrm{kg}$ fabric & $6 \mathrm{~kg}$ water$/ \mathrm{kg}$ fabric \\
\hline - acidification & $1 \mathrm{~kg}$ water $/ \mathrm{kg}$ fabric & $0 \mathrm{~kg}$ water/kg fabric \\
\hline \multicolumn{3}{|l|}{ Data and costs } \\
\hline \multicolumn{3}{|l|}{ - water } \\
\hline density & 1000 & $\mathrm{~kg} / \mathrm{m}^{3}$ \\
\hline heat content & $4.18 \times 10^{3}$ & $\mathrm{~J} / \mathrm{kg} / \mathrm{K}$ \\
\hline cost in $€$ & 0.60 & $/ \mathrm{m}^{3}$ \\
\hline COD-value in $\mathrm{mgr} / \mathrm{liter}$ & 12.070 & 7.543 \\
\hline \multicolumn{3}{|l|}{ - natural gas } \\
\hline combustion value & $31,65 \times 10^{6}$ & $\mathrm{~J} / \mathrm{Nm}^{3}$ \\
\hline cost in $€$ & 0.25 & $/ \mathrm{m}^{3}$ \\
\hline $\mathrm{CO}_{2}$ emission right & 0.029 & $/ \mathrm{Nm}^{3}$ \\
\hline - cost of 1 pollution unit (PU) in $€$ & 50 & /PU \\
\hline
\end{tabular}

Table 7.1 Process and production information of the imaginary finisher

In table 7.1 the process settings of Satta e Bottelli have been used. Further the reduction of water and energy consumption as well as the reduction of the wastewater pollution is copied from the former company. The unit-prices of gas, water and PU are estimated after discussion with the partners.

Based on the former assumptions and realized reduction of the consumption of water and energy and the reduced wastewater pollution the following annual savings have been calculated:

\begin{tabular}{lrr} 
Water & $\mathrm{k} €$ & 4 \\
Energy & $\mathrm{k} €$ & 145 \\
Greenhouse Gas emission rights & $\mathrm{k} €$ & 17 \\
Wastewater & $\mathrm{k} €$ & 449 \\
\cline { 2 - 2 } Total annual savings & $\mathbf{k} €$ & $\mathbf{6 1 5}$
\end{tabular}

\subsection{Chemical costs}

The chemicals that are used for conventional pre-treatment of cotton are amylase, detergents, $\mathrm{NaOH}, \mathrm{H}_{2} \mathrm{O}_{2}$, sequestering agents and peroxide stabilizers. The desizing step in the new process has been transformed in a bio-scouring step, where besides the well-known amylase and detergent also the enzymes cutinase and pectinase have been used. This process-step is now optimized concerning the concentrations chemicals and rinsing temperature. Until now the enzyme cutinase that was used in the enzyme cocktail has been produced only in relatively small quantities and therefore the commercial price is rather high. So in the beginning of the 
application of the new process a part of the savings will be used to compensate the increased chemical costs. However it is expected that the cost price for cutinase will decrease with increasing turnover and therewith the cost per meter fabric will decrease.

In the bleaching step it is expected that the quantity $\mathrm{NaOH}$ will drastically be reduced but also a reduction of the concentration $\mathrm{H}_{2} \mathrm{O}_{2}$ as well as the peroxide stabilizer are expected. The sequestering agent and detergent are estimated to be constant. The extra chemical costs in the bleaching process are caused by the use of the manganese catalyst. The use of this catalyst might be necessary for the activation of the decomposition of $\mathrm{H}_{2} \mathrm{O}_{2}$ in low alkaline bleaching conditions.

In conventional pre-treatment processes the cost of chemicals are in the order of magnitude of $€$ 0.065 per $\mathrm{kg}$ fabric. Based on the savings calculation in section 7.3 it is now possible to calculate the maximum cost increase for the chemicals, based on a break-even situation for the finisher. In that case all cost savings would be consumed by the increase of the chemical-costs of the new process. The cost savings of the new process have been calculated in section 7.3 at k€ 615 for a production volume of $7,3 \times 10^{6} \mathrm{~kg}$. This means that the savings are in an order of magnitude of $€ 0.084$ per $\mathrm{kg}$ fabric. So in a break-even situation the chemical costs per $\mathrm{kg}$ fabric of the conventional process can increase with $129 \%$, which is unlikely.

\subsection{Conclusions}

Based on the results of the industrial experiments it is possible to calculate the benefits of biocatalytic pre-treatment in terms of cost reduction. The calculation is based on the realized process conditions at Satta e Bottelli as described in Chapter 6. The cost reduction on water, energy and wastewater reduction are substantial. It is also discussed that the total costs of chemicals will probably rise, but it is unlikely that the extra chemical costs will exceed the savings. This means that the textile finisher can realize major savings after implementing the new process.

It is clear that efficient production facilities are able to save up to $€ 0.084$ per $\mathrm{kg}$ fabric. This means that the -theoretical- global savings for 25 million ton cotton are in an order of magnitude of $€ 2.1$ bln. These savings confirm the savings as it has been postulated at Autex in 2007 [Bouwhuis et al., 2007]. Taking into account that the major part of cotton pre-treatment facilities are not efficient in the consumption of water and energy it is likely that the global savings can be significantly higher. So it can be concluded that the implementation of bio-catalytic pre-treatment processes for cotton are not only environmentally friendly but also improves the profit of textile companies. 


\section{References}

Agentschap NL, the former Senter Novem, www.nlenergieenklimaat.nl Ist time visited October $4^{\text {th }}, 2010$

Bouwhuis, G.H., V.A. Nierstrasz and M.M.C.G. Warmoeskerken, "The use of (bio)catalysts and ultrasound in the pretreatment of cotton: Application on industrial scale as a sustainable process", Proceedings of the 7th AUTEX Conference, Tampere, Finland, 26-28 June 2007

Gooijer, H., private communications, October $1^{\text {st }}, 2010$

Kamphuis, B.,private communications, October $4^{\text {th }}, 2010$

Stoop, M.L.M., "Water management of production systems optimized by environmentally oriented integral chain management: case study of leather manufacturing in developing countries", Technovation 23, p 265 - 278, 2003

UNFCC, home page, http://unfccc.int ,last time visited October $4^{\text {th }}, \mathbf{2 0 1 0}$

Rouette, H.K., "Encyclopedia of Textile Finishing”, ISBN 3-540-65031-8, Springer Verlag Berlin/Germany, 2001 


\section{Concluding remarks and outlook}

In this chapter concluding remarks are presented. During decades researchers have been working to explore the kinetics of catalytic pre-treatment processes. This research formed the basis for this work, where academic research is implemented in a new environmentally friendly pre-treatment process for cotton. Based on the experience in this project some recommendations for collaboration between industrial parties and knowledge institutions are given. 


\subsection{Concluding remarks}

The basis for this work has been the research of Agrawal and Topalovic concerning bio-scouring and catalytic bleaching as described before. Despite the quality of this research it has not led to industrial implementation.

Because industry has not shown interest in the development of this new pre-treatment process it has been decided to initiate the development of the new bio-catalytic pre-treatment process in close cooperation with knowledge institutes and industry. The basis for the collaboration was the notion that to be successful all participants should profit from the results of this work. The benefit for the partners University of Twente and Saxion Universities of Applied Science in this collaboration is the development of new knowledge and knowhow. The benefit for the industrial partners is increasing sales for the supplier of the textile chemicals and for the textile finisher the benefits of a substantial cost reduction.

Based on the interest of the collaborating partners the following starting points have been defined:

1. the new process has to meet at least the conventional process in terms of process performance but also in terms of capacity;

2. capital investment is excluded and therefore this may not form an obstacle for the implementation of the new process. Textile industry is rather conservative and prudent in terms of capital investment for new processes. This constraint led to the decision to strive for development of a new process based on existing equipment but using alternative chemicals/catalysts and adapting the new process conditions;

3. the work is focused on cost savings, while improving sustainability and reducing the load on the environment. The basis for this focus formed the publications by EuropaBio on the expected cost savings by applying enzymes as alternatives for conventional treatment;

4. distribution of the costs of R\&D over the collaborating parties is agreed at the start of the project. Every partner agreed to support the project with knowledge and knowhow exchange with the other members of this collaboration agreement.

The willingness for collaboration based on the fact that all partners have their own interest in the development of this project has been essential for the realization of the new pre-treatment process.

It can be concluded that:

1. collaboration of knowledge institutes and industry is a major success factor for the transformation of academic research into industrial applicable processes;

2. to be successful a transparent agreement between the partners at the very start of the project about responsibilities, costs and benefits should be the basis for collaboration;

3. bio-catalytic pre-treatment of cotton fabrics leads to major cost savings, increased sustainability and important environmental benefits;

4. no capital investment is necessary to implement the new bio-catalytic pre-treatment process of cotton in existing equipment. 


\subsection{Outlook}

Based on the experience with the hosting company Satta e Bottelli it can be concluded that the new process can lead to major savings. The practice at Satta e Bottelli, and at present also experiences with other textile finishing companies, shows that implementation of the new process requires profound knowledge of the interaction of chemicals, process conditions, fabric and equipment. Therefore it is of utmost importance to start to train textile engineers in the implementation of this new process.

Further optimization of the concentrations chemicals and process conditions in the new developed process still has to be done. Differences between textile companies in fabrics to be treated, requirements after processing and installed equipment require adaption and among others intensive support by the supplier of the chemicals. Process intensification is an important option for further improvement of pre-treatment processes. 



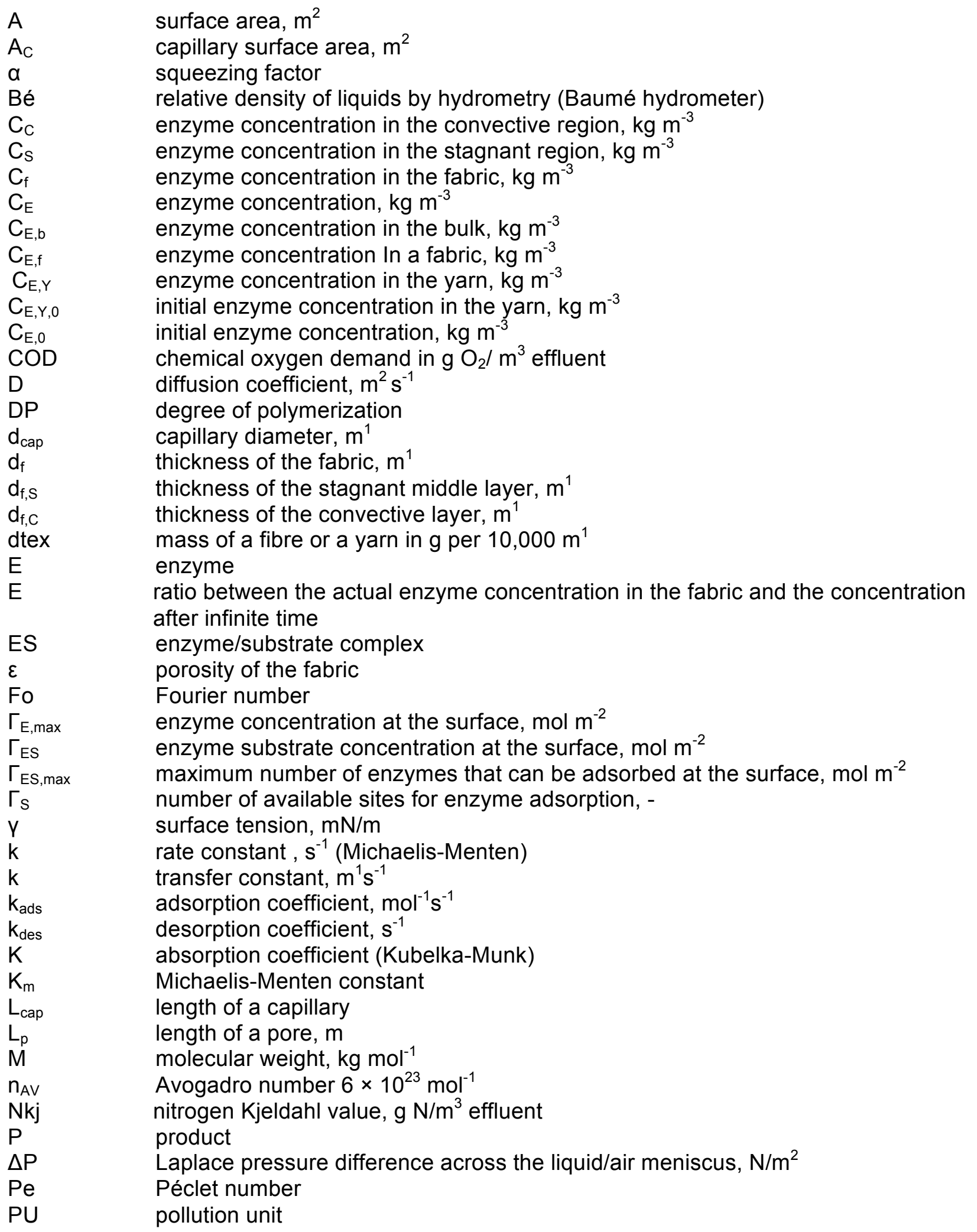




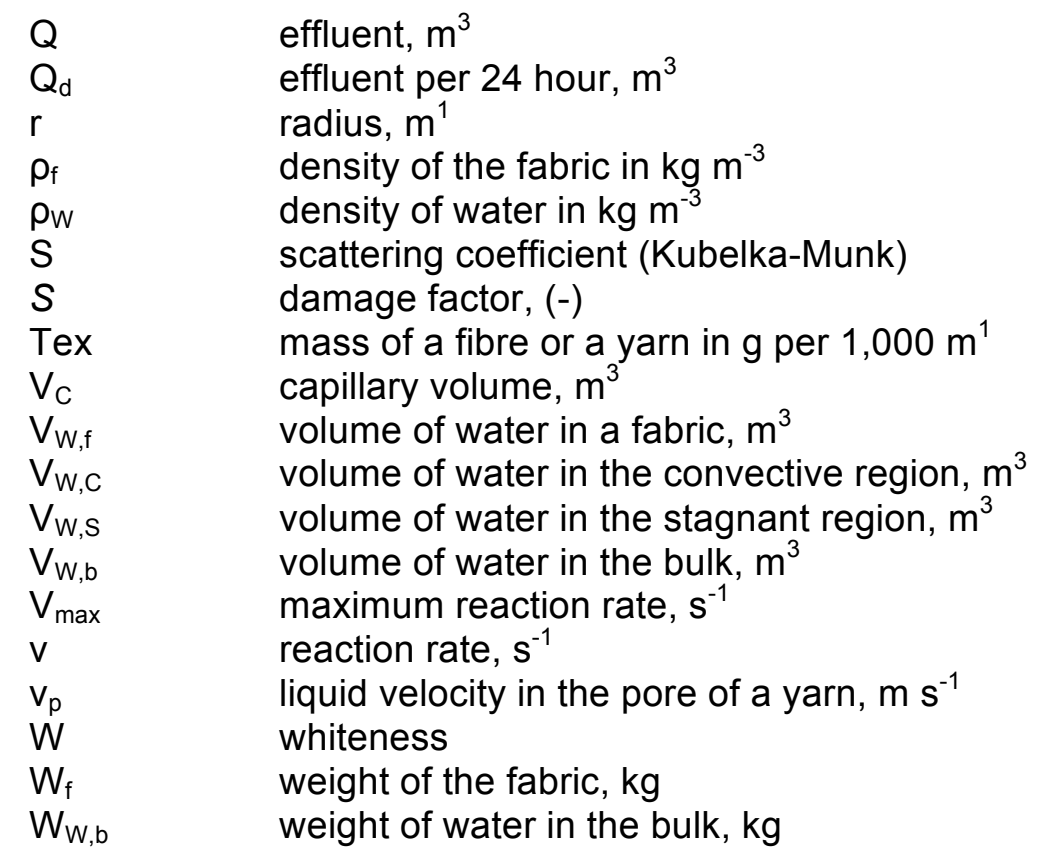




$\begin{array}{ll}\text { AATCC } & \text { American Association for Textile Chemists and Colourists } \\ \text { CIE } & \text { International Commission on Illumination } \\ \text { EDTA } & \begin{array}{l}\text { ethylene diamine tetra-acetic acid } \\ \text { electron paramagnetic resonance }\end{array} \\ \text { EPR } & \text { ElectroSpray lonisation Mass Spectrometry } \\ \text { ESI-MS } & \text { Fourier transform Infrared spectroscopy } \\ \text { FT-IR } & \text { Global Organic Textile Standard } \\ \text { GOTS } & \text { liquor to cloth ratio } \\ \text { LCR } & \text { midden en klein bedrijf } \\ \text { MKB } & \text { dinuclear tri- } \mu \text {-oxo bridged manganes(IV) complex pf the ligand 1, 4, 7-trimethyl- } \\ \text { MnTACN } & 1,4, \text { 7-trazacyclononane } \\ & \text { octylphenol ethoxylates } \\ \text { OPE } & \text { room temperature } \\ \text { RT } & \text { seed coat fragment } \\ \text { SCF } & \text { small and medium enterprises } \\ \text { SME } & \text { tetra acetyl ethylene diamine } \\ \text { TAED } & \text { Textil- und Lederhilfsmittel, Gerbstoff- und Waschrohstoff Industrie } \\ \text { TEGEWA } & \text { Tris(pyridine-2methyl)amine } \\ \text { TPA } & \text { World Wild Fund } \\ \text { WWF } & \end{array}$





\section{Acknowledgement}

This thesis is the result of four and a half year of work. In this period I have been accompanied and supported by many people. It is a great pleasure for me to have the opportunity to express my gratitude to them.

The first person I want to express my gratitude to is my promotor Prof. dr. ir. M.M.C.G. Warmoeskerken. During my research Marijn, as I always called him, was not only supervising my scientific work as a researcher. An important aspect for him was encouraging me to find new options and possibilities to achieve the goals of this thesis. The way Marijn brought up new ideas was very special. There was always a brainstorm or a discussion on the goals of this work, how to realize these goals. These talks were open minded and generated new approaches and strategies to continue the research. The result of these meetings gave a feeling of mutual responsibility and new challenges to work on. In the course of this research we had many discussions on the importance of scientific work for industry and the necessity of academic researchers and industrial developers to work together for real technical, environmental and economical improvements. This way of thinking and focusing on the goals of my work deeply impressed and enriched me.

My co-promotor Prof. dr. ir. W.P.M. van Swaaij deserves my deepest respect in the way we had discussions on textiles and the scientific basis for textile processes. Wim was the person who advised me more than 15 years ago to think about leaving industry and to start working at University of Twente. As Wim always said: 'the entrepreneurial university'. More than once we discussed the importance of scientific and industrial collaboration. In these conversations my interest in research has been induced. At that moment I never expected such a career switch as described before. After the start of my PhD work Wim became my co-promotor. I enjoyed the way we worked together and our discussions during the last four and a half year. Wim transfered his scientific knowledge and experience in a humorous and relaxed way of working closely together with me. I thank you for your advices and the time you always had for me.

I would like to express my gratitude to Dr. ir. V. A Nierstrasz. Vincent was at the start of my research the daily supervisor of the EFSM-group. Due to changes at the University of Twente organization Vincent decided to continue his textile related research in Belgium at the University of Gent. Despite this change of University we always kept good contact. I value the discussions on my work and related issues especially during the last period of my research.

At the start of my research I had the PhD-thesis of Pramod Agrawal and Tatjana Topalovic at my disposal. Their work formed the basis for the research I have done. Moreover the lasting contacts with them and their enthusiasm for my work and the goals we have set made them the two most valuable and loyal supporters that I could get. Thank you both. 
The switch from industry to Saxion University of Applied Science and from there to University of Twente for 2 days per week was not easy. The way of thinking, acting and working was quite different. Thanks to my colleagues at EFSM, I felt at home at University of Twente very soon. The way you all helped and supported me was warm and formed the basis for our friendship. Thank you Dragan Jocic, Ahmit Kulkarni, Audrey Tourette, Simi Bhaskara, Pelagia Glampedaki Jie Zhao, Brigitta Tomcic and Paula Krizman. Last but not least I want to express my gratitude to Mark Schneidermann for his technical assistance in the lab. I will never forget the efforts of the secretary of our chair Yvonne Weber. Thank you all.

Besides these colleagues at EFSM I am very grateful to the bachelor students of Saxion University who assisted with lab experiments. Thank you Bertie Dorgelo, Nils Jongh, Sima Kamseh and Fatima Ozturk for your work, enthusiasm and fun we had together. A special thank you is for Eliza Bottenberg, a graduate student of Textile Management at Saxion University of Apllied Science. Eliza explored the cost savings and presented the cost savings learn-model. Thank you for your work and support.

As mentioned before the switch from textile industry to Saxion was an important change in my career. This turn opened the possibility to use my industrial experience to develop a new environmentally friendly industrial pre-treatment process for cotton. The person who stood at the basis of this switch and who created the conditions to do this research is Jan Wolters, the managing director of the Academy Art, Communication and Technology at Saxion Universities of Applied Science. Jan Wolters has set the pre-conditions for this work together with Ger Brinks and Michiel Scheffer. I owe them a lot of gratitude and thank them for the confidence to charge me with the research and implementation of this project and the never lasting support of Jan Wolters and Ger Brinks and of course of their teams. Special thanks to Ger for the many discussions and advises that were given. These were very valuable and stimulating. It would not have been possible for me to deliver a satisfactory result without the support of my most direct colleagues at Saxion. They were never unwilling to chance lecturing schedules or to take over some of my Saxion-work if the research-work required more time. Uncountable are the request to Annet Dam-Wichers to change once again my schedules. I owe you a great thank you. A special thank is for Petra Grevinga for designing the cover of this book.

The collaboration with industry was important in this work. The company TanatexChemicals played here the beneficial role where an academic researcher only could dream of. Not only the knowhow and lab facilities were put at our disposal, but also the never lasting drive and energy of Rob de Wit. I already valued Rob for his knowledge and drive before we started the collaboration. You were a good partner Rob for discussions on the topics of our work. During the close collaboration I appreciated your contribution even more because of your knowledge and knowhow and I thank you for all the good discussions. Travelling with you and doing the industrial trials together was top-class.

Here it is also important to thank Gerard Emaus from TanatexChemicals. At the very beginning of this project he invited himself and therewith Tanatex to become the selected partner. At that moment it could not be overseen where this research path would end, but he had confidence in the process and outcome of this work. Gerard thank you for this confidence. The colleagues 
from Rob de Wit to be mentioned are Renee Hermse and Johan Kooij. They supported me with the information I requested for. I deeply appreciate their support. Besides the support of TanatexChemicals I have to express my deep gratitude to Royal TenCate in the Netherlands. Here I often had discussions with Tatjana Topalovic, who was always willing to advice and to make time for me. Ton Tijhuis is researcher at Vlisco in Helmond the Netherlands. Ton was an important criticaster for me, but also a fantastic advisor. Thank you both Ton and Tatjana.

In the course of this work I have neglected my friends too much, where they were in fact important supporters. Thank you Egbert \& Andrea, Hans \& Ina, Hans \& Kitty and Will \& Elly. In the scarce moments we had together I sometimes completely lost focus on our common interest and you have all accepted this. I will make it up to you and hope to remain a precious friend as you are for me. In the line of friends there is a special place for Joost and Renee. Joost has successfully finalized his PHD when he was working full time at a gymnasium. He achieved his $\mathrm{PhD}$ also as a part-timer. His experiences and the discussions we had on how to combine and control the work, helped me a lot. I appreciated greatly your advise and support Joost.

My family has played an important role in the realization of this work. Joke thank you for the many discussions on science, social responsibilities and last but not least your never lasting support. My brothers Jan, Joop and Rikke, thank you for your support and sometimes just being there. This meant a lot to me. Thank you Ben Dousi for all the evenings we had for discussions about textiles, technology and improvements. These evenings were valuable.

Very sad is the passing away of my parents in the course of this work. I missed their support and deeply regret that they cannot party with us after the finalizing of my PhD. Paps and mams thank you so much for your love and support you gave to me until the end of your life.

Finally I want to put my daughters Lotte and Eefke and my wife Mieke in the spotlight. They kept on supporting me in my work. Even when I had no time for holidays, or when I had to work during holidays. My absence on parties is notorious. Leaving social events as soon as possible to continue my work. Being busy in finding my way in this research, not spending enough time with them. They did not only accept this behavior, they stayed my best friends and supporters. Despite being often left alone Mieke, Lotte and Eefke actually helped me with my work. Mieke was supervising and always keeping things running and created in this way excellent working conditions. Lotte put a lot of effort in advising me and took care of the lay-out of this book. Eefke and her partner Mischa earn my gratitude for organizing the social events around finalizing my PhD. Thank you Lotte, Eefke \& Mischa and Mieke. I love you.

It is not possible to mention each and everyone who crossed my path and supported me in these exiting years. I thank everybody also those who I forgot to mention. Thank you all very much. 
About the author

Gerhard Herman Bouwhuis was born on March $2^{\text {nd }} 1955$ in Enschede in the Netherlands. After accomplishing the Atheneum education at the Secondary School, Kottenpark College in Enschede in 1975 he started his compulsory military service. To fulfill this duty he served at the Royal Netherlands Marine Corps during 2 years. After 10 months training at the Marine Corps he was sworn in as an officer.

After his military duty he started in 1978 with the bachelor course Textile Management at 'IHBO de Maere', the predecessor of Saxion Universities of Applied Science. In 1982 he finished this course and started his career in the textile industry. In the beginning his jobs were more commercially oriented, but in the course of the following years his work and ambition gradually became more technically directed. During more than ten years he worked at several textile and textile related companies as interim manager. Until 2006 he worked at Royal TenCate as operations manager in the Advanced Textiles Group. In this position he came into contact with academic and industrial researchers. Research and development appealed to him and the necissity came up to decide for either an industrial or an academic continuation of his career.

In 2006 he decided to continue his career at Saxion Universities of Applied Science. Here he was offered the chance to combine lecturing and to work on his PhD project. At Saxion University J. Wolters and ir. G.J. Brinks are his superiors. His research activities are supervised by Prof. dr. ir. M.M.C.G. Warmoeskerken. The result of this research project, titled 'the design of a novel, environmentally improved, industrial cotton pre-treatment process", is presented in this thesis. 
